\title{
Uso de Ferramentas e \\ Tradições Comportamentais em macacos-prego (Cebus spp)
}

\section{Eduardo B. Ottoni}

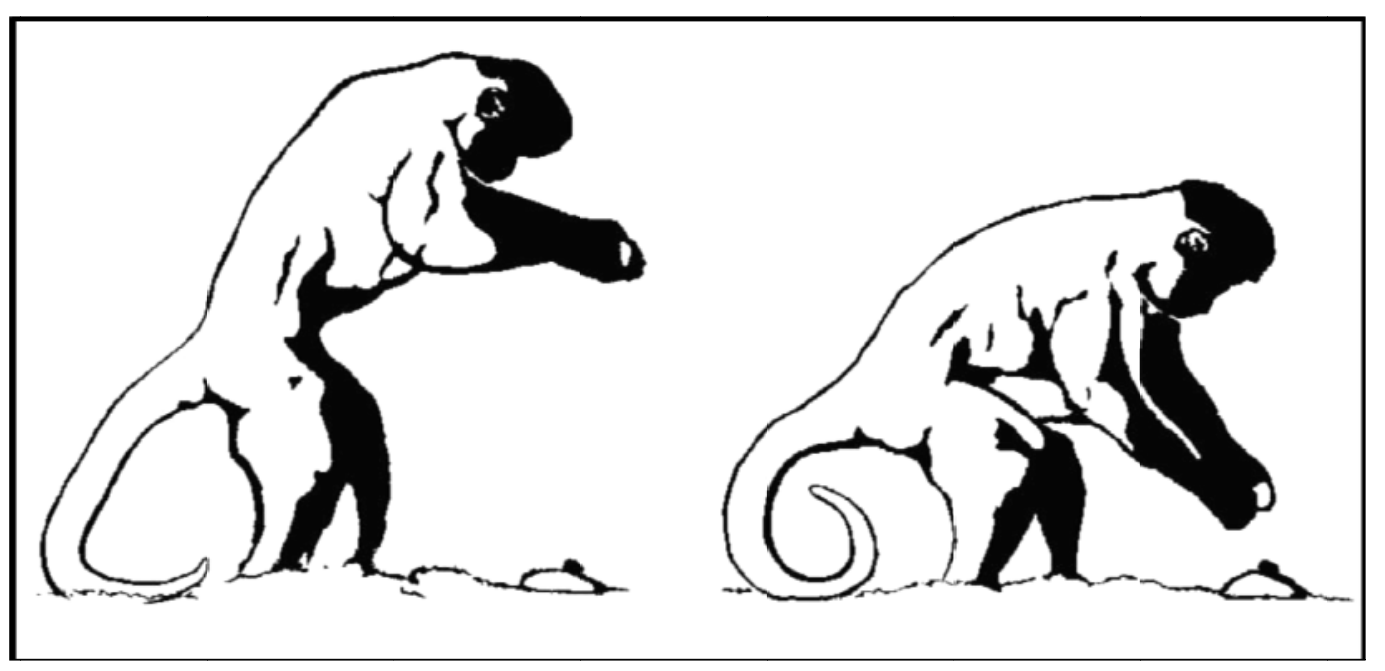

2009 



\title{
Uso de Ferramentas e Tradições Comportamentais em macacos-prego (Cebus spp)
}

\section{Eduardo B. Ottoni}

\author{
Tese de Livre-Docência junto à \\ Área de Conhecimento Etologia
}

Depto. de Psicologia Experimental Instituto de Psicologia Universidade de São Paulo

\section{9}





\title{
Uso de Ferramentas e Tradições Comportamentais em macacos-prego (Cebus spp)
}

\author{
Eduardo B. Ottoni
}

Banca Examinadora 


\section{AUTORIZO A REPRODUÇÃO E DIVULGAÇÃO TOTAL OU PARCIAL DESTE TRABALHO, POR QUALQUER MEIO CONVENCIONAL OU ELETRÔNICO, PARA FINS DE ESTUDO E PESQUISA, DESDE QUE CITADA A FONTE.}

Catalogação na publicação Biblioteca Dante Moreira Leite Instituto de Psicologia da Universidade de São Paulo

Ottoni, Eduardo B.

Uso de ferramentas e tradições comportamentais em macacosprego (Cebus spp) / Eduardo B. Ottoni. -- São Paulo, 2009.

vii+178 p.

Tese (Livre-Docência - Departamento de Psicologia Experimental.) - Instituto de Psicologia da Universidade de São Paulo.

1. Primatas (não humanos) 2. Macacos-prego 3. Aprendizagem social 4. Cultura 5. Tradição comportamental 6. Utilização de ferramentas 7. Cognição (animal) I. Título. 


\section{Agradecimentos e Dedicatória}

TODA a pesquisa aqui relatada é fruto de trabalho em equipe.

Agradeço, de início, a todos os estagiários de graduação que, a partir da Iniciação Científica de Angela Perondi, participaram, ao longo destes 15 anos, do projeto de pesquisa sobre o uso de ferramentas pelos macacos-prego;

Aos pós-graduandos que participam ou participaram do projeto (alguns, agora colegas): Briseida D. Resende - primeira Mestre e Doutora formada sob minha orientação, Criseida Aquino, Renata Ferreira, Michele Verderane, Tiago Falótico, Camila G. Coelho e Eduardo Darvin Ramos da Silva - bem como os que continuarão a pesquisa, como Bianca Oliveira Fonseca e Raphael Cardoso - e aos outros alunos do Laboratório de Etologia Cognitiva, pelas diversas formas de contribuição;

Aos pós-graduandos dos projetos com psitacídeos, Ana Elisa Sestini, Renata Santalla e Andressa Borsari (além da pós-doutoranda Cynthia Schuck-Paim), que me ajudaram a não me esquecer de que o mundo dos animais "inteligentes" não se restringe aos primatas, às alunas que me possibilitaram contribuir de alguma forma para os estudos sobre enriquecimento ambiental e bem-estar animal (Cláudia Hashimoto, Cleide Falcone e Olívia Mendonça Furtado) - e às que não me deixaram deixar completamente de lado as crianças humanas (Janaína C. B. Silva e Cláudia F. Rodriguez);

A Elisabetta Visalberghi e Dorothy Fragaszy, pela honra de poder colaborar com as pesquisadoras que inspiraram o próprio início da nossa pesquisa, e aos colegas brasileiros e estrangeiros com quem estabelecemos parcerias através do projeto EthoCebus;

Às agências de fomento que viabilizaram a pesquisa por meio de bolsas e auxílios, em especial a FAPESP, o CNPq, a CAPES, a National Geographic 
Society e a Leakey Foundation;

À Administração e aos funcionários do Parque Ecológico do Tietê;

À família Oliveira, na Fazenda Boa Vista;

À FUNDHAM (Fundação Museu do Homem Americano) e à Dra. Niède Guidon, pelas inúmeras formas de apoio no Parque Nacional da Serra da Capivara - e ao nosso "mateiro" Francisco "Chico" Reinaldo;

A Francisco "Dida" Mendes e alunos na UCG, pela colaboração e por nossas imperdíveis expedições em Goiás;

A Maria Emília Yamamoto, Maria Lucia Seidl e os demais colegas do projeto de Psicologia Evolucionista do Instituto do Milênio e do GT da ANPEPP, por terem me dado a oportunidade de ajudar a colocar a Psicologia Evolucionista no "mapa" da ciência brasileira;

Aos colegas do Instituto de Psicologia da USP, em geral, e do Departamento de Psicologia Experimental, em particular, pela disposição para a interação interdisciplinar demonstrada ao receber um biólogo em seus quadros e por todos estes anos de trabalho colaborativo - muito especialmente aos etólogos Walter Cunha, César Ades, Emma Otta, Vera Bussab e Fernando Ribeiro, e a Arno Engelmann, de cujo incentivo resultou minha primeira publicação;

Ao Medeiros e ao Juca, por me ajudarem a tentar entender um pouco melhor a minha própria espécie;

A Patrícia Izar, co-autora de tudo o que aqui está, pelos vários anos de intensa e produtiva colaboração;

E finalmente, a Massimo Mannu, aluno e amigo, companheiro dos tempos difíceis do início da pesquisa - mas também de muita risada, pioneiro do Laboratório de Etologia Cognitiva no PET e na Serra da Capivara, que tinha mais é que estar aqui, agora - e a cuja memória dedico esta Tese. 


\section{Sumário}

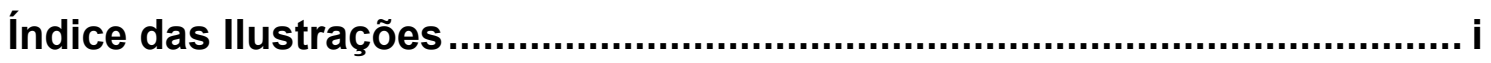

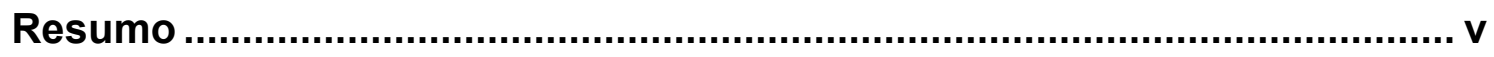

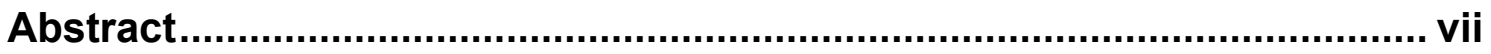

Capítulo 1. Introdução - 0 "chimpanzé do Novo Mundo" ............................. 1

1.1. Uso de ferramentas em animais não-humanos .................................... 2

1.2. Uso de ferramentas em primatas não-humanos .................................... 4

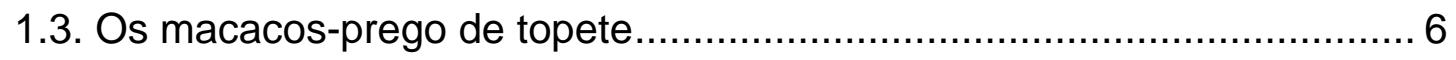

1.4. Capacidades cognitivas dos macacos-prego...................................... 7

1.5. Estudos sobre manipulação de objetos por macacos-prego cativos ..... 10

1.5.1. Uso experimentalmente induzido de ferramentas................................................ 10

1.5.2. Manipulação de objetos e compreensão da causalidade física................................ 11

1.5.3. Experimentos sobre imitação e difusão de comportamentos ……………………... 12

1.6. Primeiras observações naturalísticas de manipulação de objetos......... 14

1.7. A descoberta do uso espontâneo de ferramentas em semi-liberdade ... 17

Capítulo 2. O uso espontâneo de ferramentas em semi-liberdade ............. 19

2.1. O Parque Ecológico do Tietê ............................................................ 20

2.2. O grupo de macacos-prego da Área de Preservação............................. 22

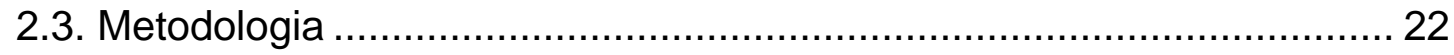

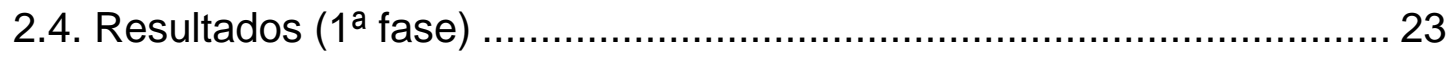

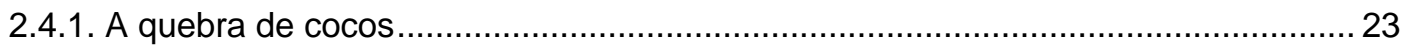




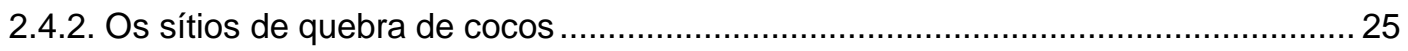

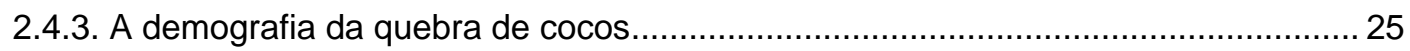

2.4.4. A observação da quebra de cocos por coespecíficos ............................................ 27

2.4.5. A manipulação "inepta" de "martelos" e "bigornas" .................................................... 29

2.5. Segunda fase da coleta de dados .......................................... 30

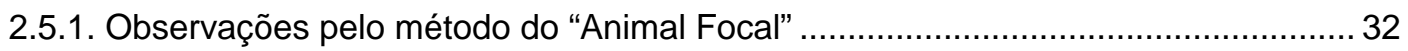

2.6. Constituição e localização dos sítios de quebra ................................ 37

2.7. Terrestrialidade, bipedalismo e transporte de objetos ...................... 38

2.8. Uso de ferramentas pelos macacos-prego do Parque do Jaraguá........ 40

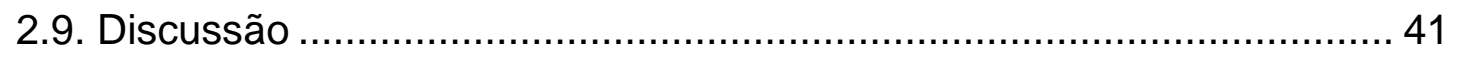

Capítulo 3: O desenvolvimento ontogenético do uso de ferramentas ...... 45

3.1. A ontogênese da quebra de cocos ......................................... 46

3.1.1. A emergência dos níveis de complexidade da manipulação de objetos................... 48

3.2. Influências sociais na aprendizagem ........................................ 50

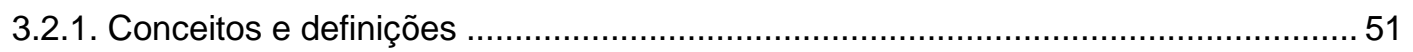

3.2.2. Influências sociais na aprendizagem: estudos em cativeiro .................................. 54

3.2.3. Observação da quebra de cocos por coespecíficos em semi-liberdade................... 57

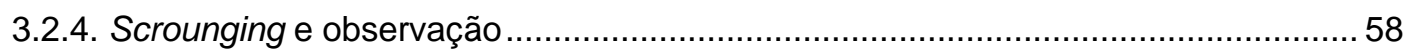

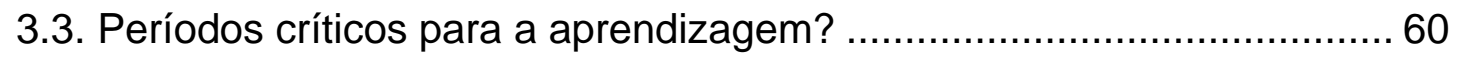

3.4. Scrounging e evolução da tolerância social....................................63

Capítulo 4: Socialidade e uso de ferramentas: brincadeira, "scrounging" e

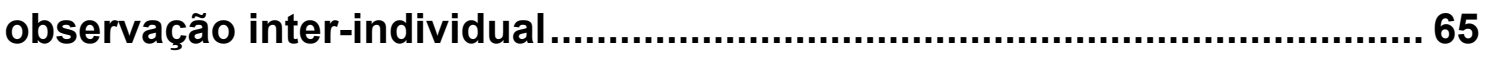

4.1. Proximidade, brincadeira social e observação da atividade dos

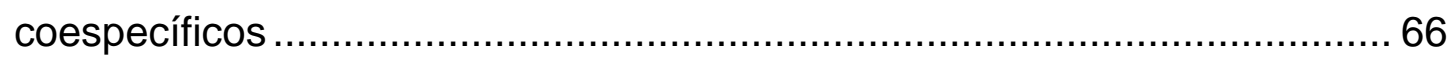

4.1.1. Associação entre brincadeira social e quebra de cocos ....................................... 67

4.1.2. Correlações entre Brincadeira Social, Proximidade e Observação .......................... 68

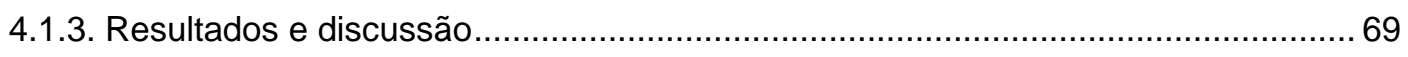

4.2. Reexaminando a escolha dos "alvos" de observação por coespecíficos 71 
4.3. Replicações do estudo sobre escolha dos Alvos de observação com o

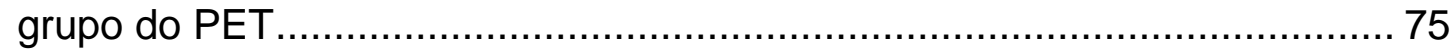

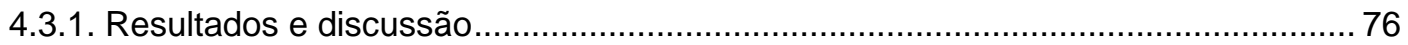

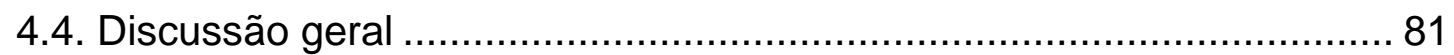

4.4.1. Uma possível história da disseminação do uso de ferramentas no grupo da Área de

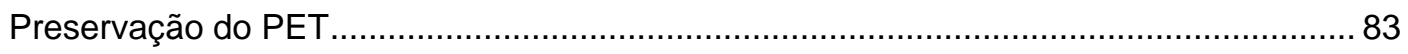

Capítulo 5: O uso de ferramentas por populações selvagens de macacos-

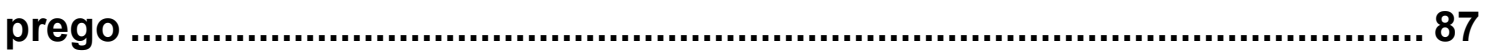

5.1. Os estudos na Fazenda Boa Vista ............................................... 87

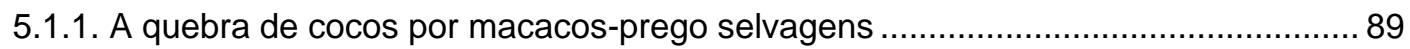

5.1.2. Distribuição de recursos e transporte de ferramentas .............................................. 92

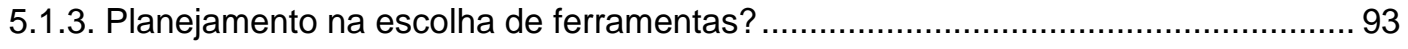

5.2. Primeiro estudo na Serra da Capivara......................................... 93

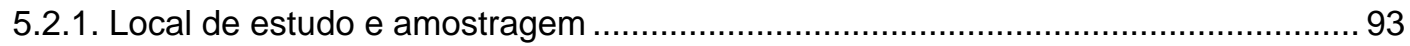

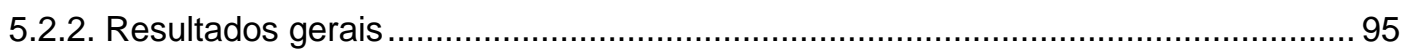

5.2.3 Pedras como ferramentas para quebrar, cavar e cortar .......................................... 96

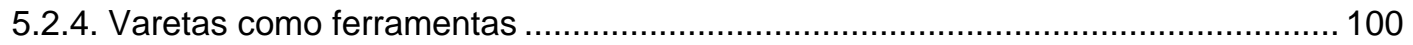

5.2.5. Ferramentas com múltiplas funções................................................................... 103

5.2.6. Uso seqüencial ou associado de duas ferramentas diferentes............................ 103

5.2.7. Observação do uso de ferramentas por coespecíficos ......................................... 105

5.3. Continuidade da pesquisa na Serra da Capivara ............................ 105

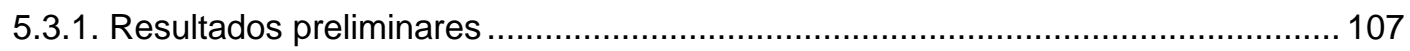

5.4. Diferentes "tool-kits", diferentes tradições?.................................... 109

Capítulo 6: Experimentos de campo ........................................................ 111

6.1. Uso experimentalmente induzido de varetas como sondas............... 112

6.2. Intervenções experimentais no uso de ferramentas para a quebra de frutos encapsulados...................................................................... 114

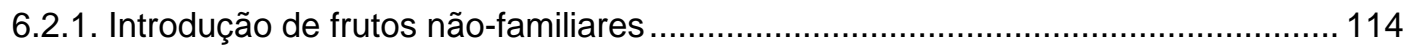

6.2.2. Escolha de "martelos" em função do peso e do tamanho...................................... 117

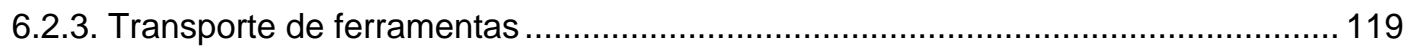


6.3. Escolha de ferramentas adequadas pelos macacos-prego selvagens 121

6.4. Bipedalismo, transporte de ferramentas e planejamento

Capítulo 7. Mapeando o uso espontâneo de ferramentas na natureza: tradições comportamentais em macacos-prego?

7.1. Tradições comportamentais e processos culturais em primatas nãohumanos.

7.2. Determinantes genéticos, ecológicos e sociais da variabilidade comportamental em animais não-humanos .....

7.3. Influência da estrutura e dinâmica social sobre a aprendizagem socialmente enviesada

7.4. Mapeando os relatos de uso de ferramentas pelos macacos-prego ... 134

7.5. Explicações para a variação entre populações no uso de ferramentas137

7.6. Questões e perspectivas

7.6.1. Além do uso de ferramentas

7.7. Implicações para o entendimento da evolução do uso de ferramentas nos hominíneos 143

Referências Bibliográficas 147 


\section{Índice das llustrações}

Figura 1. Sítios de quebra de cocos no Parque Ecológico do Tietê (fotos E.B. Ottoni)........... 19

Figura 2. Área de Preservação do Parque Ecológico do Tietê, São Paulo, SP (Google Earth).

Figura 3. Palmeira e cocos de jerivá, Syagrus romanzofianna (fotos E.B. Ottoni).

Figura 4. Posturas na quebra de cocos (ilustração E.B. Ottoni baseada em vídeo de M. Mannu).

Figura 5. Medeiros posicionando coco para quebrá-lo, num dos primeiros registros filmados do comportamento no PET (vídeo M. Mannu).

Figura 6. Freqüências individuais observadas de quebra de cocos (de Ottoni \& Mannu 2001).

Figura 7. Número médio de episódios de quebra de cocos por indivíduo em cada classe de sexo-idade (de Ottoni \& Mannu 2001). 27

Figura 8. Observadores e "quebradores" observados nas classes etárias (de Ottoni \& Mannu 2001) 28

Figura 9. Proporção de episódios de manipulação inepta de pedras no número total de episódios de manipulação em cada classe etária (de Ottoni \& Mannu 2001)....... 29

Figura 10. Freqüência relativa dos episódios adequados de quebra nos dois períodos de coleta de dados pelo método de "Todas as Ocorrências": total de episódios dividido pelo total de indivíduos de cada classe etária (de Mannu 2002). 30

Figura 11. Freqüência relativa de episódios proficientes de quebra de cocos por faixa etária nos diária nos dois períodos da coleta de dados pelo método de "Todas as Ocorrências" ( $\mathrm{N}$ episódios com consumo de endosperma / total de episódios $\mathrm{X}$ 100) (de Mannu 2002).

Figura 12. Modelos e observadores na quebra de cocos no $2^{\circ}$ período da coleta de dados, pelo método de "Todas as Ocorrências"; total de episódios com observação dividido pelo total de indivíduos em cada faixa etária (de Mannu 2002).

Figura 13. Proficiência média dos indivíduos: total de cocos com o endosperma consumido dividido pelo total de observações focais para cada sujeito (de Mannu 2002)....... 34

Figura 14. Proficiência média dos indivíduos: total de cocos com o endosperma consumido dividido pelo total de episódios adequados para cada sujeito nas observações focais (de Mannu 2002).

Figura 15. Proficiência média dos indivíduos: total de cocos com o endosperma consumido 
dividido pelo total de observações focais, total de episódios adequados e total de episódios proficientes (coco maduro + podre) para cada sexo (de Mannu 2002). . 35

Figura 16. Modelos e observadores na quebra de cocos ("Animal Focal"): totais de episódios de observação de uso de ferramenta (quando o observador ou o modelo são os sujeitos focais) divididos pelo total das observações focais para cada faixa etária (de Mannu 2002). 36

Figura 17. Proporção do tempo gasto na observação de episódios de quebra de cocos; tempo de observação dos episódios dividido pelo tempo total real (descontando o tempo em que o sujeito estava fora da visão do observador) das observações focais para cada faixa etária (de Mannu 2002). 36

Figura 18. Distribuição dos Sítios de Quebra de cocos na Área de Preservação do PET ....... 37

Figura 19. Freqüência absoluta de sítios usados para a quebra de cocos pela distância da palmeira de jerivá mais próxima (Mannu \& Ottoni 2000). 38

Figura 20. Tampa da caixa-problema utilizada em Resende \& Ottoni (2001) na condição de 3 trincos dependentes (que tinham de ser abertos numa determinada ordem - da direita para a esquerda). 56

Figura 21. Eli (manipulador) e Edu, observador e scrounger (foto Humberto Conzo Junior). . 58 Figura 22. X (foto Tiago Falótico) e Z (foto Camila G. Coelho). 62

Figura 23. Localização da Fazenda Boa Vista (A) e do Parque Nacional da Serra da Capivara (B), no Piauí. 88

Figura 24. Chicão (macho dominante) e "scroungers" (Fazenda Boa Vista) (foto T. Falótico).90 Figura 25. Variantes posturais na quebra de $\operatorname{cocos}$ (a, Fazenda Boa Vista; b, PET) (fotos T. Falótico). 91

Figura 26. Boqueirão visto do alto da Serra da Capivara (foto E.B. Ottoni). .94

Figura 27. Quebra de frutos de jatobá, Hymenaea courbaril (vídeo M. Mannu). 97

Figura 28. Buracos escavados com pedras para acessar raízes ou outros órgãos vegetais subterrâneos. Esquerda: tubérculo de Combretum cf. sp.; centro: raíz de aroeira (Astronium cf sp.); direita: tubérculo de batata-de-umbu (Spondias tuberosa) (fotos M. Mannu). 98

Figura 29. Escavação com o auxílio de pedras, usadas como "martelo" e como "enxada" (vídeo M. Mannu) .98

Figura 30. Conglomerado de rocha sedimentar com seixos de quartzo incrustados (foto E.B. Ottoni) .99

Figura 31. Uso de vareta como sonda por um macho subadulto (foto T. Falótico) 100

Figura 32. Exemplos de varetas usadas para acessar mel, cera, invertebrados ou água (foto E.B. Ottoni). 101

Figura 33. Uso seqüencial de uma pedra (para quebrar um tronco podre) e uma vareta (para um ninho de inseto no interior do tronco) (vídeo M. Mannu).

Figura 34. Macho adulto usando um "martelo" de pedra para quebrar uma semente de grãode-galo (Cordia rufescens) (foto T. Falótico). 108 
Figura 35. Macho subadulto do grupo do Bocão cavando com ferramenta de pedra (foto T.

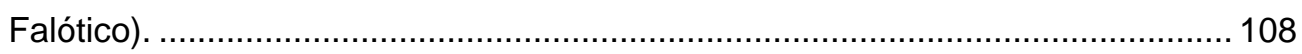

Figura 36. Quinzinho e "scrounger" no aparato experimental (vídeo C. Aquino).................... 112

Figura 37. Sítio experimental (com os "martelos" do segundo experimento) (foto T. Falótico). 115

Figura 38. "Martelos" de granito fornecidos junto às bigornas no segundo experimento, pesando $300 \mathrm{~g}, 600 \mathrm{~g}, 900 \mathrm{~g}, 1300 \mathrm{~g}$ e $1700 \mathrm{~g}$ (foto T. Falótico).

Figura 39. Distribuição das escolhas dos "martelos" em função do peso/tamanho (esquerda: juvenis; direita: adultos/subadultos) (Falótico 2006).

Figura 40. Bipedalismo na manipulação exploratória (a) e no transporte de ferramentas (b,c) (PET; a: foto B.D. Resende; b, c: fotos T. Falótico) 124

Figura 41. Distribuição de registros de uso espontâneo de ferramentas por macacos-prego selvagens e semi-livres. 135

Figura 42. Localização do Parque Nacional da Serra das Confusões (C), entre a Fazenda Boa Vista (A) e a Serra da Capivara (B). 142 



\section{Resumo}

Por cerca de quinze anos, estudamos o uso espontâneo de ferramentas por macacos-prego de topete (Cebus $\mathrm{sp}$ ) semi-livres e, durante os últimos seis, também por populações selvagens no Centro-Oeste e no Nordeste do Brasil. Os estudos com o grupo semi-livre nos possibilitaram descrever, pela primeira vez, a ocorrência de comportamentos de uso de ferramentas numa espécie de macaco do Novo Mundo fora do cativeiro, examinar sua demografia e acompanhar o desenvolvimento ontogenético da quebra de cocos com o auxílio de pedras, investigando as interações entre a dinâmica social e as oportunidades para a aprendizagem socialmente mediada. Os estudos com os grupos selvagens nos permitiram ampliar nossa compreensão sobre o provável contexto ambiental da evolução do uso de ferramentas pelos macacos-prego, ambientes de savana como o cerrado e a caatinga, altamente sazonais e onde alimentos encapsulados de difícil acesso podem ter feito uma diferença crítica enquanto recursos "emergenciais" - para aqueles capazes de processá-los. E a partir de nossas pesquisas e levantamentos, bem como da acumulação de relatos na literatura, vem emergindo um retrato mais amplo do uso de ferramentas nas diversas populações de macacos-prego. Entre as populações de floresta, não há relatos de uso de ferramentas, embora haja instâncias de manipulação complexa de objetos e uso do substrato para abrir alimento encapsulado. $\mathrm{O}$ uso de pedras para abrir frutos encapsulados é a forma mais comum de uso de ferramentas nestas espécies, o único padrão "universal" entre os macacos-prego que usam ferramentas. Mas ao menos em alguns grupos da Serra da Capivara (Piauí), outros tipos de ferramentas (pedras para cavar e varetas como sondas) são utilizadas. As evidências não parecem apontar para diferenças cognitivas entre as espécies de macacos-prego de topete, nem favorecer pressões dietárias como determinantes proximais do uso 
de ferramentas, que parece estar mais relacionado ao grau de terrestrialidade. As diferenças entre populações quanto aos "tool-kits" ("repertórios de ferramentas"), juntamente com nosso conhecimento, baseado nos estudos ontogenéticos, sobre as condições otimizadas para a transmissão social de informação nos grupos sociais de macacos-prego, sugerem que o uso de ferramentas seja uma tradição comportamental. Em sua condição de macacos dotados de grandes cérebros, vivendo numa sociedade tolerante $\mathrm{e}$ dependendo (ao menos em algum momento de sua história evolutiva) de alimentos de difícil processamento, os macacos-prego confirmaram certas previsões teóricas sobre a emergência de tradições tecnológicas em animais não-humanos. Estando separados da linhagem de pongídeos e humanos por cerca de 35 milhões de anos, o estudo do uso de ferramentas pelos macacosprego pode contribuir para o entendimento de muitos aspectos da evolução da tecnologia e da cultura humanas. 
For about fifteen years, we studied the spontaneous use of tools by semi-free tufted capuchin monkeys (Cebus sp), and during the last six, also by wild populations in two locations in Northeastern Brazil. The semi-free studies allowed us to describe for the first time the occurrence of tool using behaviors in a New World monkey species outside captivity, to examine its demography and follow the ontogeny of stone-aided nut cracking, examining the interactions between the social dynamics and the opportunities for socially biased learning. Wild studies allowed us to expand our understanding of the probable environmental context of tool use evolution in capuchin monkeys, savanna-like environments such as the cerrado and the caatinga, highly seasonal and where hard-to-access encapsulated food can make a difference as a fallback resource - for those who can get it. And from our studies and surveys, as well as from the growing reports in the literature, a broader picture of tool use across tufted capuchin populations is emerging. Among forest populations, there are no reports of tool use, though there are instances of complex object manipulation and use of the substrate to open encapsulated food. The use of stones for cracking encapsulated fruit is the commonest form of tool use in these species, the only "universal" pattern among tool-using capuchins. At least in some groups in the Serra da Capivara National Park (Piauí, Brazil), though, other kinds of tools (digging stones and probing sticks) are employed. The evidence so far does not point to cognitive differences between the species of tufted capuchins, nor favor dietary pressures as proximal determinants of tool use, which seems to be primarily associated to the degree of terrestriality. The apparent differences between populations in tool-kits' diversity, along with our knowledge, from the developmental studies, about the optimal conditions for social information transfer in capuchins' social groups, suggest that the use of 
tools constitutes a behavioral tradition. As big-brained monkeys living in a tolerant society and depending (at least at some point in their evolutionary history) on hard-to-process food, capuchins fulfilled some theoretical predictions about the emergence of tool use traditions in non-human animals. Being separated from apes and humans for about 35 million years, the study of tool use in tufted capuchin monkeys may contribute to put many aspects of the evolution of human technology and culture under a new light. 
Macunaíma seguiu caminho. Légua e meia adiante estava um macaco mono comendo coquinho baguaçu. Pegava no coquinho, botava no vão das pernas junto com uma pedra, apertava e juque! a fruta quebrava.

Mário de Andrade, Macunaíma (1928) 



\section{Capítulo 1. Introdução - O "chimpanzé do Novo Mundo"}

Para os interessados na evolução da cognição humana, os chimpanzés e bonobos (Pan troglodytes e $P$. paniscus), inevitavelmente, tem um quê de "elos perdidos". Sua condição de espécies contemporâneas mais próximas de nós, com um ancestral comum há "apenas" seis milhões de anos, e uma similaridade de mais de $88 \%$ entre os genomas, coloca os paníneos - e em certo grau, os outros hominóides e os demais primatas - numa posição muito especial em nossa ciência e nosso imaginário.

Os bonobos chegaram à ciência e à "fama" na mídia recentemente; reconhecidos como sub-espécie, inicialmente, e mais adiante como espécie distinta dentro do gênero Pan, sua vida social mais "relaxada" e altamente sexualizada ofereceu um contraponto interessante à socialidade "machista" e belicosa dos chimpanzés.

A diversidade e complexidade da vida social dos hominóides só se tornou conhecida a partir do estabelecimento de estudos de campo de longa duração, na segunda metade do Século XX. Já as capacidades cognitivas individuais dos chimpanzés eram bastante familiares dos antropólogos físicos e psicólogos comparativos, e tornaram-se clássicas as imagens dos sujeitos de Köhler (1925) resolvendo problemas com o uso de objetos.

Em conformidade com o espírito antropocentrista da Psicologia Comparativa "clássica", os estudos com chimpanzés buscaram acessar, fundamentalmente, aquelas capacidades consideradas como "marcos" da evolução cognitiva humana (ainda que, freqüentemente, para "relativizá-los"). Este é o caso, por exemplo, dos estudos sobre o auto-reconhecimento ao espelho (Gallup 1970, Povinelli 1993, Povinelli et al 1997), que levaram anos de replicações e refinamentos metodológicos para serem amplamente aceitos, e também das pesquisas sobre o uso experimentalmente induzido de 
linguagens simbólicas (Premack \& Premack 1983, Gardner, Gardner \& van Cantfort 1989, Fouts 1997, Savage-Rumbaugh \& Lewin 1994).

Mas foi a partir das observações de Jane Goodall (1990), ao longo de décadas de acompanhamento de uma população de chimpanzés selvagens em Gombe (Tanzânia) que emergiu um quadro inesperadamente complexo sobre a socialidade e sobre as capacidades cognitivas desta espécie em seu ambiente natural: os chimpanzés se mostraram envolvidos em longas escaramuças "políticas" em um cenário de contínua luta pelo poder, capazes tanto de gestos "humanitários", como adoções e consolo, quanto brutais, como infanticídios, assassinatos em série e guerras com os vizinhos. Mais tarde, muito desta complexidade social pode ser examinada em detalhe em grupos cativos (de Waal 1982, 1989). As descobertas sobre a complexidade da vida social dos chimpanzés (e dos demais primatas) levaram a uma revolução nas teorias sobre a evolução das capacidades intelectuais de primatas humanos e nãohumanos, favorecendo modelos aonde as capacidades cognitivas empregadas na manipulação das relações sociais passaram a parecer mais importantes que aquelas selecionadas para se lidar com o ambiente extra-social (Byrne \& Whiten 1988) ${ }^{1}$.

Mas talvez a descoberta de impacto mais imediato destes estudos tenha sido a de que os chimpanzés eram capazes de resolver uma série de problemas com o uso de ferramentas - objetos selecionados no ambiente (e eventualmente modificados), tais como "martelos" e "bigornas" (de madeira ou pedra) para abrir frutos encapsulados, varetas como sondas para a captura de cupins e formigas-correição, ou esponjas de folhas para retirar água de cavidades (McGrew 1992, Inoue-Nakamura \& Matsuzawa 1997).

\subsection{Uso de ferramentas em animais não-humanos}

O uso de ferramentas - numa acepção restrita do termo - já foi apontado como uma característica definidora da "natureza humana", em contraposição ao restante do reino animal (Oakley 1949). Entretanto, conforme a amplitude da

\footnotetext{
${ }^{1}$ V. Ottoni 2009
} 
definição adotada, variará o "panorama" do uso de ferramentas entre os animais não-humanos; caracterizar teias de aranha como ferramentas poderia até nos soar adequado (embora não sejam "objetos soltos"), enquanto que incluir na categoria, por exemplo, as fezes lançadas por primatas arborícolas contra predadores potenciais (Chevalier-Skonikoff 1989) talvez seja ampliar excessivamente o conceito. Ao longo de nossa pesquisa, temos empregado a definição de Beck (1980) de uso de ferramentas como "o emprego externo de um objeto solto do ambiente para alterar, com mais eficiência, a forma, a posição ou a condição de outro objeto, de outro organismo ou do próprio usuário, quando este segura ou carrega a ferramenta durante ou logo antes de seu uso e é responsável pela orientação adequada e efetiva da ferramenta" ${ }^{2}$. Para uma discussão recente destas definições e uma proposta que inclui no conceito a mediação do fluxo de informações entre o organismo e o ambiente (e não apenas a alteração de propriedades físicas de objetos), vide St Amant \& Horton (2008).

Mas o uso de ferramentas não implica necessariamente em cognição complexa; teias de aranha e ninhos de joão-de-barro resultam de comportamentos razoavelmente estereotipados e generalizados, i.e., "típicosda-espécie" (ou "típicos-do-contexto", cf. Parker \& Gibson 1977), bastante distintos da solução criativa de problemas exibida pelos chimpanzés e outros pongídeos em cativeiro. Registros de casos simples de uso ferramentas na natureza incluem lontras (Hall \& Schaller 1964), castores (Thomsen, Campbell \& Rosell 2007), golfinhos (Krützen et al 2005). dentre outros (para uma revisão clássica, ver Beck 1980) - sem contar os inumeráveis relatos acerca de animais cativos. Formas simples de uso de ferramentas são observadas em diversas espécies no contexto do cuidado corporal, como no uso de algum objeto para coçar-se, seja na natureza (Macaca radiata: Sinha 1997; Pan paniscus, Hohmann \& Fruth 2003; Pan troglodytes, Lawick-Goodall 1970, Nishida \& Nakamura 1993; Pongo pygmaeus, Galdikas 1982; Ateles geoffroyi,

\footnotetext{
2 Anteriormente, Alcock (1972), baseando-se em Goodall (1970), caracterizou o uso de ferramentas como "a manipulação de um objeto inanimado, não internamente manufaturado, com o efeito de melhorar a proficiência do animal em alterar a posição ou forma de algum objeto separado". Nesta definição, o "não internamente manufaturado" (não especificado em Goodall ou Beck) exclui tanto teias quanto fezes. E, naturalmente, nenhuma destas definições incorpora o sentido quase metafórico das "ferramentas sociais" a que se refere Kummer (1967).
} 
Lindshield \& Rodrigues 2009) em ambientes urbanos ou em cativeiro (Leontopithecus rosalia, Stoinski \& Beck 2001; Macaca fascicularis, Watanabe, Urasopon \& Malaivijitnond 2007; Elephas maximus, Hart et al 2001).

Nos últimos anos, ganharam bastante destaque na literatura as capacidades cognitivas complexas dos corvídeos, incluindo o uso de ferramentas por corvos da Nova Caledônia (Corvus moneduloides), que produzem "ganchos" e "espátulas" a partir de folhas para extrair larvas de troncos de árvores (Hunt 1996); os estudos em laboratório (Weir et al 2002) têm mostrado uma forte predisposição "inata" da espécie para o uso destas ferramentas, que parece independer, em grande parte, de aprendizagem socialmente mediada - como também verificamos no uso de ferramentas por araras azuis (Anodorhynchus hyacinthinus; Borsari \& Ottoni 2005).

\subsection{Uso de ferramentas em primatas não-humanos}

O uso criativo de objetos por chimpanzés no laboratório já era conhecido há tempos (Köhler 1925) e revelou muito sobre as capacidades cognitivas individuais nesta espécie, mas envolvia situações artificiais e a influência humana direta. Ao contrário do observado no laboratório, onde, sob condições adequadas, diversas espécies de primatas (incluídos todos os pongídeos) podem se utilizar de objetos extra-corporais na solução de problemas, o uso plástico e disseminado de ferramentas na natureza aparentemente se restringia aos chimpanzés.

Este era o panorama em 1995, quando "descobrimos" o uso de ferramentas pelos macacos-prego do Parque Ecológico do Tietê.

O caso dos orangotangos era particularmente interessante, considerando-se o seu desempenho em experimentos similares aos de Köhler (Byrne 1995) e a destreza impressionante de ex-cativos, em centros de reabilitação, na imitação de usos de ferramentas pelos humanos (Russon \& Galdikas 1993). Pouco tempo depois, surgiram os primeiros relatos de uso de ferramentas em grupos selvagens, aparentemente restrito a umas poucas populações vivendo em condições bastante particulares, onde a ecologia favorecia um grau mais elevado de gregariedade que o costumeiro entre os 
orangotangos (van Schaik, Fox \& Sitompul 1996).

Embora os gorilas (Gorilla gorilla) também se mostrem razoavelmente destros no cativeiro, são extremamente raros os relatos de uso de ferramentas nesta espécie (Breuer 2005, Wittiger \& Sunderland-Groves 2007), na qual, talvez, o desenvolvimento cognitivo tenha sido em parte sacrificado em favor de um rápido desenvolvimento corporal. Byrne \& Russon (1998), entretanto, observaram seqüências comportamentais estruturalmente complexas na manipulação, pelos gorilas, de determinados alimentos (protegidos por espinhos ou pelos urticantes), comparáveis em complexidade ao uso de ferramentas (estas sendo talvez dispensáveis graças à grande força muscular característica da espécie).

Por outro lado, o uso de ferramentas jamais foi registrado entre os bonobos na natureza (Pan paniscus), o que é ainda mais intrigante considerando-se o desempenho manipulativo desta espécie em laboratório inclusive no que se refere à confecção e uso de ferramentas líticas (Toth et al 1993, Kathy et al 1999) e sua tendência a superar os chimpanzés em tarefas de uso induzido de linguagem (Savage-Rumbaugh \& Lewin 1994).

Entre os macacos do Velho Mundo, descontados alguns relatos anedóticos, a única espécie em que o uso espontâneo de ferramentas vem sendo observado são os macacos-de-cauda-longa (Macaca fascicularis), que utilizam pedras e conchas para soltar e/ou quebrar ostras, gastrópodes, bivalves, caranguejos e frutos encapsulados (Malaivijitnond et al 2007, Gumert, Kluck \& Malaivijitnond 2009) 4 .

A variabilidade no desempenho de primatas que não usam ferramentas na natureza em tarefas de laboratório envolvendo a solução de problemas com o uso de objetos levou alguns pesquisadores a supor que as capacidades cognitivas subjacentes ao uso de ferramentas não sejam "específicas de domínio": macacos vervet (Cercopithecus aethiops), que não usam ferramentas na natureza, exibem acertos e fracassos comparáveis aos dos chimpanzés em

\footnotetext{
${ }^{3}$ Para uma discussão sobre as relações neurais e cognitivas entre linguagem e ferramentas, v. Greenfield 1991).

${ }^{4}$. E em circunstâncias muito particulares de interação com humanos (num templo budista), um grupo destes macacos exibe uma forma peculiar de uso de ferramentas: cabelos humanos como fio dental (Watanabe, Urasopon \& Malaivijitnond 2007).
} 
tarefas similares - o que não acontece com sagüis (Saguinus oedipus; Santos et al 2006), que não foram capazes de reconhecer adequadamente alguns dos aspectos funcionais das ferramentas. Estes últimos, no entanto, foram capazes de distinguir entre aspectos relevantes e não-relevantes das ferramentas no estudo de Hauser, Pearson \& Seelig $(2002)^{5}$ e, com treino suficiente, de resolver problemas envolvendo a combinação de duas ferramentas (Santos et al 2005).

\subsection{Os macacos-prego de topete}

Se as observações naturalísticas sobre a utilização de ferramentas por chimpanzés nos levaram a repensar uma série de concepções tradicionais quanto ao caráter "único e exclusivo" das capacidades tecnológicas humanas, a descoberta de comportamentos similares em outras espécies de primatas, e particularmente em um único gênero de primata do Novo Mundo, nos leva, por sua vez, a questões mais amplas, que apontam para as condições e mecanismos cognitivos, ecológicos e sociais que favorecem o seu surgimento.

Os macacos-prego "com topete", antigamente pertencentes a uma única espécie (Cebus apella) são encontrados do norte da América do Sul até o sul do Brasil, Paraguai e norte da Argentina (uma distribuição que, por si só, reflete sua plasticidade comportamental), vivendo em grupos de 3 a 40 indivíduos (Lynch \& Rímoli 2000) $^{6}$, com estrutura multi-macho/multi-fêmea (Terborgh 1983) - na proporção de um macho adulto para cada 4 fêmeas adultas (Brown \& Colillas 1984, Freese \& Oppenheimer 1981). Em comparação com espécies de tamanho corpóreo similar, por exemplo, como o mico-de-cheiro (Saimiri sciureus), o infante de macaco-prego permanece mais tempo com a mãe e tem uma infância socialmente mais ativa (Fragaszy, Baer \& Adams-Curtis 1991) e apresenta um Quociente de Encefalização (proporção entre o tamanho do cérebro e a massa corporal) maior, mais próximo do dos pongídeos (Jerison

\footnotetext{
${ }^{5}$ Parcialmente replicado com um papagaio verdadeiro (Amazona aestiva) por MendonçaFurtado \& Ottoni (2008).

${ }^{6}$ Certas populações de C. libidinosus podem incluir grupos ainda maiores (v. adiante).
} 
1973, Rilling \& Insel 1999). As antigas subespécies de C. apella são atualmente classificadas como espécies: C. nigritus, C. libidinosus, C. xanthosternos e C. apella (antiga "C. apella apella") ${ }^{7}$.

Os macaco-prego são forrageadores generalistas e oportunistas, com uma dieta bastante diversificada, incluindo não apenas frutos, folhas, flores, brotos e outras partes vegetais, mas também presas animais como artrópodes, ovos e pequenos vertebrados (Ferreira et al 2002, Resende et al 2003, Verderane et al 2007). Muitos destes itens alimentares requerem, para sua localização e/ou consumo, técnicas sofisticadas de manipulação cuja aquisição individual possivelmente envolve mecanismos de transferência social de informação.

As convergências comportamentais com os chimpanzés (Visalberghi \& McGrew 1997) não se restringem à manipulação complexa de objetos, mas se refletem também em outras áreas de sua vida social (elevada tolerância, especialmente para com os jovens, partilha de alimento etc), o que confere aos macaco-prego uma importância estratégica no estudo comparativo da evolução da socialidade e da cognição primata.

\subsection{Capacidades cognitivas dos macacos-prego}

Alguns autores buscaram aplicar o modelo Piagetiano para a ontogênese da cognição humana ao desempenho de primatas não-humanos. ChevalierSkolnikoff (1989), por exemplo, chega a atribuir ao macaco-prego capacidades inerentes ao Período Pré-Operatório, embora caracterize a maior parte dos comportamentos mencionados em sua revisão como indicadores dos Estágios 5/6 do Período Sensório-Motor. Este último seria um patamar mais em concordância com os outros pesquisadores que seguem esta abordagem, como Natale \& Antinucci (1989; v. tb. Natale 1989), Spinozzi \& Potí (1989) ou Gibson (1990). As extrapolações de Chevalier-Skolnikoff no artigo citado, no entanto, baseiam-se em grande parte em relatos anedóticos isolados ou

\footnotetext{
${ }^{7}$ Para uma ampla revisão sobre o gênero Cebus, v. Fragaszy et al 2004.
} 
condições em que falta informação pregressa adequada. E a própria transposição de um modelo submetido a tantos questionamentos já em seu contexto original (v. Gelman 1978) pode ser de valor duvidoso para a compreensão dos processos de desenvolvimento em outras espécies, ignorando-se a possibilidade de coerções típicas-da-espécie 'canalizando' o desenvolvimento intelectual.

As observações de Fragaszy \& Adams-Curtis (1991) não parecem apoiar as previsões a respeito da relação entre comportamentos combinatórios e início do uso de ferramentas feitas a partir da teoria neo-piagetiana (outras observações sobre a ontogênese da manipulação em Cebus cativos podem ser encontradas em Adams-Curtis \& Fragaszy 1994).

Gibson (1990) sugere que haveria uma 'canalização' no desenvolvimento ontogenético do macaco-prego em direção à manipulação de objetos (mais freqüente nos infantes de Cebus que nos de outras espécies de macacos, de acordo com Antinucci 1990), mas não nos domínios vocais ou imitativos. A imitação estaria restrita ao Estágio 3 (imitação ${ }^{8}$ de ações já presentes no repertório comportamental do indivíduo).

Além disso, há uma série de problemas metodológicos na tentativa de se aplicar tarefas piagetianas a primatas não-humanos, como mostra a discussão dos resultados polêmicos obtidos com Cebus em experimentos sobre a noção de permanência do objeto (Dumas \& Brunet 1994).

O desempenho cognitivo dos macacos-prego tem sido examinado no laboratório em diversos tipos de tarefas, envolvendo, por exemplo, a abertura de caixas-problema (Simons \& Holtkötter 1986, Resende \& Ottoni 2001), o auto-controle em tarefas envolvendo uso de ferramentas (Evans \& Westergaard 2006), a "navegação" em labirintos virtuais bidimensionais (Fragaszy et al 2008), o uso de dicas do experimentador em problemas de escolha (Anderson, Sallaberry \& Barbier 1995), o reconhecimento ao espelho (Collinge, 1989, de Waal, Dindo \& Freeman 2005, Roma et al 2007), a conservação de quantidades (Beran 2008), a facilitação social em tarefas

\footnotetext{
${ }^{8}$ Note-se que o termo imitação é utilizado pelos autores de orientação neo-piagetiana (como Gibson 1990) em um sentido diferente daquele a que nos referiremos ao tratar da aprendizagem por imitação (e suas evidências), caso em que a definição operacional empregada exclui comportamentos já presentes no repertório do indivíduo.
} 
exploratórias de forrageamento (Dindo, Whiten \& de Waal 2009) ou os efeitos da cooperação sobre a partilha de alimento (de Waal \& Berger 2000). AdamsCurtis (1990) estudou a aprendizagem de conceitos, Tavares e Tomaz (2002), a memória em tarefas de "(não-)pareamento com atraso ao modelo", enquanto que os macacos-prego da "Escola de Primatas" da Universidade Federal do Pará são estudados, à luz dos paradigmas da Análise Experimental do Comportamento, em suas capacidades discriminativas e de formação de classes arbitrárias (Barros \& Galvão 2002, Barros, Galvão \& Mcllvane 2002).

Uma longa controvérsia se seguiu (continua se seguindo) aos experimentos sobre um sentido de "justiça" ("fairness") dos macacos-prego, que reagiam muito negativamente ao receber um pedaço de comida menos preferida (pepino) pela mesma tarefa que, para um coespecífico ao lado, havia resultado em uma uva (Brosnan \& de Waal 2003, Heinrich 2004, Wynne 2004, Roma et al 2006, Silberberg et al 2006, Dindo \& de Waal 2007, Fletcher 2008, Silberberg et al 2009).

Macacos-prego cativos se mostraram capazes não apenas de trocar diferentes "fichas" (tokens) por diferentes tipos de alimento, como também por ferramentas (Westergaard et al 1998), e indivíduos mais experientes no uso de ferramentas foram capazes de evitar comer um item alimentar menos preferido, em forma de bastão, para usá-lo subseqüentemente como ferramenta para obter um alimento mais atraente (Westergaard, Evans \& Howell 2006). Quando submetidos a escolhas entre fichas valendo uma (tipo $A$ ) ou 3 recompensas (tipo B), ao menos parte dos sujeitos era capaz de escolher uma ficha $B$ contra 1-2 fichas $A$ (mas não contra 4-5 destas), e, em alguns casos, de escolher 2 fichas B contra 4 fichas A (Adessi, Crescimbene \& Visalberghi 2007). Em tarefas envolvendo a escolha de conjuntos de itens alimentares $(N=1-5)$ ou de fichas que poderiam ser trocadas por quantidades equivalentes, os macacos exibiram julgamentos adequados de numerosidade relativa em ambos os casos, embora seu desempenho tenha sido superior com os itens alimentares que com as fichas, talvez em função da maior demora na obtenção da recompensa (Adessi, Crescimbene \& Visalberghi 2008).

\footnotetext{
9 "Delayed (non-)matching to sample".
} 


\subsection{Estudos sobre manipulação de objetos por macacos-prego cativos}

A destreza manual de macacos-prego já era conhecida nos tempos do avô de Charles Darwin, Erasmus (1794, apud Visalberghi 1990), que descreveu o uso de pedras para quebrar nozes por um velho animal cativo, e foi objeto de relatos como o de Cooper \& Harlow (1961), que observaram o uso de uma vareta como arma durante um evento agonístico entre animais enjaulados. Croizat (1962, apud Urbani 2002), acompanhando o desenvolvimento da habilidade de quebrar frutos encapsulados com pedras em um macaco-prego cativo, considerou que este exibia um "estágio intermediário" - o de escolha adequada de ferramentas - entre a capacidade de confeccionar ferramentas e o do seu uso casual. E Anderson (1990) observou no laboratório a utilização de pedras na quebra de frutos encapsulados, mas supôs que os macacos-prego não usariam pedras como "martelos" na natureza em função do hábito arbóreo. Relatos anedóticos sobre o uso de ferramentas por macacos-prego em parques zoológicos são abundantes (v., p.ex., Ferreira, Cavalcanti, \& Souto 1996, Urbani 1999, Mendes et al 2000). Os estudos experimentais sistemáticos, no entanto, começaram a surgir na literatura com trabalhos como os de Gregory Westergaard, Dorothy Fragaszy e Elisabetta Visalberghi.

\subsubsection{Uso experimentalmente induzido de ferramentas}

Westergaard \& Fragaszy (1987) observaram experimentalmente o uso e/ou modificação de varetas (como sondas para a obtenção de xarope) e esponjas de papel-toalha (para beber água), estabelecendo algumas comparações com comportamentos similares em chimpanzés e assinalando a importância do contexto social (caso do filhote com sua mão sobre a da mãe enquanto esta extraía o xarope). Ao contrário do observado para outros macacos, os autores registraram a ocorrência de diferentes formas de manufatura das ferramentas, às vezes executadas a alguma distância e sem contato visual com o local de utilização (fonte de alimento), além de estratégias de enganação para evitar o "roubo" de uma ferramenta por outros indivíduos. 
Em artigos subseqüentes, Westergaard e Suomi enfocaram uma série de comportamentos manipulatórios experimentalmente induzidos, como o uso seqüencial de pedras e varetas para quebrar nozes e extrair a semente (Westergaard \& Suomi 1993a) ou a modificação e uso combinado de ferramentas de pedra ou de osso (idem, 1994a, 1994b). Estes autores estudaram ainda os padrões de manipulação combinatória no pareamento de objetos (idem, 1994c) e a lateralidade na manipulação de ferramentas (idem, 1993b, 1994e, 1994f). Westergaard \& Suomi (1994d) assinalam algumas implicações destes resultados para o estudo da evolução dos primatas e da hominização, sugerindo que o macaco-prego poderia se constituir em um modelo comparativo bastante útil para a estudo dos fatores cognitivos e neurológicos subjacentes ao desenvolvimento da manipulação complexa de objetos em primatas.

\subsubsection{Manipulação de objetos e compreensão da causalidade física}

Visalbergh \& Trinca (1989) submeteram seus sujeitos a um experimento envolvendo a extração de amendoins de um tubo horizontal transparente com o uso de diferentes objetos (adequados ou não, mas passíveis de modificação) para empurrá-los. Os macacos-prego eram capazes de modificar as ferramentas - mas apenas diante do insucesso inicial. Embora os erros no desempenho da tarefa diminuíssem com o tempo, não desapareciam por completo - o que, para as autoras, aponta para uma diferença entre o nível do desempenho e o da compreensão: os sujeitos aprenderiam por meio da exploração ativa (tentativa-e-erro), sem uma representação mental do problema.

Obtiveram-se resultados análogos no experimento seguinte (Visalberghi \& Limongelli 1994), em que os sujeitos se deparavam com uma tarefa similar à anterior, mas onde o tubo era dotado de uma "armadilha" - um compartimento rebaixado na região central onde o amendoim cairia (e não poderia mais ser extraído) caso a ferramenta (bastão para empurrar o amendoim) fosse introduzida pelo lado errado do tubo (o mesmo lado do amendoim em relação à armadilha). Os sujeitos não atingiram um nível de desempenho isento de erros, e na situação subseqüente - onde o tubo era girado de maneira a que a 
armadilha ficasse virada para cima (tornando-se inoperante), continuavam a empurrar o amendoim muito lentamente quando este passava pela região central do tubo - resultados que parecem corroborar a hipótese de que faltaria a estes animais a compreensão dos mecanismos de causa-e-efeito envolvidos no problema. Tal compreensão estaria, consideraram as autoras, possivelmente restrita aos pongídeos, conforme sugerido por experimentos envolvendo a aplicação dos mesmos testes com os tubos a chimpanzés, bonobos e um orangotango (Visalberghi, Fragaszy \& Savage-Rumbaugh 1995) - embora reavaliações destes resultados tenham questionado até certo ponto esta interpretação (Tomasello \& Call 1997).

\subsubsection{Experimentos sobre imitação e difusão de comportamentos}

Fragaszy \& Visalberghi (1989) estudaram os processos de aprendizagem em macacos-prego na solução de dois problemas envolvendo a manipulação de ferramentas (quebra de nozes e uso de um dispensador de sementes de girassol), concluindo que o preditor primário de sucesso nas tarefas era o nível individual de interesse; não foi verificado um efeito de facilitação pela observação de outros indivíduos junto ao aparato - a maior parte da exploração ocorria quando os sujeitos estavam sós. Os indivíduos aprendiam prontamente a relação entre a ferramenta e a comida, mas não houve imitação do comportamento manipulatório do modelo. Situações de facilitação social apenas foram observadas diante da introdução experimental de alimentos desconhecidos (Visalberghi \& Fragaszy 1995).

Estas autoras mostraram (Fragaszy \& Visalberghi 1990) que determinados processos sociais afetam o aparecimento de comportamentos inovadores de maneiras opostas: revisando uma série de experimentos, concluíram que foram observados (além de um único caso de co-ação envolvendo uma díade mãe-filhote) efeitos de "social enhancement" (quando a atenção de um animal é atraída para um local ou objeto do ambiente pela atividade de um coespecífico), por um lado, e efeitos sociais inibidores, como restrições no acesso ao aparato por parte de animais mais dominantes (restrição ativa ou presença inibidora) e o "roubo" de ferramentas por outros indivíduos. Estes efeitos inibidores determinaram uma maior atividade 
exploratória quando os indivíduos se encontravam sós no aparato (o que, por si só, já dificultaria a ocorrência de imitação). Além disso, os "solucionadores" das diferentes tarefas experimentais não eram necessariamente os mesmos indivíduos. Esta é uma constatação interessante, à luz das observações de Giraldeau \& Lefebrve (1986) com pombos, sobre a troca de papéis entre "manipuladores" e "parasitas" (scroungers; v. adiante) em diferentes tarefas (e as possíveis implicações disso para a adaptação do grupo como um todo).

Visalberghi \& Fragaszy (1990b) induziram experimentalmente a disseminação do comportamento de lavagem de comida em um grupo de macacos-prego: só alguns indivíduos aprenderam a lavar o alimento sujo de areia e não se observaram evidências de imitação; algumas situações de "scrounging" (consumir sobras de alimento obtido/processado por outro ${ }^{10}$ ) foram observadas (neste estudo, ao contrário da maioria dos casos, os animais mais velhos aprenderam o novo comportamento mais cedo).

A fim de examinar a influência da atividade exploratória dos indivíduos mais velhos sobre a dos mais novos diante do aparato experimental (em duas tarefas, uma de quebra de nozes, outra de obtenção de iogurte por meio de palitos), mas evitando que os mais velhos impedissem o acesso dos jovens ao mesmo, Fragaszy, Vitale \& Ritchie (1994), construíram uma situação onde dois aparatos iguais eram oferecidos, um na área central do cativeiro e outro em uma área protegida, à qual apenas infantes e juvenis tinham acesso. Verificouse que a atividade dos juvenis era pouco coordenada com a dos adultos - e quando havia sinais de coordenação, isto se dava entre os juvenis mais jovens - mas apenas juvenis mais velhos solucionaram adequadamente a tarefa.

A influência de modelos (coespecíficos) experientes na solução de uma tarefa - no caso, a abertura seqüencial de vários fechos de uma tampa para obter uma passa (Adams-Curtis \& Fragaszy 1995) pareceu se restringir a um efeito de "local enhancement" ("realce de local") - e apenas sobre os juvenis (mais tolerados socialmente, mais coesos como grupo etário e, aparentemente, mais curiosos); em se tratando de uma tarefa envolvendo uma seqüência de operações, foi possível comparar o desempenho dos "manipuladores", não

\footnotetext{
${ }^{10}$ Conservaremos o termo inglês "scrounging" porque "parasitismo" é uma tradução que não nos agrada, por vários motivos, e não encontramos por ora um termo melhor.
} 
tendo sido constatado qualquer aumento gradual na correspondência entre 0 comportamento de "manipuladores" e "observadores". Apenas dois indivíduos (machos adultos) em cada um de dois grupos testados em uma tarefa de quebra de nozes (Visalberghi 1987) solucionaram o problema (sozinhos, por tentativa-e-erro), mas não houve qualquer difusão do novo comportamento, embora outros indivíduos pudessem observar os "manipuladores".

Ao se discutir este tipo de resultados, entretanto, é preciso levar em conta os eventuais efeitos da condições artificiais do cativeiro. No grupo em questão, por exemplo, a proporção de machos adultos era excessiva (em comparação com os padrões naturais), e foram observados alguns aspectos atípicos no comportamento de macacos-prego, como a ausência de competição entre os indivíduos pelas nozes e ferramentas. Em nosso primeiro estudo com esta espécie, por exemplo (extração de melado com uso de palitos, Perondi, Izar \& Ottoni 1995), os palitos e o acesso ao dispensador de melado eram objeto de disputas às vezes bastante intensas.

\subsection{Primeiras observações naturalísticas de manipulação de objetos}

Relatos sobre o uso espontâneo de ferramentas por macacos-prego remontam aos escritos de Gonzalo Fernández de Oviedo em 1526 (apud Urbani 1988). Entretanto, embora a intensa propensão manipulatória do macaco-prego seja um elemento fundamental em seu comportamento exploratório de espécie generalista e oportunista, eram até recentemente escassos na literatura os relatos sobre comportamentos envolvendo manipulação sofisticada de objetos em condições naturais. Em geral, estes comportamentos eram observados em situações de forrageamento (Chevalier-Skolnikoff 1990), tais como a abertura de frutos encapsulados. A quebra de cocos (Astrocharium chambira) golpeados contra os nós do caule de um bambu (ou um coco contra outro) foi descrita há mais de trinta anos (Izawa \& Mizuno 1977; Struhsaker \& Leland 1977) ${ }^{11}$.

\footnotetext{
${ }^{11}$ Um comportamento semelhante foi também observado em cativeiro por Ferreira, Cavalcanti \& Souto (1996).
} 
Alguns relatos anedóticos envolvem o uso de objetos como "armas" (Boinski 1988; Chevalier-Skolnikoff 1990), outros se referem a contextos de exploração de objetos novos ou brincadeira (Chevalier-Skolnikoff 1990; Perondi, com. pessoal), incluindo-se aí a manipulação exploratória de animais de outras espécies (Chevalier-Skolnikoff 1990; Savastano, com. pessoal). Fernandes (1991) observou um macaco-prego quebrando ostras de mangue (com um "martelo" também feito de ostras).

Alguns dos exemplos acima se enquadram na definição de "uso de ferramenta" de Beck (1980; v. acima), mas a maioria - como o uso de um substrato duro para quebrar frutos encapsulados - se parece mais com o que Parker \& Gibson (1977) chamaram de "proto-ferramentas" e Panger (1998), de "uso de objetos" - quando apenas o "objeto de mudança" é manipulado, mas não o "agente de mudança". De acordo com estes critérios, Panger (op.cit.), embora tenha registrado numerosos casos de "uso de objetos" por Cebus capucinus selvagens, não observou um único caso de "uso de ferramentas" observado apenas em cativeiro - como também acontece com C. olivaceus, (Urbani 1999, Dubois et al 2001). A única exceção "naturalística" entre os cairaras é a observação, por Phillips (1998), de alguns episódios de uso de folhas como "copos" para retirar água de ocos de árvores por Cebus albifrons trinitatis (também denominados "macacos-prego de cara branca").

Este era o "estado da arte" quando iniciamos nossos primeiros estudos sobre o uso (induzido) de ferramentas por macacos-prego utilizando uma versão (parcial/modificada) de um experimento realizado em laboratório por Westergaard \& Fragaszy (1987; v. acima). O intuito era verificar se, mesmo em condições de vida mais "naturalísticas", os macacos aprenderiam a acessar o melado contido em uma caixa com furos na tampa, utilizando varetas como sondas.

O grupo semi-cativo, à época com cerca de 50 indivíduos, vivia numa ilha de $4000 \mathrm{~m}^{2}$ no Parque Ecológico do Tietê (PET; São Paulo, SP). Ao longo de uma série de sessões de 30 minutos (2-4 por semana), os animais foram expostos a um aparato constituído por uma plataforma (presa a uma árvore) na qual era fixada uma caixa metálica com orifícios, através dos quais se poderia obter melado. Varetas de madeira, ferramentas potenciais para essa finalidade, 
eram oferecidas ao lado da caixa, sobre a plataforma.

Três animais juvenis aprenderam a obter o melado com o auxílio das varetas (e a quebra das varetas na manipulação exploratória por estes indivíduos diminuiu drasticamente...). Davi, o "inovador", foi seguido por Igor e Caquinho (que haviam observado Davi usando as ferramentas por 3 e 7 vezes, respectivamente). Alguns outros juvenis adotaram uma estratégia de "scrounging", acompanhando os manipuladores bem-sucedidos à plataforma para tentar lamber os restos de melado nos orifícios ou de varetas descartadas (Perondi, Izar \& Ottoni 1995).

Buscando observar a inserção do uso de ferramentas pelos macacosprego no contexto mais amplo da estrutura social e dos processos de facilitação social e competição concomitantes (dos quais, nos parecia, o estudo em laboratório não poderia dar conta em sua plenitude), observamos os vários graus de tolerância aos "scroungers" por parte dos manipuladores, as eventuais "contra-estratégias" destes, e os efeitos da presença dos machos adultos na plataforma: como estes muitas vezes deslocavam os manipuladores, nos parecia haver aí uma possível barreira impedindo uma eventual aprendizagem observacional pelos mais velhos e dominantes ${ }^{12}$.

Não tínhamos como imaginar, na época, quantas coisas este estudo antecipava: o uso espontâneo de varetas como sondas viria a ser descoberto em apenas algumas populações da Serra da Capivara, por enquanto - e o "oportunismo" dos "scroungers" mostrou-se um aspecto central do uso de ferramentas em outros contextos. À época, acreditava-se que a estratégia de "parasitar" a atividade de sujeitos que resolviam um problema de obtenção de alimento poderia ser um obstáculo à aprendizagem da solução do problema, em si, pelos "scroungers", como havia sido observado no laboratório, com pombos (Palameta \& Lefebvre 1985, Giraldeau \& Lefebvre 1987) - mas não é necessariamente assim, como constatamos mais adiante com os macacosprego.

\footnotetext{
${ }^{12}$ Este estudo foi mais tarde replicado com os macacos da Área de Preservação do PET, com resultados semelhantes (Aquino \& Ottoni 2001; v. adiante).
} 


\subsection{A descoberta do uso espontâneo de ferramentas em semi- liberdade}

O evento decisivo para os rumos desta pesquisa foi a informação que Angela Perondi ouviu de um dos tratadores do Parque do Tietê, e me relatou na primavera de 1995.

Angela tinha de retornar da ilha - com o tratador que conduzia o barco atravessando a "Área de Preservação" do PET, fechada à visitação e habitada por diversas espécies de animais. Dentre estes, havia um grupo de macacosprego formado, alguns anos antes, por animais fugidos das ilhas, ali vivendo e se reproduzindo (nem todos os machos haviam sido castrados) em condições que (inspirados em definições tiradas da literatura sobre babuínos) chamamos de "semi-liberdade". Numa daquelas tardes, retornando da ilha, Angela ouviu sons percussivos vindos da mata e perguntou ao tratador quem os produzia, ao que este respondeu, como se se tratasse da coisa mais natural do mundo, que "eram os macacos-prego quebrando coquinhos com pedras".

Por alguns momentos, considerei a possibilidade de que a aluna, sabendo da significância teórica do uso espontâneo de ferramentas pelos chimpanzés selvagens, estivesse tentando manter aceso meu interesse por aqueles macaquinhos que eu não tinha em tão alta conta...

Não era o caso.

Em função de alguns relatos anedóticos e observações indiretas sugerindo o uso espontâneo de ferramentas por macacos-prego selvagens, demos aos animais o benefício da dúvida e fomos em busca da confirmação do relato.

Nas nossas primeiras visitas à Área de Preservação do PET, nos deparamos com algo fascinante - que se tornaria para nós uma imagem rotineira e familiar: sítios de quebra de cocos.

A superfície mais ou menos plana de uma pedra ou raiz, um punhado de cascas partidas de coquinhos, e, largada ao lado, uma pedra de bom tamanho para se segurar com mãos pequenas.

E a história do Laboratório de Etologia Cognitiva mudou para sempre. 
Capítulo 2. O uso espontâneo de ferramentas em semiliberdade

Em função do relato registrado por Angela Perondi sobre a quebra de cocos de jerivá por macacos-prego do Parque Ecológico do Tietê, realizamos um levantamento inicial e encontramos as evidências indiretas deste comportamento, os sítios de quebra (Figura 1) - geralmente compostos de algumas pedras empilhadas e cascas de cocos quebrados (Mannu \& Ottoni 1996). Nesta época, um relato semelhante, de observações feitas em um parque urbano de Londrina (PR), foi apresentado por Rocha, Reis \& Sekiama (1996) - e Langguth \& Alonso (1997) encontraram sítios de quebra com restos de cocos de Syagrus oleracea numa área habitada por macacos-prego selvagens.

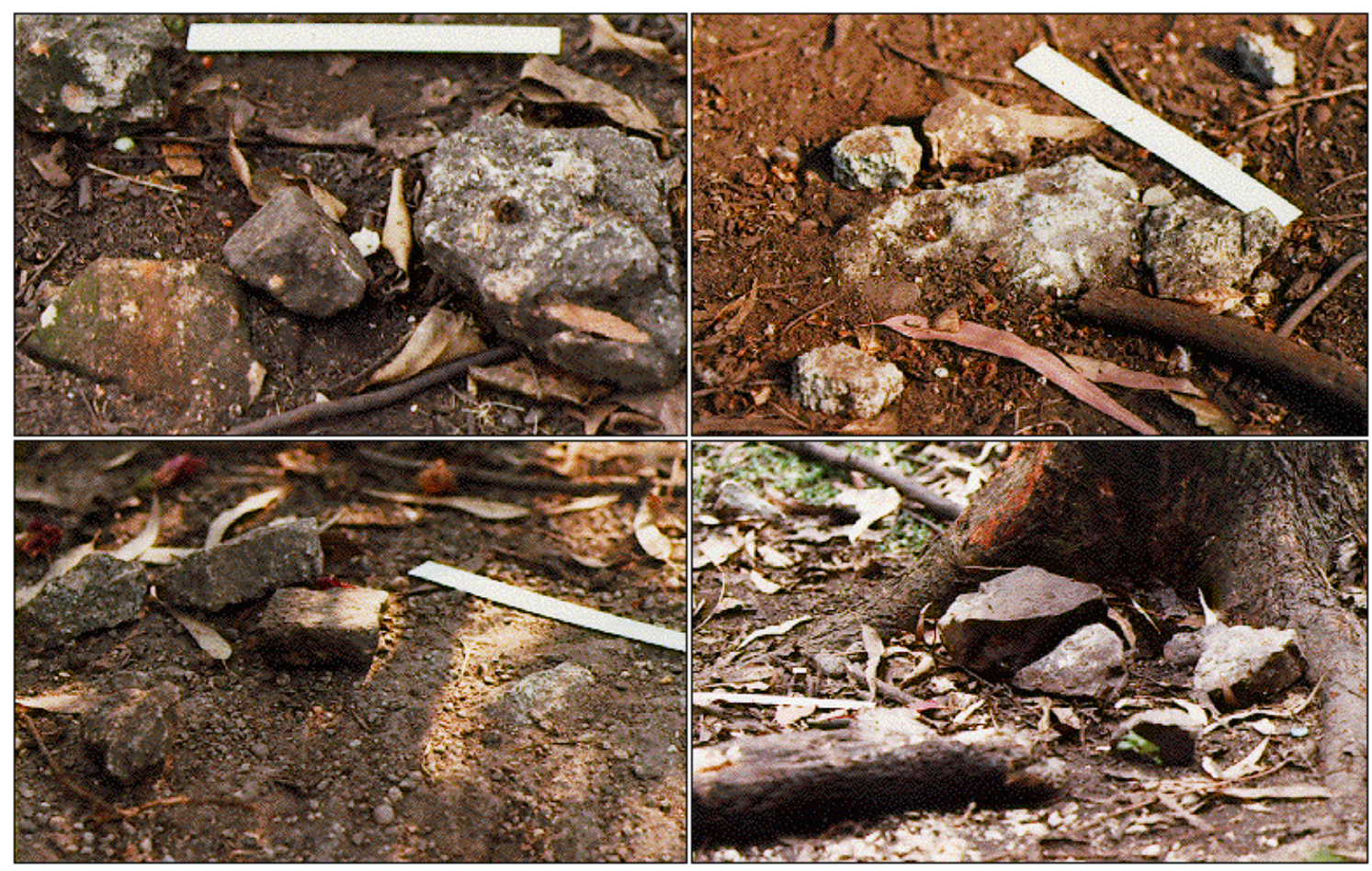

Figura 1. Sítios de quebra de cocos no Parque Ecológico do Tietê (fotos E.B. Ottoni). 
Nossos estudos sistemáticos na Área de Preservação do PET começaram em 1997 (Mannu \& Ottoni 1998), com um mapeamento dos sítios de quebra de cocos, uma vez que constatamos que boa parte deles era reutilizada. Após este estudo-piloto, que levou à descoberta de 87 sítios (dos quais 61 em condições plenas de uso, com "martelos" e "bigornas" presentes), passamos a monitorar a atividade dos animais de forma direta e indireta (uso dos sítios). Os primeiros resultados deste estudo constituíram uma descrição geral do comportamento de quebra de cocos com ferramentas e sua demografia (Ottoni \& Mannu 2001, 2003).

\subsection{O Parque Ecológico do Tietê}

O Parque Ecológico do Tietê (PET; São Paulo, SP) tem uma área de $14 \mathrm{~km}^{2} \mathrm{e}$ é um dos principais locais, na região, de liberação de animais ilegalmente capturados e subseqüentemente apreendidos. Ele abrigava, na época do início da pesquisa, quatro grupos de macacos-prego, três dos quais vivendo em ilhas - dentre os quais, o dos sujeitos do primeiro experimento com varetas (Perondi, Ottoni \& Izar 1995).

O quarto grupo vive em semi-liberdade na "Área de Preservação". Esta área de reflorestamento, com $180.000 \mathrm{~m}^{2}$ (Figura 2), contém algumas edificações de pequeno porte, três lagos, e sua vegetação inclui muitas espécies de árvores, arbustos e quatro espécies de palmeiras, dentre as quais o jerivá (Syagrus romanzoffiana; Figura 3), cujos cocos duros, ovalados e pequenos (com diâmetro de cerca de $1.5 \mathrm{~cm}$ ) são quebrados e consumidos pelos macacos-prego. 


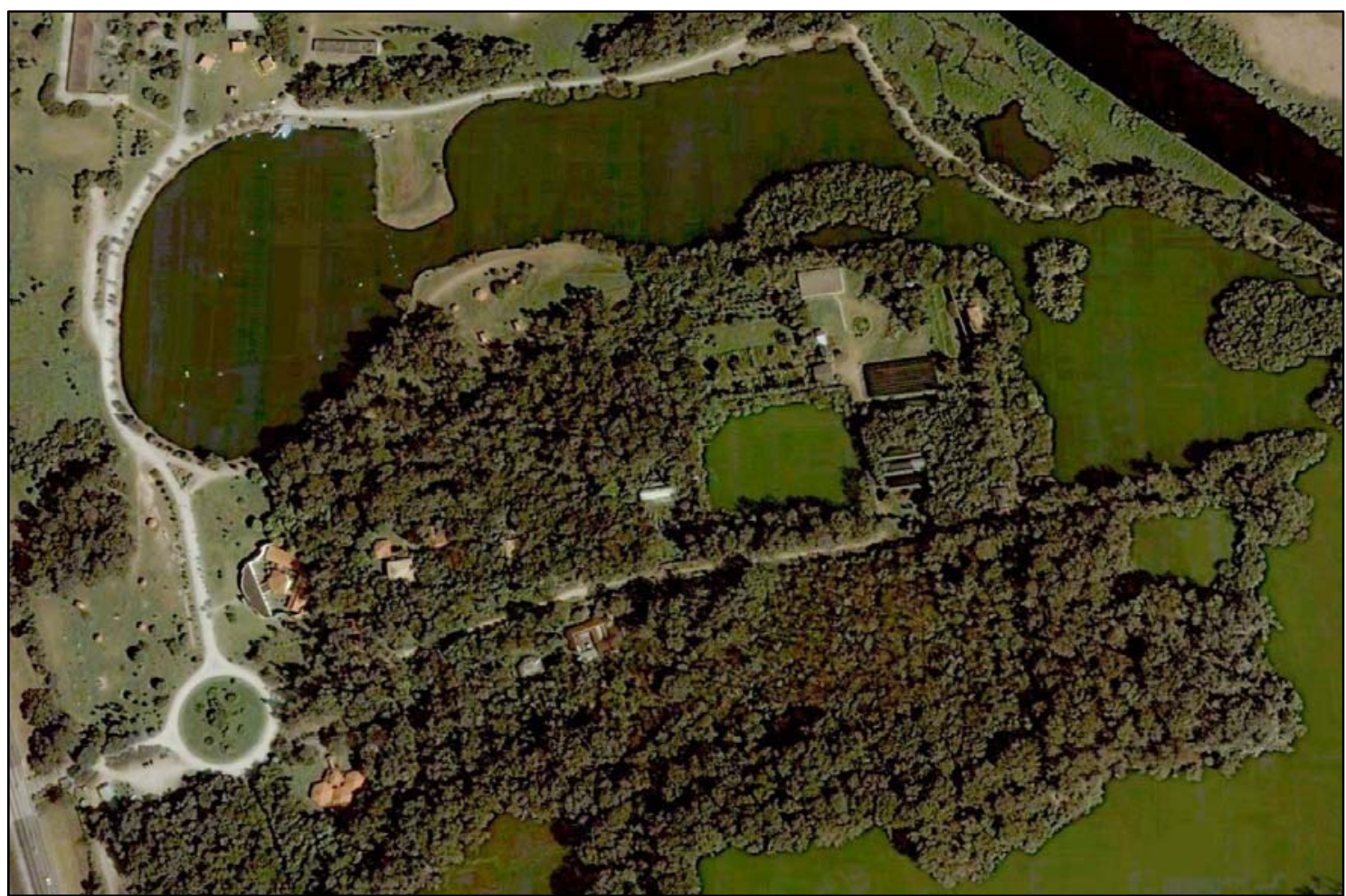

Figura 2. Área de Preservação do Parque Ecológico do Tietê, São Paulo, SP (Google Earth).

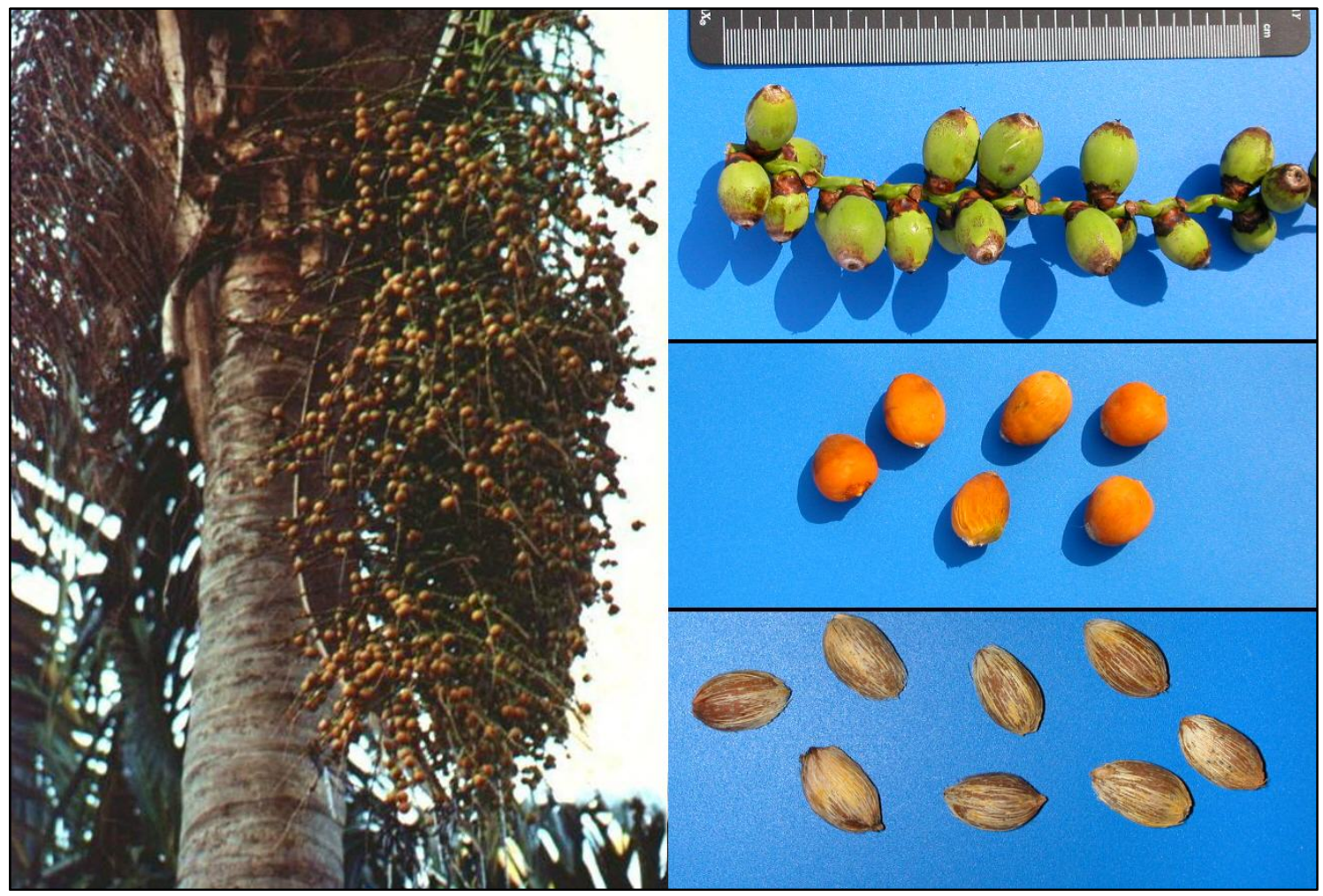

Figura 3. Palmeira e cocos de jerivá, Syagrus romanzofianna (fotos E.B. Ottoni). 


\subsection{O grupo de macacos-prego da Área de Preservação}

Este grupo vive no local desde 1988. Os adultos mais velhos (dois machos e três fêmeas) presentes quando iniciamos nossas observações foram soltos nas ilhas do parque após sua apreensão pelo IBAMA e formaram um grupo espontaneamente, após escapar a nado das ilhas (o último deles, Medeiros, em 1992); todos os outros indivíduos então presentes nasceram no local. Em função da falta de dados detalhados sobre a origem dos animais e das evidências de hibridação, nos referiremos a esta população como constituída por Cebus $\mathrm{sp}^{13}$.

Os macacos eram diariamente aprovisionados, mas não se limitavam à comida fornecida (principalmente frutas, ovos e polenta): ao contrário, forrageavam por toda a área, consumindo itens naturalmente disponíveis. Foi observado que chegassem a ficar longe do comedouro por pelo menos 2 dias, e parte das provisões freqüentemente apodrecia no local, o que indica que eles sobreviveriam sem o aprovisionamento.

O grupo era composto, no início do estudo (agosto de 1997), de 18 indivíduos: quatro machos adultos (dois dos quais castrados, um deles, o provável macho alfa anterior, três fêmeas adultas, dois machos subadultos (5 8 anos) e quatro infantes (um outro macho adulto morreu no início dos estudo e os dados referentes a ele foram excluídos das análises). Os dados apresentados a seguir foram coletados entre agosto de 1997 e outubro de 1998.

\subsection{Metodologia}

A observação indireta envolveu a limpeza semanal (de fevereiro de 1998 a fevereiro de 1999) de todos os sítios de quebra identificados - que consistiam de amontoados de pelo menos 2 pedras (ou, menos freqüentemente, de pedras e pedaços de madeira ou pavimento cimentado), inspecionando os

\footnotetext{
${ }^{13}$ Cebus apella, na acepção antiga do termo, foi usado nas primeiras publicações.
} 
resíduos de cocos de jerivá e registrando seu estado de maturação.

Para a observação direta, empregamos, numa primeira etapa da coleta de dados (de agosto de 2007 a outubro de 2008), o registro de "Todas as Ocorrências" (Martin \& Bateson 1993): ao longo de 132 horas de observação, foram registrados quaisquer eventos de manipulação de pedras e/ou cocos: data e hora, sujeito, sítio, materiais, observação por outros indivíduos e alguns aspectos posturais do comportamento de quebra de cocos.

\subsection{Resultados ( $1^{\mathrm{a}}$ fase)}

O grupo passava a maior parte de seu tempo diário de atividade forrageando e se deslocando de uma fonte de alimento para outra. Além dos alimentos aprovisionados no cocho pela manhã, eles buscavam e consumiam toda uma série de itens alimentares naturalmente disponíveis, sazonalmente variáveis, tais como plantas, ovos, larvas e pequenos animais, inclusive pequenos vertebrados (Resende et al 2003). A caça de aves pelos macacos do PET foi descrita em Ferreira et al (2002).

Tanto a busca quanto o consumo de alimentos envolvem, freqüentemente, comportamentos manipulatórios complexos. Na exploração de troncos e galhos de árvores (com o aparente propósito de encontrar pontos em que a casca esteja solta devido à presença de larvas), por exemplo, observamos um comportamento que consistia de uma rápida sucessão de batidas com as pontas dos dedos. Já havíamos observado esse comportamento durante o experimento de campo descrito no capítulo anterior (Perondi, Izar \& Ottoni, 1995), na exploração de uma caixa contendo melado; ele se parece muito com o que Erickson et al (1998) chamaram de "forrageamento percussivo" no comportamento exploratório dos aie-aies (Daubentonia madagascariensis), que possuem um dedo altamente especializado para esta função.

\subsubsection{A quebra de cocos}

Uma fêmea adulta foi observada, em duas ocasiões, arrancando um coco 
verde de jerivá, batendo-o repetidamente contra um tronco de árvore, descascando o epicarpo de uma extremidade do coco com a boca, fazendo nele um furo com um dente canino e bebendo o endosperma líquido. Mas o consumo do endosperma sólido dos frutos maduros requer procedimentos bem mais elaborados.

Os cocos maduros costumam ser quebrados com a ajuda de duas pedras, uma com uma superfície horizontal, disposta sobre o substrato (a "bigorna") e a outra menor, segura nas mãos (o "martelo"). Em algumas ocasiões, a "bigorna" era uma raiz ou um pedaço de pavimento cimentado, e um pedaço de madeira foi usado, uma vez, como "martelo". Os "martelos" são em geral seguros com ambas as mãos (parecem bastante pesados para os animais), erguidos rapidamente ao nível da cabeça e então golpeados contra o coco posicionado sobre a "bigorna". A cauda se apóia firmemente contra o chão, atuando com um terceiro ponto de apoio (Figura 4). Em algumas ocasiões, o macaco chega a pular (retirando os pés do chão) na fase ascendente do movimento - mas a ponta da cauda se mantém em contato com o solo. Se o golpear envolve principalmente força e equilíbrio corporal, o posicionamento do coco sobre a "bigorna", entretanto, requer uma manipulação fina e cuidadosa (Figura 5), especialmente em "bigornas" inclinadas.

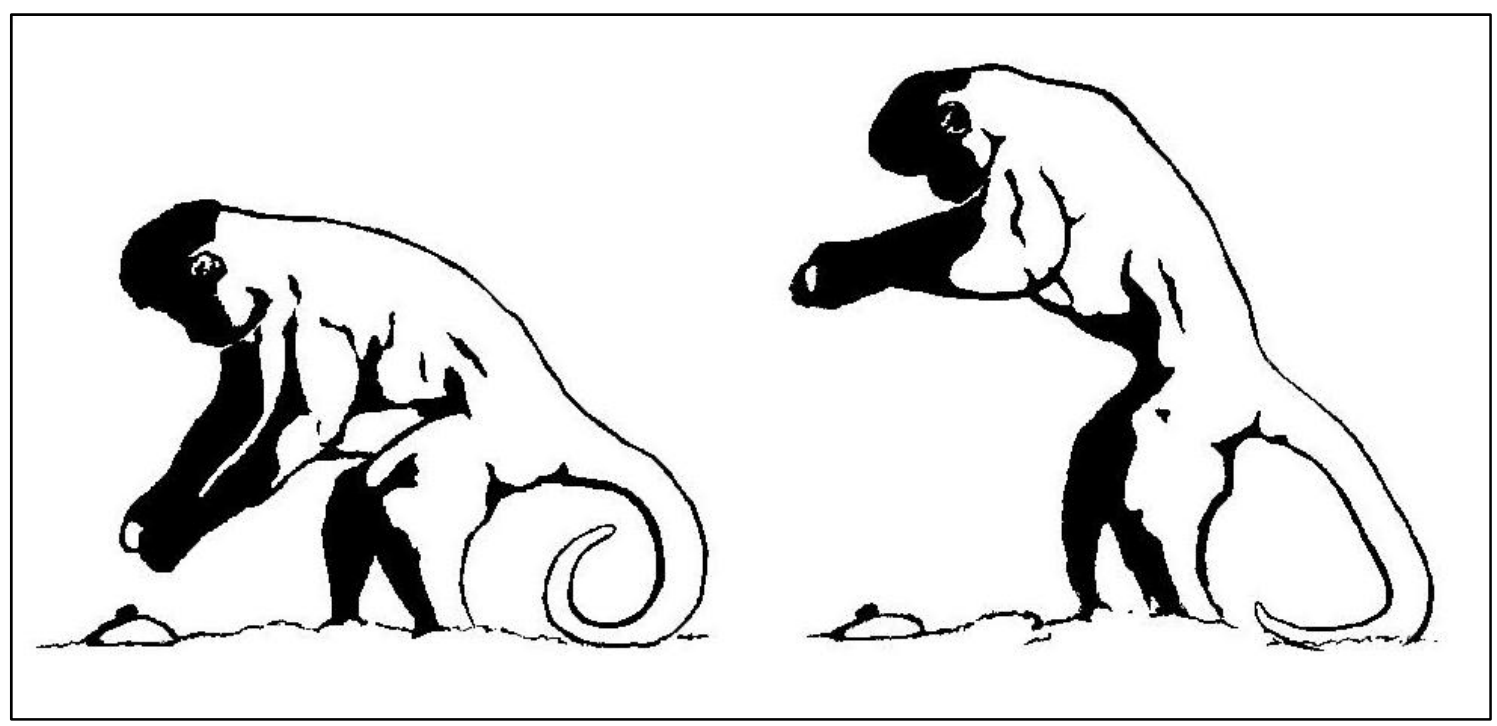

Figura 4. Posturas na quebra de cocos (ilustração E.B. Ottoni baseada em vídeo de M. Mannu). 


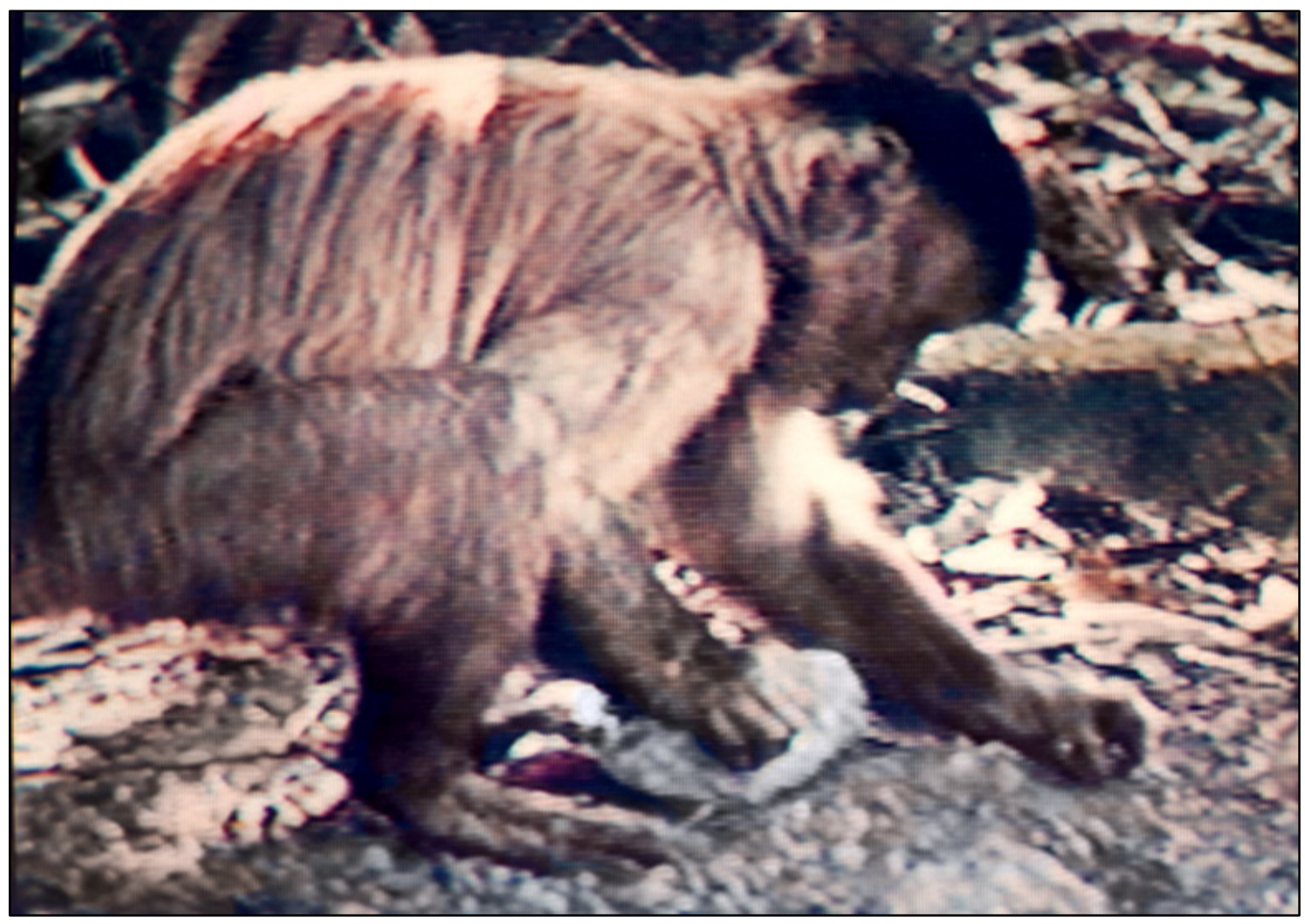

Figura 5. Medeiros posicionando coco para quebrá-lo, num dos primeiros registros filmados do comportamento no PET (vídeo M. Mannu).

\subsubsection{Os sítios de quebra de cocos}

Definimos como "sítios de quebra" quaisquer conjuntos de "martelo" e "bigorna" cujo uso na quebra de cocos tivesse sido diretamente observado ou inferido a partir dos restos de cocos e marcas (arranhões) nas pedras. Uma vez que as "bigornas" são, em geral, de transporte difícil ou impossível, os sítios de quebra tendem a ser bastante estáveis - especialmente aqueles com "bigornas" enterradas. Por volta de julho de 1998, 136 sítios de quebra tinham sido mapeados, com uma média de 37.2 sítios (min.:15, max.:52) verificados como ativos em cada mês do período final (fevereiro a julho de 1998).

\subsubsection{A demografia da quebra de cocos}

Todos os macacos foram observados, ao menos uma vez, manipulando cocos e/ou pedras nos sítios de quebra (e todos, com a exceção de três dos quatro 
infantes, "quebraram"14 ${ }^{14} \operatorname{cocos}$ ao menos uma vez), mas as diferenças individuais e entre as classes de sexo e idade em freqüência eram muito grandes, como mostrado na Figura 6.

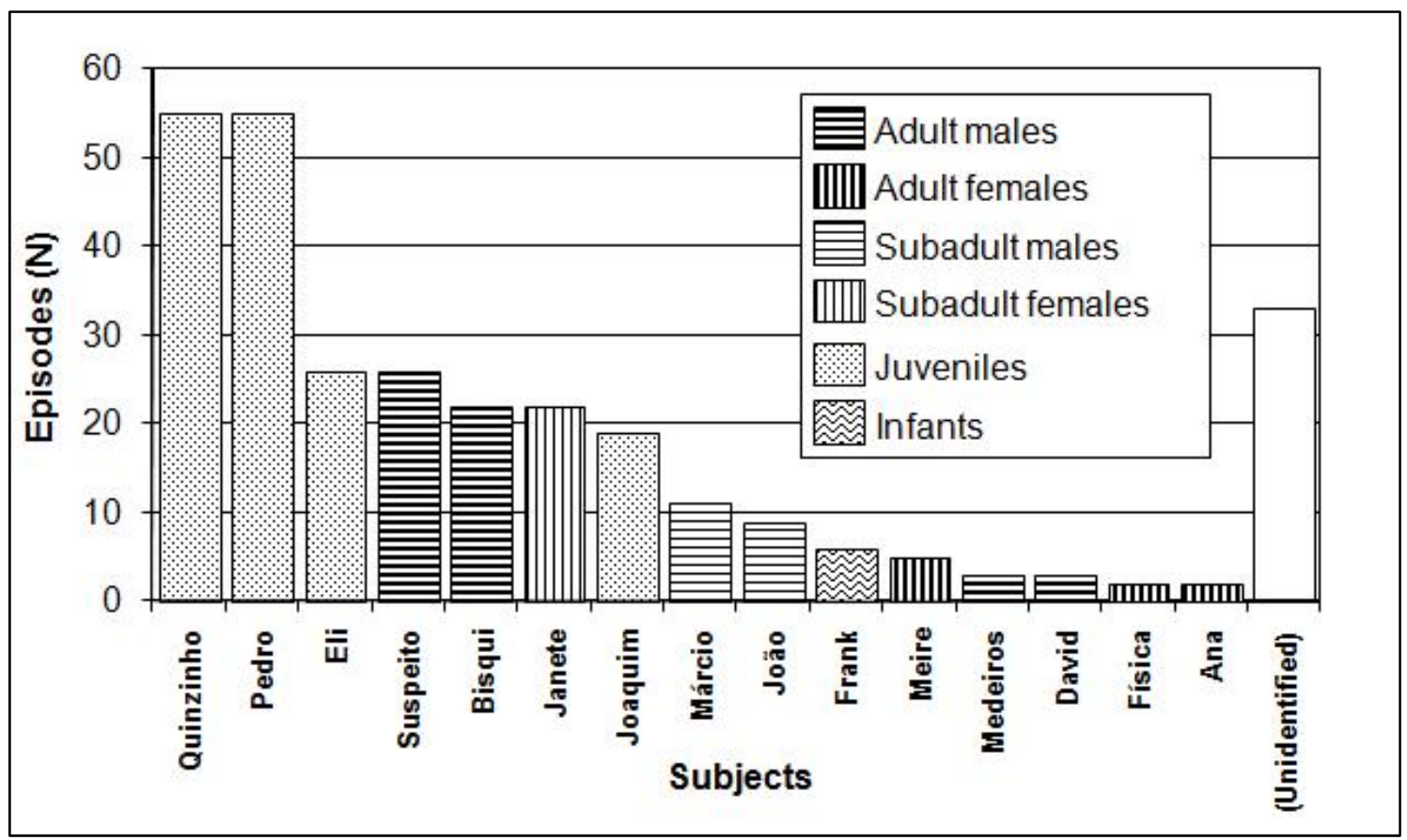

Figura 6. Freqüências individuais observadas de quebra de cocos (de Ottoni \& Mannu 2001).

Os juvenis foram responsáveis por mais da metade $(\mathrm{N}=164)$ dos episódios de quebra de cocos em que o indivíduo pode ser identificado (286 dentre 299 episódios), seguidos pelos machos adultos ( $N=54$ ), uma fêmea subadulta $^{15}(\mathrm{~N}=22)$, os machos subadultos $(\mathrm{N}=20)$, os infantes (um deles, $\mathrm{N}=15)$ e as fêmeas adultas $\left(\mathrm{N}=11 ; \chi^{2}=232.2,5\right.$ g.l., $\left.\mathrm{p}<0.0001\right)$. O número médio de episódios por indivíduo nas diferentes classes de sexo e idade está indicado na Figura 7.

As diferenças entre os sexos são menos claras que as diferenças de idade: entre os indivíduos adultos, os machos foram significativamente mais ativos que as fêmeas na quebra de cocos (goodness-of-fit, $\chi^{2}=17.86,1$ g.l., $\mathrm{p}<0.0001$ ), como havia sido observado no cativeiro por Visalberghi (1987), mas

\footnotetext{
14 I.e., exibiram a categoria comportamental "Quebrar Cocos", que incluía toda a atividade percussiva envolvendo a associação de "martelos", cocos e "bigornas".

${ }^{15}$ Janete foi descrita como "subadulta" nas primeiras publicações, mas essa classe etária não tornou a ser utilizada (no caso de fêmeas) nos estudos subseqüentes.
} 
a única fêmea subadulta, Janete, foi responsável por mais episódios de quebra que os dois machos subadultos, juntos.

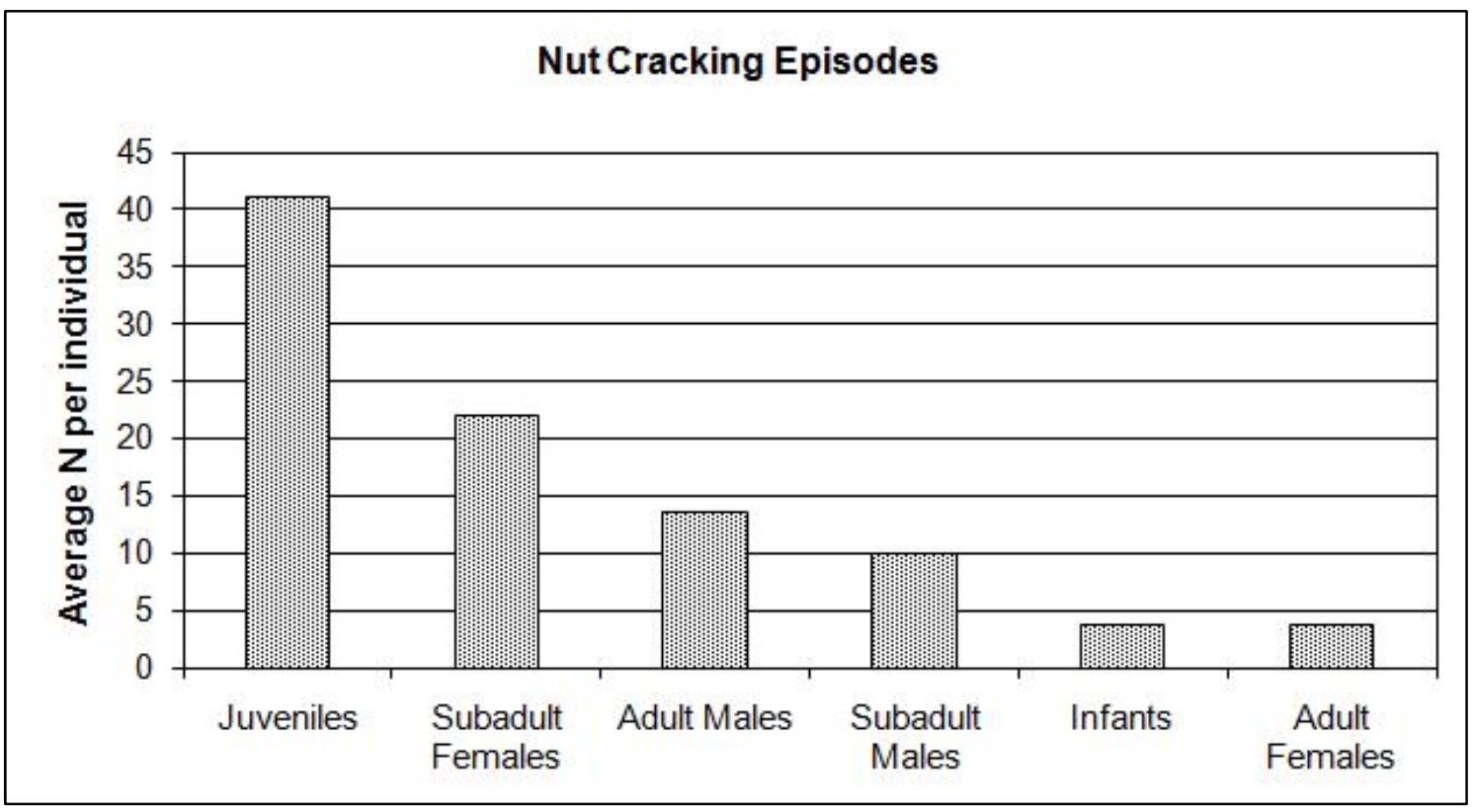

Figura 7. Número médio de episódios de quebra de cocos por indivíduo em cada classe de sexoidade (de Ottoni \& Mannu 2001).

A proficiência na quebra de cocos, por outro lado, mostrava um padrão um pouco diferente. Ao examinarmos a proporção de episódios "proficientes" (com quebra de ao menos 1 coco) para cada faixa etária, verificamos que, nesta fase da coleta de dados, os subadultos foram um pouco mais proficientes que os adultos - e estes, mais proficientes que os juvenis (v. adiante, Figura 11).

Também foram observadas grandes diferenças individuais na proficiência dentro das classes etárias: o número de episódios de quebra de cocos bem-sucedidos (considerando-se apenas os episódios em que foi efetivamente observada a ingestão de endosperma) dividido pelo número total de episódios (X 100) resultou em uma taxa de 30\% de sucesso para Quinzinho e de $8 \%$ para Pedro.

\subsubsection{A observação da quebra de cocos por coespecíficos}

Tornou-se logo evidente que os episódios de quebra de cocos constituíam uma 
oportunidade potencial para alguma forma de aprendizagem observacional: cerca de $17 \%$ deles $(\mathrm{N}=52)$ foram observados, de no máximo 1 metro de distância, por outro(s) indivíduos (2 observadores simultâneos: $N=6$; três observadores simultâneos, $\mathrm{N}=2$ ). Em alguns destes eventos, os observadores infantes ou juvenis (em geral após a partida do "quebrador") manipulavam as pedras ou comiam restos de coco no sítio de quebra.

Os "quebradores" que foram alvo de observação por coespecíficos eram juvenis $(\mathrm{N}=18)$, adultos $(\mathrm{N}=17)$, subadultos $(\mathrm{N}=10)$, o infante Frank $(\mathrm{N}=5)$ e 2 indivíduos não identificados. O número médio de ocorrências por indivíduo nas diferentes classes etárias está indicado na Figura 8. Os observadores eram infantes $(\mathrm{N}=24)$, juvenis $(\mathrm{N}=21)$, subadultos $(\mathrm{N}=8)$ ou adultos $(\mathrm{N}=6 ; 3$ observadores não identificados; $\chi^{2}=26.75,3$ g.l., p<0.0001). Os valores médios por indivíduo nas diferentes classes etárias mostraram que a observação era uma principalmente uma atividade de indivíduos mais jovens. Isto poderia se dever a uma maior atividade exploratória ou a uma maior tolerância dos "quebradores" à sua presença.

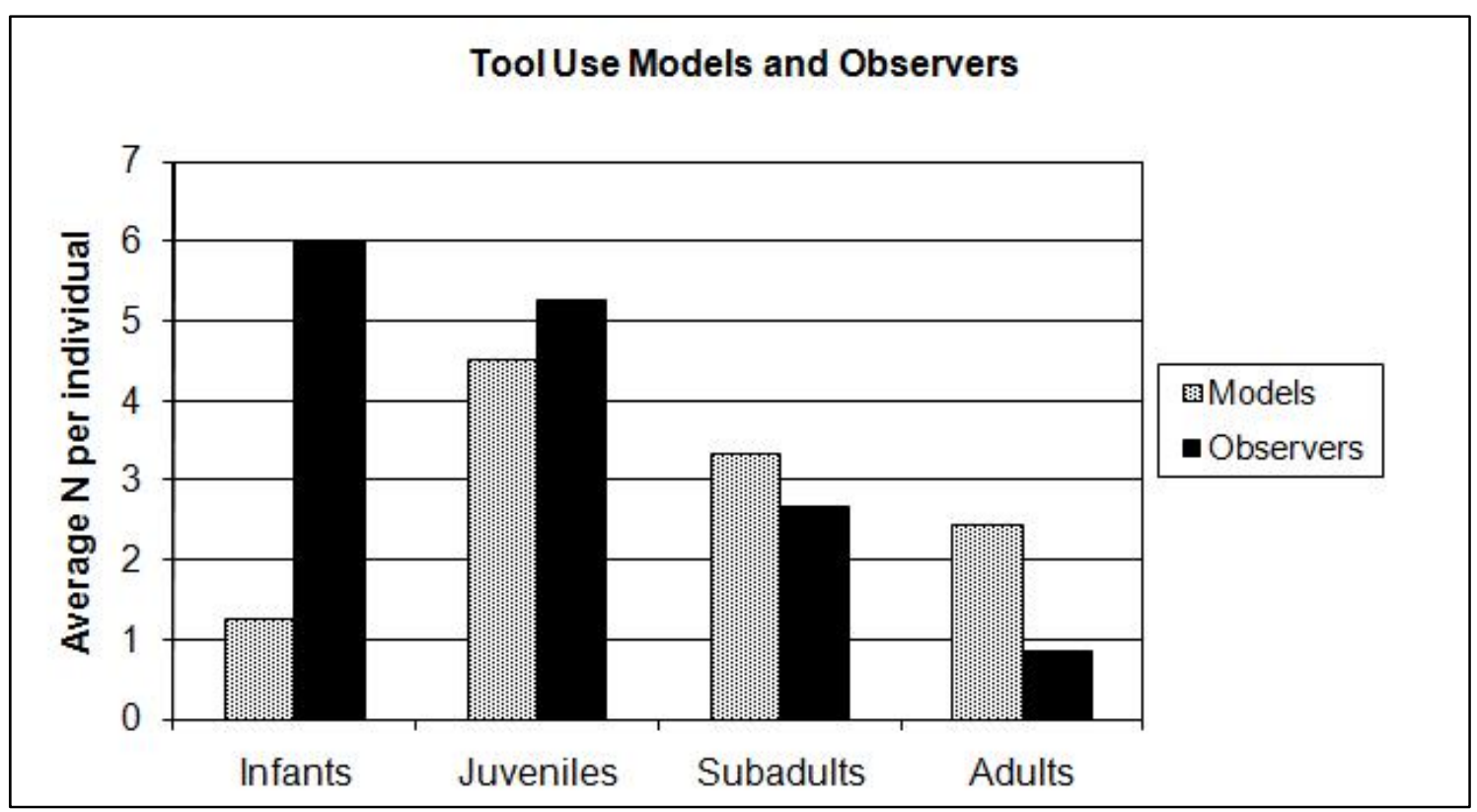

Figura 8. Observadores e "quebradores" observados nas classes etárias (de Ottoni \& Mannu 2001).

Por outro lado, adultos que se aproximam tendem a deslocar os animais mais jovens, tornando-se observadores menos prováveis de episódios de quebra. No contexto do experimento sobre uso induzido de ferramentas 
(Perondi, Izar \& Ottoni 1995), observamos que a chegada de machos adultos ao aparato em geral interrompia a atividade manipulatória de subadultos e juvenis - o que poderia constituir uma barreira séria para a transferência social de informação entre estas classes de sexo/idade.

\subsubsection{A manipulação "inepta" de "martelos" e "bigornas"}

Classificamos trinta e oito episódios de manipulação de pedras (não incluídos nas análises anteriores) como ineptos ${ }^{16}$, por envolverem um procedimento de quebra errado (não-produtivo), algo muito semelhante ao que Visalberghi (1987) observou em um experimento com macacos-prego cativos, e Matsuzawa (1994) e Inoue-Nakamura \& Matsuzawa (1997) relataram em infantes de chimpanzés selvagens: em alguns casos, o "martelo" era golpeado contra a "bigorna" - sem um coco; em outros, o sujeito apenas se aproximava de um sítio de quebra, manipulava o "martelo" por alguns instantes e se afastava.

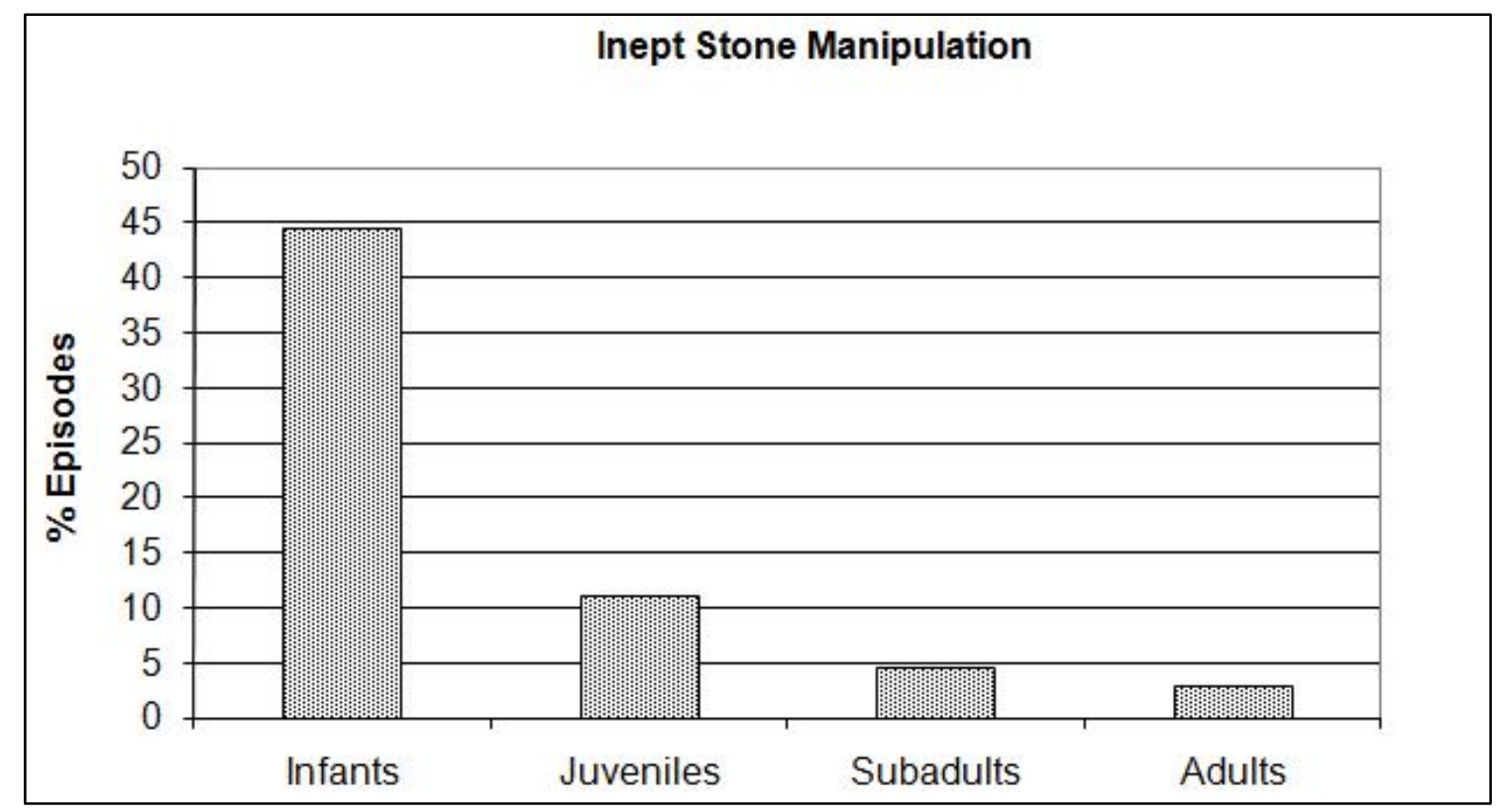

Figura 9. Proporção de episódios de manipulação inepta de pedras no número total de episódios de manipulação em cada classe etária (de Ottoni \& Mannu 2001).

A prevalência dos juvenis $(N=21)$ na freqüência absoluta de episódios de

${ }^{16}$ Esta "categoria" foi reconsiderada em estudos subseqüentes (v. adiante, Capítulo 3). 
manipulação inepta era esperada, já que eles eram os "quebradores" mais ativos (infantes, $\mathrm{N}=12$; subadultos, $\mathrm{N}=2$; adultos, $\mathrm{N}=2$; não identificado, $\mathrm{N}=1$ ), mas dividindo estes valores pelo número total de episódios de manipulação de "martelos" e "bigornas" ( $n=347$ : quebra de cocos [n=299] + quebra de outros frutos $[n=10]+$ manipulação inepta $[n=38])$, obtivemos os valores proporcionais mostrados na Figura 9. Estes resultados indicam uma queda gradual, com a idade, na taxa de manipulação inepta (goodness-of-fit: $\chi^{2}=39.04,3$ g.l., $\mathrm{p}<0.0001)$.

\subsection{Segunda fase da coleta de dados}

Já na condição de aluno de Mestrado, Massimo Mannu deu início a uma segunda fase da coleta de dados por observação direta dos animais (novembro de 1998 a dezembro de 1999; Mannu 2002). O registro de "Todas as Ocorrências" de quebra de cocos foi mantido, mas passamos a utilizar também o método do "Animal Focal" (Martin \& Bateson 1993). Essa subdivisão das fases da coleta se deu, também, em função da mudança de faixa etária de onze sujeitos, de acordo com os critérios que haviam sido inicialmente definidos.

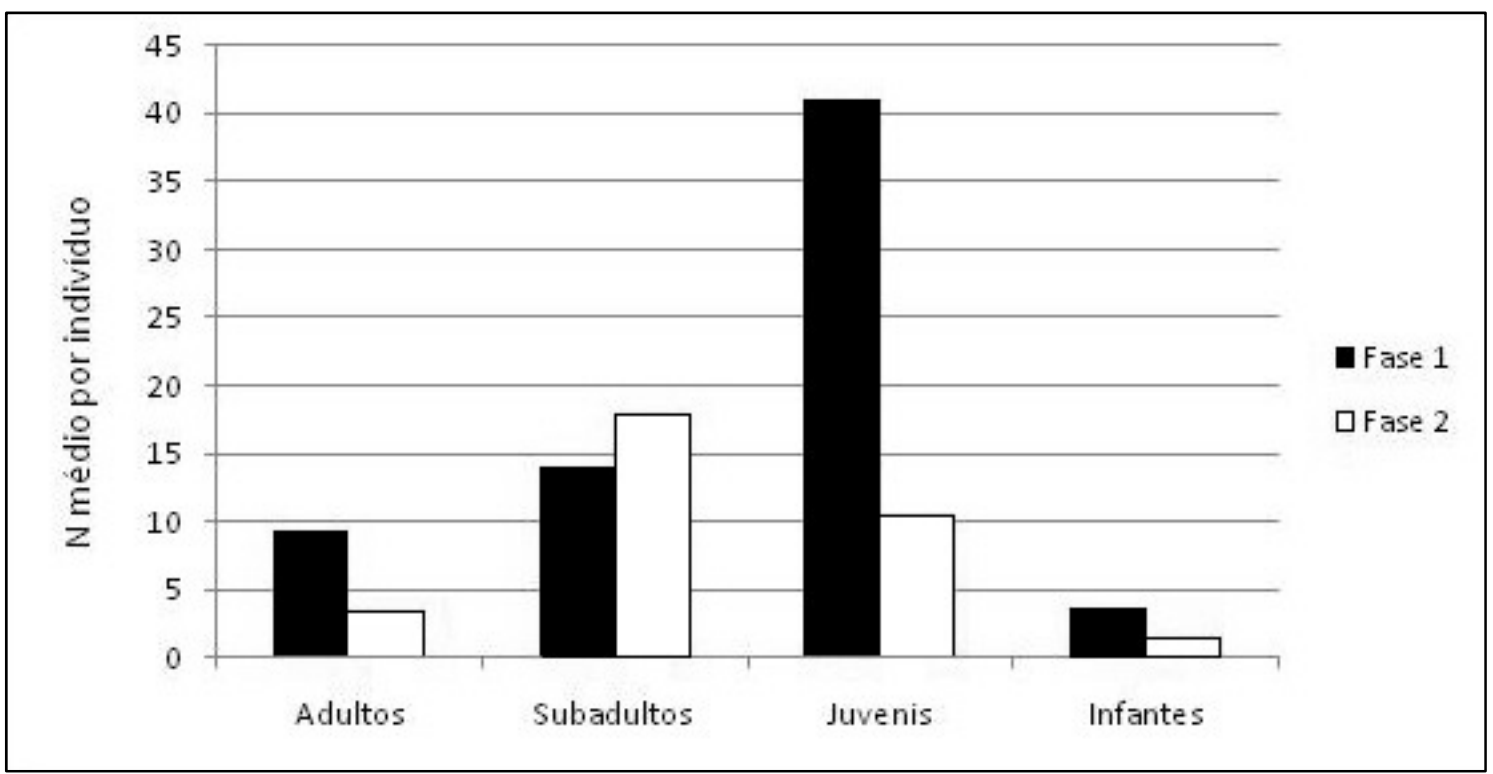

Figura 10. Freqüência relativa dos episódios adequados de quebra de cocos nos dois períodos de coleta de dados pelo método de "Todas as Ocorrências": total de episódios dividido pelo total de indivíduos de cada classe etária (de Mannu 2002). 
Nesta fase (quando o grupo contava com 22 indivíduos), 16 indivíduos quebraram cocos adequadamente ao longo de 255 horas de observação, mas os machos subadultos - que eram os juvenis da primeira fase - foram responsáveis por quase metade $(\mathrm{N}=72)$ dos episódios de quebra em que o sujeito pode ser reconhecido ( $\mathrm{N}=154$, de um total de 166 episódios registrados), e desapareceram as diferenças significativas entre as faixas etárias (Figura 10).

A freqüência relativa de episódios "proficientes" (com quebra efetiva de cocos) registrados pelo método de "Todas as Ocorrências" (Figura 11), nesta fase, se mostrou progressivamente maior quanto mais elevada a faixa etária.

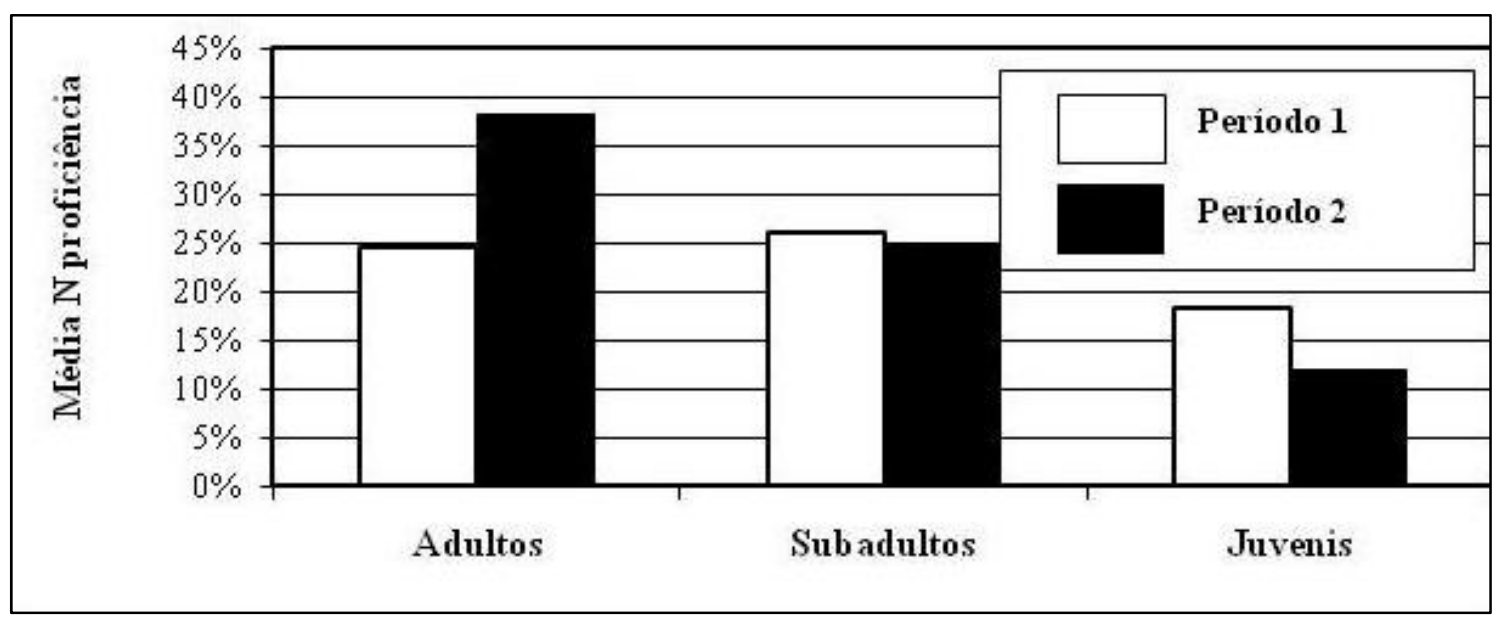

Figura 11. Freqüência relativa de episódios proficientes de quebra de cocos por faixa etária nos diária nos dois períodos da coleta de dados pelo método de "Todas as Ocorrências" (N episódios com consumo de endosperma / total de episódios X 100) (de Mannu 2002).

Essas mudanças na demografia da quebra de cocos se refletiram também na observação do comportamento por outros macacos. Na segunda fase, 11\% dos episódios registrados foram observados por coespecíficos: os "alvos" de observação foram subadultos $(\mathrm{N}=8)$, adultos $(\mathrm{N}=7)$ e juvenis $(\mathrm{N}=3)$, enquanto que os observadores foram infantes $(\mathrm{N}=9)$, adultos $(\mathrm{N}=6)$, juvenis $(\mathrm{N}=3)$ e subadultos $(\mathrm{N}=1)$. A Figura 12 mostra a média individual de episódios de observação por classe etária ("Todas as Ocorrências"). Na distribuição dos "alvos", os subadultos passaram a predominar, com a mudança de faixa etária dos juvenis da fase anterior.

Nos dois períodos, ao examinarmos as díades de observação, 
verificamos que infantes eram observados apenas por outros infantes, enquanto que, para os "alvos" mais velhos, os observadores provinham de todas as faixas etárias. Analisando-se $0 \chi^{2}$ residual, verificamos que as díades de observação com freqüências significativamente acima do esperado eram aquelas em que "alvos" e observadores eram, respectivamente, adultos/juvenis, adultos/infantes, subadultos/infantes, juvenis/juvenis e juvenis/infantes.

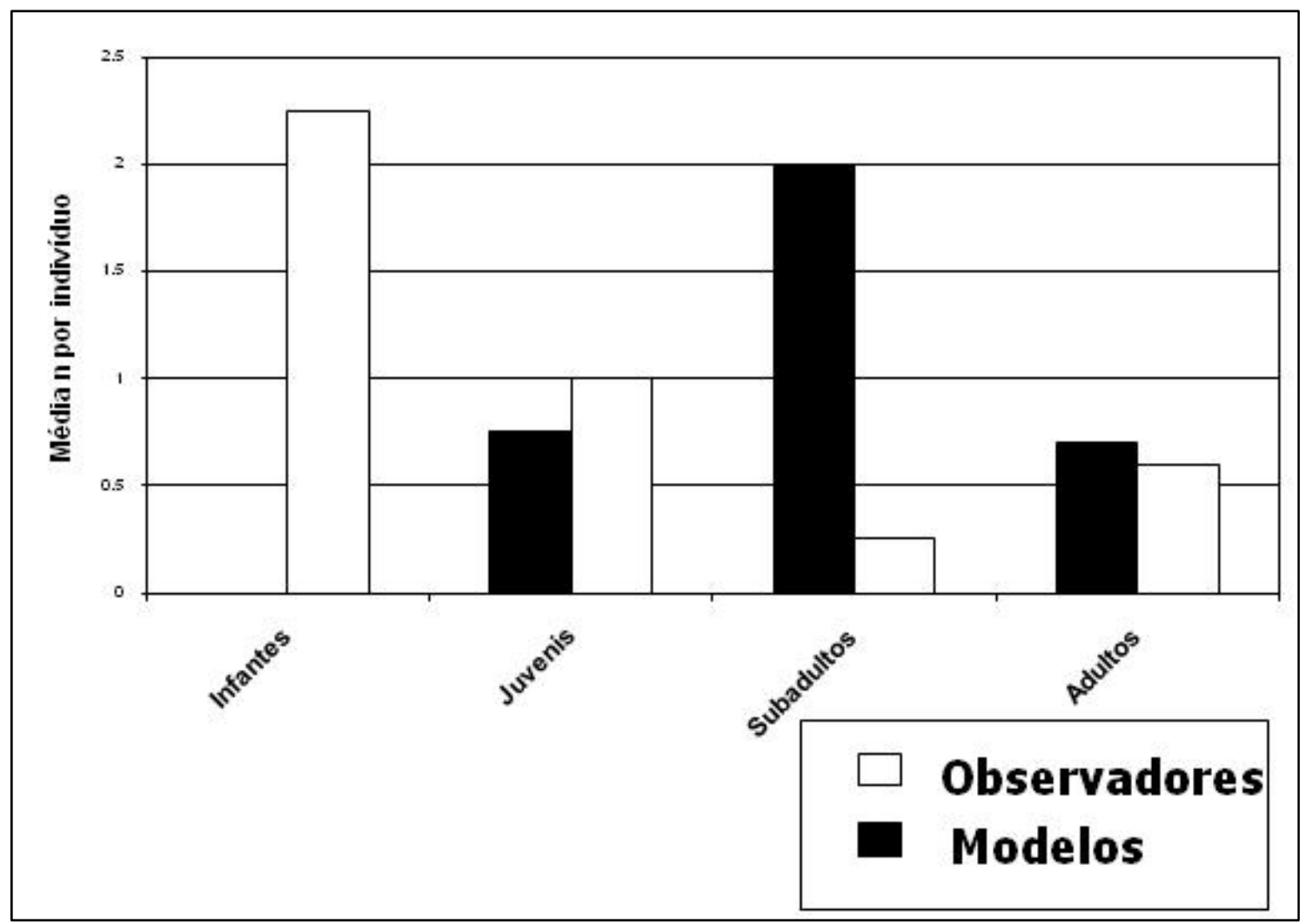

Figura 12. Modelos e observadores na quebra de cocos no $2^{\circ}$ período da coleta de dados, pelo método de "Todas as Ocorrências"; total de episódios com observação dividido pelo total de indivíduos em cada faixa etária (de Mannu 2002).

\subsubsection{Observações pelo método do "Animal Focal"}

Foram realizadas 738 observações focais (de 10 minutos), com duração total efetiva (descontados os períodos com animais "fora de visão") de 117h50'. O tempo gasto pelos animais na quebra de cocos correspondeu a $1.12 \%$ do tempo de amostragem focal. Registramos 59 episódios de "quebra adequada", 
envolvendo 13 dos 20 sujeitos amostrados. Três dos machos subadultos foram responsáveis por 23 episódios (o quarto não foi observado nesta atividade nas amostragens focais), seguidos por 2 juvenis $(\mathrm{N}=20)$, cinco machos adultos $(\mathrm{N}=11)$, duas das fêmeas adultas $(\mathrm{N}=4)$ e um infante $(\mathrm{N}=1)$. Em 32 dos 59 episódios "adequados" observados houve quebra efetiva de pelo menos 1 coco (episódios "proficientes"), num total de 41 cocos quebrados.

Em alguns casos, além da ingestão de endosperma, os macacos consumiram larvas de insetos presentes nos cocos. Rocha, Reis e Sekiama (1998) sugeriram que este seria o principal motivo pelo qual os macacos-prego predariam os cocos de jerivá. Numa amostra de 198 cocos recolhidos em cinco locais diferentes da área de uso do grupo, encontramos a presença de larvas em apenas 7.58\% (Mannu 2002), o que nos levou a crer que, embora as larvas possam certamente constituir um "bônus" importante, o endosperma é suficientemente atraente por si só.

Foi grande a variação individual na proficiência, se medida pela média de cocos consumidos por observação focal (Figura 13); por outro lado, levando-se em conta a razão entre o número de cocos consumidos e o número de episódios "adequados" (Figura 14), Medeiros, um dos machos adultos "fundadores", se destacava de todo o restante do grupo.

Além de executarem mais episódios "adequados", os machos se mostraram mais proficientes que as fêmeas na proporção de cocos consumidos, tanto em relação ao número de episódios por observação focal, quanto aos totais de episódios "adequados" ou "proficientes" (Figura 15). 


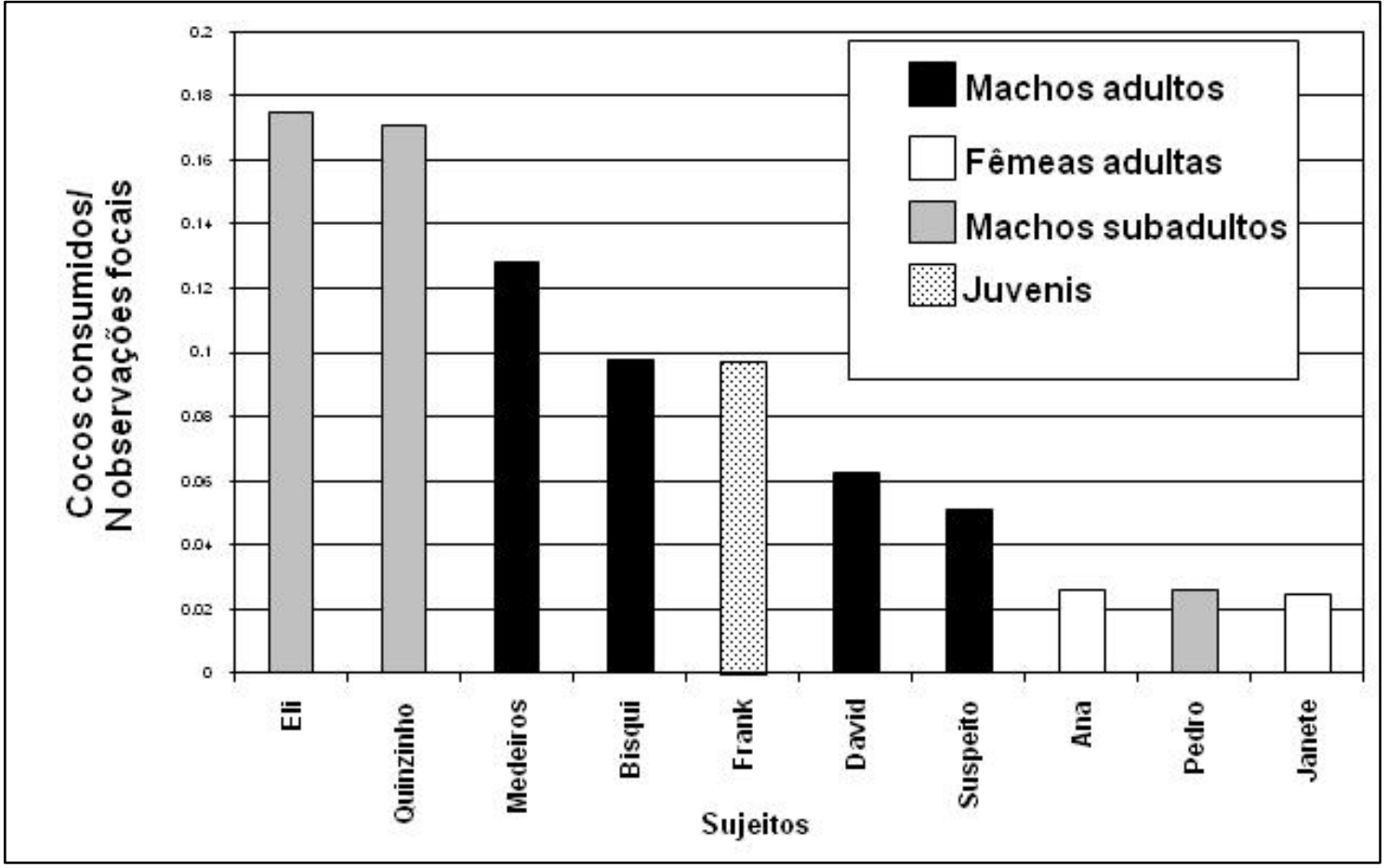

Figura 13. Proficiência média dos indivíduos: total de cocos com o endosperma consumido dividido pelo total de observações focais para cada sujeito (de Mannu 2002).

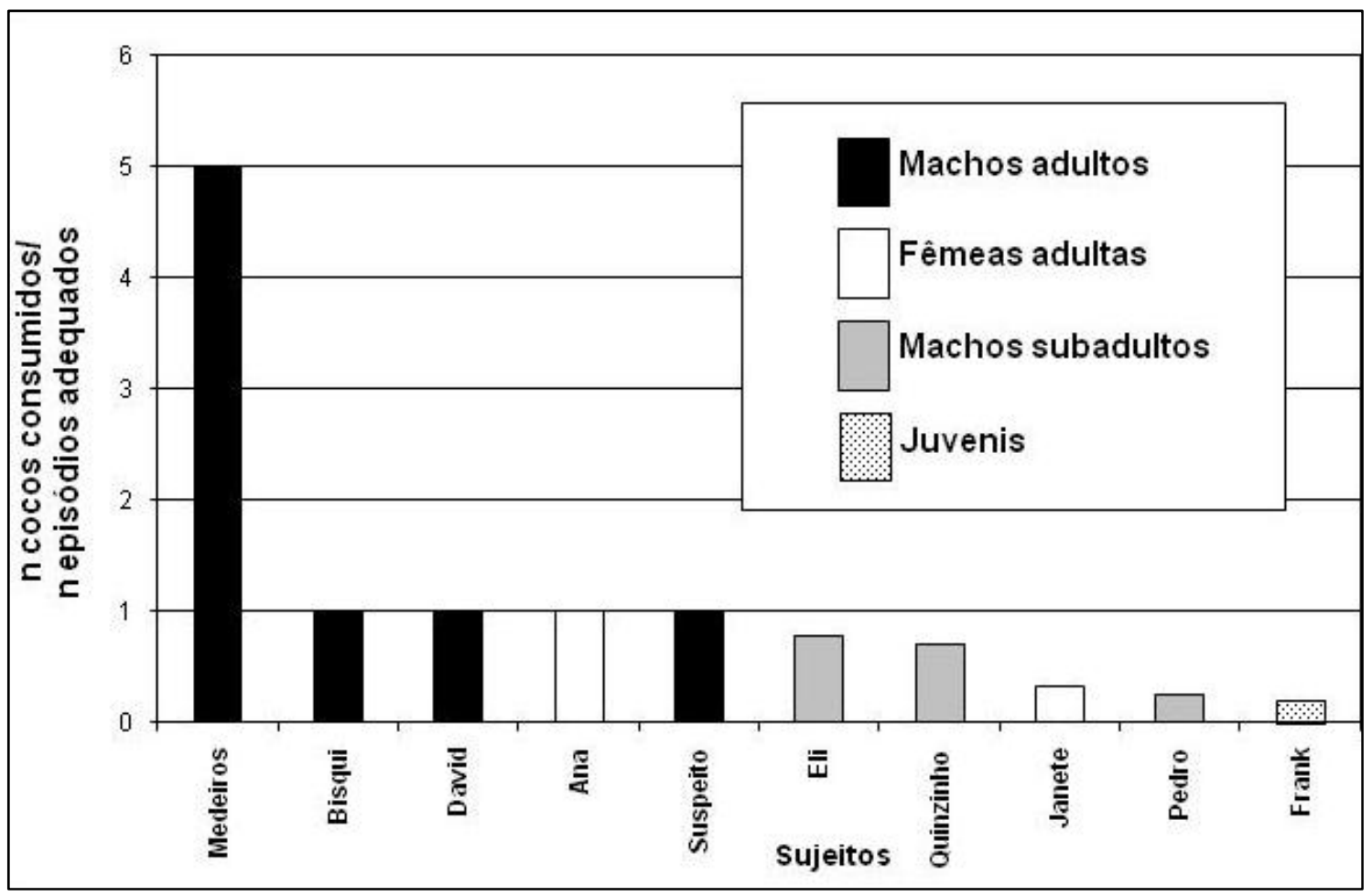

Figura 14. Proficiência média dos indivíduos: total de cocos com o endosperma consumido dividido pelo total de episódios adequados para cada sujeito nas observações focais (de Mannu 2002). 


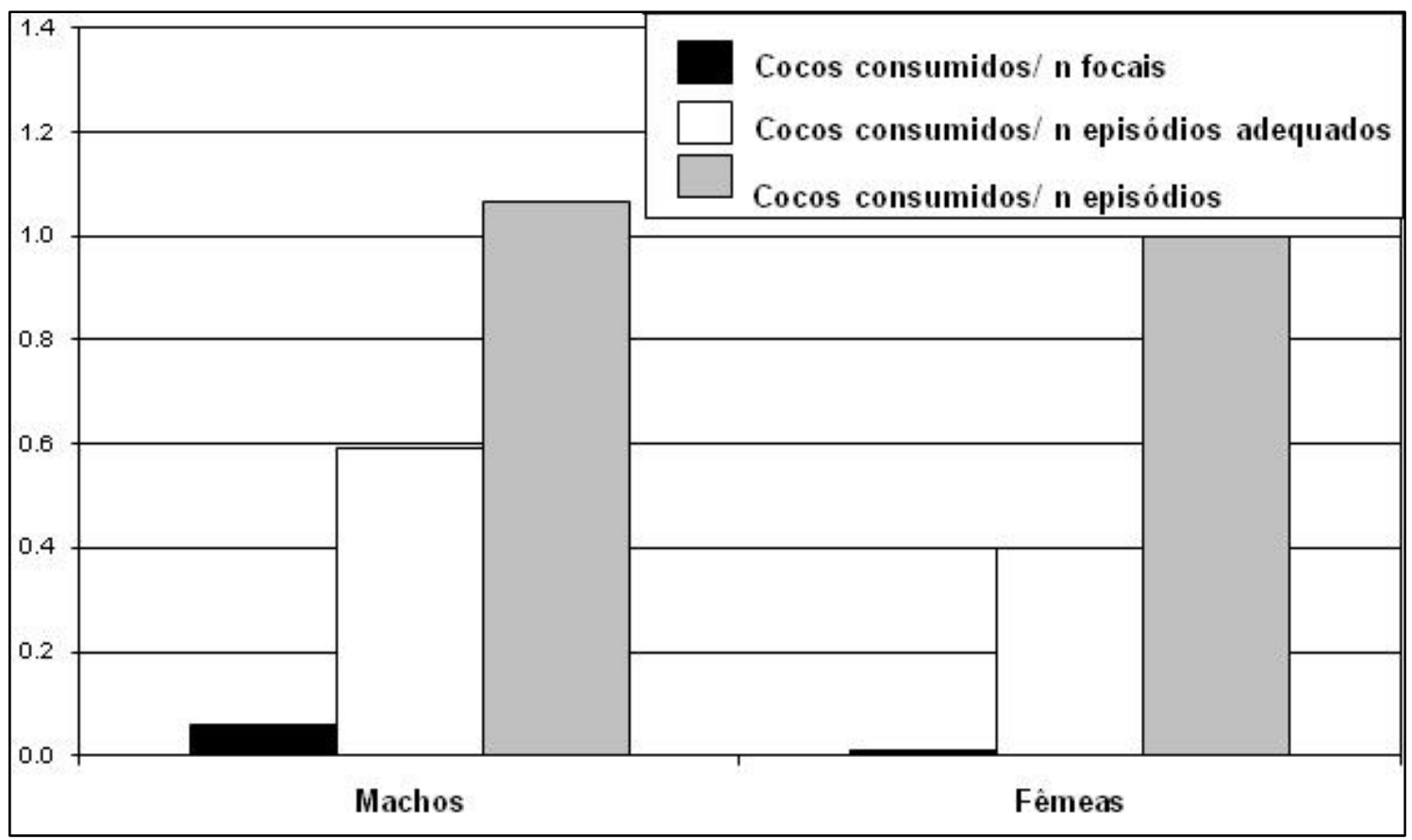

Figura 15. Proficiência média dos indivíduos: total de cocos com o endosperma consumido dividido pelo total de observações focais, total de episódios adequados e total de episódios proficientes (coco maduro + podre) para cada sexo (de Mannu 2002).

Em 11 das 738 observações focais, (1.5\% do total), os sujeitos participaram de episódios de quebra em que houve observação de coespecíficos, como "quebradores" observados ( $\mathrm{N}=7$ ) e/ou como observadores da quebra $(\mathrm{N}=10)$. Como também verificado pela amostragem de "Todas as Ocorrências", ao dividirmos os totais de episódios "adequados" em que os modelos e observadores eram os sujeitos focais pelo total de focais para cada faixa etária, verificamos que infantes e juvenis eram mais observadores que observados, e que adultos eram mais freqüentemente observados (Figura 16), embora (talvez em função do pequeno tamanho da amostra) as diferenças não tenham se mostrado significativas (Kruskal-Wallis). Analisando apenas a duração proporcional de observação de episódios adequados por coespecíficos das diferentes faixas etárias, dividindo-se a duração total de episódios "adequados" observados pelo tempo total efetivo das observações focais, constatamos, mais uma vez, que os adultos tendem a ser modelos preferenciais (nesta análise, os juvenis foram os observadores mais intensivos; Figura 17). 


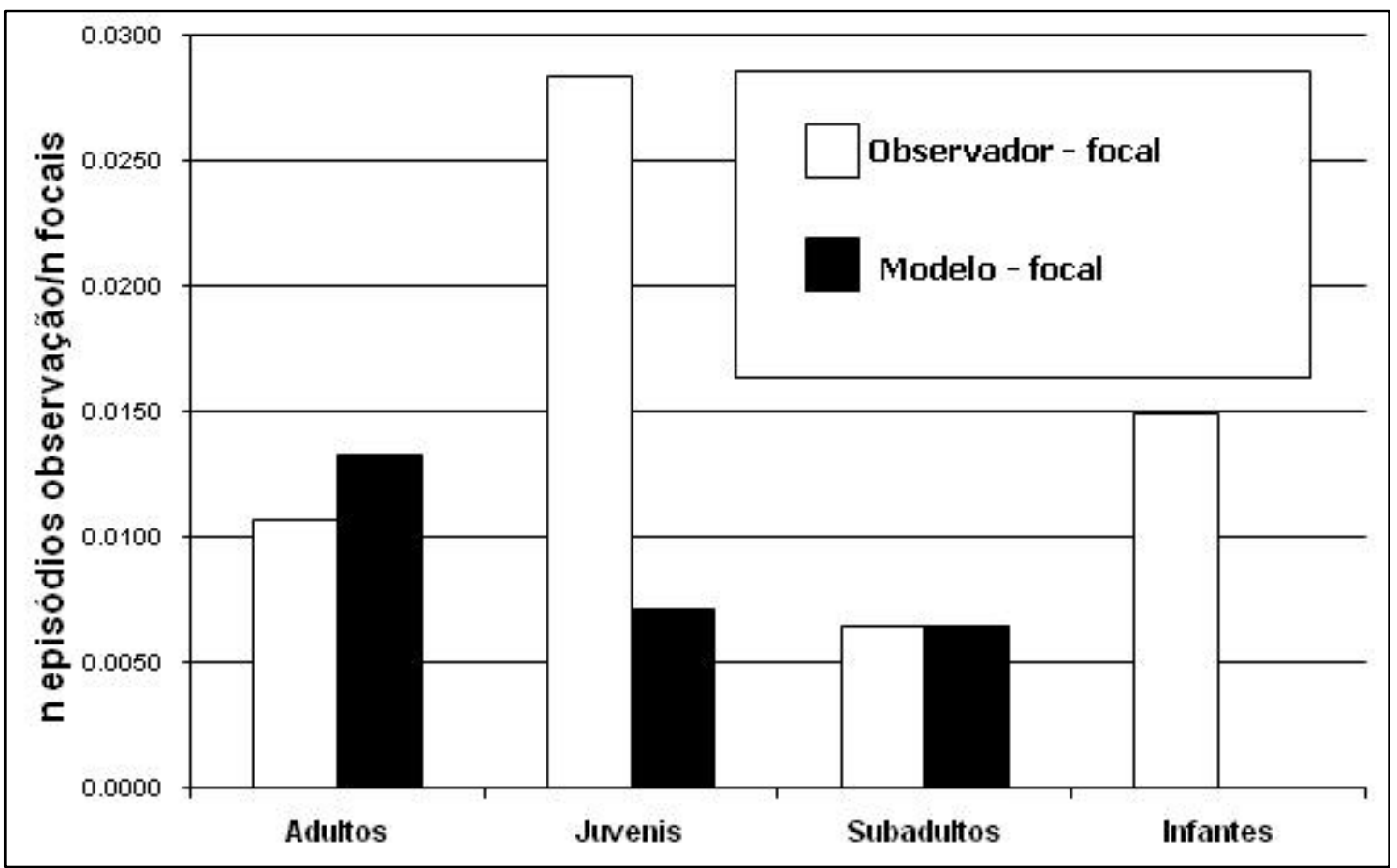

Figura 16. Modelos e observadores na quebra de cocos ("Animal Focal"): totais de episódios de observação de uso de ferramenta (quando o observador ou o modelo são os sujeitos focais) divididos pelo total das observações focais para cada faixa etária (de Mannu 2002).

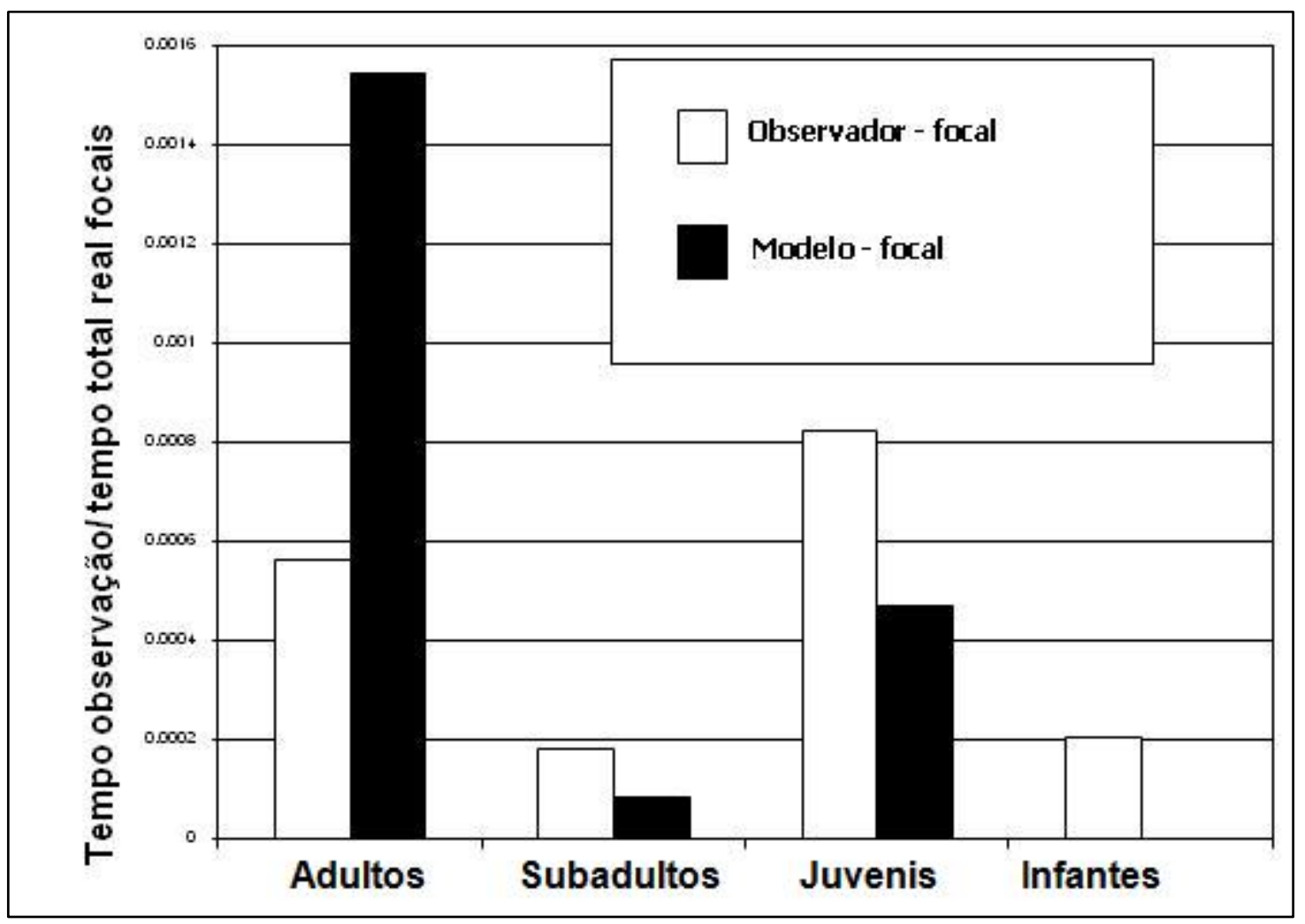

Figura 17. Proporção do tempo gasto na observação de episódios de quebra de cocos; tempo de observação dos episódios dividido pelo tempo total real (descontando o tempo em que o sujeito estava fora da visão do observador) das observações focais para cada faixa etária (de Mannu 2002). 


\subsection{Constituição e localização dos sítios de quebra}

Ao final da coleta de dados, em fevereiro de 1999, haviam sido mapeados 154 sítios de quebra (Figura 18), dos quais 63 em condições de uso (i.e., com "martelos" disponíveis sobre as "bigornas").

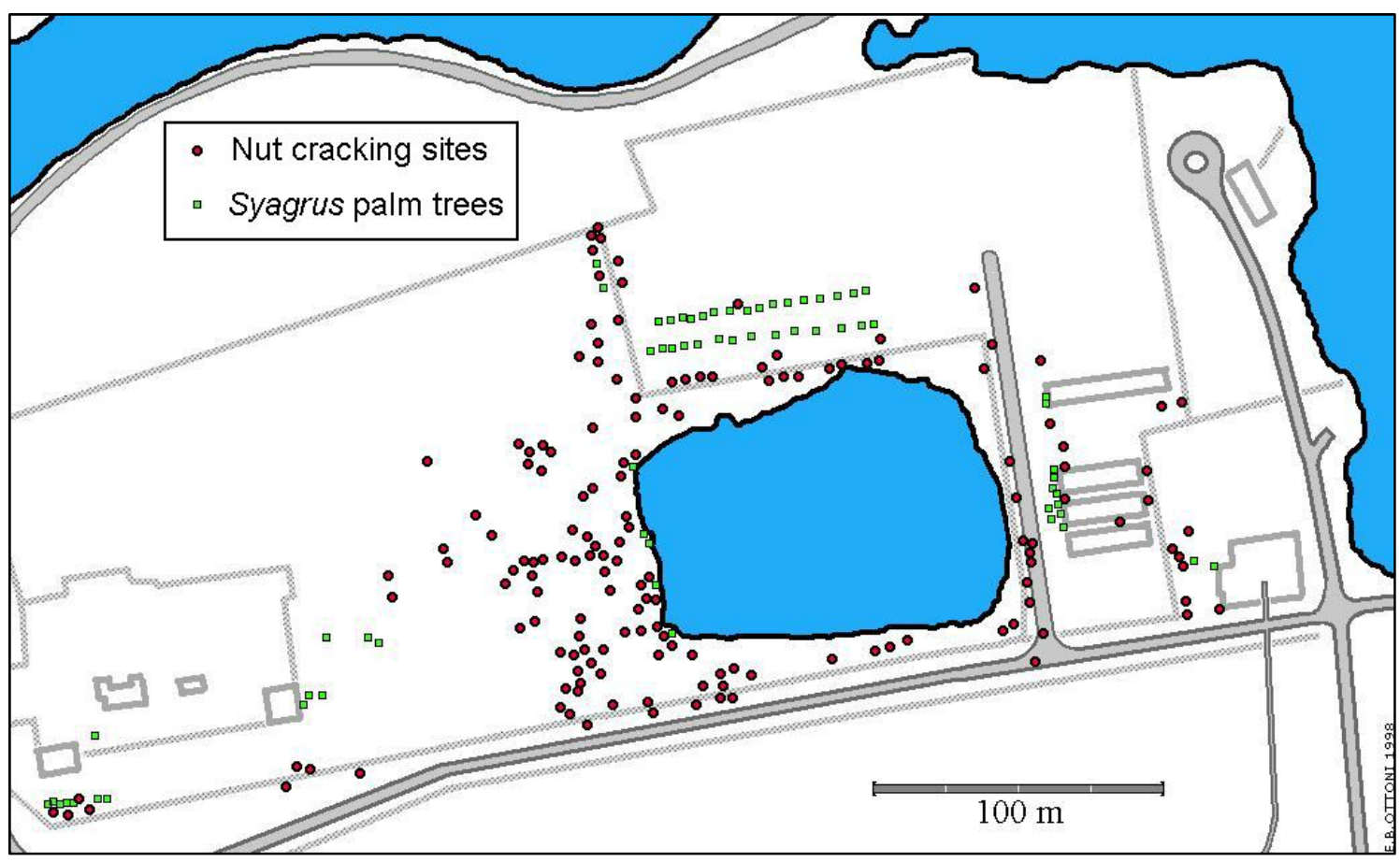

Figura 18. Distribuição dos Sítios de Quebra de cocos na Área de Preservação do PET.

Os "martelos", com duas únicas exceções (pedaços de madeira), consistiam de pedras. Ocasionalmente, foi observado o transporte destas pedras dos sítios - às vezes, para quebrar cocos em lugares mais altos (talvez por causa da presença do observador), o que nos levou a crer que pedras encontradas em locais elevados, como telhados ou o topo dos moirões das cercas fossem, igualmente, resultado do transporte pelos macacos. As "bigornas" eram mais diversificadas e foram classificadas de acordo com seu material, sua inclinação e seu posicionamento no substrato. A maioria das 154 "bigornas" monitoradas era de pedras soltas $(\mathrm{N}=58)$, pequenas ou grandes, de superfície plana ou quase, pedras enterradas de superfície mais irregular $(N=29)$, cilindros de cimento (reforços da base das cercas) e sapatas dos moirões das cercas $(\mathrm{N}=21)$ ou constituída por pisos ou blocos de cimento de 
áreas com calçamento $(\mathrm{N}=17)$. Doze "bigornas" possuíam uma superfície inclinada (tronco, raiz, cilindro de cimento na horizontal).

Quanto à distribuição espacial dos sítios de quebra, verificamos que havia uma densidade máxima destes entre 10 e 20 metros de distância da palmeira de jerivá mais próxima, e que, a partir daí, a freqüência absoluta de sítios declinava gradualmente com a distância (Figura 19). Uma análise de regressão foi empregada para examinar a hipótese de que os sítios mais próximos das palmeiras seriam os mais intensamente utilizados e foram, efetivamente, encontradas correlações inversas significativas entre a distância do sítio à palmeira mais próxima e as freqüências absoluta e relativa de uso dos sítios, bem como entre esta distância e as quantidades absoluta e relativa de cocos quebrados por sítio ("relativa", nestes casos, se refere à divisão dos valores absolutos pelo $\mathrm{N}$ total de semanas de existência do sítio; Mannu \& Ottoni 2000).

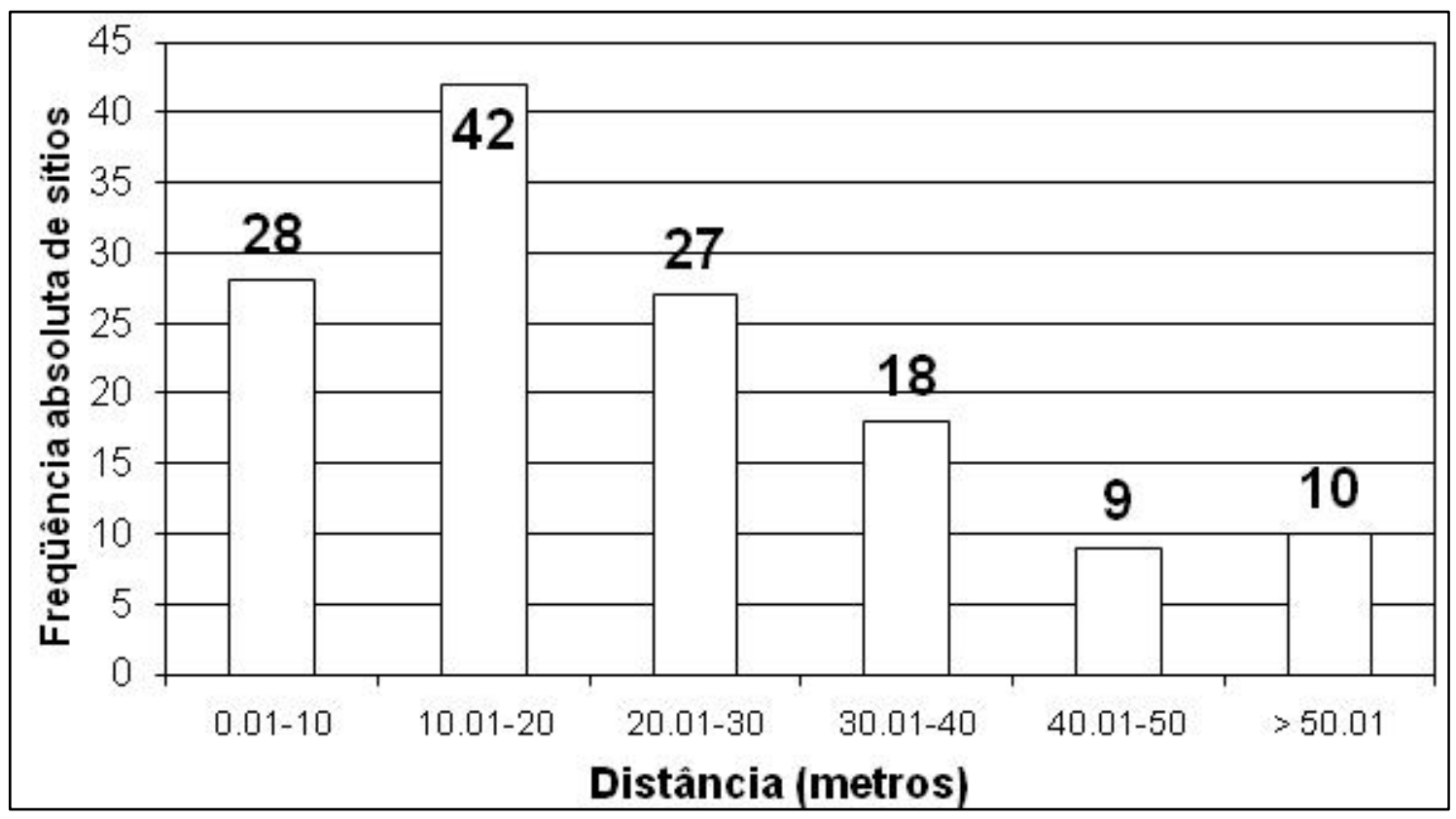

Figura 19. Freqüência absoluta de sítios usados para a quebra de cocos pela distância da palmeira de jerivá mais próxima (Mannu \& Ottoni 2000).

\subsection{Terrestrialidade, bipedalismo e transporte de objetos}

Em um estudo-piloto (Silva, Resende \& Ottoni 2000) examinamos a freqüência e os contextos de ocorrência de uso do solo e do deslocamento bipedal no 
grupo de macacos-prego da Área de Preservação do PET.

Dez "varreduras" (Altmann 1974) diárias foram realizadas durante oito dias. Os eventos comportamentais foram subdivididos em duas categorias espaciais, "solo" e "não-solo". Observamos uma menor freqüência de repouso e uma maior freqüência de interações sociais no solo (envolvendo exclusivamente registros de brincadeira). Fora do solo, houve um equilíbrio entre brincadeira e catação - e um único episódio agonístico.

Registramos uma maior freqüência de uso do solo por juvenis (24\%), em relação a adultos/subadultos (16\%) e infantes (14\%). Os juvenis foram responsáveis pela maioria dos registros de deslocamento bípede; a maioria dos deslocamentos quadrúpedes foram realizados por adultos/subadultos.

Os deslocamentos no solo foram mais freqüentes em áreas mais abertas do parque. As categorias analisadas foram: quadrúpede (solitário/acompanhado) e bípede (com/sem carga). Os deslocamentos quadrúpedes acompanhados envolveram exclusivamente díades adulto-infante. Todos os deslocamentos bípedes registrados nas varreduras envolveram transporte de objetos (mas deslocamentos bípedes sem carga foram observados ad libitum). Embora naturalmente o bipedalismo seja uma postura de deslocamento predominantemente terrestre, foram observadas, fora dos registros, algumas ocorrências fora do solo.

Em 2003, tornamos a examinar, neste grupo, o uso do solo e da postura bípede no transporte de objetos. O método utilizado foi o do "Animal Focal", sendo registrados os comportamentos, a postura e o substrato ("solo", "largo" e "estreito"). O uso do solo ocorreu em $6.25 \%$ e a adoção da postura bípede, em $0.96 \%$ do tempo total de observação (150 horas). As atividades na postura bípede foram variadas, sendo o forrageamento a mais freqüente. $O$ transporte de objetos ocorreu em $25 \%$ do tempo total em que os indivíduos foram observados nesta postura. Alimentos foram os itens mais transportados (86.5\%), tendo o uso das duas mãos predominado (Greco 2003). 


\subsection{Uso de ferramentas pelos macacos-prego do Parque do Jaraguá}

Algum tempo mais tarde, um outro estudo realizado por nossa equipe examinou a ocorrência do uso de ferramentas na quebra de cocos de jerivá em outra população semi-livre nos arredores de São Paulo, dois grupos do Parque Estadual do Jaraguá (PEJ; Ramos-da-Silva \& Ottoni 2005, Ramos-da-Silva, Resende \& Ottoni 2005).

O PEJ, localizado na região noroeste do município de São Paulo (2327'42" S - 46²45'44" W), tem uma área de 492,68 hectares, sendo 34 dos quais destinados ao centro de turismo. Exibe um relevo montanhoso de serras alongadas, com altitude de $700 \mathrm{~m}$ a $1.135 \mathrm{~m}$, sendo um dos últimos remanescentes de mata atlântica da região metropolitana de São Paulo, e abriga uma fauna bem diversificada, incluindo muitas espécies de mamíferos. É composto de floresta ombrófila densa e floresta estacional semidecidual. Nas proximidades do Pico do Jaraguá, a vegetação predominante são os campos de altitude, com algumas espécies de palmeiras, inclusive jerivás.

O Grupo "Grande" variou de 28 a 30 indivíduos, sendo no final da coleta de dados formado por quatro machos adultos, sete fêmeas adultas, quatro subadultos (machos), treze juvenis e um infante. O Grupo "Pequeno" variou de 5 a 7 indivíduos, sendo ao final da coleta composto por um macho adulto, três fêmeas adultas, um juvenil e dois infantes. Os grupos se encontraram e se misturaram em cinco ocasiões, no início do estudo. Os registros sobre suas origens são escassos: alguns dos macacos (provavelmente 4) eram antigos cativos em exibição pública (soltos, segundo relatos, em 1992), outros já viviam em liberdade na área. A maioria dos indivíduos presentes durante o estudo nasceu no parque.

Os dados foram obtidos a partir de observações indiretas (exame diário dos sítios de quebra) e diretas (método de "Todas as Ocorrências" de episódios de quebra de cocos).

A técnica utilizada pelos macacos consistia basicamente em segurar e golpear com a pedra segura nas duas mãos, como havia sido observado no PET. Os indivíduos subadultos foram responsáveis por quase metade dos 
episódios de quebra de cocos (41.25\%), seguidos dos adultos (31.25\%) e dos juvenis (27.50\%). Entre os adultos, os machos eram mais ativos que as fêmeas, tendo sido responsáveis por $80 \%$ dos episódios de quebra de cocos. Cerca de $25 \%$ dos episódios de uso de ferramentas foram observados por coespecíficos, na maioria juvenis - como de costume, bastante tolerados pelos mais velhos.

De maneira semelhante ao verificado no PET, um levantamento da distância de cada sítio $(\mathrm{N}=71)$ à palmeira mais próxima mostrou que, à medida que aumentava a distância das palmeiras, diminuía o número de sítios.

\subsection{Discussão}

O estudo inicial realizado no PET foi o primeiro a ir além dos relatos anedóticos e fornecer informações sobre a demografia do uso espontâneo de ferramentas pelos macacos-prego em condições naturalísticas.

À época daquele estudo, os juvenis eram os "quebradores" de cocos mais ativos no grupo da Área de Preservação do PET, ainda que não os mais proficientes. Imaginávamos, então, que isso pudesse ser conseqüência de um acesso restrito a itens alimentares mais desejáveis (i.e., mais fáceis de processar) ou porque este recurso, sendo mais disperso, estivesse menos sujeito ao monopólio dos adultos dominantes. Por outro lado, a atividade manipulatória parece bem atraente para os jovens macacos-prego, mesmo não havendo contingência entre manipulação e aquisição de alimento (Visalberghi, 1988; Fragaszy \& Adams-Curtis, 1997). Além disso, os juvenis são geralmente exploradores mais ousados, enquanto os dominantes tendem a se expor menos aos riscos envolvidos na atividade no solo.

A proficiência na quebra de cocos, constatamos, requer anos para ser atingida - e possivelmente nem todos os indivíduos a alcancem plenamente. Os resultados do nosso estudo foram análogos ao observado em chimpanzés (Inoue-Nakamura \& Matsuzawa, 1997), que, embora tendo já adquirido as ações básicas para a quebra de cocos com 2,5 anos de idade, não as combinam numa seqüência apropriada até os 3,5 anos. 
Quando publicamos os primeiros resultados da pesquisa no PET, freqüentemente nos era indagado se o comportamento de quebra de cocos com pedras não seria algo aprendido no cativeiro, com os humanos. Que os macacos-prego eventualmente estivessem imitando um comportamento complexo dos humanos, já seria interessante em si mesmo, mas não parecia ser este o caso, inclusive por que, até onde tivéssemos conhecimento, humanos não consomem cocos de jerivá - certamente, não no PET.

Anderson (1990) havia observado a quebra de frutos encapsulados com pedras por macacos-prego no laboratório mas considerou que isso poderia, em alguma medida, constituir um artefato do cativeiro, algo que não seria de se esperar na natureza, devido ao hábito arbóreo dos macacos-prego. Mas a "arborealidade" é uma questão de grau: em ambientes mais abertos, como o cerrado ou a caatinga (ou mesmo na mata pluvial - Izar, Rímoli, comunicações pessoais), os macacos-prego podem passar consideravelmente mais tempo no chão. Visalberghi, por outro lado, levando em conta tanto as capacidades cognitivas quanto as habilidades motoras dos macacos-prego, previu que esta espécie possivelmente exibiria comportamentos inovadores e uso de ferramentas para a quebra de cocos, se observados em locais com cocos e pedras disponíveis (Visalberghi, 1987). Nossas observações de suas posturas na quebra de cocos - bem como sua destreza ao andar bipedalmente (Silva, Resende \& Ottoni 2000, Falótico \& Ottoni 2007) ao carregar pedras ou outros objetos nas mãos - desde o início sugeriam que os macacos-prego estivessem bastante bem adaptados para atividades no chão.

As observações qualitativas do desencadeamento freqüentemente sincronizado dos surtos de quebra de cocos sugerem um efeito de facilitação social: os indivíduos parecem mais propensos a ir ao solo quebrar cocos quando outros já o estão fazendo (o que produziria um efeito de diluição, diminuindo os riscos individuais de predação).

Langguth \& Alonso (1997) consideram que a quebra de cocos de jerivá poderia constituir o uso de um recurso menos preferido em períodos de escassez alimentar. Uma vez que este certamente não era o caso em nosso estudo no PET, nossa hipótese era a de que a ocorrência deste comportamento dependeria (além da disponibilidade de cocos e pedras) não só da disponibilidade de alimento de mais fácil acesso, mas de um compromisso 
entre esta, o tipo de vegetação (determinando o grau de terrestrialidade) e o risco de predação. Assim, em condições favoráveis, a quebra de cocos poderia acontecer mesmo na presença de outras fontes de alimento.

Os relatos anedóticos como o de Fernandes (1991), e as então recémpublicadas observações indiretas de sítios de quebra em áreas de Cebus libidinosus (Langguth \& Alonso 1997) indicavam que havia muito a ser descoberto na natureza, em especial em ambientes mais abertos, como os de savana.

Enquanto isso, os estudos no PET prosseguiam. Os padrões demográficos que tínhamos observado e a dinâmica social associada à quebra de cocos nos colocavam uma série de novas questões a serem examinadas através de um estudo do desenvolvimento ontogenético da manipulação de objetos e do uso de ferramentas. 


\section{Capítulo 3: O desenvolvimento ontogenético do uso de ferramentas}

Tendo concluído os primeiros estudos descritivos da forma e da demografia da quebra de cocos com o uso de ferramentas pelos macacos do PET, buscamos compreender melhor o seu desenvolvimento ontogenético e as potenciais influências do contexto social sobre a aprendizagem individual.

Matsuzawa (1994) estudou o desenvolvimento do uso de ferramentas similares para os mesmos fins por chimpanzés selvagens, com o auxílio de intervenções experimentais (fornecendo cocos em áreas preparadas para 0 monitoramento). Num estudo longitudinal da ontogenia da quebra de cocos, Inoue-Nakamura e Matsuzawa (1997) verificaram que o comportamento aparece no repertório dos chimpanzés entre os três e os cinco anos de idade, mas se equipara em proficiência ao dos adultos a partir dos nove anos. Estes autores identificaram quatro estágios no desenvolvimento dos chimpanzés, envolvendo (1) a manipulação de objetos isolados (por volta de 1 ano de idade), (2) a manipulação de (pelo menos) dois objetos associados (por volta de 2 anos), (3) a manipulação de conjuntos de objetos associados (por volta de 3 anos) e (4) finalmente, por volta dos 4 anos de idade, a quebra proficiente de cocos com o auxílio de um par de ferramentas, um "martelo" (de pedra em Bossou, mas podendo consistir de um pedaço de madeira em outros locais, como Täi, cf. Boesch \& Boesch 1983) e uma "bigorna" (geralmente, outra pedra).

O desenvolvimento de filhotes de Cebus apella e de Saimiri sciureus, semelhantes na morfologia, do nascimento aos sete meses de idade, foi comparado por Fragaszy, Baer \& Adams-Curtis (1990), que constataram uma dependência mais prolongada dos primeiros, com um desmame mais lento, mais cuidado parental e menor locomoção. Os infantes de macacos-prego 
começavam a manipular objetos mais tarde, mas eram, a partir daí, mais persistentes nesta atividade. Num estudo longitudinal mais prolongado, Fragaszy \& Adams-Curtis (1997) acompanharam os dois primeiros anos de vida de macacos-prego cativos, com especial atenção para o desenvolvimento dos comportamentos manipulatórios, que aumentam em freqüência até os 12 meses e então se estabilizam. Por volta dos 18 meses, época do aparecimento dos primeiros dentes definitivos, os infantes já se movem com mais segurança e exploram mais o ambiente. Quando o desenvolvimento dos dentes e da musculatura da mandíbula possibilita o processamento de alimentos mais duros, entre os 17 e os 30 meses - bem depois do desenvolvimento do repertório motor necessário - eles vão se tornando auto-suficientes no forrageamento.

No caso dos chimpanzés, verificou-se a importância da influência da mãe neste processo de desenvolvimento. Em nosso grupo de macacos-prego, na época do início da pesquisa ${ }^{17}$, a atividade de quebra de cocos era rara ou ausente no repertório da maioria das fêmeas, o que restringia o papel das mães como "modelos" potenciais (elas protagonizaram apenas 8 dos 138 episódios de quebra registrados em Resende 2004), mas a tolerância generalizada para com os infantes, inclusive por parte dos machos adultos, garantia as possibilidades de influências sociais na aprendizagem dos jovens.

\subsection{A ontogênese da quebra de cocos}

A coleta de dados da então doutoranda Briseida D. Resende foi realizada entre março de 2000 e julho de 2002, utilizando os métodos do "Animal Focal" (onde, dados os objetivos do estudo, foram priorizados os indivíduos com menos de três $a_{0}{ }^{18}$ ) e de "Varreduras Focais" (Altmann 1974), além do registro de “Todas as Ocorrências" de quebra de cocos ou similares (Resende 2004).

\footnotetext{
${ }^{17}$ Nos últimos, a participação das fêmeas do grupo da AP do PET na quebra de cocos aumentou (v. Capítulo 4).

${ }^{18}$ Nas observações de Animais Focais (Altmann 1974), os sujeitos escolhidos eram seguidos por 10 minutos, 2-8 vezes/semana (sujeitos abaixo de 3 anos) ou 2 vezes ao mês (acima de 3 anos).
} 
O grupo da Área de Preservação do PET, já bastante habituado, variou, nesse período, de 16 a 26 indivíduos, que foram classificados como infantes (do nascimento até a independência, observada entre os 9 e os 15 meses de idade), juvenis (machos da independência aos 5 anos, fêmeas até a maturidade sexual, calculada retroativamente subtraindo-se 180 dias de gestação do nascimento do primeiro filhote), subadultos (apenas machos entre 5 e sete anos, com tamanho de adulto mas topete pouco desenvolvido) e adultos (fêmeas reprodutivas, com cerca de 5 anos, e machos com mais de sete anos de idade).

Inspirados em Inoue-Nakamura \& Matsuzawa (1997; v acima), definimos quatro níveis de Complexidade Manipulatória: Manipulação Simples (o sujeito manipula um objeto, item alimentar ou substrato), Manipulação Composta Nível 1: o indivíduo manipula objeto (ou item alimentar) em relação a um substrato (exemplo: bater uma pedra contra um tronco), Manipulação Composta Nível 2: o indivíduo manipula associadamente dois objetos ou itens alimentares e Manipulação Composta Nível 3: o indivíduo manipula 2 objetos em relação ao substrato (ex.: golpear com uma pedra ["Martelo"] um coco posicionado sobre outra pedra ["bigorna"]).

Os episódios de quebra foram classificados como de Quebra Proficiente (QP, em que o animal conseguia efetivamente romper cocos e acessar seu endosperma ou larvas de inseto), Quebra Adequada (QA, onde um fruto era posicionado e golpeado adequadamente, mas por algum motivo não houve o rompimento da casca), Quebra Não-Determinada (QN, ode não foi possível verificar se se tratou de QP ou QA) e Quebra Inepta (QI), que envolvia o posicionamento de um objeto inadequado para a quebra, o uso de "martelos" ou "bigornas" inadequados ou o golpear do "martelo" contra a "bigorna" sem que nada tivesse sido posicionado sobre esta para ser quebrado. Note-se que a definição acima é um pouco diferente da empregada em Ottoni \& Mannu (2001), onde "Quebra Inepta" incluía ainda comportamentos que passamos a classificar como "Exploração de Pedras e Cocos", abrangendo todas as formas de manipulação destes objetos de formas diferentes das observadas na quebra de cocos, como jogar pedras para o alto, batê-las uma contra a outra ou golpeá-las contra objetos ou substratos não-funcionais 
enquanto "bigornas". Muitas destas atividades, mesmo quando dirigidas para objetos nos sítios de quebra, pareciam ter antes um caráter lúdico que constituir uma tentativa de quebrar cocos. No entanto, a "brincadeira" com objetos é algo notoriamente difícil de definir operacionalmente (Rasa 1984, Beckoff \& Byers 1998) em criaturas não-verbais (sejam elas macacos ou crianças pequenas); o macaco que bate um coco contra outro no sítio de quebra pode estar apenas apreciando o barulho, mas pode também estar verificando se há larvas de besouro. Assim, nos ativemos ao termo "exploração" como fez Huffman (1984, 1996), no caso da "manipulação de pedras" pelos macacos japoneses, ao substituir o termo "brincadeira" em favor de uma designação mais "neutra".

\subsubsection{A emergência dos níveis de complexidade da manipulação de objetos}

A Manipulação Simples aparece cedo: os infantes agarram objetos com poucas semanas de vida e, em mais algumas semanas, já os batem ou esfregam contra algum substrato (Manipulação Composta Nível 1). Ao se afastarem mais da mãe, no segundo semestre, os infantes começam a explorar os sítios de quebra de cocos e executar Quebras Ineptas.

A exploração de pedras e cocos nos sítios ocorria, tipicamente, em períodos de descanso do grupo, muitas vezes após comerem o alimento aprovisionado (de maneira bastante semelhante ao que acontece com a manipulação de pedrinhas pelos macacos japoneses, cuja finalidade permanece obscura; Nahallage \& Huffman 2007); neste contexto foram observados os raros eventos de Manipulação Composta Nível 2, registrados quando os irmãos juvenis Químico e Manuel tinham cerca de três anos de idade. Químico bateu cocos contra cocos durante episódios de quebra, mas o mais curioso comportamento observado dentre os poucos que se enquadravam na definição foi o de tomar duas pedras pequenas, uma em cada mão, e batêlas uma contra a outra repetidamente. Esse comportamento foi observado em julho de 2001, sendo exibido por Manuel (que morreu poucos meses depois) e, subseqüentemente, por três outros indivíduos (a fêmea adulta Janete, sua provável filha - a juvenil Vavá, e Químico). 
A Manipulação Composta Nível 3 começa a aparecer antes de um ano de idade e vai se tornando mais comum com o aumento da freqüência da Quebra Inepta, que se intensifica no quarto semestre. No entanto, apenas no segundo ano de idade os infantes (em transição para juvenis) se mostraram capazes de manipular coordenadamente três itens (2 objetos soltos em relação ao substrato) - e o posicionamento adequado de um coco sobre a "bigorna" só foi observado a partir dos 20 meses de idade. Nesta fase, estes indivíduos passavam a ficar mais próximos dos juvenis mais velhos e dos machos adultos.

Conforme anteriormente observado, os infantes são muito menos ativos na quebra de cocos (total de episódios QP+QA+QN+QI) que juvenis e adultos/subadultos, que superam os juvenis se excluídos os episódios de Quebra Inepta. Joana e Darwin executaram Quebras Adequadas antes dos 2 anos de idade ${ }^{19}$ - mas Joana, que batia pedras contra pedras nos sítios desde os 6 meses e exibiu Quebras Adequadas aos 22 meses de idade, morreu antes de completar 2 anos. Manuel, por outro lado, só foi visto manipulando pedras nos sítios com 159 semanas e nunca tentou quebrar cocos (apesar de ser um freqüente observador de quebras e "scrounger") até falecer, com 3 anos e 5 meses. Os indivíduos acompanhados por Resende desde o nascimento (Filó, Fractal, Ada e Janeiro) só executaram Quebras Ineptas até o final da coleta de dados.

A emergência da Quebra Proficiente pôde ser acompanhada, durante este estudo, em dois machos juvenis, Darwin e Químico, respectivamente com 24 e 29 meses de idade (o que não difere muito do observado anteriormente por $\mathrm{M}$. Mannu com relação a Frank), uma fase de intensa atividade exploratória.

Há uma longa trajetória de exploração individual de objetos particularmente pedras - durante a qual os padrões de manipulação se complexificam gradualmente, da manipulação de objetos isolados, nos primeiros meses de vida, até o uso integrado de dois objetos mais o substrato, necessário para a quebra de cocos. E embora o processo básico de aprendizagem do uso de ferramentas na quebra de cocos se dê nos primeiros anos de vida, alguns dos animais mais velhos, embora em geral dedicando

\footnotetext{
19 Mas pode haver casos "precoces" como o de Cisca, que tentou quebrar um coco (adequadamente) com apenas 39 semanas de idade (Mannu 2002) .
} 
menos tempo a esta atividade, se mostram bem mais proficientes que juvenis ou subadultos, quebrando às vezes vários cocos em um único episódio - e em um breve intervalo de tempo, mostrando que há ainda espaço para o aperfeiçoamento da técnica individual ao longo da vida adulta.

\subsection{Influências sociais na aprendizagem}

Em ambientes muito pouco variáveis, depender de aprendizagem pode ser uma estratégia pouco adaptativa, se predisposições comportamentais "inatas" puderem dar conta do repertório necessário para a sobrevivência. Já em ambientes menos previsíveis, os benefícios de um sistema mais plástico e "aberto" sobrepujarão os custos. Se a variabilidade ambiental for muito grande, serão melhor sucedidos os organismos capazes de aprender por si sós com base na interação direta com cada problema. Mas em casos de variabilidade "intermediária" no ambiente, em que determinadas condições se mantenham constantes por algum tempo, será provavelmente vantajoso aproveitar algo da experiência dos outros indivíduos, através de aprendizagem socialmente mediada.

Se estes períodos de relativa estabilidade forem superiores aos intervalos entre gerações, podemos esperar alguma transmissão "vertical", dos mais velhos para os mais novos; se a estabilidade se restringir a um prazo mais curto, aumenta a probabilidade de transmissão "horizontal" (entre coetâneos) (Laland \& Kendall 2003).

Aproveitar-se da experiência alheia pode constituir uma estratégia altamente eficiente para contornar a necessidade de se repetir individualmente a descoberta por tentativa-e-erro de cada novo comportamento; o grau em que a aprendizagem socialmente mediada efetivamente ocorre ou os mecanismos cognitivos envolvidos neste processo em cada sociedade animal, no entanto, constituem questões bastante polêmicas ( $v$. discussões recentes sobre a difusão da lavagem de batatas e trigo entre macacos japoneses; v. Capítulo 7). A terminologia usada na categorização destes fenômenos também continua longe de uma efetiva padronização, o que complica o debate (Heyes 1993). 


\subsubsection{Conceitos e definições}

Visalberghi \& Fragaszy (1990a) subdividiram a "aprendizagem social" em três instâncias básicas: facilitação social, realce de estímulo (stimulus enhancement) e imitação. Por facilitação social designaram o aumento na probabilidade da emissão de um comportamento (já presente no repertório do indivíduo) diante da presença de outros indivíduos exibindo o mesmo comportamento. A facilitação aumentaria a homogeneidade comportamental ao aumentar a homogeneidade motivacional, e não por influenciar o desempenho de atos motores específicos (um exemplo estaria no mobbing contra predadores).

O termo realce de estímulo (ou "realce de local" ["local enhancement"] Thorpe 1956, apud Tomasello 1990) se refere aos processos em que a atenção de um indivíduo é atraída para determinados elementos do ambiente em função da atividade de outros indivíduos, o que aumenta a probabilidade de interação do observador com o estímulo ambiental em questão. Whiten \& Ham (1992) fazem uma distinção entre o "enhancement" e o condicionamento observacional: enquanto que no primeiro o observador aprende uma orientação particular em relação a determinado elemento do ambiente, no segundo o observador aprende algo a respeito do significado do estímulo ao associar uma resposta incondicionada a um estímulo novo.

Galef (1988) reúne a facilitação e o "enhancement" sob o rótulo de "social enhancement", e Heyes (1993) divide a aprendizagem social em "nãoimitativa" (aprendizagem sobre eventos ou estímulos do ambiente) e "imitativa" (aprendizagem de respostas comportamentais).

A imitação é o termo mais problemático desta classificação, tendo sido utilizado com diferentes sentidos por diferentes autores ${ }^{20}$. No sentido mais restrito, designa apenas as situações em que um comportamento novo no repertório de um animal é copiado a partir da observação do comportamento de um outro indivíduo. Tal definição dificulta a caracterização de casos de imitação

\footnotetext{
${ }^{20} \mathrm{Na}$ literatura sobre aprendizagem do canto em aves, a imitação é um fenômeno melhor demonstrado e um conceito pouco questionado, talvez, para alguns (Whiten \& Ham 1992), porque a imitação vocal seja mais fácil que a visual - uma noção posta em cheque por Slater (2003).
} 
em estudos naturalísticos, uma vez que exige que se conheça em detalhe a história ontogenética de cada indivíduo.

Byrne \& Russon (1998) se referem a duas modalidades bastante distintas de "imitação", a "imitação ao nível de programa" (program-level imitation), que envolve a cópia da estrutura do comportamento, com suas seqüências, aninhamentos hierárquicos de "sub-rotinas" e pontos de "verificação" - o que supõe um entendimento das finalidades e mecanismos causais subjacentes à atividade imitada - e a "imitação ao nível da ação" (action-level imitation), que consiste na pura cópia motora e, que seria, portanto, mais importante para processos de assimilação de gestos comunicativos ou ritos sociais que para a aprendizagem de técnicas manipulativas complexas.

A aprendizagem por imitação é um componente tão fundamental na transmissão social de informações na espécie humana que pode sobrepujar a exploração de possibilidades diferentes mesmo em situações em que esta última estratégia se mostra mais vantajosa. Não parece ser assim entre os primatas não-humanos. Numa situação experimental (Horner \& Whiten 2005), crianças e jovens chimpanzés foram expostos a um modelo humano obtendo comida de uma caixa-problema, usando uma combinação de procedimentos relevantes e irrelevantes, em duas situações: com a caixa-problema opaca ou transparente. A caixa transparente deixava visível que um dos movimentos (introdução de um bastão em um furo na tampa) era irrelevante para a obtenção da comida. Com a caixa opaca, crianças e chimpanzés copiaram toda a seqüência do modelo; com a caixa transparente, os chimpanzés rapidamente deixaram de reproduzir a parte irrelevante da manipulação, mas as crianças permaneceram copiando fielmente o procedimento observado.

Uma processo mais "restrito" que a imitação seria a emulação. O termo se refere à cópia de uma parte muito especial do comportamento do modelo: a culminação de uma seqüência dirigida para uma finalidade, o resultado final do comportamento. Tomasello e colaboradores (1987, apud Whiten \& Ham 1992) verificaram que chimpanzés juvenis que tinham assistido a modelos utilizando varetas para alcançar objetos inacessíveis foram mais rápidos em utilizar as mesmas ferramentas na solução do problema do que os animais do grupo controle (sem modelo) - mas cada indivíduo "inventava" sua própria forma de 
utilizar as varetas, ao invés de reproduzir a topografia específica do comportamento observado.

Cabe ainda mencionar o ensino, a mais sofisticada das modalidades de transmissão social de informação por implicar, em seu sentido mais estrito, em uma iniciativa "deliberada" do "instrutor", baseada na atribuição de estados cognitivos a outros indivíduos (ausência de conhecimento a ser modificada), o que corresponde à posse de uma "Teoria da Mente" (Theory of Mind, ToM). Embora a "ToM" tenha se tornado um conceito fundamental para o estudo do desenvolvimento cognitivo em humanos (Ottoni 2009), não há evidências desta capacidade em outras espécies. Para Premack, que forjou o termo (Premack \& Woodruff 1978), seus chimpanzés "aculturados" exibiriam, quando muito, uma forma muito limitada de "ToM" (Premack 1988). A literatura recente inclui alguns títulos que se referem a "ensino" em animais não-humanos, mas empregando o termo de modo bastante impreciso (e ignorando em boa parte a literatura especializada na discussão destes conceitos), para cobrir fenômenos que seriam melhor caracterizados como de "scaffolding" - a criação de condições facilitadoras da aprendizagem, como Terkel (1996) observou na transmissão social da técnica de descascar pinhas por ratazanas - ou outras formas de "canalização" social da aprendizagem. Nesta modalidade de relatos com um uso "frouxo" do conceito de "ensino", há de suricatas (Thornton \& McAuliffe 2006) a formigas (Franks \& Richardson 2006).

No caso dos chimpanzés, há dois relatos sobre casos de "ensino", stricto sensu: um em circunstâncias muito particulares de "enculturamento" (crossfostering), envolvendo a aprendizagem da linguagem de sinais de surdosmudos (ASL) por Loulis, filhote adotado por Washoe, no seio de um grupo cativo treinado no uso (inclusive intra-grupal) desta forma de comunicação (Fouts, Fouts \& Van Cantfort 1989). O outro caso se refere a uma observação de campo (chimpanzés selvagens de Täi, Costa do Marfim) de uma mãe corrigindo a posição com que seu filhote segurava um "martelo" de madeira ao tentar quebrar cocos (Boesch 1991). De modo geral a transmissão social de informação nos primatas não-humanos parece depender mais do interesse dos 
jovens nas atividades dos adultos (King $1994^{21}$ ) do que em quaisquer disposições destes para o ensino deliberado.

Mais recentemente, Fragaszy \& Visalberghi (2001) deram preferência ao uso do termo "aprendizagem socialmente enviesada (socially biased learning) ${ }^{22}$ para evitar a falsa dicotomia entre uma "aprendizagem individual" e uma "aprendizagem social", já que toda a aprendizagem é, sempre, individual ("social" é o contexto "facilitador" ou "canalizador").

\subsubsection{Influências sociais na aprendizagem: estudos em cativeiro}

Fragaszy \& Visalberghi (1989) estudaram em macacos-prego processos de aprendizagem da solução de problemas envolvendo a manipulação de ferramentas: os indivíduos aprendiam prontamente a relação entre a ferramenta e a comida, mas não imitavam o comportamento manipulatório do modelo. Estas autoras (Visalberghi \& Fragaszy 1990b) induziram experimentalmente a disseminação do comportamento de lavagem de comida em um grupo de macacos-prego e outro de Macaca fascicularis (crabeating ou long-tailed macaques): só alguns indivíduos aprenderam a lavar o alimento sujo de areia e não se observaram evidências de imitação; algumas situações de "scrounging" (tomar o alimento lavado por outro) foram registradas. Processos sociais parecem afetar o aparecimento de comportamentos inovadores de maneiras opostas, havendo "social enhancement", por um lado, e, por outro, efeitos sociais inibidores (Fragaszy \& Visalberghi 1990), como restrições no acesso ao aparato por parte de animais mais dominantes e o "roubo" de ferramentas por outros. Efeitos inibidores ou disruptivos da presença de adultos sobre a atividade exploratória dos juvenis, como assinalamos anteriormente, foram também registrados por Perondi, Izar \& Ottoni (1995).

A fim de examinar a influência da atividade exploratória dos indivíduos

\footnotetext{
${ }^{21}$ O conceito de "transmissão social de informação" (King 1991, 1994) não discute os mecanismos cognitivos individuais subjacentes - sua definição envolve apenas o aumento na homogeneidade comportamental entre os indivíduos em conseqüência da interação social e a persistência desta homogeneidade no tempo.

${ }^{22}$ A propósito, tenho feito uso indiscriminado dos termos "aprendizagem socialmente mediada" (usado por muitos e que me soa melhor) e "aprendizagem socialmente enviesada" (tradução mais fiel de Fragaszy \& Visalberghi 2001, mas que soa melhor em inglês). Talvez "canalizada" ou "direcionada" sejam alternativas interessantes.
} 
mais velhos sobre a dos mais novos (em duas tarefas, uma de quebra de nozes, outra de obtenção de iogurte por meio de palitos), mas evitando que os mais velhos impedissem o acesso dos jovens ao mesmo, Fragaszy, Vitale \& Ritchie (1994) construíram uma situação onde dois aparatos iguais eram oferecidos, um na área central do cativeiro e outro em uma área protegida, à qual apenas infantes e juvenis tinham acesso. Verificou-se que a atividade dos juvenis era pouco coordenada com a dos adultos - e quando havia sinais de coordenação, isto se dava entre os juvenis mais jovens - mas apenas juvenis mais velhos solucionaram adequadamente a tarefa.

A influência de modelos experientes na abertura seqüencial dos vários fechos de uma tampa para obter uma passa (Adams-Curtis \& Fragaszy 1995) pareceu se restringir a um efeito de "local enhancement" - e apenas sobre os juvenis (mais tolerados socialmente, mais coesos como grupo etário e, aparentemente, mais curiosos). Em se tratando de uma tarefa envolvendo uma seqüência de operações (abertura de fechos), foi possível comparar o desempenho dos "manipuladores", não tendo sido constatado qualquer aumento gradual na correspondência (matching) entre o comportamento de "modelos" e "observadores", o que seria um indicador de imitação.

A abertura de uma caixa fechada por três trincos foi a tarefa a que submetemos macacos-prego de dois grupos cativos em parques zoológicos, pare investigar possíveis efeitos de aprendizagem observacional (Resende \& Ottoni 2001). Um sujeito em cada grupo, de ranking hierárquico intermediário, foi treinado utilizando-se uma configuração do aparato que tornava necessária uma determinada seqüência na abertura dos três trincos (Figura 20). Estes sujeitos serviram de "modelos" para os "observadores" - os outros membros de seus respectivos grupos (que aprenderam previamente a abrir a caixa com um só trinco fechado). Ao final da "demonstração", o modelo era removido e era oferecida ao "observador" a oportunidade de interagir com o aparato - que se encontrava, agora, numa configuração que permitia que a caixa fosse aberta destrancando-se os 3 trincos em qualquer ordem. Apenas dois dentre os seis "observadores" testados efetivamente olharam para a atividade dos "modelos" - e apenas estes conseguiram abrir a caixa no teste - mas sem reproduzir a seqüência demonstrada, o que sugere um efeito de "enhancement" (e 
eventualmente, "emulação"), mas ausência de "imitação".

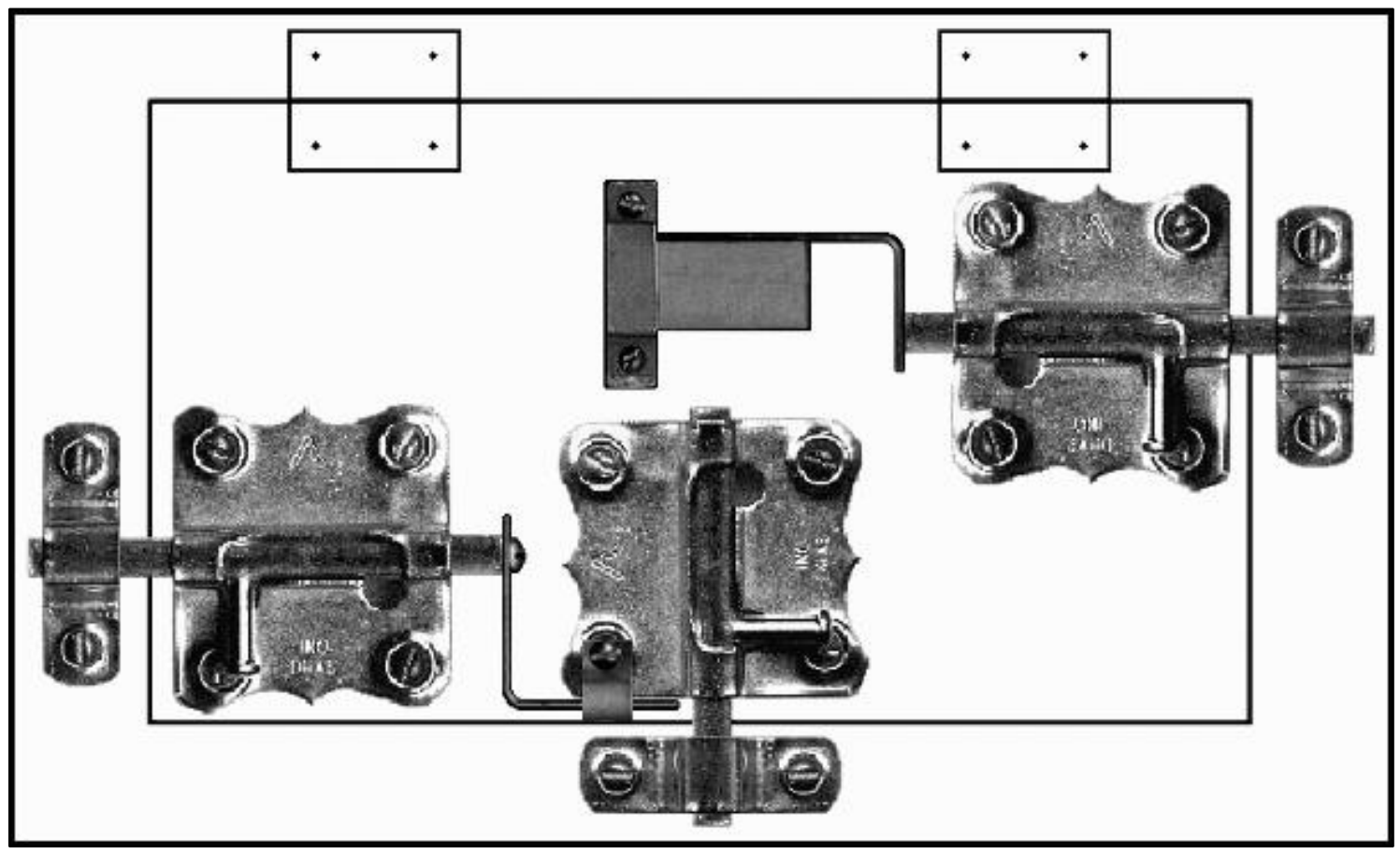

Figura 20. Tampa da caixa-problema utilizada em Resende \& Ottoni (2001) na condição de 3 trincos dependentes (que tinham de ser abertos numa determinada ordem, da direita para a esquerda).

A metodologia deste experimento se inspirou na de Galef, Manzing \& Field (1986), que por sua vez constituiu uma versão aperfeiçoada do estudo de Dawson \& Foss (1965) com periquitos. Este paradigma foi empregado no estudo da aprendizagem socialmente mediada (observacional) em outras espécies, tais como ratos (Heyes \& Dawson 1990; Heyes, Dawson \& Nokes 1992), sagüis (Bugnyar \& Huber 1997), orangotangos (Call \& Tomasello 1995), chimpanzés e crianças (Tomasello, Savage-Rumbaugh \& Kruger 1993; Whiten et al 1996) e macacos-prego (Custance, Whiten \& Fredman 1999). Neste último caso, os macacos observaram modelos humanos abrirem uma "fruta artificial" (caixa-problema) com 2 técnicas possíveis de abertura. Sua manipulação subseqüente do aparato, para os autores, indicou mais que apenas "enhancement" (o que eles chamaram de "object movement reenactment", e, talvez uma forma simples de imitação, a "personificação" [impersonation]).

Adams-Curtis \& Fragaszy (1995) treinaram um macaco-prego em um grupo cativo a abrir uma caixa-problema através de ações seqüenciais e permitiram que o grupo o observasse, quando este se tornou proficiente. Um 
dos observadores passou a interagir mais com o aparato após observar o manipulador, mas - como no nosso caso - sem imitar a seqüência observada.

A variabilidade individual observada na forma de manipulação dos palitos no experimento de extração de melado (Perondi, Izar \& Ottoni 1995) favorece a idéia de que embora os sujeitos talvez possam aprender por observação a relação entre o uso da ferramenta e a obtenção do recurso (emulação), os "detalhes" motores do procedimento resultariam, em grande parte, de processos individuais de tentativa-e-erro (pudemos observar diferentes gestos idiossincráticos no uso dos palitos por cada um dos sujeitos manipuladores) - um mecanismo que, embora mais "modesto" que a imitação em termos cognitivos, pode se mostrar extremamente funcional e adaptativo em espécies com grande propensão à manipulação exploratória.

\subsubsection{Observação da quebra de cocos por coespecíficos em semi- liberdade}

No grupo da Área de Preservação do PET, mesmo infantes mais novos manipulam objetos (pedras inclusive) e os batem contra o substrato, e indivíduos de um ano de idade freqüentemente tentam quebrar cocos. Entretanto, a coordenação dos movimentos e o posicionamento adequado de cocos, "martelos" e "bigornas" não costumam ser atingidos até o terceiro ano de vida (Resende et al 2008).

Desde cedo, no entanto, como já havíamos nos dado conta nos estudo inicial, infantes e juvenis acompanham com grande interesse a atividade manipulatória de outros indivíduos. Mais de um quarto (26.6\%) dos episódios de quebra de cocos registrados no estudo de Resende (2004) foram observados por coespecíficos. Os juvenis se mostraram os observadores (significativamente) mais ativos, e os infantes eram significativamente menos observados por outros coespecíficos. Como entre os chimpanzés (Biro et al 2003), os observadores coespecíficos costumam ser mais novos que os "quebradores" observados, mas o papel das mães como modelos foi bem menos destacado, seja porque as fêmeas do grupo de macacos-prego do PET fossem (na ocasião), em média, menos ativas na quebra, seja porque que os infantes e juvenis podiam observar outros juvenis ou machos adultos. Os 
machos - em especial, o macho dominante - eram proporcionalmente mais observados que as fêmeas, e a atividade mais observada era a manipulação de alimento (as atividades dos machos dominantes relacionadas à alimentação tendem a despertar muito interesse; Sestini \& Ottoni 1999).

\subsubsection{Scrounging e observação}

Os observadores dos episódios de quebra de cocos, em geral mais jovens e menos proficientes, são bem tolerados pelos "quebradores", inclusive ao comer parte do endosperma de cocos quebrados pelos "alvos" de observação ainda na presença destes (Figura 21).

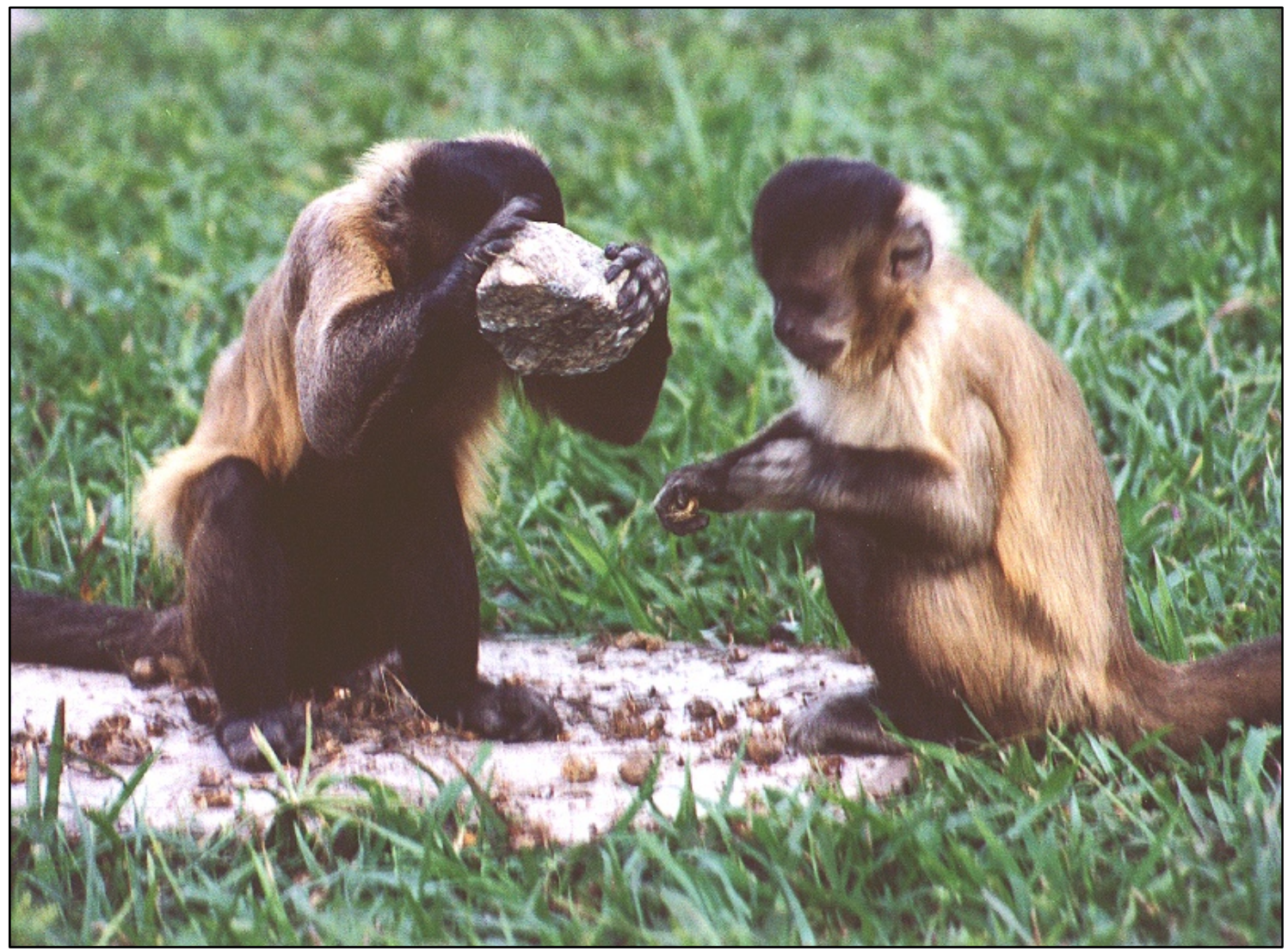

Figura 21. Eli (manipulador) e Edu, observador e scrounger (foto Humberto Conzo Junior).

A motivação "proximal" de comer endosperma, acreditamos, associada à tolerância dos "quebradores" ao "scrounging" imediato dos infantes e juvenis, otimiza as possibilidades da aprendizagem observacional das técnicas (comportamentos) de quebra de cocos.

Estudos mais antigos em laboratório sugeriram que em certos casos o 
"scrounging" imediato inibia ou impedia os indivíduos de aprender as técnicas dos indivíduos proficientes (Fragaszy \& Visalberghi 1984, Giraldeau \& Lefebrve 1987, Beauchamp \& Kacelnik 1991), mas o oposto foi verificado em estudos mais recentes com sagüis (Caldwell \& Whiten 2002) e com orangotangos (Russon 2003). Estes novos resultados sugerem que as correlações entre "scrounging" e aprendizagem variarão em função de diversos fatores, tais como a natureza da interação entre produtores e "scroungers", os distratores potenciais da situação e os custos e benefícios relativos da produção e do "scrounging".

Mas a permanência dos sítios de quebra - configurações ideais dos materiais necessários para a quebra de cocos - cria, por si só, uma situação típica de "estruturação" (scaffolding) da aprendizagem individual. E se a simples possibilidade de manipular as pedras e cocos deixados nos sítios, que se mostra tão atraente para os jovens macacos-prego ${ }^{23}$, já seria suficiente para "canalizar" suas tendências manipulativas, promovendo ao menos uma associação inicial entre os objetos necessários, o "scrounging" ainda que "mediato" ("delayed scrounging", o consumo de restos de endosperma em um sítio após a partida do "quebrador") acrescenta, além de informações sobre o conteúdo de cocos (que de outra forma talvez não se distinguissem de pedrinhas), um mecanismo de "reforçamento positivo" da visitação aos sítios de quebra.

O ambiente alterado pelos "quebradores" de cocos modifica as experiências dos imaturos, "canalizando" suas atividades exploratórias e manipulatórias. Na medida em que estas alterações otimizam as condições para a aprendizagem, modificam as pressões seletivas atuando sobre estes indivíduos, "agregando" valor adaptativo a características associadas a capacidades motoras e cognitivas mais sofisticadas e constituindo, assim, um caso de "construção de nicho" (niche construction, Odling-Smee 1996, Laland, Odling-Smee \& Feldman 2000).

A hipótese de que o endosperma consumido no "scrounging" seja um

\footnotetext{
${ }^{23}$ O efeito de "enhancement" na exploração de larvas no bambu, observado por Gunst, Boinski \& Fragaszy (2008) entre Cebus apella selvagens do Suriname, é particularmente interessante, uma vez que os juvenis exploram mais os caules já abertos pelos mais velhos, embora as chances de encontrar uma nova larva no mesmo bambu sejam praticamente nulas.
} 
reforçador da atividade de visitar e explorar os sítios coloca ainda a possibilidade de os observadores sejam sensíveis ao retorno diferencial resultante de se observar "quebradores" mais ou menos proficientes (observar a Quebra Inepta de um infante não seria tão "reforçador"), uma questão que examinamos a seguir (Capítulo 4)

\subsection{Períodos críticos para a aprendizagem?}

Um jovem macaco-prego, sendo bastante tolerado pelos indivíduos mais velhos, tem amplas oportunidades de observar de perto o uso de ferramentas na quebra de cocos, o que garante as condições ideais para a aprendizagem socialmente enviesada e para a manutenção da quebra de cocos como uma tradição social (v. adiante).

As influências sociais parecem ser importantes, mas não são condição suficiente para a aprendizagem do uso de ferramentas, como atesta o caso de Manuel, o único indivíduo com mais de 2 anos que não quebrava cocos (até falecer, com 3.4 anos de idade), apesar de, já na 29ª semana de vida, ter sido visto manipulando pedras. Sendo um observador extremamente tolerado, Manuel tornou-se um "scrounger" constante de outros indivíduos (Ottoni, Resende \& Mannu 2002).

Mas o que acontece se o indivíduo não crescer numa população onde esta prática esteja presente? É possível aprender a quebrar cocos com ferramentas na maturidade?

Períodos "críticos" ou "sensíveis" para a aprendizagem são bastante familiares aos etólogos - o "imprinting" das aves precoces constituindo o exemplo clássico. A aprendizagem do canto nas aves envolve em muitos casos estas "janelas temporais". Algumas espécies podem ser "aprendizes abertos", como os canários (Serinus canarius), capazes de aprender novas canções ao longo de toda a vida. Outras passam por um período limitado de tempo após o qual suas canções se "cristalizam". Em alguns casos, as fases sensorial (de exposição ao tutor) e sensorial-motora (de prática individual) se superpõem, como nos mandarins (Taeniopygia guttata, "zebra finches"); em outros, elas estão separadas no tempo: um jovem pardal-de-coroa-branca (Zonotrichia 
leucophrys) deixa de sensível à exposição ao canto do tutor antes de começar a vocalizar (Brainard \& Doupe 2002; Slater 2003).

Outro "período sensível" bastante familiar está no desenvolvimento da fala humana: depois do início da adolescência, é difícil aprender a produzir os sons de uma nova língua com a competência de um falante nativo (Doupe \& Kuhl 1999).

Mas se às vezes os chamados "períodos críticos" correspondem a "janelas" temporais bem definidas, associadas a mudanças neurais irreversíveis, em outras se referem apenas a um declínio gradual na prontidão para aprender - que pode se dever a uma série de causas, fisiológicas, cognitivas ou sociais.

No caso dos chimpanzés, Matsuzawa e colaboradores observaram na população de Bossou três casos de fêmeas que não quebravam cocos: duas supostas imigrantes vindas de populações sem esta tradição e uma jovem fêmea nativa. Yunro, embora fosse filha de Yo, uma proficiente quebradora de cocos, havia passado por um período de incapacitação, durante o qual não podia manipular objetos (por causa de uma armadilha de arame que prendeu seu tornozelo esquerdo por volta dos 4 anos de idade e foi retirada apenas meses depois). Matsuzawa (1994) considerou este caso uma possível evidência de um período crítico para a aprendizagem do uso de ferramentas.

E quanto aos macacos-prego? No grupo em estudo no PET, após um longo período sem "recém-chegados", dois machos subadultos se juntaram ao grupo. "X" escapou de uma das ilhas do parque (aonde os animais recentemente confiscados são geralmente soltos) em setembro de 2003. As origens de "Z" são um pouco mais obscuras: ou ele veio também de uma das ilhas, ou foi sub-repticiamente solto na Área de Preservação por um visitante, em fevereiro de 2004.

Nenhum dos dois quebrava cocos, como faria, numa população de "quebradores", qualquer macho com mais de 2 anos de idade.

Ambos podiam observar episódios de quebra, ainda que mais de longe $(5+m)$ do que um infante ou juvenil bem-tolerado, e tinham oportunidade de realizar algum "scrounging" mediato, bem como de explorar e manipular os "martelos" deixados nos sítios, mas Z parecia bem mais interessado nesta 
última atividade que X e, já em 2004, exibia padrões de "Quebra Inepta" comparáveis aos dos infantes mais velhos ou juvenis mais jovens, batendo pedras contra o substrato sem posicionar cocos sob os "martelos", depois comendo restos que já se encontravam espalhados pelo local (num padrão comportamental quase "supersticioso", indicando uma razoável falta de compreensão causal do processo).

Infelizmente, vem a seguir uma "janela" de um ano em nossos dados, de janeiro de 2005 a fevereiro de 2006.

Após este intervalo, constatamos que $X$ havia se tornado um "scrounger" sistemático de sítios de quebra, mas não exibia muitos episódios de manipulação de objetos, muito menos tentativas de quebra de cocos - sequer "Ineptas". No seu caso, ao menos, o "stimulus enhancement" não foi suficiente para promover a aprendizagem do uso de ferramentas.

Z, por outro lado, se tornou um "quebrador" proficiente, comparável à maioria dos juvenis mais velhos (Figura 22).

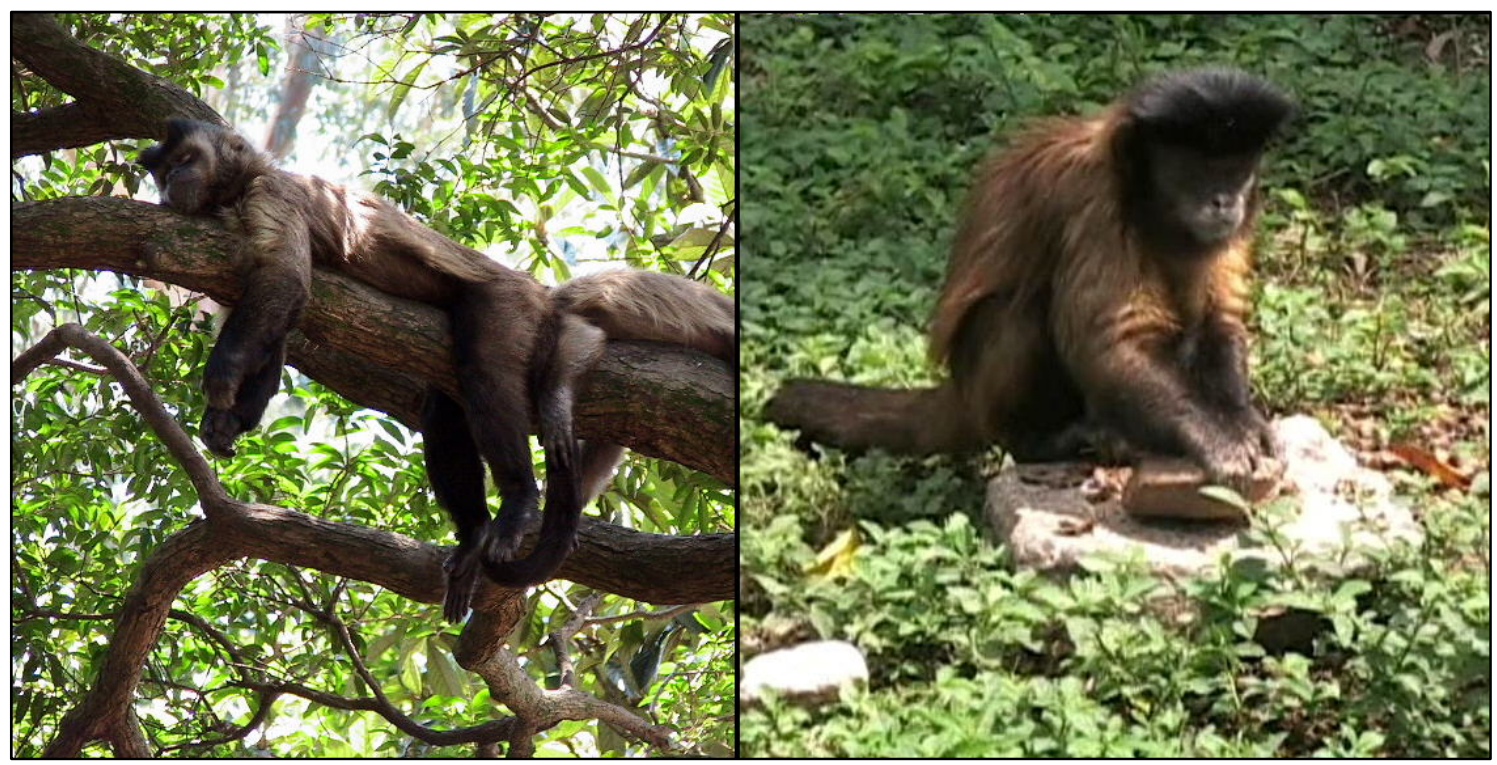

Figura 22. X (foto Tiago Falótico) e Z (foto Camila G. Coelho).

O caso de $Z$ mostra que, a rigor, não há um "período crítico" para a aprendizagem da quebra de cocos com ferramentas, embora as diferenças individuais provavelmente sejam grandes na prontidão para o aprendizado tardio. Os maiores impedimentos parecem estar na esfera social, uma vez que, como assinalamos anteriormente, machos adultos ou subadultos são bem 
menos tolerados por outros machos adultos, por um lado, e tendem, por outro, a deslocar dos sítios de quebra os juvenis proficientes, o que cria algumas barreiras à aprendizagem observacional.

Para Z, ao menos, alguma observação, ainda que à distância, associada a uma intensa manipulação das ferramentas, similar a de indivíduos mais jovens crescendo num grupo de "quebradores", foram suficientes para promover a aprendizagem tardia. E entre 2006 e 2007, Z estabeleceu um relacionamento próximo com a fêmea Janete, quase periférica e altamente proficiente na quebra de cocos, o que seguramente criou oportunidades para observar mais de perto do uso de ferramentas (embora ele já fosse um "quebrador" proficiente no início de 2006).

Como não sabemos nada sobre as experiências pregressas destes dois imigrantes, não podemos, entretanto, descartar a existência de um "período crítico" observacional precedendo a aprendizagem "sensorial-motora" (análogo à fase sensível de "aprendizagem sensorial" no canto dos pardais), nem de um efeito das oportunidades precoces de manipulação de objetos em geral (com uma aprendizagem sensorial-motora prévia em outros contextos de manipulação de objetos facilitando processos posteriores de aprendizagem sensorial-motora em contextos diferentes), mas a trajetória de aprendizagem de Z, que percorreu já adulto uma seqüência de desenvolvimento da técnica de quebrar cocos similar à de um juvenil típico, mostra que a aprendizagem tardia é possível e que não há um "período crítico" no sentido estrito do termo (Ottoni et al 2009).

\subsection{Scrounging e evolução da tolerância social}

No caso do grupo da Área de Preservação do PET, fartamente provisionado, o consumo de cocos de jerivá seguramente não constitui um comportamento decisivo para a sobrevivência, persistindo, talvez, por um misto de motivações "atávicas", "excesso" de tempo livre, elevada terrestrialidade e, quem sabe, algum papel como display sexual (Boinski 2004).

Nesta ocasião, porém, já se começavam a se acumular evidências de 
que o uso de ferramentas na quebra de frutos encapsulados, longe de ser uma idiossincrasia de certos grupos de macacos-prego em parques urbanos, é bastante comum em populações selvagens de ambientes em que a obtenção de alimento de fácil consumo, ao menos nas épocas de seca, pode ser bem mais difícil.

Se os frutos encapsulados constituem um recurso estratégico sazonal, que permite a ocupação de ambientes de savana (caatinga, cerrado), então a tolerância ao "scrounging" por indivíduos imaturos, que não podem extrair este alimento por si sós (seja por falta de técnica ou de força) torna-se uma necessidade (um "fator limitante" decorrente da história de vida da espécie freqüentemente ignorado ao se discutir a importância dos alimentos "alternativos" [fallback foods]). Sendo assim, quaisquer mudanças na dinâmica social produzindo sociedades mais tolerantes teriam tido um grande valor adaptativo, mesmo antes do advento das formas de forrageamento extrativo que envolvem o uso de ferramentas. 


\section{Capítulo 4: Socialidade e uso de ferramentas: brincadeira, "scrounging" e observação inter-individual}

A evidente importância da tolerância social para o "scrounging" e para a observação da manipulação de ferramentas nos levou a investigar mais de perto as relações entre a dinâmica social do grupo, em seu conjunto, e a observação do comportamento dos coespecíficos. Esperávamos, inicialmente, encontrar correlações significativas entre a observação da atividade de outros indivíduos (inclusive do uso de ferramentas) e indicadores gerais de afinidades sociais, tais como a proximidade típica entre as díades de indivíduos.

Por outro lado, verificamos que, a partir do segundo ano de idade, as tentativas de quebrar cocos exibidas por juvenis e infantes eram freqüentemente intercaladas com surtos de brincadeira social (Resende \& Ottoni 2002), o que nos levou a examinar a hipótese de que a observação da quebra de cocos fosse uma conseqüência passiva de afinidades sociais e espaçamento individual (os macacos apenas observariam as atividades de seus parceiros habituais) ${ }^{24}$.

Embora, como assinalamos acima, "brincadeira" seja um conceito difícil de definir, a "brincadeira social" é um pouco menos problemática, ao menos em termos operacionais - e corresponde a algo que não pode ser ignorado, dada a sua aparente importância no desenvolvimento dos primatas imaturos, que são "brincadores" freqüentes (Walters 1987). A brincadeira pode, em muitos casos, ser útil como "treino" para comportamentos adaptativamente relevantes, e a brincadeira social pode ter um papel na construção e manutenção das estruturas sociais (Fagen 1981). Em termos descritivos, trata-se de um

\footnotetext{
${ }^{24}$ Além disso, a brincadeira social, facilitando construção de vínculos, ajudaria a aumentar a tolerância espacial.
} 
comportamento não-agonístico que incorpora vários componentes do repertório dos adultos, inclusive os usados na agressão - mas sem as conseqüências imediatas - de forma repetitiva e exagerada, freqüentemente acompanhado de sinais comunicativos indicadores do contexto, como expressões faciais ou vocalizações "de brincadeira".

Em um estudo-piloto sobre comportamentos de brincadeira com o grupo da Área de Preservação do PET, registramos a atividade dos infantes (7 indivíduos) através de observações focais (10') e registros ad libitum da duração dos episódios de brincadeira e a freqüência de eventos de manipulação exploratória de objetos. Em 570 minutos de observação, os infantes passaram 10.79 minutos brincando (1.89\%), dos quais $90.6 \%$ envolveram Brincadeira Social e 9.4\%, Brincadeira Locomotora. Houve 14 episódios de exploração de objetos, sendo 35.7\% com pedras. No total, os machos brincaram mais do que as fêmeas, mas dois deles foram responsáveis por $95.3 \%$ do tempo de brincadeira social (e os valores para os outros dois foram semelhantes aos das fêmeas). Encontramos uma preferência por companheiros de brincadeira da mesma faixa etária: os juvenis (maiores de três anos) raramente foram vistos brincando com os infantes. A Brincadeira Locomotora só foi observada nos infantes mais novos - e dois infantes tentaram brincar com um quati (Carvalho, Resende \& Ottoni 2001).

\subsection{Proximidade, brincadeira social e observação da atividade dos coespecíficos}

No estudo de Resende e colaboradores (Resende, Izar \& Ottoni 2004), consideramos "Brincadeira Social" quaisquer interações não-agonísticas envolvendo correr, perseguir, morder, cutucar, rolar ou saltar na direção do parceiro ("Play fighting" ou "rough-and-tumble play" ["brincadeira turbulenta"]). A Brincadeira Social representou cerca de 4\% do tempo de amostragem focal, sendo que adultos e subadultosbrincaram significativamente menos $(0.08 \%)$ 
que infantes e juvenis $(4.8 \%)^{25}$.

\subsubsection{Associação entre brincadeira social e quebra de cocos}

Analisamos, nos dados das observações de Animais Focais de Resende (2004), as taxas de ocorrência de Brincadeira Social ou Quebra (Inepta, Adequada, Proficiente ou Não-determinada) de cocos, isoladamente, e de eventos em que estes comportamentos ocorriam em seqüência imediata ou em ciclos intercalados. Esta intercalação, no entanto, era menos característica dos infantes (com episódios de "quebra" [Inepta, QI] menos freqüentes e menor número de indivíduos) ou dos adultos (cujos episódios de Quebra eram de duração mais curta) que dos juvenis, que costumam formar "subgrupos" de brincadeira (Izar 1994).

As díades de brincadeira formadas entre macacos da mesma idade e de idades diferentes (com diferença de idade de 12 meses ou mais) aparecem numa proporção de praticamente 1:1. Quando normalizamos as díades formadas em função das díades possíveis, levando em conta as freqüências de episódios de brincadeira, não foi possível registrar preferência por parceiros da mesma idade ou de idade diferente $\left(\chi^{2}=0.208\right.$, g.l. $\left.=1, p=0.6483\right)$. Já ao considerar o tempo médio de brincadeira por díades dentro das categoria "mesma idade" e "idade diferente", notamos, como no estudo anterior, que os macacos passaram mais tempo brincando com coetâneos do que com os outros indivíduos $\left(\chi^{2}=2742.636, \mathrm{gl}=1, \mathrm{p}<0.0001\right)$.

\footnotetext{
25 Não incluímos nestas análises, por motivos óbvios, episódios de brincadeira "social" interespecíficos. Embora a maioria das interações entre os macacos-prego e os quatis do PET fossem de natureza agonística, não havia predação e, eventualmente, eram observados episódios de catação ou de brincadeira. De um total de 62 episódios de interações nãoagonísticas com quatis observados nos dois primeiros estudos com o grupo da Área de Preservação (Mannu 2002, Resende 2004), 26 puderam ser claramente identificados como lúdicos em função da exibição da "cara de brincadeira" pelos macacos. Infantes e juvenis brincaram com quatis jovens e adultos. A resposta destes pode ser registrada em 14 eventos: em 2 eles não reagiram, em 2 tentaram escapar, mas em 10 casos, responderam de maneira aparentemente positiva (em 8 destes, se tratava de um quati jovem), sendo que 3 eventos foram iniciados por quatis (Resende et al 2004).
} 


\subsubsection{Correlações entre Brincadeira Social, Proximidade e Observação}

A Proximidade Social foi medida através dos dados das Varreduras Focais, realizadas ao final de cada sessão de observação da atividade de um Animal Focal, quando eram registrados os outros indivíduos próximos, num raio de $1 \mathrm{~m}$ e 5m de distância). Já a Brincadeira Social foi quantificada a partir das interações registradas durante as observações dos Animais Focais.

Os dados referentes à identidade dos indivíduos nas díades de brincadeira $^{26}$ foram transformados em uma matriz $\mathrm{n} \times \mathrm{n}$ ( $\mathrm{n}=$ indivíduos) usada para calcular o Índice de Similaridade de Jaccard (J):

$$
J_{(x, y)}=a /(a+b+c)
$$

(onde $\mathrm{a}=$ tempo de brincadeira entre $\mathrm{x}$ e $\mathrm{y}, \mathrm{b}=$ tempo que $\mathrm{x}$ brincou com outros que não $y, c=$ tempo que y brincou com outros que não $x$ ).

Os registros de proximidade de cada Varredura Focal foram transformados numa matriz $\mathrm{n} \times \mathrm{p}$ (indivíduos $\mathrm{x}$ varreduras, onde " 1 " indicava a presença e "0" a ausência), a qual foi convertida em uma matriz $n \times n$ (indivíduos $\mathrm{x}$ indivíduos) com os índices de Jaccard (onde $\mathrm{a}=$ freqüência de registros com $x$ e y juntos; $b=$ freqüência de registros com $x$ mas não $y$ presente e $c=$ freqüência de registros com y mas não $x$ presente).

Estas "matrizes de similaridade" para Proximidade e Brincadeira Social foram transformadas em "matrizes de dissimilaridade" usando-se os valores complementares dos índices de Jaccard (1- J) (Izar \& Sato 1997, Izar 1994), a partir das quais pudemos "mapear”, através de Árvores Geradoras Mínimas, as relações mais fortes entre os membros do grupo e comparar as estruturas observadas nestas matrizes (Resende, Izar \& Ottoni 2004).

A Observação de Coespecíficos era computada, nas amostragens focais e nos registros de "Todas as Ocorrências" de quebra de cocos, quando um indivíduo orientava prolongadamente a face em direção a outro, distante no

\footnotetext{
26 Agrupamentos de mais de dois indivíduos brincando juntos foram tratados como várias díades.
} 
máximo 1 metro, sendo registrada a atividade do "alvo"27. A partir destes dados, construímos uma matriz assimétrica ("alvos" x "observadores") de Observação e outra simétrica $(n \times n)$, onde o valor de cada célula representa a associação de cada díade nos episódios de Observação. As correlações destas matrizes de Observação, Proximidade e Brincadeira foram calculadas com o Teste Tau Kr (Hemelrijk 1990a, 1990b ${ }^{28}$ ).

Para cada indivíduo, foram calculados, a partir das Árvores Geradoras Mínimas de Proximidade e Brincadeira Social, os "Graus de Vértices" (vertice degrees, número de outros indivíduos ao qual um deles está ligado), uma medida da sua "Popularidade". Para verificar se os mais "populares" eram mais observados, calculamos as correlações entre as freqüências como "alvos" de Observação e os GVs de Proximidade e Brincadeira Social.

\subsubsection{Resultados e discussão}

Os adultos e os juvenis eram "alvos" de observação significativamente mais freqüentes que os infantes (Kruskal-Wallis, $p=.027$; Mann-Whitney: IxA, $p=.013$, IxJ, p=.014), mas não encontramos diferenças significativas entre a observação de "alvos" adultos e juvenis, mesmo considerando-se apenas a observação de episódios de quebra de cocos, embora a taxa individual de episódios protagonizados por estes últimos tivesse sido bem maior que a dos adultos (lembrando que nos referimos aqui à freqüência, e não à qualidade dos episódios).

As freqüências de Observação de coespecíficos não se distribuíram ao acaso entre as faixas etárias (Kruskal-Wallis, $p=0.002$ ): juvenis e infantes foram os principais observadores (Mann-Whitney $\mathrm{U}$ : adultos e infantes, $\mathrm{z}=-$ 2.837, $p=0.05$; adultos e juvenis, $z=-2.997, p=0.03$ ). Na maioria dos eventos,

\footnotetext{
${ }^{27}$ Em função do método descrito, há um viés em favor da "observação de quebra de cocos", mas a categoria "Observação de Coespecíficos", conforme definida neste estudo (Resende, Izar \& Ottoni 2004) incluiu qualquer atividade do indivíduo observado (diferentemente da Observação da Quebra de cocos em Ottoni, Resende \& Izar 2005).

${ }^{28}$ Ao lidarmos com díades observacionais, cada indivíduo pode reaparecer em vários pares, levando à dependência estatística. Para contornar este problema, empregamos, para calcular a correlação entre as matrizes de Observação, Proximidade e Brincadeira, o teste $T a u K_{r}$ - onde $\mathrm{K}_{\mathrm{r}}$, derivado do índice de correlação Tau, de Kendall, mede a correlação entre as linhas de duas matrizes.
} 
os observadores eram pelo menos um ano mais novos que os "alvos" (83\%), e apenas $6.4 \%$ dos eventos envolveram observadores mais de um ano mais velhos que os "alvos". Corrigindo-se os dados em função do número de díades de observação possíveis em cada caso (sujeitos de mesma idade / observadores mais velhos / "alvos" mais velhos), verificamos que as díades com observadores mais novos ocorreram numa freqüência (ajustada) 2.35 vezes maior que as díades de mesma idade (Goodness-of-fit: $\chi^{2}=63.966$; g.l. $=2 ; p<0.0001)$.

O juvenil mais observado por indivíduos mais velhos, Darwin, não foi 0 que exibiu a taxa de quebra mais alta, mas sim, o que obteve os maiores GVs de Brincadeira Social e Proximidade. No entanto, considerando-se os "alvos" de observação em todos os eventos e o número de ligações nas AGMs, não encontramos correlação entre Popularidade e Freqüência como "alvo" de Observação: Darwin, que tinha o GV mais alto para Brincadeira Social e o segundo mais alto para Proximidade, foi apenas o sexto colocado no ranking dos indivíduos observados (8\% dos eventos), ficando atrás de sujeitos mais velhos, um padrão de escolhas que poderia tanto refletir um maior interesse "intrínseco" pelas atividades dos mais velhos, quanto uma capacidade de discriminar, nos "alvos" potenciais de observação, alguma característica correlacionada com a idade.

Dentro do universo das díades observadores/"alvos", não encontramos, considerando-se as matrizes assimétricas, correlações significativas entre Proximidade e Observação (Tau $K_{r}, p=.1334$ ), nem entre Observação e Brincadeira Social (Tau $K_{r}, p=.4468$ ), apesar de algumas díades de observação serem parcerias preferenciais de brincadeira: os macacos não necessariamente observaram os mesmos indivíduos com quem brincaram.

Encontramos uma correlação significativa entre as díades de proximidade e as díades de observação apenas na matriz simétrica, indicando que a tolerância social propicia a observação (e, conseqüentemente, a aprendizagem socialmente enviesada dos comportamentos observados), mas o valor desta correlação foi baixo, sugerindo que os macacos não observavam, simplesmente, aqueles com quem andavam juntos, mas também, em algum grau, procuraram ativamente a quem ou a que observar. Além disso, as análises utilizando a matriz simétrica de Observação não levavam em conta os 
diferentes papéis de Observadores e "Alvos". Em função destas considerações, tornamos a analisar os dados do estudo original (Resende 2004), com alguns refinamentos na análise estatística e restringindo a análise aos eventos de observação da quebra de cocos (Ottoni, Resende \& Izar 2005).

\subsection{Reexaminando a escolha dos "alvos" de observação por coespecíficos}

Como relatamos anteriormente, quase um quarto dos episódios de quebra de cocos observados no estudo sobre o desenvolvimento do uso de ferramentas pelos macacos do PET foram alvo de observação por coespecíficos (Resende \& Ottoni 2002). A ausência de correlações significativas entre a Observação de Coespecíficos e as variáveis Proximidade Social e Brincadeira Social quando a direção do comportamento (o papel dos animais como Observadores ou "Alvos" de observação) era levada em conta indicava que as taxas de observação dos "alvos" potenciais não eram apenas um reflexo passivo dos vínculos afiliativos entre companheiros de brincadeira ou outras atividades (Resende, Izar \& Ottoni 2004): os macacos-prego aparentemente buscavam ativamente observar determinadas atividades "atraentes" - como a quebra de cocos. Esta percepção foi confirmada pela correlação significativa entre a Observação e a Taxa de Quebra ${ }^{29}\left(\right.$ Tau K $_{\mathrm{r}}$ Parcial $\left.=0.347 ; \mathrm{P}_{\mathrm{r}}=0.0025\right)$.

Isso nos levou à questão seguinte: será que os macacos observam qualquer um dentre os "quebradores" disponíveis ou haveria uma escolha ativa, baseada em características particulares dos "alvos" potenciais de observação? Procedemos, assim, a uma nova análise das correlações entre os dados referentes à Observação, Proximidade Social, Brincadeira Social, Idade, Dominância, Taxa de quebra de cocos e Proficiência na quebra (Ottoni, Resende \& Izar 2005).

Cada evento observacional correspondeu, nesta nova análise, à

\footnotetext{
${ }^{29}$ A Taxa de Quebra corresponde à Freqüência Absoluta de episódios de Quebra, corrigida em função do tempo de permanência no grupo (indivíduos que deixaram o grupo ou voltaram a ele, não tendo ali permanecido durante todo o período da coleta de dados).
} 
atividade de um observador durante um episódio de quebra (executado por um "Alvo"). Os eventos observados por coespecíficos (131 dentre 570 episódios de quebra de cocos) envolveram, em 95\% dos casos, a presença de um único observador, com a exceção de 6 eventos (2 observadores, $N=5 ; 3$ observadores, $\mathrm{N}=1)^{30}$.

A Proficiência de cada indivíduo ("Alvo" potencial de observação) foi calculada dividindo-se sua freqüência absoluta de episódios de quebra bemsucedidos $(\mathrm{QP})$ pelo número total de episódios $(\mathrm{QP}+\mathrm{QA}+\mathrm{QI})^{31}$.

As correlações entre as matrizes foram calculadas utilizando-se o teste Tau $\mathrm{K}_{\mathrm{r}}$. Correlacionamos uma matriz quadrada assimétrica com as freqüências absolutas de observação da quebra de cocos (Observadores x Alvos) com matrizes quadradas de Proximidade Social (onde as células representam o índice de proximidade de Jaccard para cada díade; v. acima), de Idade, de Dominância e de ranking de Proficiência. Nestas matrizes, o valor das caselas se refere aos indivíduos, não às díades; assim aos indivíduos-alvo era associado o mesmo valor em toda a coluna; na matriz de Idade, usamos a ordenação relativa entre os indivíduos, já que em alguns casos não era conhecida a idade precisa, em termos absolutos (casos duvidosos foram tratados como empates). A ordem de Dominância se baseou no número de vitórias e derrotas entre cada díade em episódios agonísticos (empates resolvidos com base na transitividade) ${ }^{32}$; na matriz de Proficiência foram usados os índices individuais (calculados como indicado acima) - mas a correlação de postos só leva em conta a ordenação relativa entre os

\footnotetext{
${ }^{30}$ Assim, há uma pequena diferença entre o total de episódios de quebra $(\mathrm{N}=131)$ e o de eventos observacionais $(\mathrm{N}=138)$.

${ }^{31} \mathrm{QP}=$ Quebra Proficiente; QA = Quebra Adequada; QI = Quebra Inepta (v. Capítulo 3 para definições). Parte das análises em Resende (2004) difere das apresentadas em Ottoni, Resende \& Izar (2005) em função da redefinição de algumas variáveis (a Proficiência passou a ser calculada como a razão entre episódios de Quebra Proficiente e o total de episódios de quebra, descontados os episódios de Quebra Não-determinada - onde não foi possível observar se a quebra foi ou não proficiente).

${ }^{32} \mathrm{O}$ ranking de hierarquia se baseou em dados sobre a dinâmica social do grupo coletados, no mesmo período, por Ferreira (2003).
} 
indivíduos ${ }^{33}$.

\subsubsection{Resultados e discussão}

Na ausência de qualquer escolha ativa dos Alvos de observação, deveria haver uma relação direta entre a proximidade social e as oportunidades de observação, com os Observadores assistindo à quebra de cocos pelos seus parceiros habituais, mas nesta nova análise não encontramos correlação significativa entre Observação e Proximidade Social (Tau $K_{r}$ Parcial=-0.125; $\left.\mathrm{p}_{\mathrm{r}}=0.8486\right)$; a correlação significativa entre Observação e a Taxa de Quebra ( $\mathrm{v}$. acima) confirmava uma escolha ativa deste comportamento como objeto de observação; não nos parecia, entretanto, que a Observação refletisse apenas a freqüência com que os Alvos potenciais exibiam o comportamento de quebra.

Se, por um lado, a atividade predominantemente "inepta" de juvenis mais novos ou infantes não atraía tantos observadores, já havíamos tido a oportunidade de notar (Sestini \& Ottoni 2002) que os infantes em um grupo cativo de macacosprego eram extremamente interessados na atividade do macho dominante; assim, examinamos a correlação entre a Observação e a hierarquia de Dominância, mas esta também não se mostrou significativa (Tau $K_{r}$ Parcial $\left.=0.148 ; p_{r}=0.1824\right)^{34}$. E embora os Observadores fossem em geral mais novos que os seus Alvos (goodness-of-fit: $\chi^{2}=63.966$, g.l. $=2, p<0.0001$ ), como relatado por Biro et al (2003) em chimpanzés, não encontramos correlação significativa entre Observação e ordem de Idade (Tau $K_{r}$ Parcial $=0.076$; $\left.\mathrm{p}_{\mathrm{r}}=0.3123\right)$.

Voltamos nossa atenção, então, para fatores ligados ao desempenho na quebra de cocos, em si, e verificamos que, em cerca de $76 \%$ das díades

\footnotetext{
${ }^{33}$ Aos indivíduos que nunca realizaram quebra de cocos, foram atribuídos zeros estruturais na matriz de freqüência absoluta de observação; estes zeros estruturais eram eliminados com o uso de uma matriz "dummy" de valores faltantes (Hemelrijk 1990b), onde eram atribuídos aos zeros estruturais um número elevado (não presente na matriz real), sendo atribuídos zeros a todas as outras caselas. Este procedimento tem por objetivo evitar que os zeros estruturais i.e., animais que não podiam ser observados porque não quebravam cocos - fossem contados como "quebradores" não-observados. O Tau $\mathrm{K}_{\mathrm{r}}$ Parcial, derivado do Tau Parcial de Kendall, mede a associação entre duas matrizes mantendo constante o efeito de uma terceira matriz constante (Hemelrijk 1990a, 1990b).

${ }^{34}$ Mas isso não descarta um efeito exclusivamente associado ao macho dominante.
} 
Observador/Alvo (51 em 67), o Alvo era mais proficiente que o Observador (goodness-of-fit: $\chi^{2}=18.28$, g.I.=1, $p<0.0001$ ).

Numa primeira análise encontramos uma correlação geral entre Observação e Proficiência (Pearson=0.593, $\mathrm{p}=0.006$ ). Para eliminar eventuais vieses devido a poucos indivíduos altamente proficientes e altamente observados (super-representados na amostragem), aplicamos o teste $T a u K_{r}$ na comparação destas variáveis e ainda assim encontramos uma correlação significativa (Tau $\mathrm{K}_{\mathrm{r}}$ Parcial $_{\mathrm{xyz}}=0.232 ; \mathrm{p}_{\mathrm{r}}=0.0495$ ). Finalmente, verificamos que isso não era conseqüência de uma correlação entre a Proficiência e a Freqüência Absoluta de Quebra de cocos, já que esta última não era significativa (Tau $\mathrm{K}_{\mathrm{r}}$ Parcial $\left._{\mathrm{xyz}}=0.114 ; \mathrm{p}_{\mathrm{r}}=0.2569\right)$.

Estes resultados indicavam uma escolha ativa dos Alvos de observação, sugerindo fortemente que a proficiência dos Alvos potenciais de observação na quebra de cocos estivesse sendo levada em conta pelos observadores. Não é preciso supor que haja um propósito ou motivação para aprender com um coespecífico mais hábil por trás desta escolha, já que os retornos diferenciais no scrounging podem fornecer uma causa proximal mais parcimoniosa para a observação seletiva - ainda que isso certamente contribua para a aprendizagem, como efeito colateral.

Este grupo de macacos-prego é, na maior parte do tempo, uma sociedade relativamente relaxada (Ferreira 2003), onde os indivíduos mais jovens são altamente tolerados. Não foram registrados eventos agonísticos durante os episódios de Observação de Quebra. Devido à tolerância dos Alvos à proximidade dos Observadores, estes tinham fartas oportunidades de observar os "quebradores" proficientes. O "scrounging" ocorreu em 35\% ( $N=20)$ dos episódios confirmadamente bem-sucedidos de quebra de cocos em que havia ao menos um Observador coespecífico presente $(\mathrm{N}=57)$. Em 15 destes episódios, o "scrounging" foi tolerado pelo Alvo ("Imediato"); nos 5 casos restantes, o "scrounging" se deu após a partida do Alvo ("scrounging" mediato). Conseqüentemente, ainda que possam haver outras motivações subjacentes (lúdicas, por exemplo), simples processos associativos ou de reforçamento podem explicar a tendência dos macacos-prego - jovens em particular - a assistir aos "quebradores" em ação. 


\subsection{Replicações do estudo sobre escolha dos Alvos de observação com o grupo do PET}

Uma limitação séria do estudo original decorria do fato de se tratar de uma meta-análise, não tendo a coleta de dados sido desenhada para examinar a escolha dos "alvos" de observação. Por esse motivo, uma nova amostragem foi realizada com o grupo da Área de Preservação do PET, entre abril de 2006 e abril de 2007. Nos dados do primeiro estudo, uma vez que os episódios de quebra de cocos eram registrados tanto durante observações pelo método do Animal Focal (mais detalhadas) quanto oportunisticamente, pelo método de "Todas as Ocorrências", em muitos episódios, no segundo caso, não foi possível determinar o sucesso - e onde houve sucesso, este era definido como a quebra de (pelo menos) um coco, não sendo possível especificar a quantidade exata de cocos quebrados por episódio bem-sucedido. Assim, a proficiência dos indivíduos era avaliada apenas em função da taxa de episódios com ao menos um coco quebrado.

Nesta replicação, a atividade nos sítios de quebra foi registrada por um procedimento que denominamos "Eventos Focais", para que fosse possível quantificar melhor a proficiência dos manipuladores e as taxas de "scrounging" pelos observadores. Um Evento Focal (filmado para posterior transcrição) tinha início quando um macaco chegava a um sítio de quebra e terminava quando este - e qualquer outro indivíduo (como um observador) que tivesse se juntado a ele no sítio - tivesse $(m)$ se afastado (mais de $2 \mathrm{~m}$ ) por mais de um minuto. Dependo das atividades exibidas pelo sujeito que chegava ao sítio, o evento era classificado como um episódio Exploratório ou de Quebra (havendo percussão de "martelos" contra a "bigorna"); dependendo do desempenho do sujeito e dos resultados, os episódios de quebra foram classificados, como no estudo anterior, como de Quebra Proficiente, Adequada ou Inepta (com este procedimento, não houve "Quebra Não-determinada"). Durante os episódios de quebra, eram registrados os comportamentos dos manipuladores (tais como o tempo de manipulação, numero de golpes com o "martelo", número de cocos transportados, posicionados sobre a "bigorna", quebrados e ingeridos) e dos observadores coespecíficos - como a manipulação de pedras e cocos, exibição 
de gestos empáticos e ocorrência de "scrounging" imediato ou mediato (i.e., na presença de um manipulador tolerante ou após a sua partida). O "scrounging" mediato, naturalmente, podia ocorrer tanto em episódios de Quebra de cocos quanto em episódios Exploratórios.

Para quantificar as relações de proximidade entre os indivíduos, foram realizadas "Varreduras Focais", registrando-se os indivíduos que se encontravam em contato direto, a um metro e a 10 metros do sujeito focal (Altmann 1974).

Para um estudo paralelo sobre a transferência de alimento entre indivíduos em outros contextos que não o da quebra de cocos, foram registradas em vídeo "Todas as Ocorrências" de episódios que pudessem resultar em Transferência Direta (quando o Receptor tomava a comida diretamente das mãos ou pés do Doador ou lambia seu rosto ou pelo) ou Transferência Indireta (recolher comida largada pelo Doador, numa distância de até 2 metros, ainda na presença deste) $)^{35}$.

Em função de alterações na composição do grupo (migrações, nascimentos e mudanças de faixa etária), os dados foram divididos, para a análise, em três períodos (para mais detalhes v. Coelho 2009).

\subsubsection{Resultados e discussão}

A maioria (79.8\%) dos 475 Eventos Focais registrados envolveu o uso percussivo de pedras nos sítios (constituindo episódios de Quebra independentemente da qualidade do desempenho ou dos resultados) sendo os restantes classificados como "Exploratórios", envolvendo alguma manipulação incipiente (não-percussiva) de elementos do sítio (13.5\% dos 96 episódios) ou apenas "scrounging" mediato (86.5\% dos episódios "Exploratórios"). A manipulação não-percussiva nos sítios, além de infreqüente, foi realizada apenas por juvenis e - principalmente - infantes (embora a diferença entre juvenis e infantes não tenha sido significativa, assim como não o foi a diferença

\footnotetext{
35 Dos 113 episódios de Transferência de Alimento registrados, 61\% foram de Transferência Direta. A Transferência Indireta ocorreu em proporções semelhantes para díades aparentadas e não-aparentadas; já no caso da Transferência Direta, 70\% dos episódios podem ser explicados por seleção de parentesco, já que $57.5 \%$ se deram entre mãe e filhote, $5.3 \%$ entre irmãos e $8 \%$, entre parentes de $1^{\circ}$ grau (avós e tias como Doadoras; Coelho 2009).
} 
entre os sexos).

O "scrounging" mediato nos Episódios Exploratórios (que não envolve, naturalmente, observação direta da quebra), algo não registrado nos estudos anteriores, foi executado em proporções semelhantes por machos e fêmeas e, numa distribuição não significativamente distinta, por infantes, juvenis e adultos (embora estes tenham sido responsáveis por cerca do dobro dos eventos que os infantes).

Os machos foram responsáveis, no total, por mais episódios de quebra de cocos (66.2\%) que as fêmeas, mas essa diferença só foi estatisticamente significativa no segundo dos três períodos em que os dados foram subdivididos para a análise (em parte, porque o teste de Kruskal-Wallis não leva em conta as freqüências absolutas, mas apenas as posições relativas dos indivíduos no ranking de desempenho; para uma discussão mais aprofundada desta questão, v. Coelho 2009). Em termos absolutos, os adultos foram responsáveis pela maioria dos episódios de quebra de cocos (81.3\%), seguidos pelos juvenis $(17.2 \%)$ e infantes (1.6\%). No que se refere às comparações através do ranking dos indivíduos na quebra (Kruskal-Wallis), entretanto (inclusive pelo grande número de indivíduos com freqüência nula), essas diferenças não foram significativas - como observado por Resende (2004) e no segundo período da coleta de dados de Mannu (2002; no primeiro período, os juvenis se mostraram significativamente mais ativos).

Dentre os 396 episódios de Quebra de Cocos, 73\% foram de Quebra Proficiente; em $16.2 \%$ deles, "martelos" e cocos foram manipulados adequadamente sobre a "bigorna" mas a quebra não se consumou por um motivo qualquer (Quebra Adequada), e 10.8\% dos episódios foram classificados como "Quebra Inepta". Os infantes realizaram apenas Quebras Ineptas. Os juvenis exibiram uma maior variabilidade inter-individual quanto às freqüências de Quebra Inepta, Adequada ou Proficiente. Já os adultos realizaram quase que exclusivamente Quebras Proficientes.

Machos e fêmeas foram Alvos de Observação nos 3 períodos; a diferença entre os gêneros só se mostrou significativa - em favor dos machos no Período $C$, refletindo as freqüências de quebra exibidas por uns e outras. Infantes não foram Alvos de Observação, mas não houve diferenças 
significativas entre os rankings como Alvos de adultos e juvenis, diferentemente do registrado por Resende (2004). Comparando-se o tempo total de observação por coespecíficos, verificamos que David, então o macho dominante, foi o principal Alvo, mas esta diferença desaparece nos valores relativos, ou seja, é uma conseqüência da atividade mais intensa do dominante nos sítios de quebra.

Os Observadores eram machos e fêmeas, tendo sido encontrada uma tendência a uma diferença significativa em favor das fêmeas apenas no Período $A$. Os juvenis tenderam a ser Observadores mais freqüentes que os adultos neste Período, mas a distribuição não se mostrou significativamente diferente (Kruskal-Wallis) entre as faixas etárias nos períodos B e C. No Período $B$, isso provavelmente se deve à grande variação individual dentro de cada faixa, uma vez que, considerando-se as freqüências relativas ${ }^{36}$ de episódios de observação por faixa etária, tanto infantes quanto juvenis foram Observadores mais do que o dobro de vezes que os adultos.

Analisando-se as associações entre Alvos e Observadores, verificamos que os machos adultos foram os principais Alvos de observação das fêmeas adultas e os adultos, machos e fêmeas, foram os principais Alvos de observação de juvenis e infantes.

Alguns indivíduos (Cisca, David e Medeiros) se destacaram como Alvos, tanto nas freqüências de observação quanto no número de Observadores diferentes. Os valores totais, entretanto, "mascaram" uma série de vieses relacionados a especificidades das relações sociais no grupo. A fêmea Cisca, por exemplo, era observada principalmente por seus filhotes - mas isso não se aplica a todas as fêmeas. Já as fêmeas no cio seguem o macho dominante e, em conseqüência, o observam muito mais, o que afeta os totais de observação de machos por fêmeas.

Para avaliar se, como no estudo anterior, havia correlações entre o desempenho dos "quebradores" e a sua escolha como Alvos de Observação, empregamos dois índices de eficiência na quebra de cocos: a Taxa de Proficiência e a Taxa de Produtividade.

A Taxa de Proficiência foi obtida dividindo-se o número de episódios de

\footnotetext{
${ }^{36}$ Corrigidas em função do número de indivíduos em cada faixa etária.
} 
Quebra Proficiente pela Freqüência Absoluta de episódios de quebra de cocos (Quebra Proficiente + Quebra Adequada + Quebra Inepta) - uma medida equivalente à utilizada anteriormente (Ottoni, Resende \& Izar 2005 ${ }^{37}$ ). Não encontramos diferenças significativas entre a Proficiência de machos e fêmeas, mas sim entre as faixas etárias, sendo os adultos mais proficientes que os juvenis e estes, que os infantes (Kruskal-Wallis, $\mathrm{H}=9.166 ; \mathrm{g} . \mathrm{I} .=2 ; \mathrm{p}=0.002$ ).

Ao contrário do verificado no estudo anterior, entretanto, esta variável não se mostrou útil para distinguir adequadamente o desempenho dos indivíduos, já que as diferenças foram pequenas, muitos deles exibindo a taxa máxima. De qualquer modo, essa variável foi calculada apenas para permitir comparações entre os estudos, já que neste caso dispúnhamos de uma medida mais precisa da produtividade de cada Alvo potencial de Observação.

A partir da análise dos registros em vídeo, foi possível obter o número efetivo de cocos quebrados em cada episódio. Em termos absolutos, três indivíduos, David (o dominante), Medeiros e Suspeito foram responsáveis por mais da metade dos cocos quebrados registrados neste estudo. Dividindo-se estes totais pela freqüência de episódios, obtivemos as Taxas de Produtividade individuais. Machos e fêmeas não se mostraram diferentes quanto à Produtividade. Os adultos foram significativamente mais produtivos que os juvenis (Kruskal-Wallis, $\mathrm{H}=11.015$; g.I.=1; $\mathrm{p}=0.004$ ) e que os infantes (KruskalWallis, $\mathrm{H}=11.680 ; \mathrm{g} . \mathrm{I}=1 ; \mathrm{p}=0.02)$, mas a diferença entre juvenis e infantes não atingiu a significância.

Finalmente, para reavaliar as questões a respeito da escolha dos Alvos de Observação suscitadas pelo estudo anterior, foram realizados os testes de correlação (Tau Kr, Hemelrijk 1990a, 1990b) entre a matriz de Observação e as matrizes de Proximidade (contato/ 1m/ 10m), Brincadeira, Catação, Idade, Freqüência de Quebra de cocos, Duração acumulada de Quebra de cocos, Proficiência, Produtividade, Deslocamento (de um indivíduo por outro no sítio de quebra), Hierarquia (baseada em episódios agonísticos) e "Scrounging" Imediato, para cada um dos três Períodos. As matrizes de Observação, Catação, Deslocamento e "Scrounging" Imediato são assimétricas, por serem

\footnotetext{
${ }^{37}$ Aqui, em função da metodologia de observação empregada, não havia QN (Quebra Nãodeterminada).
} 
direcionais (os dois indivíduos têm papéis complementares), enquanto que as matrizes de Proximidade e Brincadeira são simétricas. As matrizes restantes, que se referem a características individuais, são construídas repetindo-se o valor ao longo da coluna referente ao indivíduo em questão ${ }^{38}$.

Como anteriormente, encontramos uma correlação significativa entre Observação e Proficiência e entre Observação e Produtividade, em todos os Períodos. As correlações mais fortes ${ }^{39}$ foram as encontradas entre Observação e "Scrounging" Imediato, o que vai ao encontro da hipótese do "scrounging" como motivação proximal para a observação da quebra.

Por outro lado, encontramos, desta vez (apenas para o Período B) uma correlação significativa entre Observação e Proximidade (1m), aparentemente decorrente da observação intensiva do macho dominante, que exibe altos índices de proximidade com a maioria dos indivíduos do grupo (especialmente fêmeas e infantes), e da observação de Cisca por seus filhotes. No mesmo período, foi também significativa a correlação da Observação com a Brincadeira - mas, curiosamente, não com a Catação.

A Observação mostrou-se, novamente, em todos os períodos, significativamente correlacionada à Freqüência de Quebra de cocos (e também com o tempo de atividade do "quebrador" no sítio). No entanto, no primeiro estudo a correlação entre Observação e Proficiência não podia ser (inteiramente) explicada por uma correlação entre Proficiência e Freqüência de Quebra, uma vez que esta não era significativa. De modo geral, os Alvos de Observação foram os "quebradores" mais ativos (Freqüência e Tempo de Quebra), mais proficientes e mais produtivos - mas neste novo estudo, a Proficiência se correlacionou significativamente com a Freqüência de quebra nos três períodos (bem como com o ranking de Idade e com o Deslocamento), o que não nos permite afirmar que tenha havido um efeito independente da Proficiência sobre a escolha dos Alvos de Observação.

\footnotetext{
${ }^{38}$ Matrizes hipotéticas, na terminologia de Hemelrijk (1990a, 1990b).

${ }^{39}$ V. Tabela 16 em Coelho 2009.
} 


\subsection{Discussão geral}

Tanto o "scrounging" quanto as oportunidades de aprendizagem podem ser maximizados por uma boa escolha dos Alvos de observação, seja esta baseada em conhecimento sobre a proficiência relativa dos Alvos potenciais (possibilitando aos Observadores avaliar as diferenças potenciais no retorno ao se observar "quebradores" de habilidades desiguais) ou em quaisquer regras mais simples de decisão que produzam um resultado semelhante.

As informações que vêm se acumulando sobre o uso complexo de ferramentas em animais não-humanos tem implicações tanto no nível individual, quanto no nível social. $\mathrm{Na}$ esfera social, estes dados nos permitem testar algumas hipóteses sobre as relações entre dinâmica social e transferência social de informação (King 1991; Coussi-Korbel \& Fragaszy 1995; van Schaik Deaner \& Merrill 1999). Na escala individual, colocam diversas questões (testáveis) sobre as bases cognitivas da invenção e da aprendizagem do uso de ferramentas em cada espécie particular, tais como o efetivo grau de compreensão das relações causais ou das "potencialidades" dos objetos como ferramentas (Visalberghi \& Limongelli 1994, Hauser et al 1999; Fujita et al 2003, Evans \& Westergaard 2004; Santos et al 2003).

As "hipóteses" da "Inteligência Social", de acordo com as quais a evolução da cognição primata foi movida pelas pressões da vida em sociedades complexas ${ }^{40}$, têm recebido o apoio de um crescente volume de evidências favorecendo a idéia de que os pongídeos e os macacos do Velho Mundo entendem suas relações sociais e utilizam, em uma série de processos de tomada de decisão, seu conhecimento de diferenças hierárquicas ou de conexões afiliativas entre os membros do grupo (Byrne \& Whiten 1988; Cheney \& Seyfarth 1990) - ou mesmo suas diferentes competências na solução cooperativa de problemas (Melis, Hare \& Tomasello 2006). Por outro lado, processos sociais complexos não implicam necessariamente em níveis equivalentes de capacidade cognitiva individual (Strum, Forster \& Hutchins 1997; Johnson 2001). A reciprocidade na partilha de alimentos, por exemplo,

\footnotetext{
${ }^{40}$ Como a Hipótese da Inteligência Maquiavélica (Byrne \& Whiten 1988) e variantes (v. Ottoni 2009).
} 
não precisa estar baseada em uma "contabilidade" mental detalhada das interações passadas ("reciprocidade calculada"), mas pode ser explicada por uma modulação geral da predisposição para a partilha pela história de interações prévias ("reciprocidade de atitudes" - de Waal 2000, de Waal \& Berger 2000).

Evidências do tipo de "consciência triádica" (triadic awareness) implicada pela capacidade de um animal de entender alguns aspectos das relações entre dois companheiros de grupo (e daqueles consigo), foram obtidas em estudos experimentais com macacos do Velho Mundo (Dasser 1988; Cheney \& Seyfarth 1990; Silk 1999). Dentre as espécies do Novo Mundo, Perry, Barrett \& Manson (2004) mostraram que Cebus capucinus parecem exibir tal "consciência triádica", uma vez que tendem a solicitar para coalizões parceiros não apenas dominantes em relação a seus oponentes, mas ainda com relações melhores consigo que com os oponentes.

Os resultados do nosso primeiro estudo (Ottoni, Resende \& Izar 2005) sugeriam que os macacos-prego seriam capazes de discriminar seus companheiros de grupo de acordo com suas habilidades no uso de ferramentas, mostrando-se mais inclinados a observar os "quebradores" de cocos mais proficientes. O "scrounging", enquanto motivação proximal, otimiza as possibilidades de aprendizagem socialmente mediada, uma vez que ambos se beneficiam de uma estratégia de "observar o mais bem-sucedido" (Laland 2004). Estas preferências poderiam resultar em uma espécie de "hierarquia de prestígio" - distinta e independente da de dominância - análoga à proposta por Heinrich \& Gil-White (2001) como uma característica decisiva para a otimização da transmissão cultural humana. Qualquer que seja o mecanismo cognitivo subjacente, seja o processo de decisão resultante de alguma compreensão efetiva da hierarquia de proficiência relativa ou de simples histórias diferenciais de associação ou reforçamento ligadas a cada Alvo individual, esta capacidade poderia desempenhar um papel decisivo no estabelecimento do uso de ferramentas como uma tradição comportamental.

No entanto, se por um lado o novo estudo reforçou os resultados anteriores referentes a uma busca ativa pela observação de episódios de quebra de cocos, por outro, não pode confirmar ou desmentir os resultados referentes a uma discriminação dos "alvos" de observação potencial em função 
de seu desempenho. Trata-se do tipo de problema para o qual o laboratório, numa situação mais controlada, possivelmente será capaz de fornecer melhores respostas. Em parte, as diferenças encontradas entre os sucessivos estudos podem ser o reflexo de algumas mudanças na demografia da quebra de cocos no grupo ao longo dos últimos 12 anos.

\subsubsection{Uma possível história da disseminação do uso de ferramentas no grupo da Área de Preservação do PET}

No primeiro estudo (Ottoni \& Mannu 2001, Mannu 2002), os juvenis foram responsáveis pela maioria dos episódios de quebra de cocos cujos sujeitos foram identificados, mas havia enormes diferenças de proficiência mesmo entre juvenis de mesma idade (v. 2.4.3).

Este padrão de grandes diferenças individuais continuou a ser observado no estudo ontogenético desenvolvido entre 2000 e 2002 (Resende, 2004, Resende, Ottoni \& Fragaszy, 2008). Alguns dos juvenis mais proficientes do primeiro estudo haviam se tornado adultos, mas deixaram o grupo (ao menos temporariamente). Em média, os juvenis, machos subadultos e adultos mais jovens exibiram as maiores taxas de comportamento de quebra, seguidos pelos machos adultos mais velhos e juvenis mais novos. Entre as fêmeas, Física nunca foi vista quebrando cocos naquele estudo, mas por outro lado Janete, a melhor "quebradora" dentre as fêmeas no primeiro estudo, ainda era a fêmea mais ativa, e sua filha Vavá também se tornou uma "quebradora" muito proficiente. Naquele período da pesquisa, em suma, animais entre 4 e 6 anos de idade eram os usuários mais ativos de ferramentas. Numa situação em que os "quebradores" mais ativos não são os animais mais velhos e a variabilidade individual na proficiência é grande, não há "regras práticas" para escolher um "bom alvo" para observar - e alguma percepção das "qualidades" relativas dos "alvos" potenciais pode ser de grande valia.

Um padrão um tanto diferente foi observado, no entanto, tanto na replicação subseqüente no PET (Coelho 2009), quanto num estudo semelhante conduzido com um grupo selvagem no local de estudo do Projeto EthoCebus (v. Capítulo 5) na Fazenda Boa Vista, no Piauí (Ramos-da-Silva 2008; Coelho, Ramos-da-Silva \& Ottoni, 2008). No período de 2006/2007, no PET, adultos e 
subadultos passaram a ser os "quebradores" mais ativos, responsáveis pela maioria dos episódios de quebra de cocos (81.3\%), enquanto que os juvenis responderam por $17.2 \%$ e os infantes, por apenas $1.6 \%$.

Os dados mais recentes do PET sobre a demografia etária da quebra de cocos são mais semelhantes com o que tem sido observado em populações de Cebus libidinosus em ambientes de cerrado ou caatinga (Fragaszy et al 2004, Mannu \& Ottoni 2009), e nos ajudam a refletir sobre os padrões observados nos estudos anteriores, sugerindo que a quebra de cocos com o auxílio de ferramentas surgiu no grupo da Área de Preservação do PET pouco tempo antes de terem chegado a nós os primeiros relatos a respeito, talvez como "inovação" local ou, mais provavelmente, introduzida por algum dos indivíduos que migraram para o grupo, vindos dos grupos semi-cativos das ilhas do parque (o macho adulto Medeiros sendo um candidato bastante provável).

As mudanças na demografia do uso de ferramentas nas classes etárias se ajustam bem a certos padrões que Huffman e colaboradores (Huffman 1996; Huffman \& Hirata 2003) descreveram em macacos japoneses em seu estudo sobre a dinâmica das tradições comportamentais em primatas não-humanos (V. Capítulo 7), assim como à descrição de Inoue-Nakamura \& Matsuzawa (1997) sobre um episódio de difusão inter-grupal do uso de pedras para quebrar cocos numa população selvagem: sendo os juvenis do grupo do PET os observadores mais interessados e mais tolerados das atividades de um usuário hábil de ferramentas, eles se tornaram os "quebradores" mais ativos durante a "Fase da Transmissão" (Huffman 1996); à medida em que estes indivíduos foram ficando mais velhos, o padrão demográfico mudou (com algum retardo, em função das emigrações) para o que se observa costumeiramente para tradições já estabelecidas ("Fase da Tradição", Huffman, op.cit.), onde os adultos são os indivíduos mais proficientes e os "alvos" observacionais preferidos (no caso dos macacos-prego, especialmente o macho dominante) $)^{41}$.

No grupo da Área de Preservação do PET, algumas das fêmeas se tornaram bastante ativas na quebra de cocos, o que não é comum em grupos selvagens, mas que pode se dever a uma série de fatores, tais como o maior

\footnotetext{
${ }^{41}$ Ottoni et al 2009.
} 
tempo disponível (devido ao aprovisionamento), a falta de predadores terrestres e - talvez mais importante - o tamanho e a dureza dos cocos de jerivá, que são menores e mais fáceis de quebrar que a maioria dos cocos quebrados pelos macacos-prego selvagens no cerrado. Nestas populações, os cocos, em geral muito duros, são quebrados predominantemente pelos machos, mais pesados e fortes, mas as fêmeas podem ser usuárias de ferramentas bastante ativas ao processar outros tipos de sementes, mais fáceis de quebrar (Ramos-da-Silva 2008). 



\section{Capítulo 5: O uso de ferramentas por populações} selvagens de macacos-prego

$\mathrm{Na}$ época em que o primeiro estudo sobre o uso de ferramentas pelos macacos-prego do Parque Ecológico do Tietê estava sendo concluído (Ottoni \& Mannu 2001, Mannu 2002), já tínhamos informações mais que suficientes para supor que esse comportamento não fosse uma peculiaridade de um grupo provisionado, iniciado por indivíduos de origens obscuras e com intenso contato com humanos. Além de relatos anedóticos de campo mais antigos, como o de Fernandes (1991), já sabíamos, então, de um caso semelhante ao do PET em outro parque urbano (Rocha, Reis e Sekiama 1998) e das evidências indiretas dessa atividade entre grupos selvagens de $C$. libidinosus (Langguth \& Alonso 1997): os "sítios de quebra" que já nos eram tão familiares.

Assim, enquanto o estudo com os animais em semi-liberdade entrava em uma nova etapa, buscando um acompanhamento mais minucioso do desenvolvimento ontogenético do uso de ferramentas, o passo seguinte da pesquisa, estava claro, envolveria a busca de populações selvagens que utilizassem ferramentas, em condições que permitissem a observação direta em estudos de duração mais longa. Estas condições surgiram, quase simultaneamente, em duas localidades, distantes entre si cerca de $320 \mathrm{~km}$, no interior do Piauí (Figura 23).

\subsection{Os estudos na Fazenda Boa Vista}

As fotos de macacos-prego quebrando cocos com ferramentas, publicadas por Peter Oxford numa revista eletrônica da BBC, chamaram a atenção de Dorothy Fragaszy (University of Georgia, Athens, USA) e Elisabetta Visalberghi (Istituto 
di Scienze e Tecnologie della Cognizione, Roma, Itália), que entraram em contato com nossa equipe no início de 2003 para estabelecer a parceria que veio a constituir o Projeto EthoCebus ${ }^{42}$.

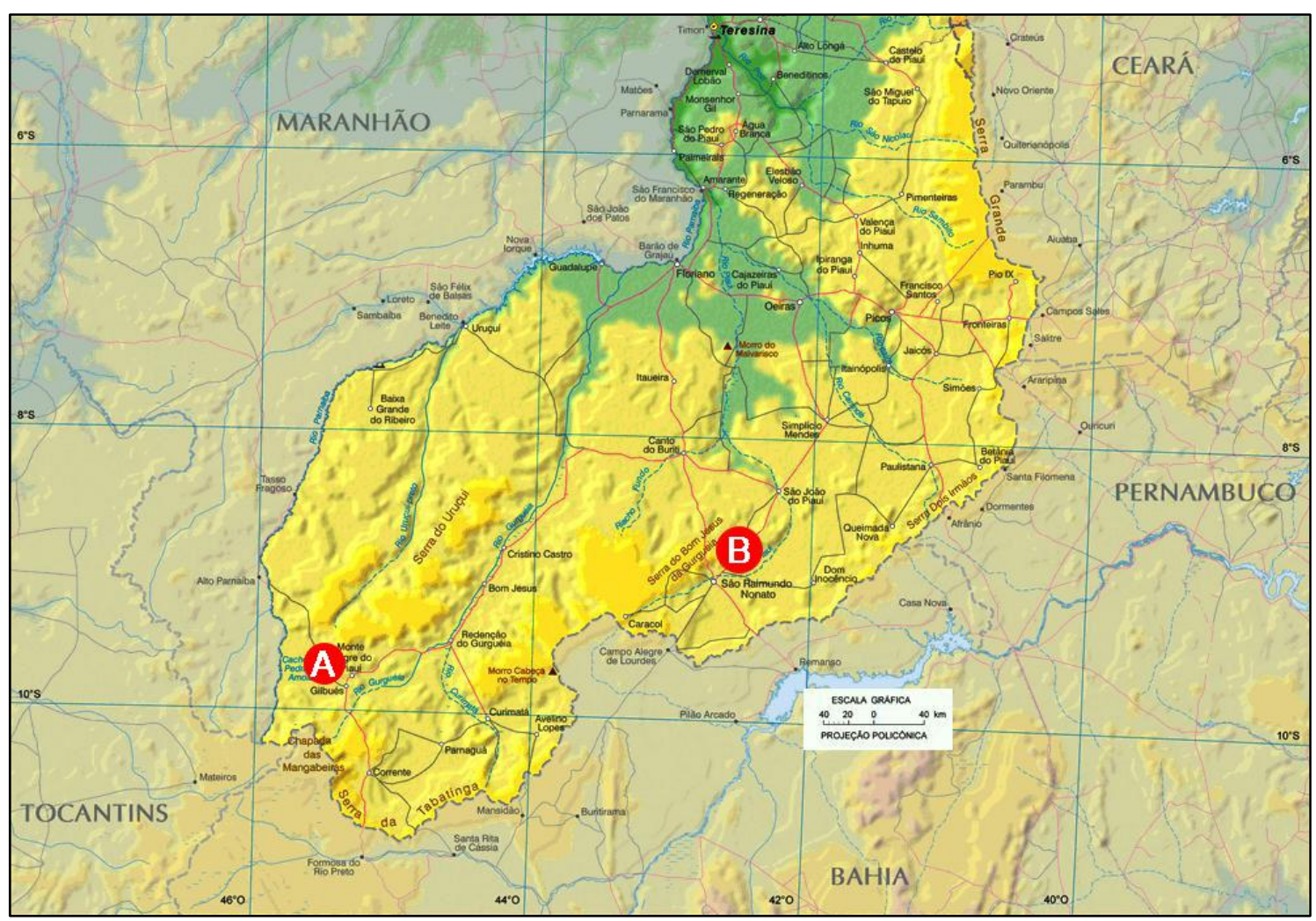

Figura 23. Localização da Fazenda Boa Vista (A) e do Parque Nacional da Serra da Capivara (B), no Piauí.

A Fazenda Boa Vista (9050' S / 4521' W; Figura 23 A) é de propriedade privada, numa região de ecótono cerrado/caatinga, nas proximidades da cidade de Gilbués (PI). Excetuando-se a família Oliveira, que reside no local, as habitações humanas mais próximas encontram-se a muitos quilômetros de distância. O terreno é basicamente inalterado, sem estradas asfaltadas por muitos quilômetros, em todas as direções.

O relevo é caracterizado por uma planície limitada por escarpas e "mesas" de arenito que se erguem até mais de 30m de altura, com abundantes blocos de arenito aos pés das escarpas. As planícies são constituídas, em sua maior parte, por chapadas (com predomínio de árvores de médio porte,

42 A "homepage" do Projeto EthoCebus pode ser acessada no endereço: http://www.ip.usp.br/docentes/ebottoni/EthoCebus/echome.html 
palmeiras rasteiras e forrageiras exóticas) e brejos (com árvores de médio porte formando matas ciliares, buritizais e a presença de pequenas lagoas e cursos d'água). Nas encostas dos morros de arenito, a vegetação é arbustiva e de árvores de pequeno e médio porte, com baixa densidade de palmeiras. Já os topos dos morros são caracterizados por vegetação herbácea e arbustiva e algumas espécies de bromeliáceas e cactáceas.

Há uma clara sazonalidade no regime de chuvas, com uma estação seca (de maio a setembro, com precipitação média de $10 \mathrm{~mm}$ ), quando a água provavelmente constitui um recurso limitante, e uma estação chuvosa (de outubro a abril, com precipitação média de $155 \mathrm{~mm}$ ).

\subsubsection{A quebra de cocos por macacos-prego selvagens}

Desde a primeira expedição Fragaszy et al (2004), realizada por Fragaszy, Visalberghi e Patrícia Izar (com o apoio de M. Oliveira), ficou evidente que a quebra de cocos com o auxílio de pedras era uma atividade rotineira desta população de macacos-prego (C. libidinosus), conforme atestavam os numerosos sítios de quebra localizados, repletos de restos de cocos e marcas de uso nas "bigornas" de arenito (que é bastante friável nesta região).

Os cocos consumidos variam muito em dureza e tamanho, dos pequenos cocos Astrocaryum (com 2.5 a $3 \mathrm{~cm}$ de diâmetro) aos de Attalea (ovais, com cerca de $5 \times 6 \mathrm{~cm}$ ) e pareciam constituir um recurso bastante importante, especialmente na estação seca. Foi realizado um levantamento da abundância de palmeiras ao longo de um transecto de $1.2 \mathrm{~km}$, contando o número de palmeiras visíveis e a distância de avistamento a cada 50 m (24 amostras). A densidade estimada foi de 86 palmeiras/hectare, considerando a distância média de avistamento, e de 159 palmeiras/hectare, considerando a distância máxima de avistamento. As espécies de palmeiras desta área tem caules subterrâneos curtos e as frondes e os cachos de frutos emergem do solo.

Os "martelos" utilizados na quebra dos cocos e outros alimentos encapsulados, geralmente seixos de quartzo, podem pesar mais de $1 \mathrm{~kg}$ (algo notável para animais pesando menos que $4 \mathrm{~kg}$ ) e são relativamente escassos na região (ao contrário do que acontece na Serra da Capivara - v. adiante), o 
que implica em seu transporte por grandes distâncias, ao menos no estabelecimento de um novo sítio de quebra.

Neste primeiro estudo, foi observado um grupo de macacos (Grupo do Chicão - o mesmo grupo fotografado por Oxford) já habituado e atraído pelo aprovisionamento para as proximidades de um esconderijo de observação (Figura 24), e realizado um levantamento dos sítios de quebra em sua área de uso.

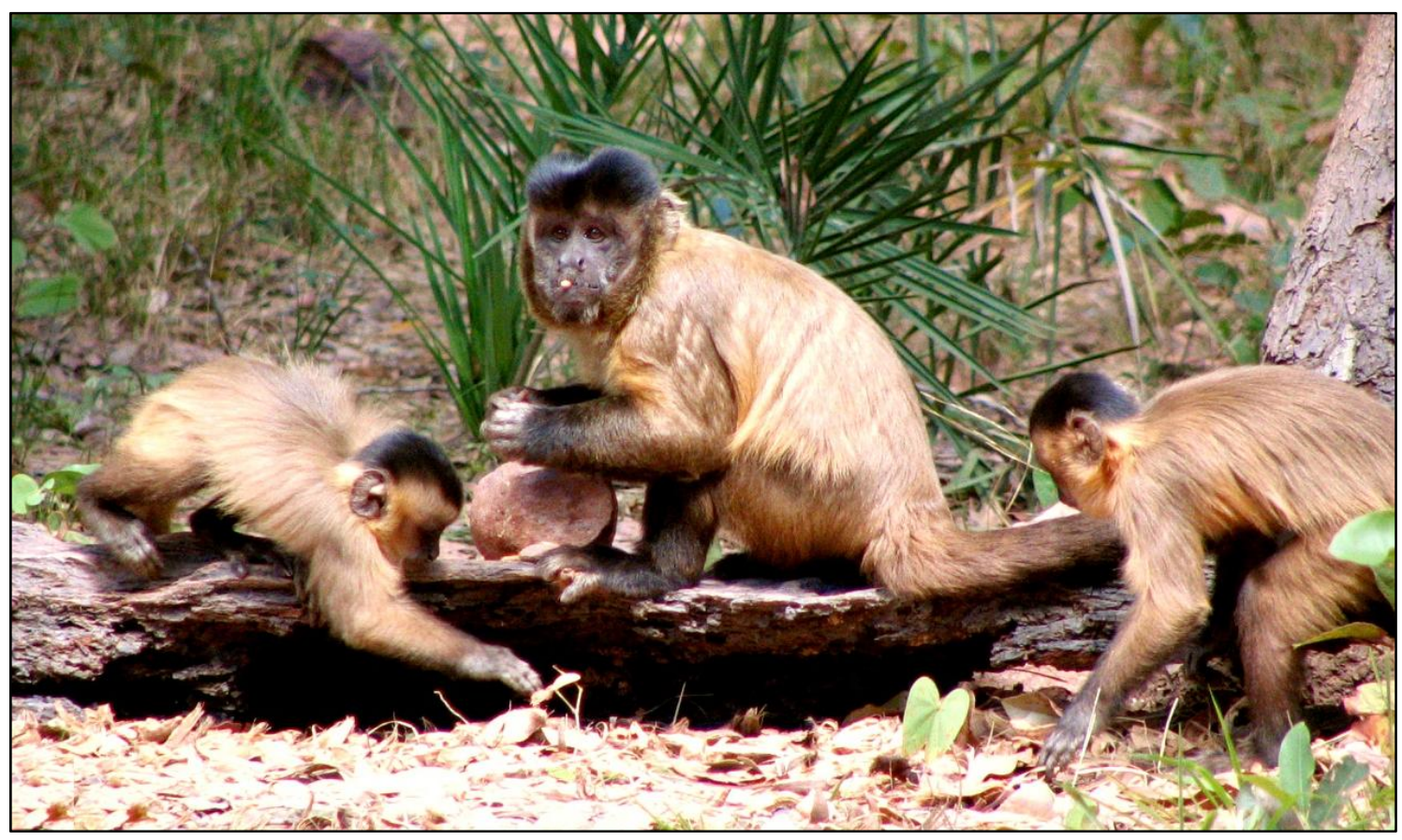

Figura 24. Chicão (macho dominante) e "scroungers" (Fazenda Boa Vista) (foto T. Falótico).

Uma descrição mais detalhada das ferramentas nos sítios de quebra pode ser encontrada em Visalberghi et al (2007) - e uma caracterização das propriedades físicas das quatro espécies de cocos mais freqüentemente consumidas - tucum (Astrocaryum campestre), catulé (Attalea barreirensis), piaçava (Orbignya sp) e catulí (Attalea sp) - está disponível em Visalberghi et al (2008). De um modo geral, a resistência dos frutos está diretamente correlacionada ao seu tamanho (que geralmente também se correlaciona com a espessura da casca da semente) e a complexidade estrutural (partições internas). Para os cocos de piaçava, os mais duros analisados neste estudo, foi verificada uma resistência à quebra ("peak-force-at-failure") comparável à dos cocos "panda" quebrados por chimpanzés selvagens. 
As posturas dos animais na quebra de cocos eram similares às observadas entre os macacos do PET: uma postura mais "sentada", com os "martelo" seguro em ambas as mãos, e outra mais ereta, em que o macaco podia chegar a saltar durante a fase ascendente do movimento do martelo, mantendo a cauda apoiada contra o solo (Figura 25).

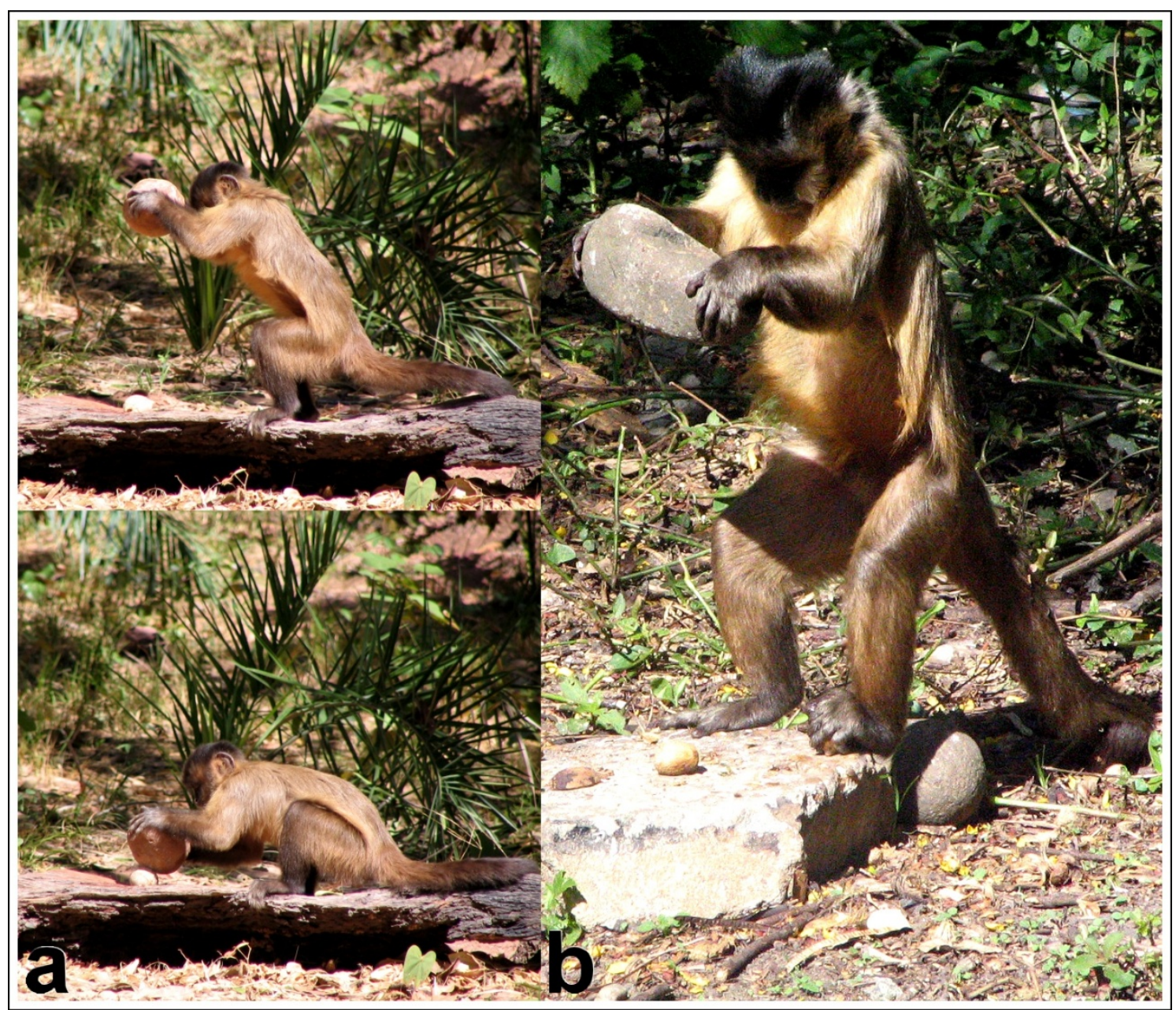

Figura 25. Variantes posturais na quebra de cocos (a, Fazenda Boa Vista; b, PET) (fotos T. Falótico).

Liu et al (2009) examinaram em maior detalhe a biomecânica da quebra de cocos, mostrando que os padrões motores empregados pelos macacos tendem a maximizar o desempenho minimizando os riscos de lesões, de formas comparáveis a humanos halterofilistas. Com alguma variabilidade individual, na fase ascendente do movimento, o "martelo" é erguido o mais alto possível e, na fase descendente, os macacos aplicam energia adicional à pedra, com ajustes posturais que parecem conferir maior precisão ao golpe. Os 
macacos-prego usam pedras proporcionalmente maiores que as empregadas por chimpanzés e atingem maiores velocidades na fase descendente do movimento. A postura bípede durante a quebra talvez indique que se trate de uma atividade mais extenuante para os macacos-prego que para os chimpanzés, o que levanta várias questões interessantes quanto ao ganho energético e quanto à importância estratégica do uso destes recursos para os macacos-prego nestes ambientes.

\subsubsection{Distribuição de recursos e transporte de ferramentas}

Um censo realizado através de transectos demonstrou quantitativamente (Visalberghi et al 2009b) que, embora as palmeiras e as superfícies duras e planas o suficiente para constituírem "bigornas" sejam relativamente abundantes, os "martelos" potenciais são escassos na região. Entre junho de 2006 e maio de 2007, meu orientando Eduardo Darvin Ramos-da-Silva e Noemi Spagnoletti monitoraram, respectivamente, um grupo não-provisionado (grupo do Zangado) e o grupo do Chicão. Ao longo de $1709 \mathrm{~h}$ de observação direta, foram registrados 1624 episódios de quebra de frutos encapsulados. Os macacos transportaram estes itens alimentares ( $N=288)$, "martelos" ( $N=26)$ ou ambos ( $\mathrm{N}=33)$ até as "bigornas". Os "martelos" eram em geral pedras ( $N=55)$, mas em quatro casos, cocos de piaçava ou catulé foram usados para quebrar cocos de tucum. Os frutos encapsulados foram transportados por uma distância média de $16 \mathrm{~m}$ (machos adultos) e de $10 \mathrm{~m}$ (fêmeas adultas e juvenis).

Dos 22 macacos observados quebrando cocos, 12 transportaram seus "martelos" (4 machos adultos, 4 fêmeas adultas e 4 juvenis). Os "martelos" foram transportados por uma distância média de 3m (na quebra de cocos) ou de $5.5 \mathrm{~m}$ (outros alimentos encapsulados). As distância máximas de transporte foram, nas diferentes faixas de sexo/idade, de $21 \mathrm{~m}$ (machos adultos), $8 \mathrm{~m}$ (fêmeas adultas) e 12m (juvenis). De modo geral, os adultos transportaram pedras maiores que os juvenis. Naturalmente, uma vez estabelecidos os sítios de quebra, o transporte de "martelos" não constitui uma atividade necessária em todos os episódios de quebra. Em muitos destes eventos de transporte, a "bigorna" não se encontrava imediatamente à vista do sujeito, o que levanta 
questões interessantes sobre a capacidade de planejamento dos macacosprego.

\subsubsection{Planejamento na escolha de ferramentas?}

Ao quebrar cocos $(\mathrm{N}=77)$, os machos transportaram pedras adequadamente duras, tais como seixos de quartzo, em 15 ocasiões - e pedras mais moles (como pedaços de arenito), inadequadas, em 4 casos; as fêmeas transportaram pedras duras nas 5 ocasiões observadas, enquanto que os juvenis transportaram pedras inadequadas em 7 dentre 5 episódios. Por outro lado, para quebrar itens encapsulados mais moles que os cocos $(N=8)$, os adultos transportaram pedras mais moles em 4 dentre 5 casos, e os juvenis, em 1 de 2 episódios. Estes "martelos" foram transportados até "bigornas" de pedra $(\mathrm{N}=41)$ ou de madeira $(\mathrm{N}=18)$. Em função destas observações naturalísticas, a escolha de "martelos" adequados foi subseqüentemente examinada numa série de experimentos de campo no local (v. adiante, Capítulo 6).

\subsection{Primeiro estudo na Serra da Capivara}

À época da publicação das fotos feitas por Peter Oxford na Fazenda Boa Vista, Massimo Mannu realizava suas primeiras visitas de reconhecimento ao Parque Nacional da Serra da Capivara (PNSC), por indicação de Antonio Moura, que ali havia observado episódios de uso de ferramentas (observações mais tarde publicadas em Moura \& Lee 2004). Conforme viemos a constatar, as populações desta área exibem um "tool-kit" maior que o costumeiro, utilizando varetas como sondas e pedras para vários propósitos.

\subsubsection{Local de estudo e amostragem}

O PNSC, localizado nas proximidades de São Raimundo Nonato (PI, 08²7' -

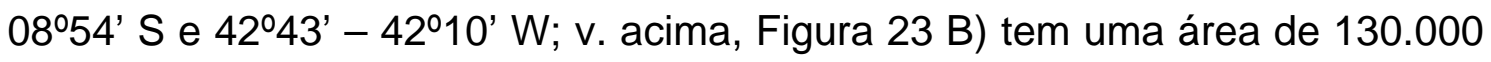
ha e um perímetro de 214 km, com vegetação de caatinga (Figura 26). O clima 
é caracterizado como semi-árido, de grande variação sazonal, com temperaturas de 10 a $47^{\circ} \mathrm{C}$. A temperatura média anual é de $28^{\circ} \mathrm{C}$, e a precipitação anual média, de 689mm (Araújo et al 1998).

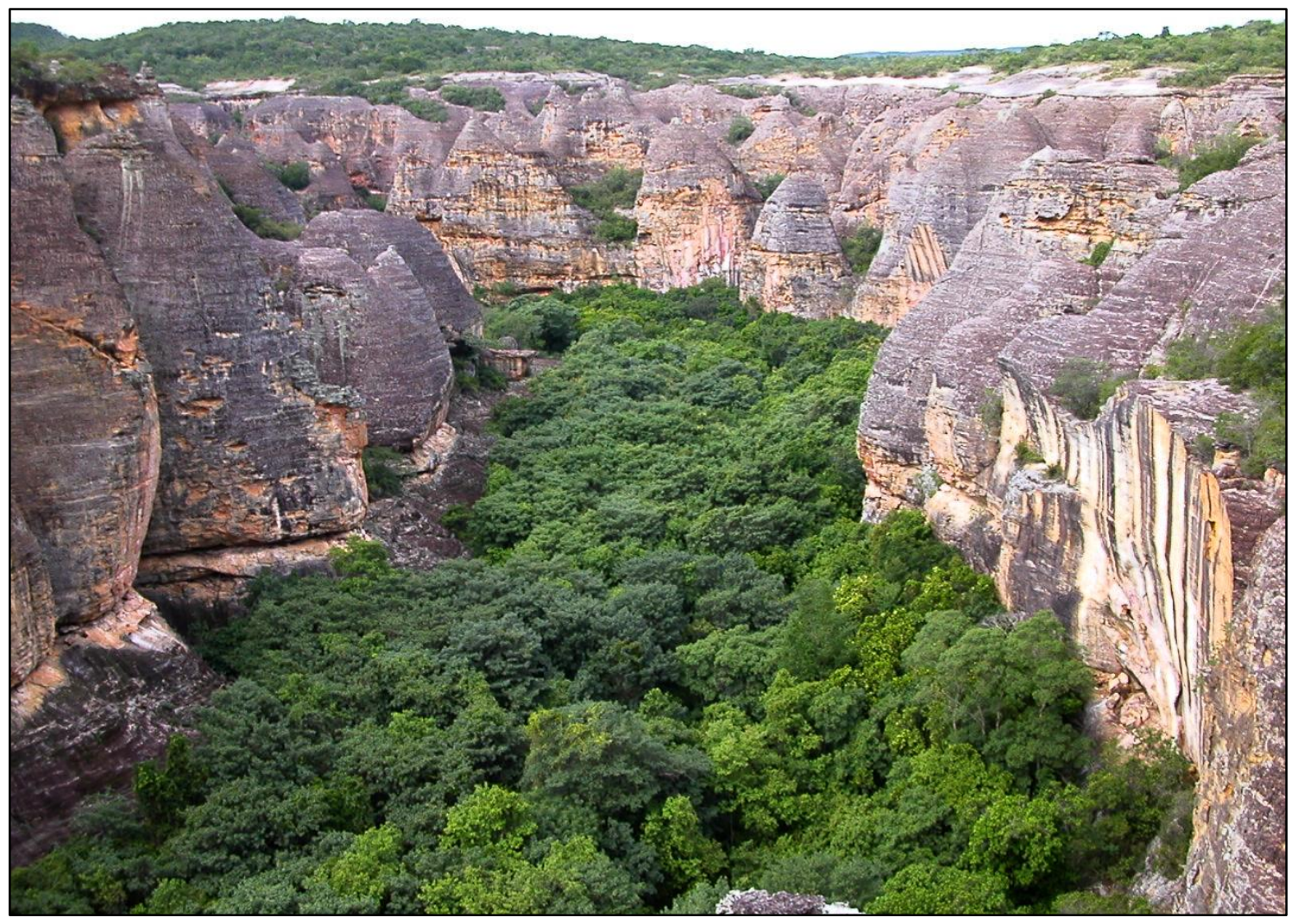

Figura 26. Boqueirão visto do alto da Serra da Capivara (foto E.B. Ottoni).

Dois grupos de C. libidinosus, compostos, em maio de 2005, por 52 e 12 indivíduos, foram acompanhados. Estes grupos eram parcialmente simpátricos, com os centros de suas áreas de uso distando $4 \mathrm{~km}$ entre si. O maior deles, o grupo da Jurubeba, era composto apenas de indivíduos selvagens. Embora se trate de um grupo bastante grande para os padrões dos macacos-prego (Fragaszy, Visalberghi \& Fedigan 2004), há outros grupos de tamanho semelhante na região (como o grupo da Pedra Furada, que seria mais tarde estudado por T, Falótico [v. adiante], que chegou a ter 47 indivíduos). O grupo menor (Grupo dos Oitenta) era formado por três animais cativos soltos no parque (duas fêmeas adultas e um macho juvenil) aos quais se juntaram animais selvagens, provavelmente emigrantes do grupo da Jurubeba (Moura \& Lee 2004). Ambos os grupos eram aprovisionados (com banana, abóbora, milho ou mandioca), mas, durante nossa coleta de dados, o aprovisionamento 
se restringiu à estação seca (de maio a outubro). Ocasionalmente, os dois grupos se juntavam e assim permaneciam por vários dias (30.4\% do tempo de observação).

Entre março de 2004 e maio de 2005, Massimo Mannu monitorou estes dois grupos, totalizando 701.5 horas de contato visual ${ }^{43}$. Todos os episódios observados de uso de ferramentas foram registrados (amostragem de "Todas as Ocorrências") com o auxílio de câmera de vídeo e/ou gravador de áudio. Devido à baixa visibilidade e grande dificuldade de acompanhamento contínuo dos animais no terreno irregular da Serra da Capivara, optamos por desistir das amostragens pelo método do Animal Focal.

O uso das ferramentas de pedra foi descrito em função tanto das características motoras/posturais quanto dos efeitos sobre os objetos-alvo, como semelhante ao de "martelos", de "enxadas" ou de "machados". As varetas utilizadas como sondas eram freqüentemente modificadas antes de seu uso e foram classificadas, quando essa preparação pode ser observada, de acordo com o número de passos empregados na sua produção ( $v$ adiante, Tabela 1).

\subsubsection{Resultados gerais}

Foram registrados 677 episódios de uso de ferramentas (0.97 episódio/hora de observação, envolvendo sujeitos de ambos os grupos), com uma duração total de $14.6 \mathrm{~h}$ (2.1\% do tempo de contato visual). 517 destes episódios envolveram o uso de pedras e 160, o uso de partes vegetais (em geral, galhos). A utilização de ferramentas foi mais freqüente na estação seca, e negativamente correlacionada com a disponibilidade de insetos ${ }^{44}$.

Não foram notadas diferenças entre as taxas de uso de ferramentas dos dois grupos, nem entre os animais selvagens e os 3 ex-cativos. As duas

\footnotetext{
${ }^{43}$ A coleta de dados se estendeu até novembro 2006 (até março de 2006, por Massimo Mannu e pelo assistente de campo; de março a novembro, apenas por este último, Francisco Reinaldo), porém os dados posteriores a maio de 2005 não haviam ainda sido transcritos ou analisados por ocasião do falecimento de Massimo Mannu, que trabalhava, então, na elaboração de sua Tese de Doutoramento. Os resultados parciais reproduzidos neste capítulo foram publicados postumamente em Mannu \& Ottoni (2009).

${ }^{44}$ Medida pelo peso seco mensal de insetos recolhidos nas armadilhas pitfall.
} 
fêmeas ex-cativas eram usuárias infreqüentes de ferramentas, o que era esperado, dadas as diferenças de gênero nestes comportamentos verificadas em outras populações de C. libidinosus (Fragaszy, Visalberghi \& Fedigan 2004), bem como nas populações semi-livres de C. nigritus ou híbridos (Ottoni \& Mannu 2001, Rocha, Reis e Sekiama 1998), onde machos adultos e juvenis costumam usar ferramentas com mais freqüência que as fêmeas para quebrar $\operatorname{cocos}^{45}$. Devido ao tempo que os grupos passaram juntos, e dadas as dificuldades de reconhecimento individual de infantes e juvenis no início da coleta de dados, os episódios de uso de ferramentas por indivíduos de ambos os grupos foram analisados conjuntamente.

\subsubsection{Pedras como ferramentas para quebrar, cavar e cortar}

A maioria dos episódios de uso de ferramentas envolveu o uso de pedras como "martelos" - em geral, para abrir frutos encapsulados ou sementes, ou para amolecer o solo para a escavação. Às vezes, porém, pedras podiam ser também utilizadas para cortar partes de vegetais ou como "enxadas" ao cavar e, em uma ocasião, uma pedra foi usada para espalhar as folhas no chão, provavelmente em busca de artrópodes.

Foram registrados 182 episódios em que pedras foram usadas para quebrar, abrir, cortar ou esmagar objetos ou superfícies (.26 episódios/hora de observação). Mais da metade destes episódios envolveu a abertura de frutos encapsulados ou sementes $(\mathrm{N}=100)$. Os principais itens processados deste modo eram frutos de jatobá (Hymenaea courbaril, $\mathrm{N}=87$; Figura 27). Os "martelos" também eram usados para quebrar madeira morta, conglomerado de arenito ou cimento (das margens de reservatórios artificiais) ou para destacar galhos ou a casca de árvores (supostamente em busca de invertebrados ou outros itens comestíveis), ou ainda para esmagar caules, raízes, tubérculos, cactos e itens alimentares aprovisionados (milho, mandioca, abóbora), para deslocar pedras maiores e/ou para esmagar invertebrados (artrópodes ou caracóis) encontrados embaixo delas.

\footnotetext{
${ }^{45}$ Embora, como já mencionado, estas diferenças diminuam quando se trata de sementes menos duras (Ramos-da-Silva 2008) ou em circunstâncias especialmente favoráveis, como no caso do PET (Coelho 2008).
} 


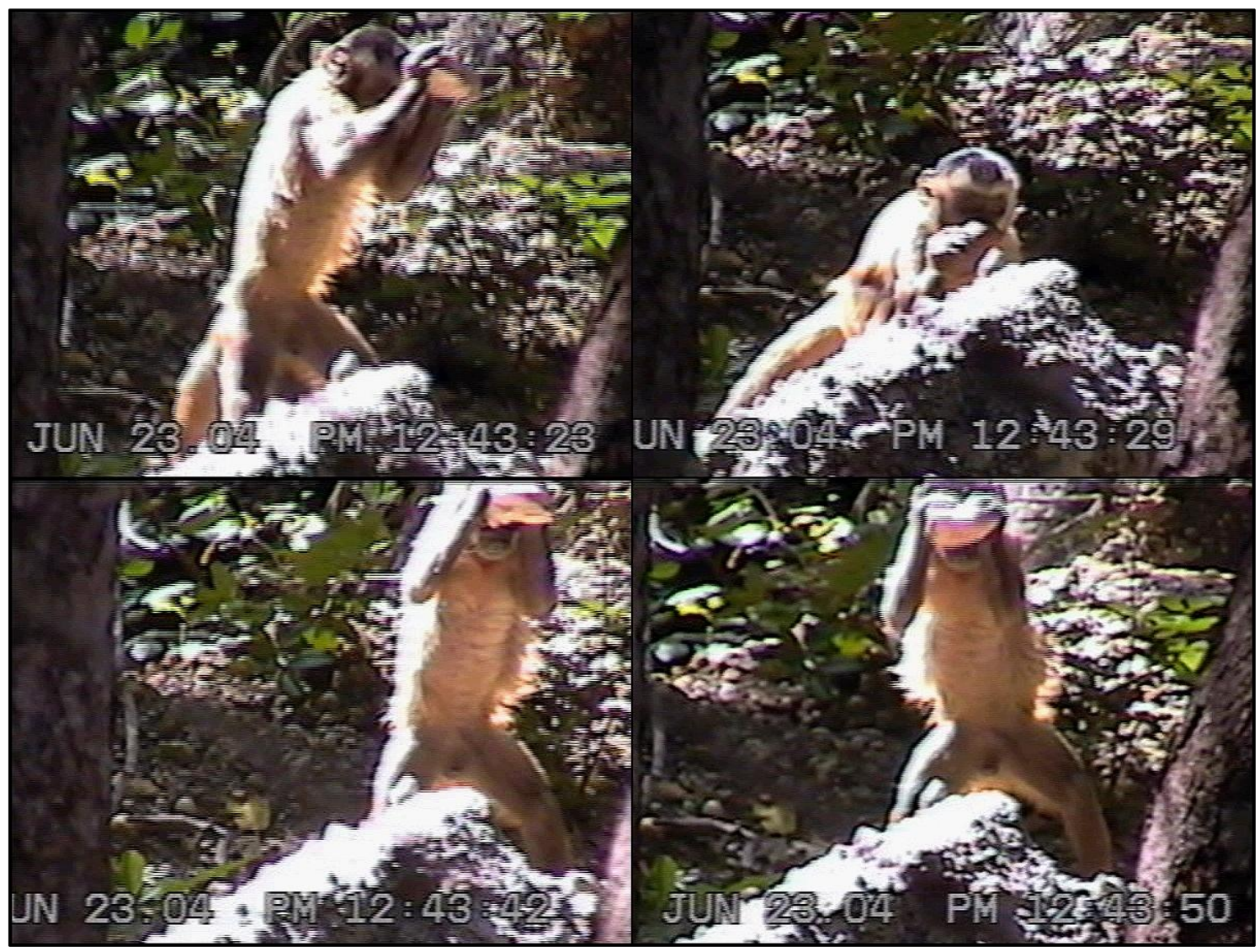

Figura 27. Quebra de frutos de jatobá, Hymenaea courbaril (vídeo M. Mannu).

Em alguns casos $(\mathrm{N}=6)$, os macacos golpearam pedras chatas perpendicularmente, como "machadinhas" (de modo similar, no que se refere à postura corporal, ao "martelar") contra galhos secos, cactos (Opuntia sp) ou tubérculos, cortando-os, ao invés de esmagá-los. Três juvenis (um macho, uma fêmea e um indivíduo não-identificado) foram observados cortando galhos mortos, um macho subadulto, cortando um tubérculo, e um macho adulto, um cacto.

Em 250 episódios, os animais usaram pedras como "martelos" para amolecer o solo e desenterrar raízes, tubérculos (Figura 28) ou ninhos de insetos (0.36 episódios/hora de observação), tendo sido observada a aquisição efetiva de comida em 21.6\% destes episódios. Os macacos, tipicamente, usavam as pedras como "pilões", erguendo-as com as mãos e golpeando contra o solo, largando-as e cavando com uma ou ambas as mãos ( $\mathrm{N}=125)$. Uma outra técnica envolvia bater com a pedra contra o solo com uma mão e ir 
removendo a terra solta com a outra $(\mathrm{N}=22)$. Ambas as técnicas foram combinadas em pelo menos 15 episódios (a técnica empregada não pode ser observada nos 88 episódios restantes). Em 12 destes episódios de escavação, as pedras foram também usadas como "enxadas" para puxar a terra solta para fora do buraco (Figura 29).

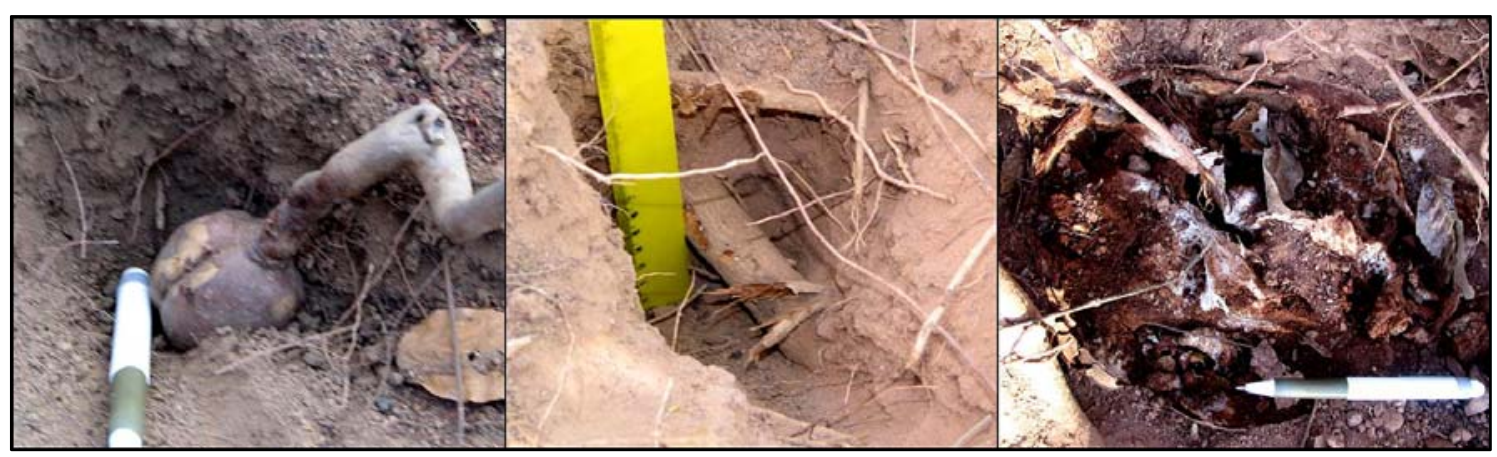

Figura 28. Buracos escavados com pedras para acessar raízes ou outros órgãos vegetais subterrâneos. Esquerda: tubérculo de Combretum cf. sp.; centro: raíz de aroeira (Astronium cf sp.); direita: tubérculo de batata-de-umbu (Spondias tuberosa) (fotos M. Mannu).

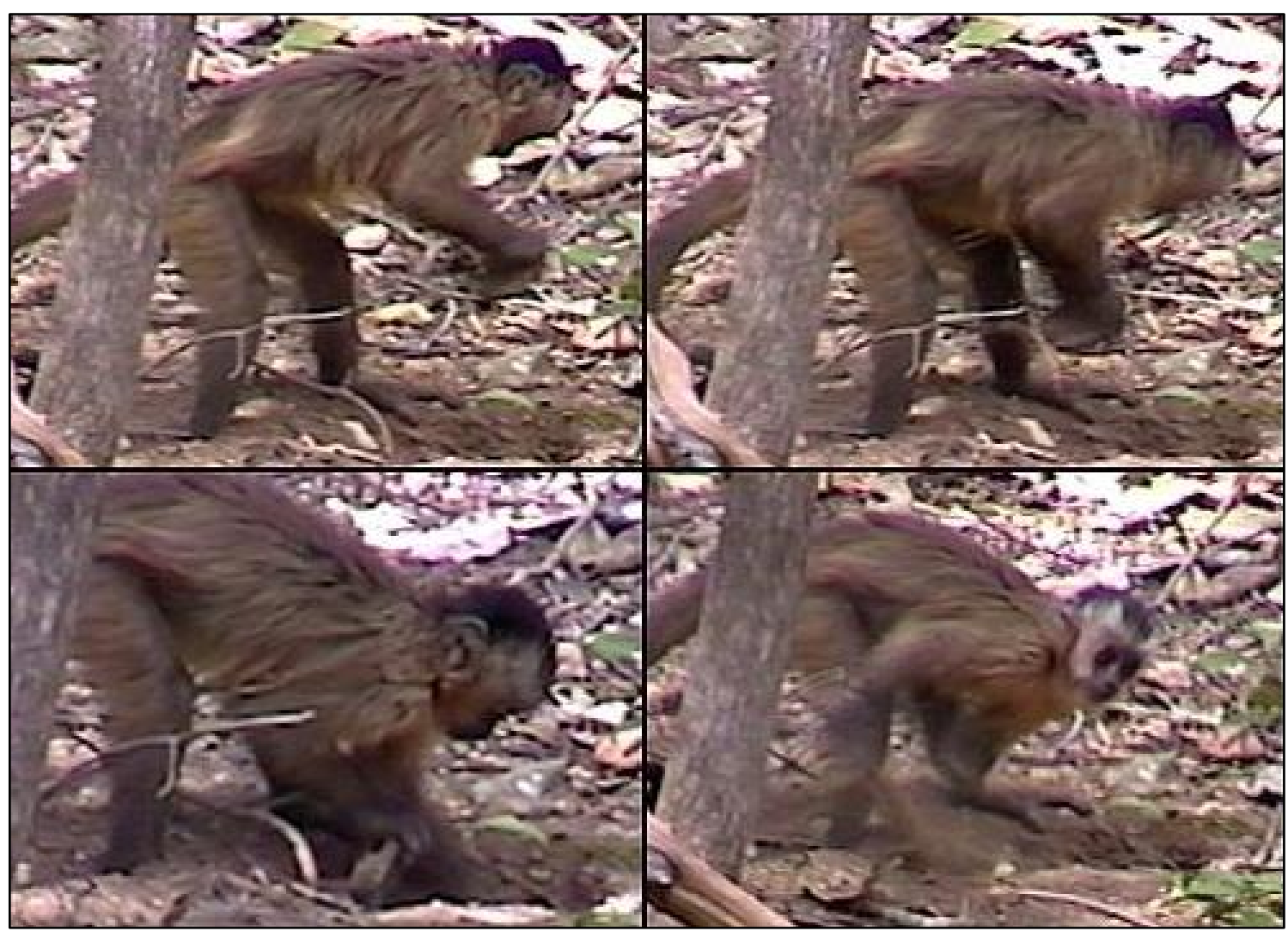

Figura 29. Escavação com o auxílio de pedras, usadas como “martelo” e como "enxada” (vídeo M. Mannu). 
É importante notar que, embora já houvesse relatos esparsos do consumo de órgãos vegetais subterrâneos de armazenamento por chimpanzés (Lanjow 2002), apenas recentemente foi registrado entre eles o uso de ferramentas (principalmente de madeira) para escavar estes recursos (Hernandez-Aguilar, Moore \& Pickering 2007).

Outro padrão comportamental bastante peculiar também envolve o uso de pedras como "martelos" ( $\mathrm{N}=84)$ : os macacos pulverizam seixos de quartzo presos ao conglomerado de arenito (Figura 30), lambendo, cheirando e/ou esfregando a face, o peito e as mãos com o pó assim produzido. O objetivo desta atividade permanece obscuro ${ }^{46}$. Em outros 75 eventos (não incluídos nestas análises), os macacos golpearam pedras contra seixos ou rocha conglomerada mas não tiveram sucesso em pulverizá-los ou deslocá-los devido à perda do "martelo".

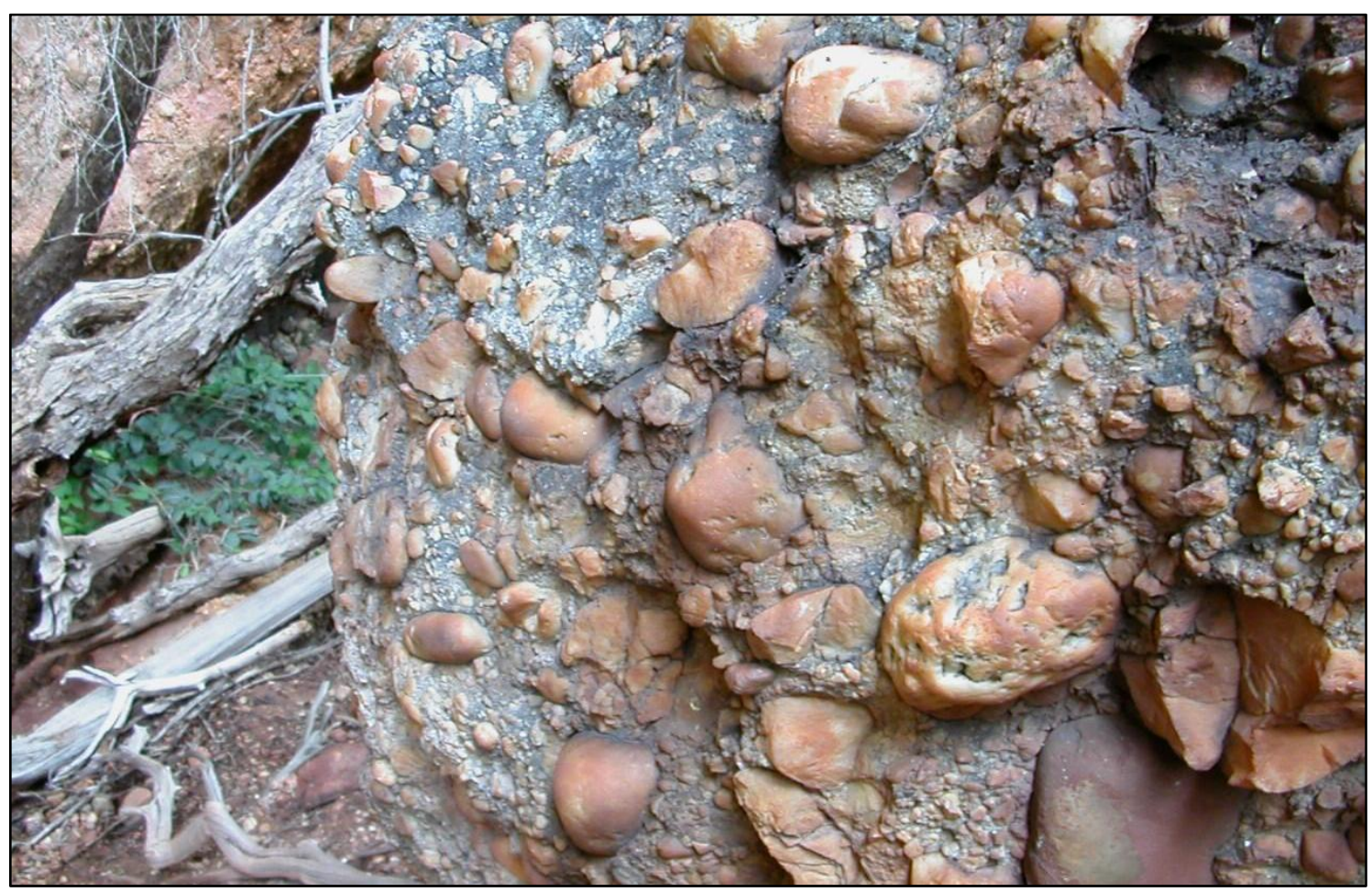

Figura 30. Conglomerado de rocha sedimentar com seixos de quartzo incrustados (foto E.B. Ottoni).

${ }^{46}$ Untar-se com uma variedade de substâncias, entretanto, é uma prática comum entre macacos-prego; em muitos casos, a finalidade é desconhecida, mas há casos melhor compreendidos, como o do "anting" (comportamento de esfregar formigas no corpo), que se mostrou uma técnica eficaz para repelir larvas de carrapato entre os animais do PET. 


\subsubsection{Varetas como ferramentas}

Partes de plantas foram usadas como sondas para explorar buracos de árvores (Figura 31), fendas nas rochas ou o espaço sob as cascas de árvores, em busca de abelhas ou outros artrópodes, mel ou cera (ou água, às vezes coletada nos reservatórios com este tipo de sonda) em 157 episódios (1-7 sondas usadas por episódio, com .22 episódios/hora de observação). Com poucas exceções, estas sondas eram varetas (235 em 238 sondas) obtidas de diversas espécies vegetais, como angico (Anadenanthera peregrina), feijãobravo (Capparis cynophallophora), jatobá (Peltogyne cf. confertiflora), catanduva (Piptadenia moniliformis), malva-da-serra (Vernonia sp), Tabebuia sp., uma Sapindaceae e oito espécies não-identificadas;Figura 32); as três sondas restantes foram dois pedaços de casca de árvore e uma espiga de milho. Cinco sondas foram reutilizadas 1 ou 2 vezes.

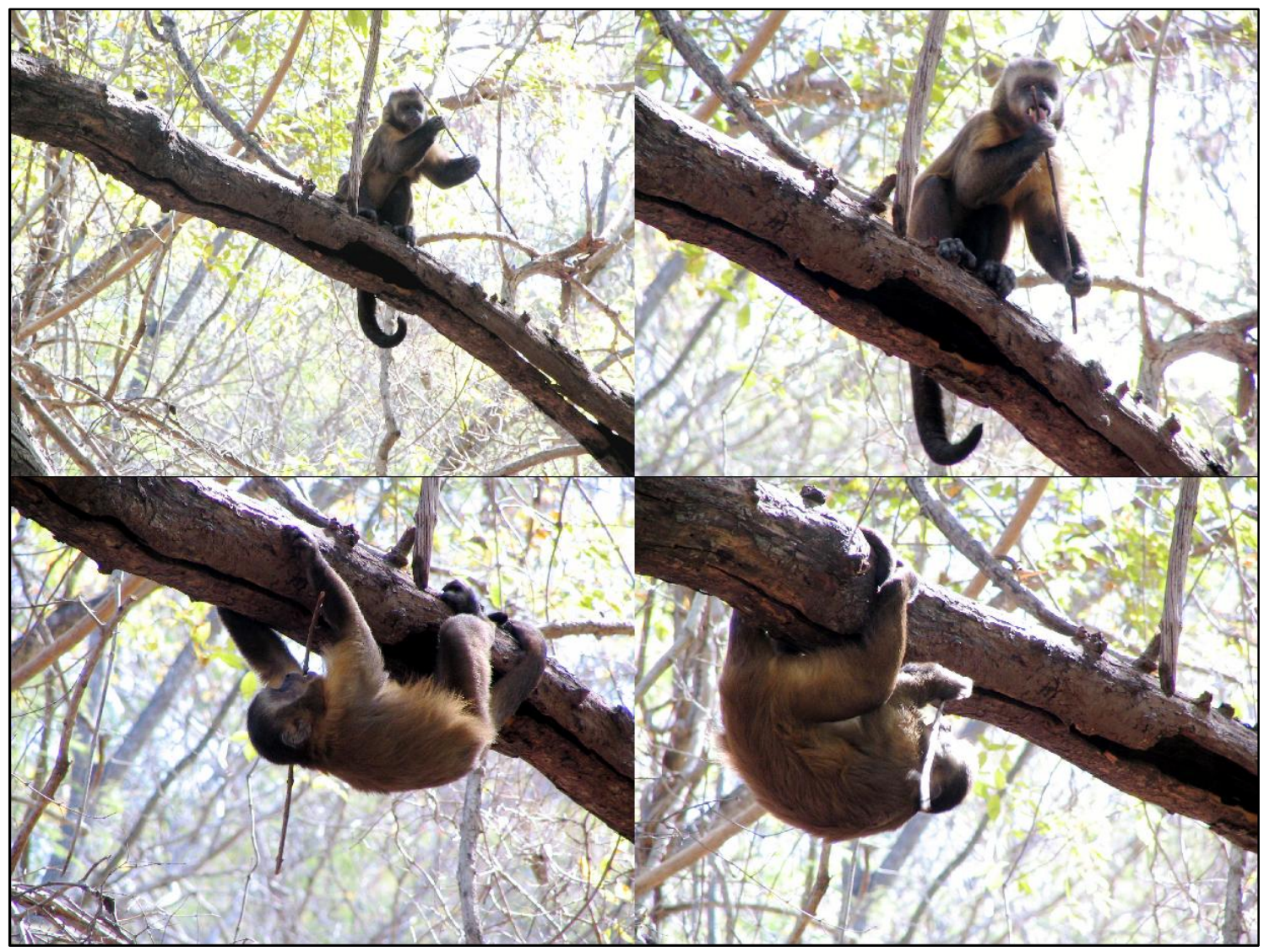

Figura 31. Uso de vareta como sonda por um macho subadulto (foto T. Falótico) 


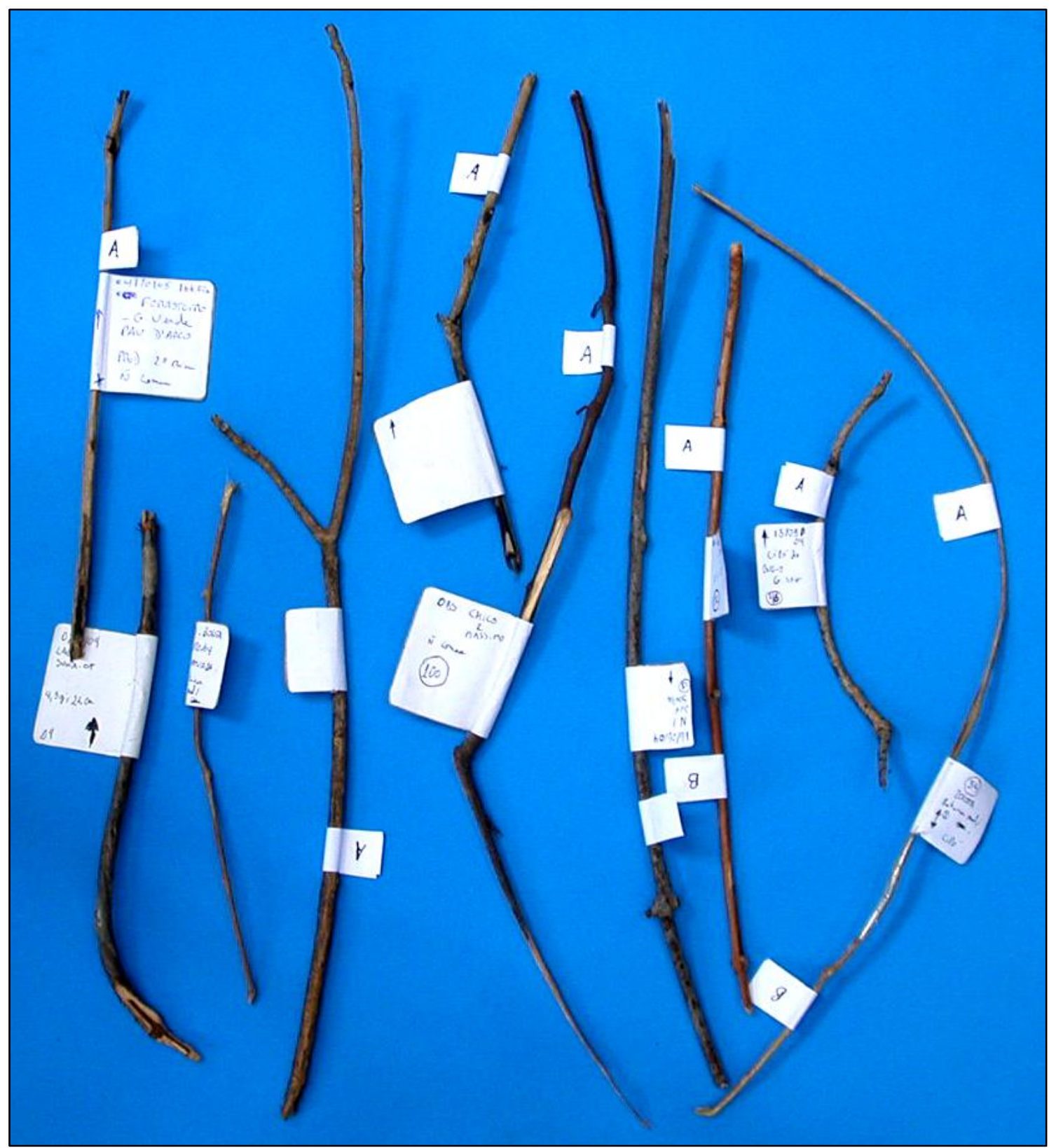

Figura 32. Exemplos de varetas usadas para acessar mel, cera, invertebrados ou água (foto E.B. Ottoni).

O uso de sondas era freqüentemente intercalado com o cheirar das pontas das ferramentas e/ou a manipulação das bordas dos buracos com os dedos ou a boca. Às vezes os macacos introduziam a sonda uma única vez, a retiravam de imediato, cheiravam a ponta introduzida e iam embora. Na maioria dos episódios, eles nada obtinham de dentro dos buracos ou fendas, mas tiveram sucesso em extrair mel, cera ou abelhas em $73.3 \%$ dos casos em que foi possível nos certificarmos de que o alvo era uma colméia (20 em 30 casos). Das 18 ocasiões em que havia a certeza de que os macacos estavam caçando 
insetos (que não abelhas) em buracos ou fendas, a presa conseguiu escapar em apenas um caso.

A produção da maioria destas sondas envolvia algum procedimento de modificação: o destacar de um galho com a(s) mão(s) e/ou a boca, o desbastar de folhas ou ramos laterais (costumeiramente era removida a extremidade distal com folhas) e/ou o afinamento da ponta. Para 63 dentre as 238 sondas coletadas, não foi possível registrar estes procedimentos preparatórios; as 175 sondas restantes foram classificadas, de acordo com o número de modificações, em quatro níveis de complexidade (Tabela 1). Apenas 13.7\% destas sondas foram usadas sem modificação, e a maioria (75.4\%) foi produzida (principalmente por adultos e subadultos) através de 1 ou 2 passos de modificação.

Tabela 1. Categorização das varetas utilizadas como sondas em função do número de modificações em sua produção (Mannu \& Ottoni 2009).

\begin{tabular}{|c|c|c|c|c|c|c|}
\hline 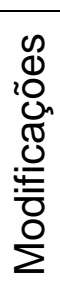 & Descrição & $\frac{\text { D }}{\frac{D}{\bar{C}}}$ & 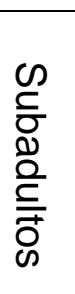 & 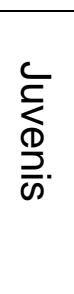 & 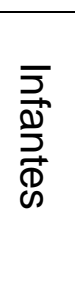 & Total \\
\hline 0 & Sem modificação & 4 & 9 & 11 & 0 & 24 \\
\hline 1 & $\begin{array}{l}\text { Destacar OU [Aparar OU Afinar } \\
\text { ponta (de uma vareta já solta)] }\end{array}$ & 32 & 11 & 19 & 1 & 63 \\
\hline 2 & Destacar E [Aparar OU Afinar ponta] & 42 & 12 & 15 & 0 & 69 \\
\hline \multirow[t]{2}{*}{3} & Destacar E Aparar E Afinar ponta & 9 & 8 & 2 & 0 & 19 \\
\hline & Total & 87 & 40 & 47 & 1 & 175 \\
\hline
\end{tabular}

As varetas eram às vezes $(\mathrm{N}=3)$ usadas ainda para golpear presas ou em exibições de ameaça (como relatado por Boinski 1988): em uma ocasião, os macacos do grupo de Oitenta encontraram um saruê (Didelphis albiventris) dentro de um buraco de árvore e, após alguns minutos de ameaças, dois juvenis (uma fêmea e um macho) usaram galhos para alcançá-lo, de duas maneiras: um com movimentos de "porrete", o outro com movimentos de "lança" (mas nenhum atingiu efetivamente o saruê). Em outro episódio, uma fêmea juvenil tentou, sem sucesso, usar um pedaço de madeira e um galho 
para esmagar um escorpião.

\subsubsection{Ferramentas com múltiplas funções}

Em três ocasiões, observamos uma pedra sendo sucessivamente reutilizada com diferentes funções: no primeiro caso, um macho adulto pulverizou um seixo de quartzo preso ao conglomerado com uma pedra, cheirou o pó produzido e, após transportar a pedra por três metros, a golpeou contra um tronco caído, puxando a casca solta e a inspecionando. No segundo caso, um macho juvenil usou uma pedra para cavar o solo, transportou-a por um metro e então golpeou com ela uma semente, que a seguir comeu. No terceiro evento de reutilização de ferramenta observado, uma fêmea juvenil usou uma mesma pedra em cinco episódios em seqüência: cavou o solo, soltou a casca de uma árvore caída (comendo um inseto no processo), pulverizou um seixo de quartzo (cheirando o pó), quebrou um cacto morto, comendo insetos de seu interior e, finalmente, golpeou a pedra contra o tronco de uma árvore viva de feijão-bravo. Esta pedra foi transportada, entre os episódios, por 4, 8, 1 e 2 metros (a seqüência completa durou cerca de 4 minutos).

\subsubsection{Uso seqüencial ou associado de duas ferramentas diferentes}

Duas ferramentas distintas foram utilizadas de maneira complementar ou seqüencial - na consecução de um único objetivo - em nove episódios observados. Em quatro casos, foram utilizados uma vareta e uma pedra, e nos cinco restantes, duas pedras.

Pedras e varetas combinadas: No primeiro evento (Figura 33), um macho subadulto (grupo da Jurubeba) bateu uma pedra contra a borda de um buraco num tronco podre e saltou para trás, com a saída de um mamangava do ninho; a seguir, o macaco passou a alternar golpes com a pedra contra as bordas do buraco e a introdução de um dedo; depois disso, tomou um galho fino do chão e o inseriu repetidas vezes no ninho de mamangava, tornou a golpear com a pedra sem remover a vareta, retirou-a do buraco para levá-la à boca, reintroduziu o dedo (que cheirou a seguir) e retomou a seqüência alternada de golpes de pedra e inspeções com os dedos. Um exame 
subseqüente do local mostrou que o buraco tinha sido alargado e o conteúdo do ninho de mamangava, acessado.

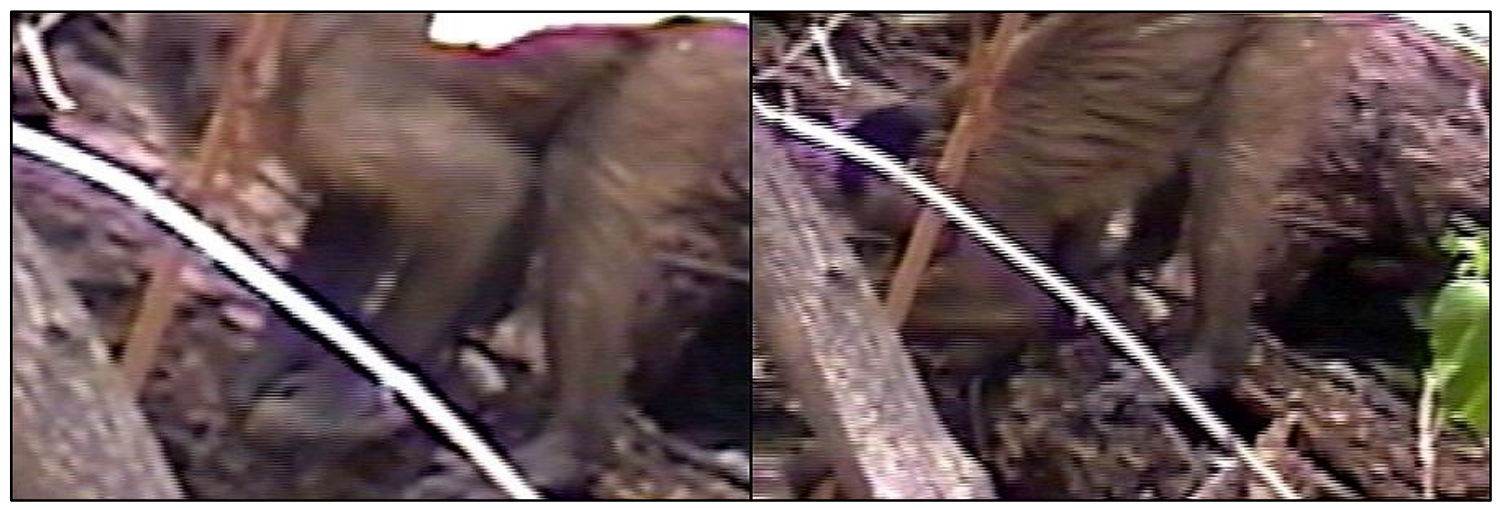

Figura 33. Uso seqüencial de uma pedra (para quebrar um tronco podre) e uma vareta (para um ninho de inseto no interior do tronco) (vídeo M. Mannu).

No segundo evento, o macho dominante do grupo dos Oitenta bateu uma pedra contra a borda de uma rachadura na rocha (conglomerado de arenito), removeu os cacos, desceu ao chão, arrancou um galho seco, retornou e introduziu a vareta na fenda, com movimentos vigorosos e repetidos. $\mathrm{O}$ alvo era, provavelmente, um lagarto ou um invertebrado (que o macaco não capturou).

No terceiro caso, um macho subadulto alargou uma rachadura na rocha conglomerada com o auxílio de uma pedra e a sondou com uma vareta. E no quarto, o macaco bateu uma pedra contra um tronco oco onde havia um ninho de abelhas, e a seguir usou uma vareta para sondar o buraco.

Duas pedras combinadas: Em duas ocasiões, um par de pedras foi utilizado para acessar um tubérculo: a primeira para escavá-lo, a segunda para quebrá-lo. Nas três observações restantes, os macacos usaram pedras pequenas para soltar seixos de quartzo maiores, incrustados no conglomerado de arenito - os quais foram por sua vez usados para golpear um tronco ou para pulverizar outros seixos incrustados. Num destes eventos de produção de pó de quartzo, um macho adulto que perdeu seu "martelo" enquanto lambia o pó bateu em alguns seixos incrustados com os dedos e se afastou. Depois de dois minutos, retornou de uma distância de dez metros, carregando uma pedra, e a golpeou contra um seixo incrustado, arrancando-o do conglomerado e o utilizando (após transportá-lo por dois metros) para golpear outro seixo 
incrustado (mas então, deixou o "martelo" cair e se afastou).

Os episódios de uso de pedras para soltar outras pedras (incrustadas na rocha conglomerada) para usá-las como ferramentas - constituem os primeiros casos registrados de uso espontâneo de ferramentas secundárias (Sugiyama $1987)^{47}$ por macacos do Novo Mundo. Do mesmo modo, o uso seqüencial ou associativo Sugiyama (op.cit.) de duas ferramentas numa única tarefa, bem como a modificação e o emprego de varetas como sondas foram, até o presente momento, observados exclusivamente nesta população de macacosprego.

\subsubsection{Observação do uso de ferramentas por coespecíficos}

Dos 642 episódios de uso de ferramentas em contextos de forrageamento contabilizados nos grupos da Jurubeba e dos Oitenta entre março de 2004 e maio de 2005 , em 54 deles (8.41\%) foi registrada a presença de pelo menos um observador coespecífico a até $2 \mathrm{~m}$ de distância.

Contrariando nossas previsões, os episódios de utilização de varetas foram proporcionalmente mais observados (12.67\%) que os de uso de pedras $(\mathrm{N}=492 ; \& .11 \%)\left(\chi^{2}=4.222 ; g . \mathrm{l} .=1 ; \mathrm{p}=0.043\right)$. $\mathrm{E}$ os usuários de varetas eram significativamente mais observados nos episódios em que a finalidade era extrair mel, cera ou insetos de ninhos de himenópteros do que quando a presa era outro tipo de invertebrado ou um pequeno vertebrado $\left(\chi^{2}=9.449\right.$; g.l. $=1$; $p=0.002)$, embora não houvesse diferença significativa entre estas classes de episódios quanto à duração. Foram, ainda, registrados 22 ocorrências de "scrounging" mediato de restos de ninhos por um observador ou outro indivíduo que chegou ao local após o termino do episódio.

\subsection{Continuidade da pesquisa na Serra da Capivara}

Os estudos na Serra da Capivara foram retomados em agosto de 2007, quando

\footnotetext{
${ }^{47}$ A quebra de frutos ou sementes com "martelos" e "bigornas" de pedra corresponde ao que Sugiyama (1997) chamou de ferramentas compostas.
} 
Tiago Falótico deu início à habituação de dois outros grupos de macacosprego, o grupo da Pedra Furada e o do Bocão, não-simpátricos com os grupos anteriormente estudados. O principal objetivo deste novo estudo foi o de verificar em que medida o "tool-kit" atipicamente complexo encontrado nos grupos da Jurubeba e dos Oitenta seria comum a outras populações da área, além de dar continuidade à busca de indicadores de vieses sociais na aprendizagem destes comportamentos que os caracterizem como tradições sociais.

A coleta de dados se encontra em fase de conclusão, mas os resultados preliminares já trouxeram respostas importantes para as primeiras questões levantadas pelo estudo anterior.

As observações, em função da nossa experiência prévia com as dificuldades do terreno, incluíram o uso de "Varreduras Instantâneas" e registros de "Todas as Ocorrências" de uso de ferramentas. Além do monitoramento da oferta de alimento por meio de armadilhas pitfall e coletores de frutos, as ferramentas utilizadas pelos macacos vêm sendo coletadas para uma mensuração mais precisa.

De dezembro de 2007 a fevereiro de 2008, as atividades foram interrompidas em função de uma epidemia viral não-determinada, que causou a morte de quase um terço do grupo, mas os trabalhos puderam ser retomados a seguir.

O grupo da Pedra Furada, que chegou a contar com 47 indivíduos, após a epidemia, outros desaparecimentos e alguns nascimentos, era composto, em maio de 2009, por 25 animais (2 machos adultos, 9 fêmeas adultas, 2 machos subadultos, 12 juvenis e 9 infantes).

O grupo do Bocão foi acompanhado de fevereiro de 2008 a março de 2009, quando, em função de dificuldades de acompanhamento, optamos por concentrar as observações no grupo da Pedra Furada. Durante a fase final de observação, este grupo contava com cerca de 28 indivíduos (6 machos adultos, 6 fêmeas adultas, 2 machos subadultos e cerca de 10 juvenis e 4 infantes). Durante as buscas e acompanhamento destes dois grupos, outros dois foram acompanhados esporadicamente. 


\subsubsection{Resultados preliminares}

A primeira constatação importante foi a de que o "tool-kit" do grupo da Jurubeba não era algo atípico: também entre estes novos grupos foi observado o uso diversificado de pedras para quebrar ou esmagar itens alimentares, para cavar e para pulverizar seixos de quartzo, e o uso de varetas como sondas. De modo geral, ambos os grupos (do Bocão e da Pedra Furada) exibem um repertório similar ao observado anteriormente nos grupos da Jurubeba e dos Oitenta - incluindo a curiosa "pulverização" de seixos.

Nos dois novos grupos foi observado o uso de pedras como "martelos" para esmagar ou quebrar alimento encapsulado, ou acessar itens dentro de troncos, de pedras para cavar o solo e extrair raízes, tubérculos ou aranhas (batendo para amolecer o solo e depois puxando a terra para fora com as mãos ou, às vezes, uma pedra), bem como o uso de pedras mais afiladas para cortar material vegetal, como "machados", o uso de varetas como sondas e o uso múltiplo e seqüencial de ferramentas (Falótico \& Ottoni 2008).

Por outro lado, um comportamento inédito de uso de ferramentas num contexto comunicativo foi registrado. Ao display típico de cio das fêmeas de macaco-prego seguindo um macho dominante, três fêmeas do grupo da Pedra Furada acrescentaram uma "técnica" que consiste em atirar pedras no macho dominante. Além da peculiaridade do contexto, é interessante notar que se trata das primeiras observações de lançamento direcionado de um projétil por macacos-prego selvagens (os deslocamentos de pedras às vezes associados a displays de ameaça não envolvem qualquer pontaria; o lançamento com pontaria foi induzido experimentalmente no cativeiro por Cleveland et al 2003).

Análises preliminares apontam para uma diferença significativa no peso dos "martelos" empregados por juvenis e adultos, mas não entre os "martelos" usados por machos ou fêmeas. E embora os machos tenham exibido mais episódios de uso de "martelos", a diferença não foi tão grande quanto em outros locais (68\%) e as fêmeas são tão eficientes quanto os machos - talvez porque os alimentos quebrados sejam menos duros, por exemplo, que os cocos da Fazenda Boa Vista: os macacos quebram principalmente castanhas de caju e frutos e sementes de grão-de-galo (Cordia rufescens, Figura 34; nesta área, diferentemente da ocupada pelos grupos da Jurubeba e dos 
Oitenta, não há jatobás).

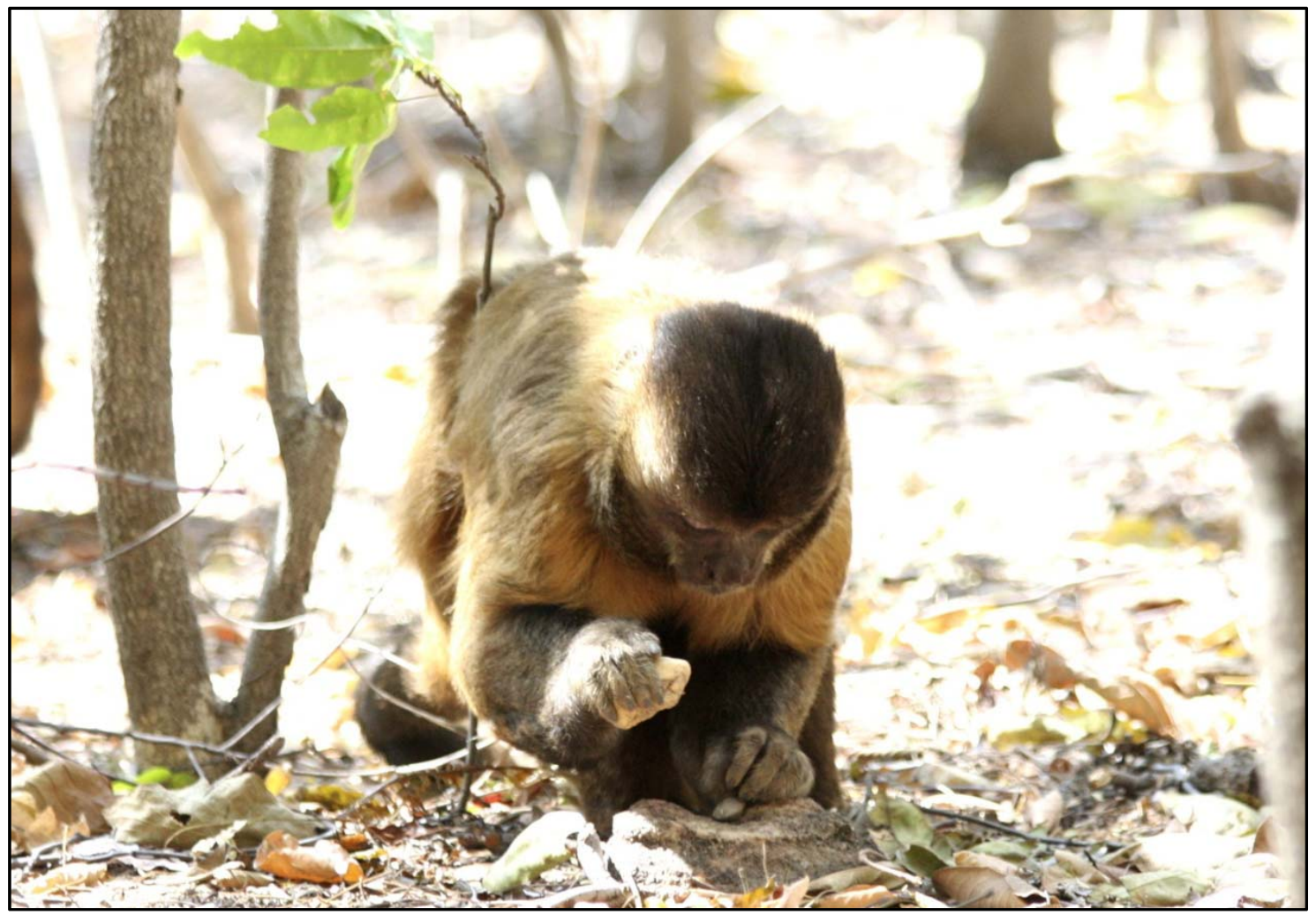

Figura 34. Macho adulto usando um "martelo" de pedra para quebrar uma semente de grão-de-galo (Cordia rufescens) (foto T. Falótico).

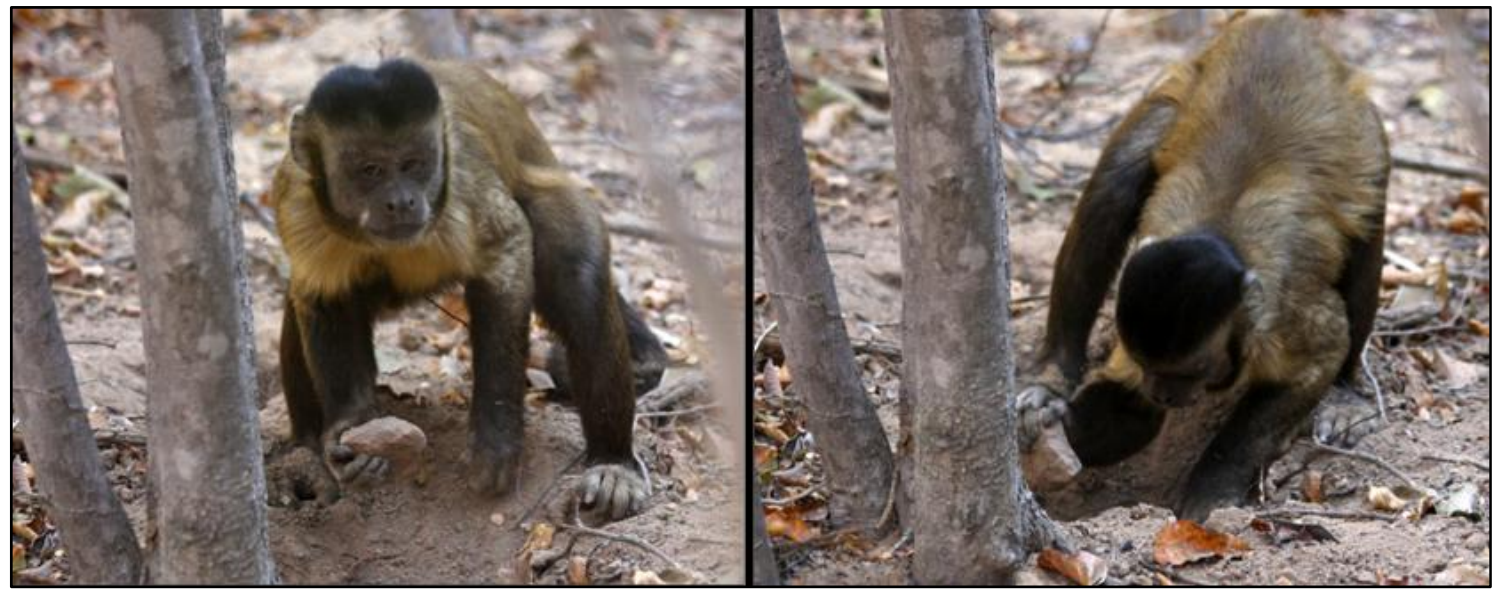

Figura 35. Macho subadulto do grupo do Bocão cavando com ferramenta de pedra (foto T. Falótico).

Mais da metade dos episódios de escavação foram executados por juvenis, mas os adultos e subadultos são mais eficientes (Figura 35). Também no caso das pedras para cavar, as usadas por adultos e subadultos são mais pesadas. Quando foi possível identificar o sexo, a maioria dos "escavadores" 
eram machos, que usaram ferramentas mais pesadas que as fêmeas.

As pedras para quebrar são significativamente mais pesadas que as para cavar.

As varetas mais longas são significativamente mais eficientes como sondas e, no seu uso, adultos e subadultos são mais eficientes que juvenis inclusive por usar varetas maiores - mas os juvenis executaram $68 \%$ dos episódios observados. Curiosamente - já que as diferenças entre os gêneros, no uso de pedras, parecem decorrer de diferenças na força física - o uso de varetas também foi uma atividade predominantemente de machos ${ }^{48}$.

\subsection{Diferentes "tool-kits", diferentes tradições?}

As diferenças constatadas até o momento entre os "tool-kits" destes grupos de C. libidinosus da Serra da Capivara e os de todas as outras populações da espécie estudadas até agora (por exemplo, na Fazenda Boa Vista; v. acima) ou dos outros macacos-prego usuários de ferramentas merecem ser investigadas em profundidade.

Há diferenças ambientais relevantes - digna de nota, em particular, a disponibilidade muito maior de seixos de quartzo na Serra da Capivara, em comparação com a verificada na Fazenda Boa Vista. Mas estas diferenças dificilmente dariam conta de toda a variação comportamental observada - por exemplo, no que se refere ao uso de varetas.

Considerando-se o que já sabemos graças aos estudos anteriores sobre o papel potencial da aprendizagem socialmente enviesada no desenvolvimento ontogenético do uso de ferramentas (Resende, Ottoni \& Fragaszy 2008; Ottoni, Resende \& Izar 2005), faz sentido supor que, por trás destas diferenças entre populações nos "tool-kits" e nos repertórios comportamentais associados ao uso de ferramentas, possivelmente estejam diferentes tradições comportamentais.

\footnotetext{
${ }^{48} 98 \%$ dos episódios em que foi possível identificar o sexo do sujeito.
} 



\section{Capítulo 6: Experimentos de campo}

Nossos estudos sobre o uso de ferramentas por macacos-prego começaram com os experimentos sobre uso de varetas como sondas (Perondi, Izar \& Ottoni 1995; v. Capítulo 1) com um grupo semi-cativo numa ilha do Parque Ecológico do Tietê - antes mesmo de tomarmos conhecimento do uso espontâneo de ferramentas por outros grupos. A seguir, realizamos os experimentos sobre aprendizagem observacional por sujeitos cativos (Resende \& Ottoni 2001) relatados no Capítulo 3.

Também no cativeiro (Parque Zoológico de Guarulhos), em um estudo sobre enriquecimento ambiental, oferecemos a macacos-prego a oportunidade de interagir com pedras e cocos, em comparação com objetos utilizados em outros estudos (uma "caixa de forrageamento" com serragem e larvas de besouros, e um "brinquedo" ["joelho" de PVC]; Boinski et al 1999). Através de observações focais, examinamos a interação dos sujeitos com os diferentes estímulos: o "kit" de quebra de cocos se mostrou o estímulo mais atraente, eliciando significativamente mais interações que o "brinquedo" (a caixa com tenébrios obteve índices intermediários; Mendonça-Furtado \& Ottoni 2005).

No caso do grupo da Área de Preservação do PET, evitamos por muito tempo intervir de qualquer maneira na quebra de cocos para evitar uma "contaminação" das observações naturalísticas. Nosso único estudo experimental, na fase inicial, foi uma replicação do experimento envolvendo o uso induzido de varetas como sondas, com resultados semelhantes aos do primeiro estudo. 


\subsection{Uso experimentalmente induzido de varetas como sondas}

Ao longo de 122 sessões experimentais de 1 hora, distribuídas num período de quase um ano e meio, os macacos foram habituados a consumir melado livremente disponível no local (Fase 1: 3 meses/14 sessões) e, a seguir, expostos a uma caixa de acrílico (afixada a uma plataforma em uma árvore; Figura 36), com furos na parte superior que permitiam o acesso de sondas para extrair o melado de seu interior. Inicialmente (Fase 2: 1 mês/8 sessões), a caixa era colocada no local sem a disponibilização de ferramentas, para verificar se os animais resolveriam o problema produzindo sondas espontaneamente - o que não aconteceu (nesta fase). Durante a Fase 3, com um ano de duração, varetas de madeira foram fornecidas na plataforma, ao lado da caixa em 77 sessões. Como nenhum animal havia utilizado as ferramentas até a $26^{\mathrm{a}}$ sessão desta Fase, em 2 blocos de 10 sessões algumas varetas foram deixadas já introduzidas nos orifícios.

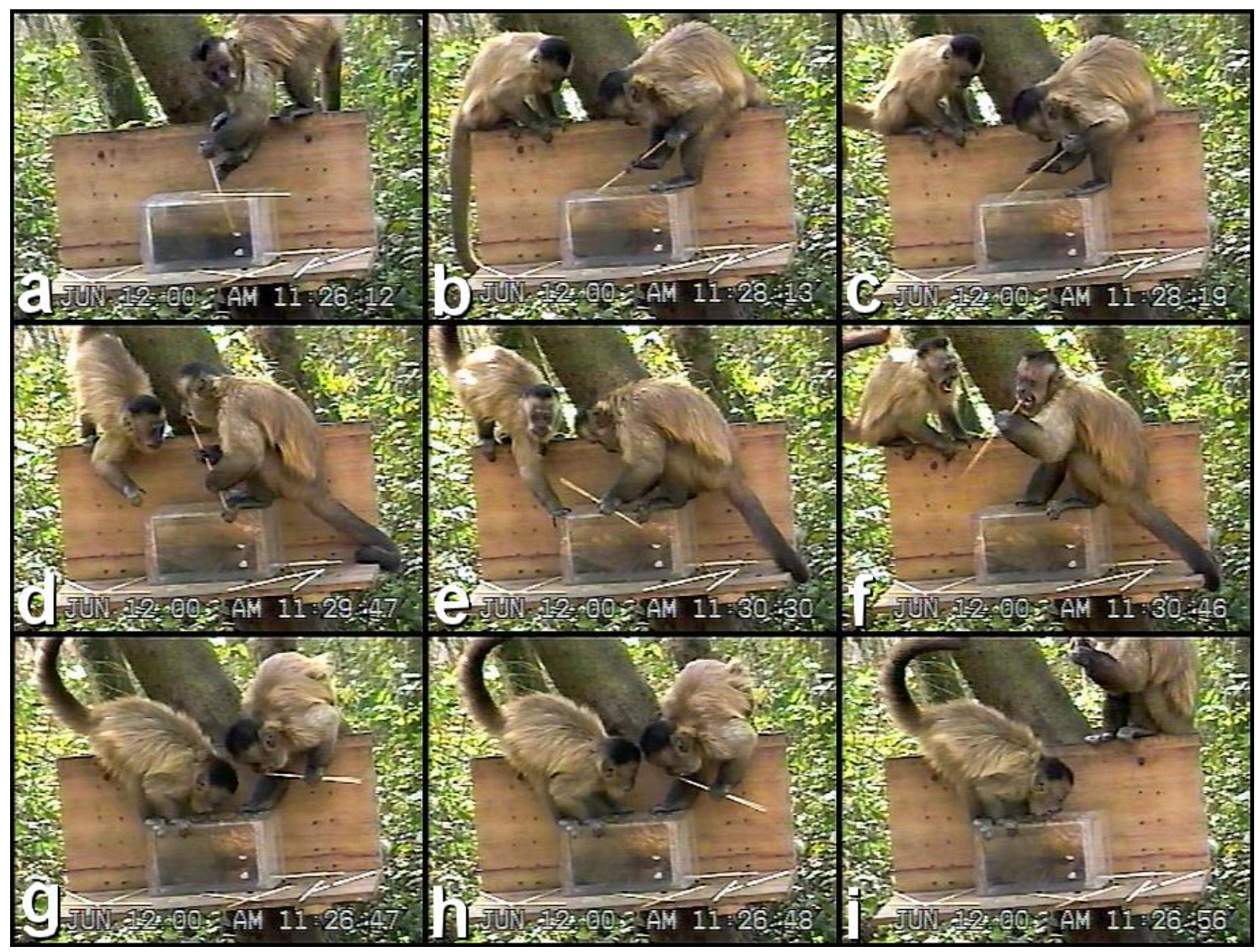

Figura 36. Quinzinho e "scrounger" no aparato experimental (vídeo C. Aquino). 
Cinco indivíduos chegaram a utilizar adequadamente as varetas como sondas, mas no caso de dois infantes, apenas em uma ou duas ocasiões ${ }^{49}$. Por outro lado, dois juvenis (Quinzinho e Pedro) e um macho adulto (Suspeito) se tornaram bastante proficientes no uso destas ferramentas ${ }^{50}$, utilizando-as, respectivamente, em 1429, 581 e 753 introduções bem-sucedidas na extração de melado.

Na Fase 4 (23 sessões), interrompemos o fornecimento de varetas, mas Quinzinho, Pedro e Suspeito continuaram, por algum tempo, localizando nas imediações e utilizando varetas remanescentes de sessões passadas (apesar dos nossos esforços em removê-las); apenas o juvenil Quinzinho e o macho adulto Suspeito produziram suas próprias sondas, utilizando gravetos naturalmente disponíveis (Aquino \& Ottoni 2001).

Não verificamos sinais de aprendizagem socialmente enviesada além de um efeito geral de "local enhancement" com relação à plataforma. Como no estudo original, alguns observadores, quando mais jovens e relativamente tolerados, tornaram-se "scroungers". Os dois infantes que chegaram a usar as varetas não observaram seu uso proficiente por outros indivíduos e, dos 21 indivíduos que não utilizaram as varetas como sondas, 8 tiveram oportunidade de observá-las em uso. Dos três macacos que utilizaram as varetas intensivamente, dois (o juvenil Pedro e o adulto Suspeito) o fizeram após observar seu uso - no caso de Suspeito, pouco depois da observação e com uma freqüência inicial já bastante elevada. Quinzinho, o primeiro a utilizar as varetas sistematicamente, o fez em uma das sessões em que havia varetas previamente introduzidas nos orifícios (este também foi o caso dos 2 episódios do infante Lobato).

\footnotetext{
${ }^{49}$ Lobato nas sessões 31 e 33, Frank na sessão 53 da Fase 3.

${ }^{50}$ Quinzinho a partir da sessão 38, Pedro a partir da sessão 55 e Suspeito, a partir da sessão 77 (a última) da Fase 3.
} 


\subsection{Intervenções experimentais no uso de ferramentas para a quebra de frutos encapsulados}

Uma vez descrito o comportamento espontâneo de uso de pedras como ferramentas, sua demografia e sua ontogenia - e tendo sido iniciados os estudos naturalísticos com populações selvagens, realizamos, pela primeira vez, algumas intervenções experimentais na quebra de cocos pelo grupo da Área de Preservação do PET. Não se tratou de "experimentos" no sentido estrito do termo mas, antes, de intervenções (relativamente) controladas no ambiente "natural" dos sujeitos, para criar determinados problemas para os sujeitos (como a necessidade de escolher ou transportar as ferramentas ou de explorar um recurso novo).

\subsubsection{Introdução de frutos não-familiares}

O primeiro "experimento" (Falótico 2006) envolveu a disponibilização de uma espécie de coco com a qual os macacos do PET não estavam familiarizados, com o objetivo de examinar a disseminação do uso desse fruto no grupo, sob a inspiração de um estudo relatado por Matsuzawa (1994) e Biro et al (2003) com chimpanzés selvagens habituados em Bossou (Guiné). No "laboratório de campo" ali estabelecido, onde a disponibilidade de pedras e de cocos da palmeira Elaeis guineensis era controlada pelos experimentadores, foram fornecidas outras espécies de cocos (Coula edulis) com os quais os sujeitos não tinham tido contato prévio, mas que eram consumidas por grupos em localidades próximas. Apenas uma fêmea, supostamente imigrante de um destes grupos vizinhos, tentou quebrá-los de imediato. Alguns juvenis que a observaram passaram a quebrar estes cocos rapidamente, mas 0 comportamento não se propagou para os adultos do grupo de imediato, talvez porque estes fossem menos neofílicos ou em função de barreiras sociais à difusão de comportamentos de jovens para adultos, como as que percebemos entre macacos-prego no PET - seja nos experimentos com palitos como sondas (Perondi, Ottoni \& Izar 1995, Aquino \& Ottoni 2001) ou nos padrões etários de observação da quebra de cocos - e de modo análogo ao observado 
na difusão de novos comportamentos entre os macacos japoneses (Huffman 1984).

Em nosso experimento, em 222 sessões (duas por semana) ao longo de 14 meses (agosto de 2003 a outubro de 2004), foram disponibilizados para os macacos, junto às "bigornas" experimentais (duas lajotas sextavadas de cimento; Figura 37) cocos de indaiá (Attalea dubia), não naturalmente disponíveis no local e bem mais duros e maiores que os cocos de jerivá (Syagrus romanzoffiana) costumeiramente quebrados e consumidos pelos macacos-prego ${ }^{51}$.

Após uma fase inicial de habituação, tiveram início as sessões experimentais. Cada sessão, que se iniciava com a chegada de um indivíduo ao sítio de quebra experimental, era registrada em vídeo para posterior análise de uma série de aspectos da atividade manipulatória do individuo focal e dos eventuais observadores coespecíficos.

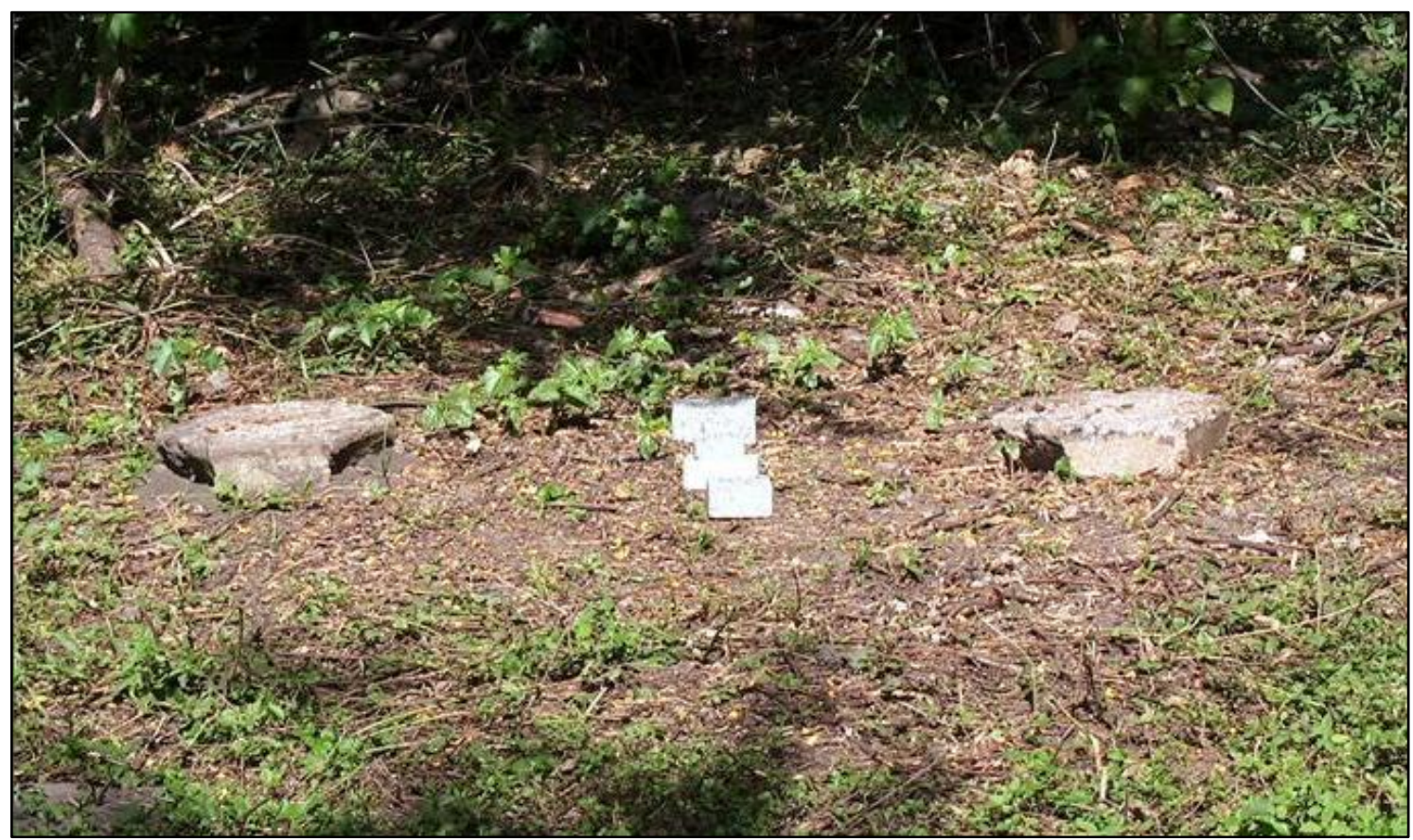

Figura 37. Sítio experimental (com os “martelos” do segundo experimento) (foto T. Falótico).

Numa primeira etapa, o macho adulto Medeiros, que já havia se mostrado extremamente proficiente na quebra de cocos de jerivá, foi o visitante

\footnotetext{
${ }^{51}$ Outras alternativas foram testadas, como castanhas-do-pará, mas os macacos eram capazes de abri-las sem o uso de ferramentas (para maiores detalhes sobre outros aspectos examinados no comportamento dos sujeitos, v. Falótico 2006).
} 
mais constante, quebrando os cocos de indaiá sem hesitação (como Medeiros esgotava completamente este recurso, foi feita uma pausa de 2 meses no experimento, em maio de 2004, na expectativa de que ele diminuísse um pouco sua "participação", dando chance aos outros, o que efetivamente aconteceu). Alguns indivíduos, como Medeiros, Químico e Janete, quebraram e consumiram os novos cocos desde o início do experimento. Medeiros já era notório por sua proficiência na quebra de cocos de jerivá, e era um dos indivíduos mais velhos, não nascido no PET e de origem desconhecida (portanto já poderia estar mais familiarizado com outras espécies de cocos); Janete, adulta supostamente nascida no parque, também se destacava por sua proficiência na quebra de jerivá, sem paralelo entre as fêmeas. Já o caso de Químico era diferente, por se tratar de um juvenil nascido no grupo, comprovadamente sem experiência prévia com o indaiá, e por ter sido o primeiro sujeito ativo no experimento - sem, portanto, oportunidade (ou necessidade) de aprendizagem observacional.

Darwin (macho juvenil), Davi, Suspeito (machos adultos), Ana, Vavá e Cisca (fêmeas adultas) sequer pegavam os cocos de indaiá no início, mas posteriormente passaram a examiná-los e, finalmente, quebrá-los. Para Suspeito, Vavá e Cisca, isso aconteceu de forma mais ou menos repentina. Os dois primeiros mudaram seu padrão de comportamento sem terem observado outros quebrando cocos de indaiá ou explorado restos nos sítios. Já Ana, Darwin, Vavá e Cisca passaram a quebrar estes cocos após observarem outros indivíduos. Para estes animais (ao contrário do que se deu com os que quebraram os novos cocos desde o início), a latência para o início da quebra (após pegar o coco) diminuiu gradualmente, talvez indicando uma familiaridade crescente, mas o tempo necessário para a quebra não variou muito, não havendo indicação de um aperfeiçoamento da técnica.

No que se refere à observação por coespecíficos, embora os 3 indivíduos mais observados tenham sido machos adultos, não encontramos uma correlação significativa entre idade e observação; as taxas de observação aparentemente refletiram, em algum grau, a freqüência dos "alvos" potenciais de observação no sítio experimental.

A relativa facilidade na adoção do novo recurso deixou a impressão de que não foi necessário aprender nenhuma técnica nova, mas apenas a 
reconhecer os novos cocos como tal, por simples generalização (individualmente aprendida) a partir dos cocos conhecidos - eventualmente facilitada pela observação de outros, no caso de Ana, Darwin, Vavá e Cisca, ou por efeitos menos diretos de "stimulus/local enhancement", no caso de Químico, Suspeito, Janete e Medeiros.

\subsubsection{Escolha de "martelos" em função do peso e do tamanho}

O simples ato de tomar um objeto do ambiente para utilizá-lo como ferramenta já implica em alguma escolha dentre uma quantidade indefinida de objetos disponíveis no ambiente. O quão "pré-programada" ou passível (ou dependente) de aprendizagem, o quão grosseira ou precisa é essa escolha, ou quanto de planejamento e ajuste prévio às especificidades do problema imediato está por trás dela, é algo a ser investigado caso a caso - mesmo em se tratando de uma mesma espécie, diante de problemas distintos.

Experimentos sobre escolha de varetas para empurrar comida para fora de tubos de diferentes comprimentos (Chappell \& Kacelnik 2002) e diâmetros (Chappell \& Kacelnik 2004) mostraram que os corvos da Nova Caledônia (Corvus moneduloides) são capazes de selecionar ferramentas adequadas na primeira tentativa, aparentemente avaliando o problema visualmente de antemão, ao invés de resolvê-lo por tentativa-e-erro.

Em macacos-prego, Visalberghi (1990) não verificou, numa tarefa similar em alguns aspectos (uso de objetos para empurrar comida para fora de um tubo) a mesma capacidade de escolher prontamente as ferramentas adequadas. Anderson \& Henneman (1994, apud Anderson 1996), por outro lado, observaram macacos-prego cativos escolherem varetas de diâmetro adequado - ou modificar varetas inadequadas, se não houvesse outras disponíveis - para acessar melado dentro de uma caixa com furos.

Nosso segundo experimento examinou as preferências na escolha de "martelos" de pedra de diferentes pesos. Um peso maior do "martelo" pode facilitar a quebra do coco, mas aumenta os custos energéticos da manipulação (e do transporte, se necessário) e as possibilidades de injúria.

O sítio artificial foi o mesmo utilizado no experimento anterior, mas entre as duas "bigornas" foram oferecidos, enfileirados, cinco "martelos" - peças 
quadradas de granito com 2,2 cm de espessura pesando $300 \mathrm{~g}, 600 \mathrm{~g}, 900 \mathrm{~g}$, $1300 \mathrm{~g}$ e $1700 \mathrm{~g}$, cuja posição relativa em cada sessão experimental era determinada por sorteio (Figura 38). 169 sessões (correspondentes a episódios individuais de quebra de cocos) foram realizadas entre agosto de 2003 e agosto de 2004, sendo registrados, em cada uma, entre outras variáveis, 0 "martelo" escolhido e o desempenho do sujeito (sucesso e número de batidas necessário para quebrar um coco de jerivá - disponível ad libitum).

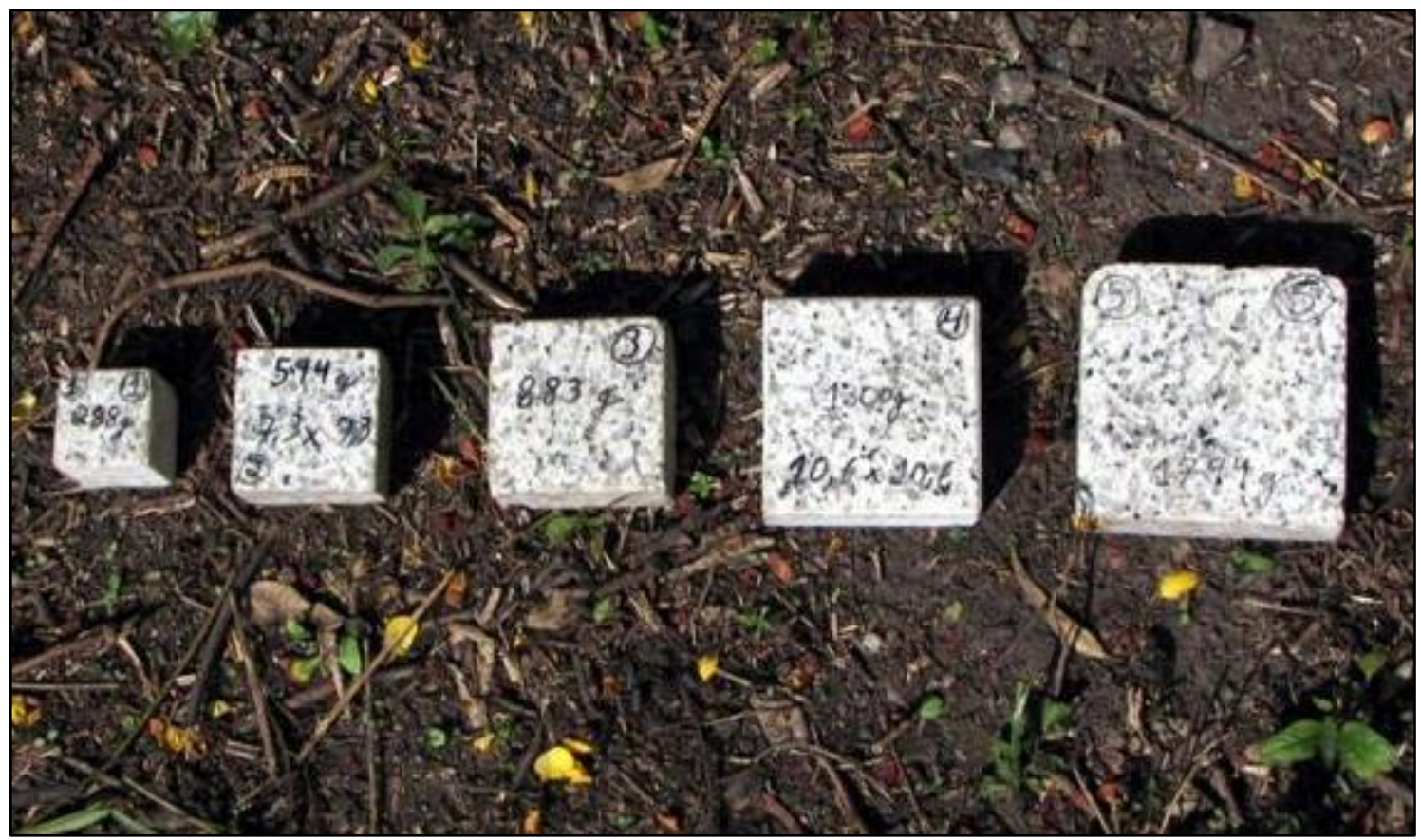

Figura 38. "Martelos" de granito fornecidos junto às bigornas no experimento de escolha, pesando $300 \mathrm{~g}, 600 \mathrm{~g}, 900 \mathrm{~g}, 1300 \mathrm{~g}$ e $1700 \mathrm{~g}$ (foto T. Falótico).

Em 75\% das sessões ocorreu a quebra efetiva de cocos e, se consideradas apenas estas sessões, as freqüências de participação dos indivíduos foram semelhantes às observadas no experimento anterior, exceto pela reduzida participação de Medeiros, que, talvez em função de sua extrema proficiência, seja também extremamente seletivo quanto à ferramenta e não tenha se interessado por nenhum dos nossos "martelos".

No que se refere à posição dos "martelos", dentre os 4 sujeitos cujo número de sessões permitiu a análise estatística individual, apenas para Químico encontramos uma preferência significativa pelos "martelos" nas posições centrais - e uma tendência à significância para Darwin. No entanto, tanto para estes 2 juvenis quanto para os 2 adultos/subadultos cujo 
desempenho foi analisado individualmente, as preferências por peso/tamanho foram significativas.

Os juvenis escolheram significativamente mais o segundo maior "martelo" (1300g) e os adultos, os dois maiores (1300g e 1700g). Uma análise da eficiência do desempenho em função do "martelo" escolhido mostrou que houve uma diferença significativa no número de batidas necessárias para quebrar um coco em função do peso dos "martelos" (ANOVA, p < .0001) e testes post hoc (Tukey HSD \& Bonferroni) os dividiram em dois grupos, sendo os 3 "martelos" mais pesados os mais eficientes (Falótico \& Ottoni 2005).

Embora os adultos tenham escolhido o "martelo" mais pesado com mais freqüência que os juvenis, a distribuição das preferências é similar (Figura 39). O segundo maior martelo, menos eficiente que o maior, foi mais escolhido, talvez em função de um compromisso entre custos conflitantes (maior esforço e/ou riscos de machucar-se com o martelo mais pesado), especialmente pelos juvenis. A maior diferença entre estas sub-amostras etárias está no efeito da posição, que não foi significativo entre os adultos, mas sim entre os juvenis, 0 que sugere uma menor seletividade por estes últimos - que tenderiam, com mais freqüência, a simplesmente pegar o "martelo" mais próximo.
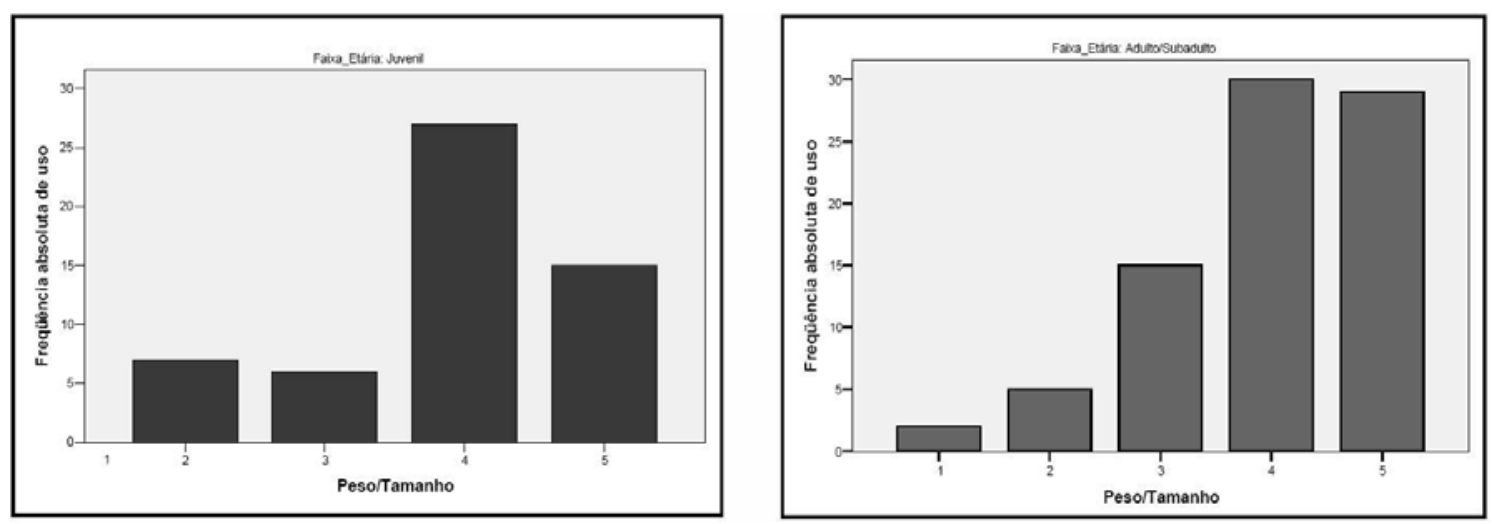

Figura 39. Distribuição das escolhas dos "martelos" em função do peso/tamanho (esquerda: juvenis; direita: adultos/subadultos) (Falótico 2006).

\subsubsection{Transporte de ferramentas}

O terceiro experimento (Falótico \& Ottoni 2007) abordou o transporte das 
ferramentas, verificando se este ocorria quando os "martelos" potenciais se encontravam a $5 \mathrm{~m}$ ou $10 \mathrm{~m}$ do seu local de uso ("bigorna"). O experimento foi realizado em duas fases. Na primeira (100 sessões), os "martelos" (pedras ovaladas/chatas, pesando entre $800 \mathrm{~g}$ e $1800 \mathrm{~g}$, naturalmente disponíveis no parque e previamente utilizadas pelos macacos na quebra de cocos) eram disponibilizados a $5 \mathrm{~m}$ e a $10 \mathrm{~m}$ das "bigornas", junto às quais eram fornecidos cocos de jerivá, no mesmo sítio experimental dos experimentos anteriores. $\mathrm{Na}$ segunda fase (30 sessões), apenas um "martelo" era disponibilizado, a 10m das "bigornas".

Outras pedras utilizáveis foram removidas, num raio de $15 \mathrm{~m}$, mas, durante a primeira fase, os macacos conseguiram, em alguns casos, encontrar algumas remanescentes (além disso, houve transporte de uma pedra até a outra - usada como "bigorna"). Observamos um predomínio de machos (em particular, o Juvenil Darwin) entre os dez animais que realizaram visitas ao sítio com transporte e utilização de ferramentas.

Na primeira fase, houve transporte de "martelos" em $61 \%$ das sessões, por até $14 \mathrm{~m}$, mas na esmagadora maioria (49 dentre 61 eventos de transporte) dos casos, foi transportada a pedra distante $5 \mathrm{~m}$ das "bigornas", enquanto que na segunda fase, com o "martelo" disponibilizado a $10 \mathrm{~m}$ das "bigornas", houve 9 episódios de transporte nas 30 sessões - mas 4 destes por menos de $10 \mathrm{~m}$, em função da utilização de uma "bigorna" naturalmente disponível na mata próxima à clareira. Nesta fase, apenas 4 indivíduos transportaram pedras.

No entanto, os macacos, na maioria dos casos, buscavam primeiro os cocos e os transportavam, havendo ou não quebra subseqüente (em nossas "bigornas" experimentais ou em alguma "bigorna" naturalmente disponível). O transporte de cocos aconteceu em 93.3\% dos episódios de transporte de "martelos" na primeira fase e em todas as sessões da segunda fase, mesmo quando não houve transporte de "martelos" (os cocos eram levados para uma "bigorna" naturalmente disponível ou abandonados). Em todos estes casos, o transporte de cocos foi sempre concomitantemente o dos "martelos", nunca o sucedeu: os animais recolhiam um coco, iam em busca do "martelo" e carregavam ambos até as "bigornas". 


\subsubsection{Escolha de "bigornas"}

Em 2006, colegas da Universidade de Kyoto, durante uma visita ao nosso laboratório, realizaram um experimento sobre a escolha, pelos macacos do PET, de substratos adequados para a quebra de cocos, oferecendo cocos e "martelos" entre duas "bigornas" potenciais, uma adequada (uma das "bigornas" utilizadas nos experimentos conduzidos por Tiago Falótico, v. acima) e outra, não (feita de espuma de borracha macia). Os 7 indivíduos que visitaram o aparato, todos "quebradores" proficientes de cocos, escolheram a "bigorna" adequada na primeira tentativa, em todos os casos (Fujita et al 2007).

\subsection{Escolha de ferramentas adequadas pelos macacos-prego selvagens}

Em função das observações naturalísticas sobre a escolha e transporte de "martelos" pelo grupo aprovisionado da Fazenda Boa Vista (v. Capítulo 5), foi realizado um experimento no qual oito macacos do grupo do Chicão foram expostos à escolha entre 2 (ou 3) "martelos" diferindo quanto ao peso, tamanho e/ou resistência (Visalberghi et al 2009a). Para serem funcionais, os "martelos" precisam ser pesados (seixos pequenos não servem) e resistentes à quebra (o arenito mole também não é apropriado).

Nas duas primeiras condições, os sujeitos escolheram entre pedras similares às naturalmente disponíveis na área, variando quanto à resistência (arenito x siltito) ou ao tamanho e peso (seixo de quartzito grande x pequeno). Cocos eram fornecidos no local e não havia outras pedras disponíveis. Em todos os casos, a pedra funcional foi tocada, transportada e usada significativamente acima do esperado pelo acaso.

Nas três condições seguintes, foram oferecidos "martelos" artificiais, iguais na cor e no material externo, mas variando na forma e no peso. Numa "subversão" da correlação usual entre tamanho e peso, foram disponibilizados para os macacos "martelos" de mesmo tamanho mas peso diferente - onde a escolha não poderia ser feita apenas visualmente (Condição 3), entre 
"martelos" de peso e tamanho conflitantes (grande e leve x pequeno e pesado; Condição 4) e entre três "martelos", sendo um pequeno e leve, outro pequeno e pesado e o último, grande e pesado (Condição 5).

Todos os macacos observados (com a exceção de um na Condição 3) escolheram a pedra funcional numa freqüência acima da esperada pelo acaso, e todos usaram a pedra escolhida (sem trocá-la após o primeiro golpe no coco). Quando malsucedidos (10.3\% das tentativas, 39 em 377), os sujeitos usaram um "martelo" não-funcional em 5 casos e um funcional em 25; apenas em uns poucos casos, o "martelo" escolhido não foi utilizado, porque o sujeito o largou espontaneamente ou por ter sido deslocado pela aproximação de outro indivíduo mais dominante.

As latências da escolha eram curtas, mesmo nos casos em que peso e tamanho estavam dissociados; havendo dicas visuais, os macacos sempre tocaram primeiro pedra funcional; quando não havia esta dica, manipulavam e batiam os "martelos" potenciais (as "batidas" com os dedos para explorar a densidade e as cavidade de objetos são freqüentemente observadas em outros contextos, como na exploração de troncos ou cascas de árvore; v. p.ex., Ottoni \& Mannu 2001).

Em geral, os macacos escolheram, transportaram e usaram, consistente e rapidamente, o "martelo" funcional (quanto ao material e ao peso/tamanho) na primeira tentativa - mesmo quando a distinção não podia ser feita visualmente.

\subsection{Bipedalismo, transporte de ferramentas e planejamento}

O transporte de varetas para a pesca de cupins por chimpanzés é corriqueiro, já que as varetas adequadas em geral não se encontram disponíveis ao lado dos cupinzeiros (McGrew 1974, McBeath \& McGrew 1982); o transporte de "martelos" até "bigornas" fixas também foi observado nesta espécie (Boesch \& Boesch 1984).

Jalles-Filho e colaboradores (2001) questionaram a utilidade dos macacos-prego como modelos do uso de ferramentas pelos primeiros hominíneos, em função de experimentos onde sujeitos cativos não 
transportaram ferramentas de pedra para quebrar uma caixa com comida, se ela estivesse longe das pedras, e transportaram cocos até as pedras, mas não pedras até os $\operatorname{cocos}^{52}$. O transporte dos cocos, por si só, não é uma evidência de planejamento do processamento futuro do item alimentar, já que este se encontra continuamente sob a posse do animal. Entretanto, experimentos mais recentes (Cleveland et al 2004) mostraram que, sob determinadas condições, macacos-prego cativos efetivamente transportam ferramentas: os sujeitos deste estudo levaram parafusos (sondas) até caixas com melado, mesmo quando havia uma barreira visual entre estes elementos. No entanto, os mesmos sujeitos, nas mesmas condições, não transportaram pedras para quebrar nozes, o que, especulam os autores, poderia decorrer dos diferentes custos energéticos envolvidos.

Transportar "martelos" sistematicamente pode ser custoso, mas em condições naturais, "bigornas" duras e planas são via de regra imóveis e menos abundantes - conseqüentemente, os "martelos" têm de ser transportados ao menos uma vez. Talvez as condições de cativeiro tornem os animais mais sensíveis aos custos ou menos motivados; o fato é que, em nossas intervenções experimentais no PET, os macacos prontamente buscavam pedras que servissem como "martelos" e as transportavam bipedalmente (Figura 40) até as "bigornas" quando necessário - ainda que, geralmente, carregando simultaneamente os cocos. O padrão parece ser o mesmo na natureza. Na Serra da Capivara, "martelos" potenciais de pedra, tais como seixos de quartzo, são abundantes, mas na Fazenda Boa Vista, eles têm de ser transportados por uma certa distância quando se estabelece um novo sítio de quebra (naturalmente, a permanência subseqüente dos sítios de quebra limita a necessidade de transporte de "martelos"). E as varetas a serem usadas como sondas na Serra da Capivara (Mannu \& Ottoni 2009) são em geral carregadas até o local de utilização.

\footnotetext{
${ }^{52}$ Mas se tratava de testes numa situação social, onde não faria sentido abandonar o recurso para buscar a ferramenta.
} 


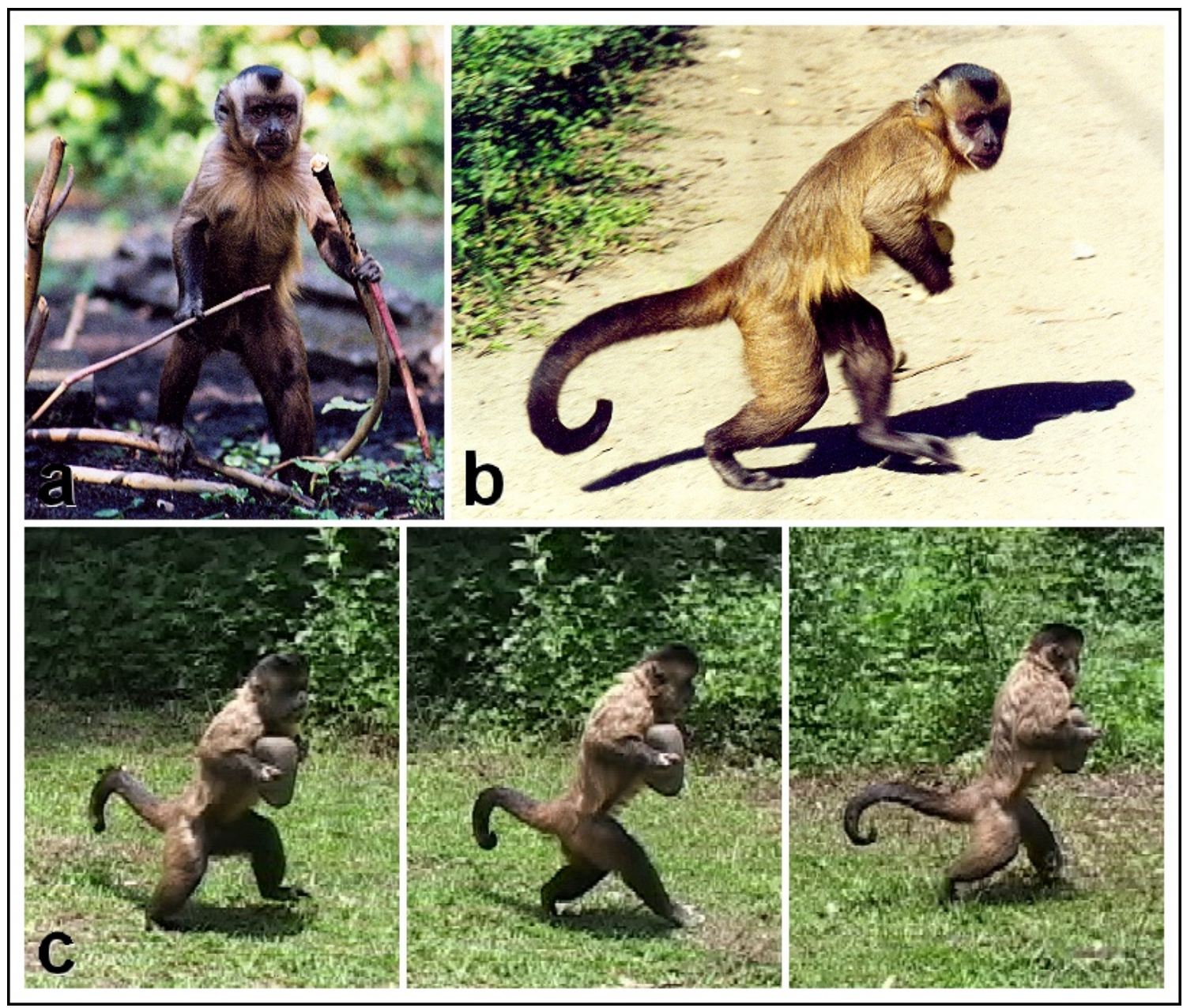

Figura 40. Bipedalismo na manipulação exploratória (a) e no transporte de ferramentas (b,c) (PET; a: foto B.D. Resende; b, c: fotos T. Falótico).

Em um episódio registrado em vídeo por M. Mannu na Serra da Capivara, é possível observar um indivíduo sondando um ninho de abelhas para extrair mel sem sucesso (aparentemente porque a vareta era curta demais), abandonando a ferramenta original e se afastando alguns metros para produzir outra, mais longa, retornando a seguir e retomando a sondagem. Esta seqüência comportamental sugere alguma percepção das deficiências da primeira vareta e, ainda que por um curto intervalo no tempo e no espaço, a capacidade de "planejar" a produção de uma ferramenta mais apropriada para a retomada da tarefa. O transporte dos cocos concomitante com o transporte das ferramentas (nos experimentos sobre transporte de "martelos") também pode indicar algum "planejamento", se constituir uma defesa contra a perda ou usurpação do recurso. Futuros estudos levando em conta possíveis "efeitos de audiência" poderão nos ajudar a entender as motivações e o grau de 
plasticidade por trás deste comportamento. 



\section{Capítulo 7. Mapeando o uso espontâneo de ferramentas na} natureza: tradições comportamentais em macacos-prego?

Como mostra a epígrafe que escolhi para esta tese ${ }^{53}$, a quebra de cocos com 0 auxílio de pedras por macacos-prego selvagens era bem conhecida do folclore brasileiro, embora tenha sido uma "descoberta" tardia para os primatólogos.

Em grande parte, isso pode ser explicado pelo fato de que os estudos de campo de longa duração se concentraram em populações de mata atlântica ou amazônica (Cebus nigritus, C. apella), onde o uso de ferramentas é raro ou ausente, ao contrário do que observamos nas populações de cerrado ou de caatinga (C. libidinosus, C. xanthosternos). E em parte, talvez porque a primatologia mais tradicional, mais interessada em questões morfológicas e taxonômicas, não costuma dar tempo aos seus sujeitos de exibirem qualquer tipo de comportamento...

\subsection{Tradições comportamentais e processos culturais em primatas não-humanos}

O aprovisionamento de macacos japoneses (Macaca fuscata) de vida livre, desencadeou uma série de processos inesperados: o mais notório foi a inovação, introduzida por uma fêmea juvenil, de lavar batatas num riacho, removendo a areia (Kawai 1965). Essa técnica de lavagem do alimento, por sua vez, foi seguida por duas outras inovações: a "lavagem" do trigo fornecido (que bóia, enquanto a areia afunda) e a lavagem das batatas na água salgada

\footnotetext{
53 Agradeço a Eduardo Darvin Ramos da Silva por me chamar a atenção para aquela passagem de Macunaíma, de Mário de Andrade.
} 
do mar, que as "tempera"54. A atividade mais intensa na praia criou condições para outro comportamento inovador: o consumo de peixes (os menores, sem interesse para o consumo humano, que eram abandonados na areia pelos pescadores após a limpeza das redes). Além disso, talvez em função do maior tempo livre decorrente do aprovisionamento, surgiu um comportamento até hoje pouco compreendido, a manipulação de pequenas pedras, sem qualquer finalidade prática aparente (Huffman 1996), originalmente designada, por isso, como "brincadeira" com pedras.

Um dos aspectos mais interessantes na difusão de novos comportamentos são as correlações entre as estruturas sociais da espécie em questão e as possíveis vias de transmissão de cada tipo de inovação. No caso da lavagem das batatas e do trigo pelos macacos japoneses, a inovação se difundiu, basicamente, entre os companheiros de brincadeira de Imo, a jovem fêmea inovadora; o único adulto a aprender com ela foi sua mãe. O consumo de peixes, um item de início estranho aos macacos, foi introduzido por machos periféricos (Watanabe 1989), com acesso mais restrito aos alimentos preferidos $^{55}$, subseqüentemente difundiu-se entre as fêmeas adultas, com quem estes machos compartilhavam o recurso, para só então ser gradualmente adotado pelos imaturos, por influência daquelas fêmeas - suas mães. Já a manipulação de pedras difundiu-se apenas horizontalmente entre infantes e juvenis, até que estes foram-se tornando adultos, quando passou a haver transmissão vertical de mães para seus infantes.

Essa transmissão vertical dos mais velhos para os mais novos passou a ser o padrão para todos estes comportamentos, uma vez estabelecidos na população, caracterizando a fase seguinte, denominada por Huffman (1996) como "Fase da Tradição". Huffman \& Hirata (2003) acrescentaram ao modelo uma "Fase da Inovação", referente ao momento em que o comportamento está totalmente estabelecido na população e começam a surgir variantes inovadoras ou novos usos para os velhos comportamentos.

\footnotetext{
${ }^{54}$ Há questionamentos na literatura quanto a possíveis vieses decorrentes da interação com os humanos: Green 1975 (apud Byrne 1995) apontou uma possível história de condicionamento no aprovisionamento, e Galef [1988] questionou as interpretações sobre aprendizagem socialmente mediada em função da baixa velocidade de difusão.

${ }^{55}$ Corroborando as previsões de Kummer \& Goodall (1985) sobre os indivíduos periféricos como inovadores potenciais ( $v$. adiante).
} 
Embora a primatologia japonesa, ao acompanhar estes processos de difusão e estabelecimento de tradições, já houvesse proposto, há muito, a idéia da existência de processos culturais em primatas não-humanos (Imanishi 1952, apud Huffman 1996; Nishida 1987) foram necessárias mais algumas décadas para que a percepção dicotômica ocidental da relação entre Natureza e Cultura abrisse espaço para uma visão evolucionista dos processos de transmissão social de informação nos animais ${ }^{56}$.

Esta nova percepção resultou, fundamentalmente, da contribuição dos estudos de campo de longa duração, como os de Goodall (1990), que nos mostraram um grau inesperadamente elevado de complexidade na vida social (e na cognição social) dos grandes primatas em geral - e dos chimpanzés em particular (Wrangham et al 1994). E além das "manipulações" de sua vida "política" (também descritas no cativeiro por de Waal, 1982, 1989), estamos hoje familiarizados com toda a gama de objetos modificados e utilizados pelos chimpanzés selvagens.

Assim como acontece com alguns outros comportamentos (v. adiante), muitas das variações nas formas de uso de ferramentas não parecem ser explicáveis apenas em função de diferenças ecológicas ou genéticas entre as populações.

\subsection{Determinantes genéticos, ecológicos e sociais da variabilidade comportamental em animais não-humanos}

A existência de tradições comportamentais em animais não-humanos tem sido proposta em domínios diversos, tais como os da dinâmica e da estrutura social

\footnotetext{
${ }^{56}$ Esta "visão evolucionista" da transmissão social de informações, é importante notar, pode assumir formas bastante distintas: se numa versão sociobiológica extrema (Dawkins 1976) preserva-se uma clara dicotomia entre os "replicadores" (genes ou "memes") e seus "veículos", nos modelos que concebem as relações entre herança genética e a transmissão comportamental de informações como um sistema de "dupla herança" ou de "co-evolução genes-cultura" através de processos de "construção de nicho" (Odling-Smee 1996, Laland, Odling-Smee \& Feldman 2000), as distinções entre evolução e ontogenia ficam menos bem delimitadas, na medida em que as tradições comportamentais, ainda que sejam produto da história evolutiva da espécie, só podem se estabelecer e serem transmitidas se ativamente construídas durante as histórias de desenvolvimento individual e grupal (Avital \& Jablonka 2000).
} 
(de Waal \& Johanowicz 1993, Sapolsky \& Share 2004), dos comportamentos comunicativos (Whiten et al 1999, Rendell \& Whitehead 2001, van Schaik et al 2003, Perry et al 2003), das técnicas de forrageamento e das preferências dietárias (McGrew 1992, van Schaik, Fox \& Sitompul 1996, Whiten et al 1999, Panger et al 2002).

O papel potencial da transmissão social de informação (King 1991) na difusão de determinadas técnicas complexas de forrageamento dos chimpanzés se evidenciou no estudo de McGrew ("A cultura material dos chimpanzés", 1992), onde a comparação dos dados das várias frentes de estudo de campo mostrou um grau de sofisticação técnica e variação interpopulacional (versus homogeneidade intra-grupal) até então inimaginado entre não-humanos, sugerindo, para além de determinantes ecológicos ou padrões comportamentais "inatos" (ou "típicos-da-espécie"), uma função fundamental da aprendizagem socialmente mediada no desenvolvimento cognitivo individual. Estas hipóteses ganharam força diante das evidências de laboratório mostrando que a capacidade de aprendizagem observacional dos chimpanzés vai além do "realce de estímulo" ("stimulus enhancement" - aprendizagem socialmente mediada sobre características do ambiente), incluindo, por exemplo, a capacidade de reproduzir diferentes técnicas seqüenciais de abertura de uma caixa-problema exibidas por diferentes modelos (coespecíficos ou não; Whiten et al 1996), a chamada "imitação ao nível de programa" (Byrne \& Russon, 1998) - um aprendizado sobre o comportamento de outro indivíduo.

Mas a permanência de um determinado padrão comportamental no repertório de um grupo animal é sempre o produto de uma interação entre fatores genéticos e ambientais (sociais ou associais).

Uma determinada característica comportamental pode se manter constante em uma população, ao longo das gerações, em conseqüência de (1) características predominantemente endógenas (transmitidas geneticamente), (2) histórias similares de interação com o ambiente ou (3) pela transmissão inter-individual de padrões comportamentais. Galef (1976) define operacionalmente a transmissão social como envolvendo apenas casos em que a interação social é suficiente para a aquisição do comportamento (mas não necessária - como em certas interações fundamentais para o 
desenvolvimento ontogenético normal da espécie), constituindo uma via alternativa à interação direta entre o indivíduo e o ambiente, e promovendo uma maior homogeneidade comportamental, que se prolonga no tempo para além do período de interação receptor-transmissor.

A grande síntese dos estudos comparativos sobre a variabilidade comportamental entre populações de chimpanzés veio no artigo de Whiten et al (1999), "Cultures in chimpanzees", que mapeou a ocorrência de 65 padrões de comportamento ao longo da área de distribuição natural de Pan troglodytes. Aqui já não se falava, unicamente, de "cultura material", já que a lista de comportamentos não se restringia à utilização de objetos. A meta-análise da literatura se inspirou diretamente no modelo de Galef (v. acima): para sustentar explicações centradas no papel da transmissão social de informação para as diferenças entre grupos e semelhanças intra-grupais, este estudo comparativo tentou descartar as diferenças que dessem margem a explicações baseadas em diferenças genéticas (se observadas em áreas de transição entre as subespécies, sugerindo diferenças "inatas" entre elas) ou em pressões e oportunidades ambientais particulares (relacionadas, por exemplo, à presença ou ausência em cada ambiente dos elementos necessários para a ocorrência do comportamento em questão) que pudessem constituir explicações potencialmente suficientes.

A idéia de tradições sociais entre os pongídeos ganhou força com a descoberta do uso de ferramentas em algumas populações de orangotangos (Pongo pygmaeus; van Schaik, Fox \& Sitompul 1996): apesar da destreza desta espécie no cativeiro, o uso de ferramentas em grupos selvagens foi observado apenas sob condições muito particulares de gregariedade e tolerância social.

As revisões de Whiten et al (1999) e de van Schaik et al (2006) sobre a variabilidade comportamental entre chimpanzés e orangotangos selvagens, respectivamente, nos possibilitaram olhar para o uso de ferramentas nos primatas hominóides sob uma nova perspectiva. Padrões comportamentais não facilmente redutíveis a determinantes genéticos ou ecológicos foram encontrados no uso de ferramentas e em outras técnicas de obtenção e processamento de alimento, nas preferências alimentares, em gestos 
comunicativos e afiliativos $^{57}$, em técnicas de cuidado corporal e, possivelmente, no uso de plantas medicinais.

Foi apontado, no entanto (Fragaszy 2003, Fragaszy \& Perry 2003) que essa abordagem "comparativa" 58 não pode provar ou falsear afirmações de que qualquer comportamento constitua uma tradição, não apenas por ser bastante sujeita a falsos negativos e falsos positivos (v. p. ex. Humle \& Matsuzawa $2002^{59}$ ), mas, antes de mais nada, por não levar em conta o que seria a evidência crítica para se classificar qualquer comportamento como "tradicional": um papel efetivo das influências sociais na aquisição individual do comportamento em questão ${ }^{60}$. O "modelo processual" ("process model") proposto por Fragaszy \& Perry (2003) procura situar as tradições num espaço tridimensional, onde os "eixos" correspondem à sua duração no tempo, à proporção da população exibindo a prática e à contribuição de influências sociais na geração de novos praticantes.

Estas influências sociais, no entanto, são em geral difíceis de medir na pesquisa naturalística - e aqui está a importância das condições controladas fornecidas pelo laboratório ou das condições especialmente favoráveis de observação dos grupos semi-livres.

Os padrões gerais espaço-temporais revelados pelos estudos comparativos podem, apesar das limitações apontadas, ser úteis de diversas formas (van Schaik 2003). Primeiramente, eles nos mostram quais comportamentos são "típicos-da-espécie" e quais são raros ou exclusivamente observados em algumas populações em particular. Esta informação pode guiar

\footnotetext{
${ }^{57}$ Como o hand-clasp grooming (v. Whiten et al 1999).

${ }^{58}$ Ás vezes denominada "etnográfica" (num uso do termo que não é visto com simpatia por muitos antropólogos).

59 Humle \& Matsuzawa (2002) verificaram que a diferença observada entre populações de chimpanzés no comprimento das varetas utilizadas para "pescar" formigas correição, considerada "cultural" no levantamento de Whiten et al (1999) podia ser explicada pelas diferenças entre as espécies de formigas predadas nos diferentes locais (formigas mais velozes requeriam varetas mais longas para serem consumidas com segurança), o que fez esta diferença comportamental "cair no crivo" do modelo (sendo explicada por uma diferença ecológica); isso desencadeou uma ampla revisão do rol de comportamentos previamente classificados, por exclusão, como "culturais" no estudo de 1999.
}

60 Fragaszy \& Perry (2003) definem "tradição" como "uma prática comportamental relativamente duradoura - isto é, repetidamente executada ao longo do tempo - que é compartilhada por dois ou mais membros de um grupo e que depende, em parte, de aprendizagem socialmente facilitada para seu surgimento nos novos praticantes". 
as estratégias investigativas. Em segundo lugar, estes padrões podem ajudar a identificar correlações entre características comportamentais e fatores genéticos ou ecológicos proeminentes, tais como as distribuições de subespécies ou diferenças ambientais marcantes. Às vezes, eles podem também ajudar na detecção de pistas denunciadoras de comportamentos socialmente influenciados, tais como descontinuidades comportamentais associadas a barreiras geográficas que impeçam a difusão inter-grupal (Whiten et al 1999, van Schaik et al 2003). E quando já há evidências, a partir de estudos sobre o desenvolvimento ontogenético, de influências sociais na aprendizagem - como é o caso da pesquisa sobre uso de ferramentas na quebra de cocos pelos macacos-prego - mapear a ocorrência destes comportamentos nas diversas populações pode nos ajudar a formular e testar hipóteses sobre as origens e sobre a dinâmica de difusão de padrões comportamentais particulares.

\subsection{Influência da estrutura e dinâmica social sobre a aprendizagem socialmente enviesada}

Van Schaik, Deaner \& Merrill (1999) formularam a hipótese de que, entre espécies com (1) algum grau de destreza cognitiva e motora e que (2) dependessem de forrageamento extrativo, a disseminação cultural de técnicas complexas de processamento do alimento - em especial, a confecção e o uso de ferramentas - dependeria (3) do grau de tolerância entre os indivíduos do grupo, que determina até que ponto os "aprendizes" potenciais têm acesso à atividade dos "manipuladores" mais proficientes. De modo análogo, CoussiKorbel \& Fragaszy (1995), haviam proposto que o grau típico de proximidade inter-individual tolerado numa dada espécie (que varia em função de relações de idade, parentesco e hierarquia) determina o nível de detalhe em que pode se dar a transmissão social de informação.

Nossos estudos concretizaram a previsão de van Schaik (op.cit.) de que, dadas as referidas pré-condições genéticas, ecológicas e sociais, mesmo entre espécies de primatas do Novo Mundo seria possível a emergência de tradições 
de uso de ferramentas.

Por outro lado, Kummer \& Goodall (1985) enfatizaram a maior oportunidade para a exibição de comportamentos inovadores em animais menos limitados socialmente, tais como aqueles que forrageiam sós ou em pequenos grupos. Como Boinski et al (2003) assinalaram, este é o caso de machos subadultos ou adultos jovens de macacos-prego, menos tolerados - de modo que sua sociedade pode representar um "equilíbrio propício" entre estes fatores, facilitando tanto a inovação quanto a transmissão social.

\subsection{Mapeando os relatos de uso de ferramentas pelos macacos-prego}

Há apenas um único relato anedótico (Boinski 1988) de uso de ferramenta pelos centro-americanos Cebus capucinus, espécie para a qual tradições comportamentais têm sido descritas no que se refere a preferências alimentares (Panger et al 2002) e convenções sociais (Perry et al 2003). E sobre as espécies sem topete da América do Sul, há apenas relatos sobre uso de ferramentas por animais cativos (Urbani 1999).

Das quatro espécies de macacos-prego com topete atualmente reconhecidas (Cebus apella, C. libidinosus, C. nigritus e C. xanthosternos; Fragaszy , Visalberghi \& Fedigan 2004), os principais estudos de longo prazo com populações selvagens, até recentemente, foram realizados com populações de Cebus apella ou C. nigritus, e nos oferecem evidência negativa aparentemente robusta quanto ao uso sistemático de ferramentas (Terborgh 1983, Brown \& Zunino 1990, Peres 1994, Zhang 1995, Di Bitetti 2001, Spironello 2001, Rímoli 2001, Izar 2003,2004, Boinski, com. pessoal): embora algumas formas de manipulação complexa na extração de palmito tenham sido observadas em C. nigritus, na Mata Atlântica (Taira et al 2002), bem como na quebra de cocos (golpeados contra o substrato, sem "martelos") por C. apella amazônicos (Izawa \& Mizuno 1977, Struhsaker \& Leland 1977), não há relatos de uso de ferramentas, conforme definido por Beck (1980), nestas populações (Figura 41). 


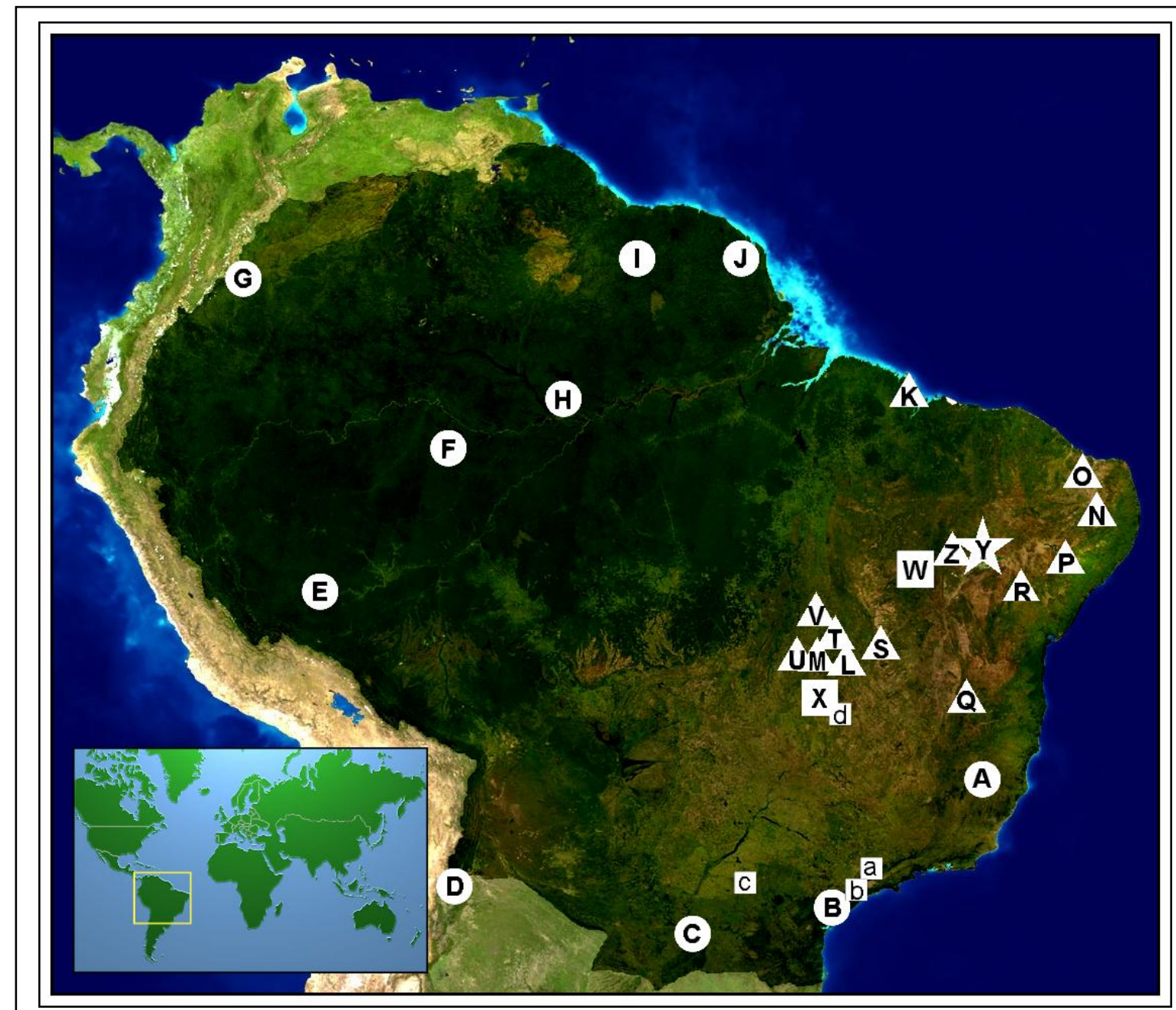

Figura 41. Distribuição de registros de uso espontâneo de ferramentas por macacos-prego selvagens e semi-livres. $\bullet$ : Relatos negativos sobre uso de ferramentas em populações selvagens em estudos de longa duração (mas com evidência anedótica de manipulação complexa no forrageamento). A: Estação Biol. de Caratinga, MG (Rímoli 2001); B: Parque Est. de Carlos Botelho, SP (Izar 2003); C: Parque Nac. Iguazú, Argentina (Di Bitetti 2001); D: Parque Nac. El Rey, Argentina (Brown \& Zunino 1990); E: Estação Biol. de Cocha Cashu, Peru (Terborgh 1983); F: Rio Urucu, AM (Peres 1994); G: La Macarena, Colombia (Izawa \& Mizuno 1977, Struhsaker \& Leland 1977); H: Projeto BDFF, AM (Spironello 2001); I: Raleighvallen, Suriname (S. Boinski, com. pes.); J: Station des Nouragues, Guiana Francesa (Zhang 1995). $\Delta$ : Grupos selvagens com evidências indiretas (sítios de quebra) ou observacões anedóticas de uso de ferramentas na abertura de alimento encapsulado. K: Canelatiua, MA (Fernandes 1991, quebra de ostras no mangue; os relatos restantes se referem à quebra de frutos encapsulados); L: Alto Paraíso, GO (O. Galvão, com. pes.); M: Serra da Mesa, GO (Souza, Mendes \& Silva 2002); N: Desterro do Malta, PB (Langguth \& Alonso 1997); O: Martins, RN (Ferreira, com. pes.); P: Belo Monte, AL (Canale et al 2009); Q: Varzelândia/ Montes Claros, MG (idem); R: Itiúba/ Ibotirama/ Contendas do Sincorá, BA (idem); S: Parque N. da Terra Ronca, GO (Mendes et al, em preparação); T: Minaçu, GO (idem); U: Mara Rosa, GO (Idem); V: Peixe, TO (Idem); Z: Parque N. da Serra das Confusões, PI (T. Falótico, com. pes.). n: Grupos selvagens ou semi-livres com uso costumeiro de pedras como ferramentas na quebra de frutos encapsulados. Quadrados pequenos: grupos semi-livres em parques urbanos. a: Parque Ecol. do Tietê, São Paulo, SP (Ottoni \& Mannu 2001); b: Parque Est. do Jaraguá, São Paulo, SP (Silva, Resende \& Ottoni 2005); c: Parque Mun. Arthur Thomas, Londrina, PR (Rocha, Reis \& Sekiama 1998); d: Parque Água Mineral, Brasilia, DF (E. Visalberghi, com. pes.). Quadrados grandes: grupos selvagens. W: Fazenda Boa Vista, PI (Fragaszy et al 2004) e X: Parque Nac. de Brasília, DF (Waga et al 2006). $\star$ : Grupos selvagens usuários de pedras como ferramentas (para quebrar frutos, escavar solo e cortar plantas), e de varetas como sondas (às vezes combinadas). Y: Parque Nac. da Serra da Capivara, PI (Moura \& Lee 2004, Mannu \& Ottoni 2009). Área escura: distribuição geral dos macacos-prego de topete. A-D: Cebus nigritus; E-K: C. apella; L-P, S-Z: C. libidinosus; Q-R: C. xanthosternos; a-d: híbridos ou incertos (parques urbanos) [de Ottoni \& Izar 2008, atualizado]. 
Foram encontradas evidências indiretas de uso de ferramentas (sítios de quebra) por Cebus xanthosternos da Chapada Diamantina (Bahia; Canale et al 2009) ${ }^{61}$.

Mas a maioria dos relatos de uso de ferramentas por populações selvagens envolve grupos de C. libidinosus vivendo em ambientes abertos, de savana, como o cerrado e a caatinga, que exibem hábitos mais terrestres que outras populações de macacos-prego. Evidências indiretas do uso de pedras na quebra de cocos por $C$. libidinosus selvagens foram relatadas pela primeira vez na literatura primatológica numa população vivendo perto de Desterro do Malta (Paraíba; Langguth \& Alonso, 1977), mas as primeiras observações diretas deste comportamento foram registradas pela equipe do Projeto EthoCebus Fazenda Boa Vista (Gilbués, Piauí; Fragaszy et al 2004), enquanto Moura \& Lee (2004) publicavam os primeiros relatos sobre o uso de ferramentas pelos macacos da Serra da Capivara.

Desde então, é crescente o número de relatos vindos de outras áreas de cerrado no Centro-Oeste brasileiro. A partir destes relatos, nos últimos anos, nossa equipe realizou, em colaboração com Francisco "Dida" Mendes e alunos, uma série de expedições de reconhecimento a localidades no norte de Goiás, que nos mostraram que, ao menos nesta região, o uso de ferramentas na quebra de cocos e outros alimentos encapsulados ${ }^{62}$ é antes a regra que a exceção (Mendes et al, em preparação).

A quebra de alimentos encapsulados com o uso de pedras é, sem dúvida, a forma mais amplamente distribuída de uso de ferramentas, estando presente no "tool-kit" de todos os grupos de macacos-prego que usam ferramentas.

E como relatado no Capítulo 5, as populações de C. libidinosus na Serra da Capivara (são Raimundo Nonato, Piauí) não apenas quebram sementes e frutos encapsulados como o jatobá com o auxílio de pedras, mas exibem outras formas de uso de ferramentas, como o de pedras para cavar o solo em busca

\footnotetext{
${ }^{61} \mathrm{Há}$ um relato de uso de isca para capturar peixes por um cativo desta espécie (M.L.Alves, comunicação pessoal).

${ }^{62}$ No Parque Nacional de Terra Ronca, num ambiente bem mais úmido do que aqueles aonde temos estudado outros grupos de Cebus libidinosus, encontramos muitas evidências indiretas de consumo de moluscos terrestres (conchas quebradas nos sítios de quebra de cocos), como havia sido observado por Massimo Mannu na Serra da Capivara (Mannu \& Ottoni 2009).
} 
de tubérculos ou de varetas como sondas para alcançar ninhos de insetos, pequenos animais ou água em buracos ou rachaduras nas pedras (Moura \& Lee 2004, Mannu \& Ottoni 2009, Falótico \& Ottoni 2009), de modo semelhante ao observado em chimpanzés e em macacos-prego cativos (Westergaard \& Fragaszy 1987). Esta prática usualmente envolve algum grau de preparação ou modificação: as varetas são não apenas destacadas das árvores e redimensionadas, quando necessário, mas algumas são aparadas para remover folhas ou galhos laterais, ou têm a extremidade distal "afinada"63.

Este "tool-kit expandido" favorece a emergência de padrões comportamentais mais complexos, tais como o uso de ferramentas secundárias (Sugiyama 1997) e o uso combinado (seqüencial) de pedras e varetas na exploração de troncos mortos em busca de insetos (Mannu \& Ottoni 2009). E o uso sistemático e diversificado de pedras como ferramentas talvez tenha "propiciado" o surgimento do display de flerte peculiar de algumas fêmeas do grupo da Pedra Furada (Falótico \& Ottoni 2008, v. Capítulo 5).

\subsection{Explicações para a variação entre populações no uso de ferramentas}

A manipulação intensiva, plástica e às vezes complexa de objetos e o uso de substratos duros para a quebra de frutos encapsulados - ainda que não o uso de ferramentas sensu stricto (Beck 1980) parece ser um comportamento "típico-das-espécies" de macacos-prego de topete. $\mathrm{Na}$ busca de causas para o padrão de disseminação do uso de ferramentas no forrageamento em certas populações, as explicações baseadas em determinantes genéticos e/ou ecológicos moldando o comportamento individual poderiam, em princípio, bastar. Entretanto, as evidências oriundas tanto dos experimentos em laboratório quanto dos estudos sobre desenvolvimento em populações semilivres sugerem que não seja assim.

\footnotetext{
${ }^{63}$. O uso costumeiro de varetas como sondas em situação natural só foi, até agora, registrado entre os grupos da Serra da Capivara, mas, naturalmente, os relatos baseados em evidências indiretas poderiam produzir um viés em favor do uso de pedras na quebra de cocos, uma vez que o uso de varetas como sondas não costuma deixar tais evidências.
} 
Os dados disponíveis sobre o uso de ferramentas por grupos selvagens mostram claramente que C. libidinosus e, talvez, C. xanthosternos, são usuários regulares de ferramentas, o que poderia levar a supor que diferenças genéticas explicariam a variação geográfica observada. Entretanto, acreditamos que as diferenças ambientais associadas expliquem melhor estas diferenças, se considerado o conjunto das evidências. A hibridação freqüentemente encontrada nos grupos semi-livres em estudo aparentemente não está correlacionada com quaisquer diferenças perceptíveis nas taxas ou desempenho no uso de ferramentas. Além disso, nenhuma diferença comportamental foi jamais relatada, seja em grupos selvagens ou cativos (inclusive no laboratório), que pudesse ser atribuída a características intrínsecas das diferentes espécies de macacos-prego com topete.

A escassez de alimento em alguns ambientes provavelmente tem um papel importante na exploração de alimentos encapsulados pelos macacosprego, mas parece uma explicação menos provável para a presença ou ausência de uso de ferramentas em uma dada população. Embora a ocorrência de uso de ferramentas em grupos de cerrado e caatinga, juntamente com sua aparente ausência em populações de floresta, tenha levado alguns autores a propor uma explicação baseada neste fator (Moura \& Lee 2004), outras evidências, tais como a ausência de uso de ferramentas em áreas de floresta mesmo durante períodos de escassez alimentar (Izar 2004, Rimoli, com. pessoal), apontam para causas proximais distintas. Afinal de contas, o uso espontâneo e intensivo de ferramentas fora do cativeiro foi inicialmente descrito em grupos semi-livres aprovisionados (Ottoni \& Mannu 2001; Rocha, Reis \& Sekiama 1998; Silva, Resende \& Ottoni 2005).

A forte associação entre fatores como altos níveis de terrestrialidade e baixo risco de predação e o uso de ferramentas, sugerida pelo nosso levantamento, bem como a freqüente adoção de posturas bípedes no transporte de itens alimentares e de ferramentas, nos levam a supor que o grau de terrestrialidade, e não a escassez de comida, seja o preditor mais forte ${ }^{64}$ de uso de ferramentas para acessar frutos encapsulados por um dada população de macacos-prego (Mannu \& Ottoni 2001, Visalberghi et al 2005, 2007). E o

\footnotetext{
${ }^{64}$ Uma condição necessária, talvez, ainda que não suficiente.
} 
uso de pedras para cavar, naturalmente, requer em um grau razoável de terrestrialidade.

Naturalmente, nos referimos aqui às causas "próximas" dos comportamentos em questão. Nosso cenário hipotético, discutido acima, sobre a co-evolução do uso de ferramentas para acessar alimento encapsulado e da tolerância social pressupõe um papel relevante das pressões de um ambiente inóspito, com escassez sazonal de alimentos de fácil acesso, na história evolutiva do uso de ferramentas pelos macacos-prego.

\subsection{Questões e perspectivas}

A quebra de frutos encapsulados com o auxílio de pedras constitui uma tipo de comportamento particularmente propício para o estudo de potenciais tradições comportamentais. Trata-se de uma atividade conspícua em sua execução e em suas conseqüências, o que facilita a observação por coespecíficos - e por pesquisadores. Assim como minha aluna Angela soube do uso de ferramentas por causa dos sons percussivos vindos da mata, os jovens "scroungers" podem saber facilmente quando alguém começa a quebrar cocos.

Os remanescentes da atividade, por sua vez - os sítios de quebra com restos de cocos (com as possibilidades de "scrounging imediato" e "mediato") oferecem uma configuração "facilitadora" que pode propiciar toda uma gama de processos hipotéticos de aprendizagem socialmente enviesada - seja 0 "stimulus enhancement" ("realce de estímulo") o "scaffolding" ou, pelo menos, o reforçamento da visitação (otimizando as condições para uma aprendizagem solitária por tentativa-e-erro).

Enquanto evidências indiretas para o estudo do uso de ferramentas, os sítios de quebra têm sido de grande importância para a nossa pesquisa, e remanescentes de sítios de quebra arcaicos poderão tornar-se objeto de 
futuras investigações comparativas arqueológicas ${ }^{65}$.

Já o uso de varetas como sondas nos parecia colocar alguns problemas, por comparação. Da mesma maneira que não temos, os pesquisadores, como detectar a posteriori com facilidade esta forma de uso de ferramentas (mesmo no curtíssimo prazo), as alterações ambientais decorrentes do uso das varetas não nos pareciam tão potencialmente "informativas" para os outros indivíduos quanto um sítio de quebra de $\operatorname{cocos}^{66}$. Deste modo, as possibilidades de aprendizagem socialmente mediada do uso de varetas como sondas dependeriam mais da observação direta - que seria talvez menos freqüente, já que os episódios do comportamento, em si, aconteceriam em geral de forma mais súbita (menos previsível) e com menos alarde do que a quebra de frutos encapsulados. No entanto, M. Mannu (dados não-publicados) registrou proporcionalmente mais episódios de observação por coespecíficos do uso de varetas do que de observação do uso de pedras. Embora no caso de mel e cera de ninhos de abelhas, algum "scrounging" até fosse possível (mesmo "mediato"), este era bem menos freqüente que no caso da quebra de frutos de jatobá. Talvez aqui encontrássemos, afinal, correlações mais significativas entre observação e proximidade social, dada a natureza mais "oportunista" da observação de uso de varetas (a observação da captura de um inseto ou pequeno vertebrado provavelmente dependeria de já se estar previamente acompanhando o "manipulador"). Poderíamos até especular sobre um maior papel das mães como "modelos" - mas a grande maioria do episódios registrados de uso de varetas foi executada por machos.

Além disso, no que se refere à modificação das varetas antes de seu uso, as exigências em termos atencionais e de oportunidade talvez limitem as possibilidades de mediação social na aprendizagem destes detalhes, que possivelmente só sejam dominados por tentativa-e-erro.

65 Com o propósito de colocar o estudo do uso de ferramentas pelos primatas numa perspectiva de mais ampla, Haslam et al (2009) propõem o estabelecimento de um novo campo interdisciplinar, a "arqueologia primata", voltada para o exame da cultura material presente e passada da Ordem Primates, deixando para trás a separação entre a arqueologia "antropocêntrica" e a etologia de primatas. $\mathrm{Na}$ implementação desta agenda, argumentam estes autores, os resultados mais complexos deverão derivar do estudo do uso de ferramentas líticas por espécies como humanos, chimpanzés, macacos-prego e algumas espécies do gênero Macaca, já que estas práticas deixam registros materiais mais duráveis.

${ }^{66}$ Embora M. Mannu (comunicação pessoal) tenha presenciado um ou dois casos em que uma vareta deixada inserida no local (ninho de abelhas) tivesse sido reutilizada. 
Por outro lado, o uso de sondas não parece depender tanto de hábitos mais terrestres - e é algo que provavelmente beneficiaria mesmo os macacosprego mais arbóreos, já que há buracos em troncos ou ninhos de insetos também nos extratos mais elevados da vegetação - afinal de contas, varetas são as ferramentas mais comuns entre os extremamente arbóreos orangotangos.

Sendo assim, porque praticamente inexistem relatos de episódios de uso de varetas por Cebus nigritus ou $C$. apella em ambientes de mata? Se não reconsiderarmos nossa impressão de que as "espécies" de macacos-prego de topete não sejam comportamental ou cognitivamente tão distintas, então nos resta examinar mais de perto em que medida, por um lado, os diferentes ambientes dificultam ou criam oportunidades para a aprendizagem individual "inovadora" do uso de sondas e, por outro lado, de que maneira estes diferentes ambientes favorecem ou dificultam a atuação de influências sociais sobre o desenvolvimento do comportamento dos jovens, favorecendo ou dificultando, conseqüentemente, a disseminação das inovações e o estabelecimento de tradições comportamentais. Estes efeitos podem estar associados a aspectos físicos (efeitos de fatores como topografia ou densidade da vegetação sobre a visibilidade do comportamento dos coespecíficos) ou sociais (diferenças no tamanho de grupo, na gregariedade ao forragear, na tolerância inter-individual) do "ambiente".

Outra questão central, a ser respondida empiricamente, é até que ponto o "tool-kit" aparentemente mais complexo das populações da Serra da Capivara é exclusivo delas - e se todas, ali, exibem a mesma diversificação no uso de ferramentas.

Investigações preliminares (Falótico, com. pessoal) encontraram indícios de quebra de frutos encapsulados no Parque Nacional da Serra das Confusões (PI), a cerca de $100 \mathrm{~km}$ do Parque Nacional da Serra da Capivara e a "meio caminho" da Fazenda Boa Vista (Figura 42), mas apenas com a habituação e o acompanhamento destas populações nunca estudadas será possível verificar se o seu "tool-kit", é comparável ao dos macacos-prego da Serra da Capivara ou ao dos da Fazenda Boa Vista.

Uma amostragem mais ampla e diversificada das populações de Cebus 
libidinosus nos permitirá, eventualmente, examinar diferentes hipóteses ecológicas e demográficas e testar diferentes modelos para explicar as diferenças na diversificação dos repertórios de uso de ferramentas.

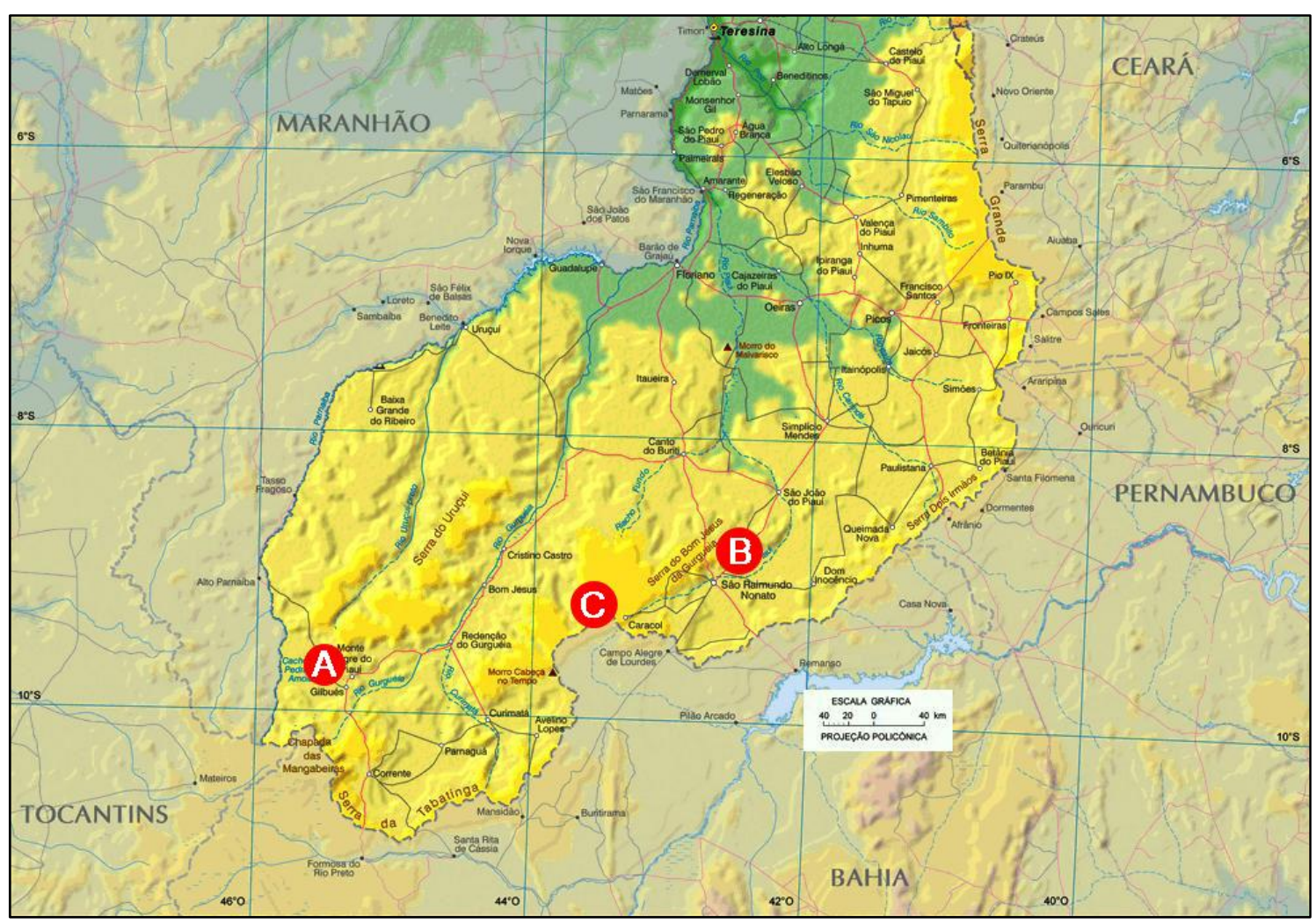

Figura 42. Localização do Parque Nacional da Serra das Confusões (C), entre a Fazenda Boa Vista (A) e a Serra da Capivara (B).

Um possível fator que seria oportuno investigar é o tamanho dos grupos sociais. Muitos grupos da Serra da Capivara possuem até 50 indivíduos, algo um tanto acima dos padrões médios da espécie, o que poderia otimizar as possibilidades de influências sociais na aprendizagem, com mais "modelos" disponíveis - e mais inovadores potenciais.

\subsubsection{Além do uso de ferramentas}

Embora o uso de ferramentas, em geral (e a quebra de cocos, em particular) seja, por todos os motivos expostos, um comportamento estratégico no estudo de tradições comportamentais em animais não-humanos, é importante não perdermos de vista que as tradições podem se estabelecer em qualquer sistema comportamental envolvendo aprendizagem em um contexto social 
favorável e onde os custos da aprendizagem individual independente superem os seus benefícios.

Como mostram os estudos de Susan Perry e colaboradores com Cebus capucinus (Perry 2008), tradições comportamentais podem estar envolvidas na comunicação inter-individual, nos comportamentos afiliativos, em preferências alimentares e técnicas de processamento de alimento. Do mesmo modo, nos deparamos, ao longo das pesquisas com os macacos-prego de topete, com alguns outros padrões comportamentais que poderiam envolver influências sociais e constituir candidatos potenciais no estudo de tradições comportamentais para além do uso de ferramentas.

Certas diferenças entre populações nas técnicas de forrageamento, como no caso da extração do meristema de palmeiras (Taira et al 2002) ou nas interações com outras espécies (Resende et al 2004), merecem ser examinadas sob essa perspectiva. Outro objeto de estudo interessante, neste contexto, seria o comportamento de "anting" (comportamento de "untar-se" com formigas, com o provável propósito de repelir larvas de carrapato; Verderane et al 2007) que observamos entre os macacos-prego da Área de Preservação do Parque Ecológico do Tietêt ${ }^{67}$.

\subsection{Implicações para o entendimento da evolução do uso de ferramentas nos hominíneos}

Embora seja fascinante em si mesma, a pesquisa sobre o uso de ferramentas pelos macacos-prego pode fornecer insights valiosos para os pesquisadores voltados para a evolução tecnológica humana (Ottoni \& Izar 2008).

\footnotetext{
${ }^{67} \mathrm{O}$ "anting" (comportamento originalmente descrito em aves passeriformes, com o aparente propósito de untar as penas com ácido fórmico, talvez para repelir ectoparasitas) foi registrado ao longo de dois anos de observações no PET e, constatou-se, é mais freqüente durante a época do ano em que estão presentes as ninfas do carrapato Amblyomma cajennense. As formigas em questão, Camponotus rufipes, possuem glândulas que secretam ácido fórmico, cujos efeitos repelentes em ninfas de $A$. cajennense foram comprovados em laboratório (Falótico et al 2007). Os testes em laboratório foram desenvolvidos em colaboração com Marcelo Labruna, da FMVZ da USP. Os resultados levaram à abertura de um processo de patente, que recebeu o número de depósito PI 0500987-1 (Auxílio FAPESP \#4/01469-3 NUPLITEC).
} 
Os paleoantropólogos tentam modelar o comportamento dos primeiros hominíneos através de uma abordagem filogenética - usando os pongídeos, especialmente os chimpanzés, como paradigma - ou utilizando os princípios da socioecologia de primatas relacionando dieta, distribuição de alimento e características dos sistemas sociais (Stanford 1999). Dados paleoclimáticos e paleobiológicos ajudam a reconstruir as características do habitat daqueles hominíneos, incluindo a distribuição provável das espécies vegetais e animais que poderiam ter feito parte de sua dieta (Gollop \& Foley 2001). As dietas podem ser inferidas pela comparação de certas características anatômicas, em particular dentes, com os das espécies contemporâneas de primatas, com dietas conhecidas.

Estas linhas de evidências indicam que as dietas dos primeiros australopitecíneos incluíam frutos moles como alimentos preferidos, complementados com frutos encapsulados (cocos, nozes), sementes e órgãos vegetais de armazenamento subterrâneos (Ungar 2004). Há também evidências de que estes itens alimentares fossem extraídos com o auxílio de ferramentas (Alba, Moyà-Solà \& Köhler 2003). Laden \& Wrangham (2005) sugeriram que as diferenças anatômicas entre populações de australopitecíneos "gráceis" e "robustos" poderiam estar associadas a diferentes estratégias de acesso a órgãos de armazenamento subterrâneos. A forte dependência de raízes e tubérculos extraídos com pedras para escavar dos macacos-prego da Serra da Capivara, assim como o recém-descrito uso de ferramentas de madeira com a mesma finalidade por uma população de chimpanzés em Ugalla (Tanzânia) - um dos locais mais secos, abertos e sazonalmente variáveis ocupados pela espécie (Hernandez-Aguilar, Moore \& Pickering 2007), oferecem uma oportunidades únicas de examinar esta questão.

A sofisticação já presente nas ferramentas mais antigas conhecidas na linhagem dos hominíneos, associada à diversidade encontrada nos "tool-kits" dos chimpanzés, levaram ao estabelecimento da noção "parcimoniosa" do surgimento do uso de ferramentas em um ancestral comum de humanos e chimpanzés, tornando estes últimos "modelos" preferenciais para o comportamento dos primeiros hominíneos. Mas a descoberta do uso habitual (e em alguns casos, bastante diversificado) de ferramentas em macacos-prego 
selvagens e algumas espécies do gênero Macaca - associada à ausência destes comportamentos nas populações de bonobos selvagens - nos leva a considerar a possibilidade do surgimento independente de tradições tecnológicas em diferentes linhagens de primatas, e a examinar os papéis relativos da continuidade evolutiva e das convergências adaptativas na formação destas tradições (Haslam et al 2009) - e dos fatores cognitivos, sociais e ecológicos que promovem ou dificultam seu estabelecimento.

Se os macacos-prego (ou outros "parentes menos próximos" dos hominíneos) podem ou não constituir modelos para os estágios mais primitivos do desenvolvimento tecnológico humano, dependerá das questões específicas em exame. De qualquer modo, a emergência do uso de ferramentas entre estes macacos altamente encefalizados e socialmente tolerantes, possivelmente associada ao processo de ocupação de ambientes de savana, bem como o transporte bipedal de ferramentas e alimentos, sugere que estas espécies podem oferecer uma nova perspectiva a respeito dos papéis da filogenia, da ecologia, das estratégias de forrageamento, da terrestrialidade e da tolerância social na evolução da tecnologia, da cognição e da socialidade na linhagem humana. 



\section{Referências Bibliográficas}

Adams-Curtis L \& Fragaszy DM (1995). Influence of a skilled model of conspecific observers in tufted capuchin monkeys (Cebus apella). American Journal of Primatology 37:65-71.

Adams-Curtis LE \& Fragaszy DM (1994). Development of manipulation in capuchin monkeys during the first 6 months. Developmental Psychobiology 27(2):123-136.

Adams-Curtis LE (1990). Conceptual learning in capuchin monkeys. Folia Primatologica 54: 129-137.

Addessi E, Crescimbene L \& Visalberghi E (2007). Do capuchin monkeys (Cebus apella) use tokens as symbols? Proceedings of the Royal Society B 274:2579-2585.

Alba DM, Moyà-Solà S \& Köhler M (2003). Morphological affinities of the Australopithecus afarensis hand on the basis of manual proportions and relative thumb length. Journal of Human Evolution 44:225-254.

Altmann J (1974). Observational study of behaviour: sampling methods. Behavior 49:223-265.

Anderson JR (1990). Use of objects as hammers to open nuts by capuchins monkeys (Cebus apella). Folia Primatologica 54:138-145.

Anderson JR (1996) Chimpanzees and capuchin monkeys: comparative cognition. Pp 23-56 em Russon AE, Bard KA \&Taylor Parker S (eds.),, Reaching Into Thought. Cambridge Univ Press, Cambridge, UK 
Anderson JR, Sallaberry P \& Barbier H (1995). Use of experimenter-given cues during object-choice tasks by capuchin monkeys. Animal Behaviour 49: 201-208.

Andrade M (1984 [1928]). Macunaíma: o herói sem nenhum caráter. Belo Horizonte/Brasília, Itatiaia/Instituto Nacional do Livro/Fundação PróMemória.

Antinucci F (ed.) (1990). Cognitive structure and development in nonhuman primates. Lawrence Erlbaum Associates, Hillsdale, vii+266 pp.

Aquino CMC \& Ottoni EB (2001). Uso induzido de ferramentas por macacosprego (Cebus apella) em condições de semi-liberdade. Anais do XIX Congresso Brasileiro de Etologia:74.

Araújo AJG, Pessis AM, Guérin C, Miranda-Dias CM, Alves C, Salvia ES, Olmos F, Parenti F, Felice GD, Pellerin J, Emperaire L, Chame M, Lage MCSM, Faure M, Guidon N, Medeiros RP, Simões PRG. (1998). Parque Nacional da Serra da Capivara - Piauí - Brasil. S. Raimundo Nonato, Brazil:FUMDHAM and Mission Archéologique et Paléontologique du Piauí. 94 pp.

Avital E \& Jablonka E (2000). Animal traditions - behavioural inheritance in evolution. Cambridge University Press, Cambridge, UK.

Barros RS \& Galvão OF (2002). Estratégias para identificação de características sutis do repertório discriminativo em macacos-prego (Cebus apella). Anais do XX Encontro Anual de Etologia:64-70.

Barros RS, Galvão OF \& Mcllvane WJ (2002). Generalized identity matching-tosample in Cebus apella. The Psychological Record 52:441-460

Beauchamp G \& Kacelnik A (1991). Effects of the knowledge of partners on learning rates in zebra finches Taeniopygia guttata. Animal Behaviour 41:247-253.

Beck BB (1980). Animal tool behavior: the use and manufacture of tools by animals. New York:Garland Press. viii+281 p.

Beckoff M \& Byers J (orgs.) (1998). Animal Play: Evolutionary, Comparative, and Ecological Perspectives. Cambridge University Press, Cambridge. 
Beran MJ (2008). Capuchin monkeys (Cebus apella) succeed in a test of quantity conservation. Animal Cognition 11:109-116.

Biro D, Inoue-Nakamura N, Tonooka R, Yamakoshi G, Sousa C \& Matsuzawa T (2003). Cultural innovation and transmission of tool use in wild chimpanzees: evidence from field experiments. Animal Cognition 6:213223.

Boesch C (1991). Teaching among wild chimpanzees. Animal Behaviour 41:530-532.

Boesch C \& Boesch H (1983). Optimization of nut-cracking with natural hammers by wild chimpanzees. Behaviour 83:265 - 286.

Boesch C \& Boesch H (1984). Mental map in wild chimpanzees: an analysis of hammer transports for nut cracking. Primates 25:160-170.

Boinski S (1988). Use of a club by a wild white-faced capuchin (Cebus capucinus) to attack a venomous snake (Bothrops asper). American Journal of Primatology 14:177-179.

Boinski S (2004). The beats of different drummers: percussion as sexual signalling among brown capuchins at Raleighvallen, Suriname. Folia Primatologica 75 (Supp.):238.

Boinski S, Quatrone RP, Sughrue K, Selvaggi L, Henry M, Stickler CM \& Rose LM (2003). Do brown capuchins socially learn foraging skills?. In Fragaszy DM \& Perry S (eds.) The biology of traditions: models and evidence. Cambridge:Cambridge University Press, p 365-390.

Boinski S, Swing SP, Gross TS \& Davis JK (1999). Environmental enrichment of brown capuchins (Cebus apella): Behavioral and plasma and fecal cortisol measures of effectiveness. American Journal of Primatology 48:49-68, 1999.

Borsari A \& Ottoni EB (2005). Preliminary observations of tool use in captive hyacinth macaws (Anodorhynchus hyacinthinus). Animal Cognition 8:4852.

Brainard MS \& Doupe AJ (2002). What songbirds teach us about learning. Nature 417:351-358. 
Breuer T, Ndoundou-Hockemba M, Fishlock V (2005). First observation of tool use in wild gorillas. PLoS Biology 3(e380):001-003.

Brosnan SF \& de Waal FBM (2003). Monkeys reject unequal pay. Nature 425: 298-299.

Brown AD \& Zunino GE (1990). Dietary variability in Cebus apella in extreme habitats: evidence for adaptability. Folia Primatologica 54:187-195.

Brown AD \& Colillas OJ (1984). Ecologia de Cebus apella. In: Mello, M. T. de (Ed.) A Primatologia no Brasil 1:301-312.

Bugnyar T \& Huber L (1997). Push or pull: an experimental study on imitation in marmosets. Animal Behaviour 54:817-831.

Byrne R (1995). The thinking ape: evolutionary origins of intelligence. Oxford university Press, Oxford, ix+266 pp.

Byrne R \& Whiten A (eds) (1988) Machiavellian Intelligence: Social expertise and evolution of intellect in monkeys, apes, and humans. Oxford University Press, New York.

Byrne RW \& Russon AE (1998). Learning by imitation: a hierarquical approach. Behavioral and Brain Sciences 21(5): 667-684.

Caldwell CA \& Whiten A. (2002). Scrounging facilitates social learning in common marmosets Callithrix jacchus. Animal Behaviour 65:1085-1082.

Call J \& Tomasello M (1995). Use of social information in the problem solving of orangutans (Pongo pymaeus) and human children (Homo sapiens). Journal of Comparative Psychology, 109: 308-320.

Canale GR, Guidorizzi CE, Kierulff MCM \& Gatto C. (2009). First record of tool use by wild populations of the yellow-breasted capuchin monkey (Cebus xanthosternos) and new records for the bearded capuchin ( $C$. libidinosus). American Journal of Primatology 71:1-7.

Carvalho CEG, Izar P \& Ottoni EB (2002). Brincadeira e manipulação exploratória em um grupo de macacos-prego (Cebus apella). Anais do 100 Simpósio Internacional de Iniciação Científica da USP, s/n. 
Carvalho CEG, Resende BD \& Ottoni EB (2001). Estudo piloto sobre brincadeira em macacos-prego (Cebus apella). Anais do XIX Congresso Brasileiro de Etologia:234.

Chappell J \& Kacelnik A (2002). Tool selectivity in a non-primate, the New Caledonian crow (Corvus moneduloides). Animal Cognition 7:121-127.

Chappell J \& Kacelnik A (2004). Selection of tool diameter by New Caledonian crows Corvus moneduloides. Animal Cognition 5:71-78.

Cheney DL \& Seyfarth RM (1990) How monkeys see the world. University of Chicago Press, Chicago, IL..

Chevalier-Skolnikoff S (1989). Spontaneous tool-use and sensorimotor intelligence in Cebus compared with other monkeys and apes. The Behavioral and Brain Sciences, 12: 561 - 627.

Chevalier-Skolnikoff S (1990). Tool use by wild Cebus monkeys at Santa Rosa National Park, Costa Rica. Primates 31(3), 375-383.

Cleveland A, Rocca AM, Wendt EL \& Westergaard GC (2003). Throwing behavior and mass distribution of stone selection in tufted capuchin monkeys (Cebus apella). American Journal of Primatology 61:159-172 (2003).

Cleveland A, Rocca AM, Wendt EL \& Westergaard GC (2004). Transport of tools to food sites in tufted capuchin monkeys (Cebus apella). Animal Cognition 7:193-198.

Coelho CG, Ramos-da-Silva ED \& Ottoni EB (2008). Opportunities for social learning of nut-cracking behaviour by two populations of capuchin monkeys: semi-free ranging (Cebus $s p$.) and wild cerrado population (Cebus libidinosus). Abstracts of the XXII Congress of the International Primatological Society:173.

Coelho CG (2009). Observação por co-específicos e influências sociais na aprendizagem do uso de ferramentas por macacos-prego (Cebus sp) em semi-liberdade. Dissertação de Mestrado não-publicada, Instituto de Psicologia, Universidade de São Paulo, 146 pp. 
Collinge NE (1989). Mirror reactions in a zoo colony of Cebus monkeys. Zoo Biology 8:89-98.

Cooper LR \& Harlow HF (1961). Note on a Cebus monkeys' use of a stick as a weapon. Psychological Reports 8:418.

Coussi-Korbel S \& Fragaszy DM. (1995). On the relation between social dynamics and social learning. Animal Behaviour 50:1441-1553.

Custance D, Whiten A \& Fredman T (1999). Social learning of an artificial fruit task in Capuchin Monkeys (Cebus apella). Journal of Comparative Psychology 113:13-23.

Dasser V (1988). A social concept in Java monkeys. Animal Behaviour 36:225230.

Dawkins R (1976). The selfish gene. Oxford University Press, Oxford, Uk.

Dawson BV \& Foss BM (1965). Observational learning in budgerigars. Animal Behaviour 13:470-474.

de Waal FBM (1982). Chimpanzee politics - power and sex among apes. The Johns Hopkins Univ, Press, Baltimore, 227 pp.

de Waal FBM (1989). Peacemaking among primates. Harvard University Press, Cambridge, xiv+294 pp.

de Waal FBM (1996). Good natured. Harvard University Press, Cambridge, MA. de Waal FBM (2000). Attitudinal reciprocity in food sharing among brown capuchin monkeys. Animal Behaviour 60:253-261.

de Waal FBM \& Berger ML (2000). Payment for labour in monkeys. Nature 404: 563.

de Waal FBM \& Johanowicz D. (1993). Modification of reconciliation behavior through social experience: an experiment with two macaque species. Child Development 64:897-908.

de Waal FBM, Dindo M, Freeman CA, Hall MJ. (2005). The monkey in the mirror: Hardly a stranger. Proceedings of the National Academy of Sciences 102:11140-11147. 
Di Bitetti MS (2001). Home-range use by the tufted capuchin monkey (Cebus apella nigritus) in a subtropical rainforest of Argentina. Journal of Zoology, London 253:33-45.

Dias AC, Custodio Filho A., Franco GADC \& Couto HTZ (1995). Estrutura do componente arbóreo em um trecho de floresta pluvial atlântica secundária - Parque Estadual Carlos Botelho. Revista do Instituto Florestal 7(2): $125-155$.

Dindo M \& de Waal FBM (2007). Partner effects on food consumption in brown capuchin monkeys. American Journal of Primatology 69:1-9.

Dindo M, Whiten A \& de Waal FBM (2009). Social facilitation of exploratory foraging behavior in capuchin monkeys (Cebus apella). American Journal of Primatology 71:419-426.

Doupe AJ \& Kuhl PK (1999). Birdsong and human speech: common themes and mechanisms. Annual Review of Neurosciences 22:567-631.

Dubois M, Gerard JF, Sampaio E, Galvão OF \& Guilhem C (2001). Spatial Facilitation in a probing task in wedge-capped capuchins (Cebus olivaceus). International Journal of Primatology 22(6):993-1005.

Dumas C \& Brunet C (1994). Permanence de l'object chez le singe capucin (Cebus apella): étude des déplacements invisibles. Revue Canadienne de Psychologie Expérimentale 48(3): 341-357.

Erickson CJ, Nowicki S, Dollar L \& Goehring N (1998). Percussive foraging: stimuli for prey location by aye-ayes (Daubentonia madagascariensis). International Journal of Primatology 19(1), 111-122.

Evans TA \& Westergaard GC (2004). Discrimination of functionally appropriate and inappropriate throwing tools by captive tufted capuchins (Cebus apella). Animal Cognition 7:255- 262

Evans TA \& Westergaard GC (2006). Self-control and tool use in tufted capuchin monkeys (Cebus apella). Journal of Comparative Psychology 120 (2):163-166.

Fagen R (1981). Animal play behavior. Oxford University Press, New York. 
Falótico T (2006). Estudo experimental do uso de ferramentas para quebra de frutos encapsulados por macacos-prego (Cebus apella) em semiliberdade. Dissertação de Mestrado não-publicada, Instituto de Psicologia, Universidade de São Paulo, xii+105 pp.

Falótico T, Carvalho CEG, Greco VLG, Izar P \& Ottoni EB (2002). Perseguição de bugio infante (Alouatta sp.) por macacos-prego (Cebus apella): predação ou brincadeira?. Anais do XX Encontro Anual de Etologia: 457.

Falótico T \& Ottoni EB (2005). Experimento de escolha de ferramentas para quebra de cocos por macacos-prego (Cebus apella) em semi-liberdade. Livro de Resumos do XI Congresso Brasileiro de Primatologia:98.

Falótico T \& Ottoni EB (2007). Transporte de ferramentas de pedra por macacos-prego (Cebus apella). Resumos do XII Congresso Brasileiro de Primatologia:s/n.

Falótico T \& Ottoni EB (2008). Aimed stone-throwing by females during courtship in wild capuchin monkeys (Cebus libidinosus). Abstracts of the XXII Congress of the International Primatological Society:284.

Falótico T \& Ottoni EB (2009). Capuchin monkeys of caatinga: many tools for many things. Abstracts of the 46th Annual Meeting of The Animal Behavior Society:72.

Falótico T, Labruna MB, Verderane M, Resende BD, Izar P \& Ottoni EB (2007). Repellent efficacy of formic acid and the abdominal secretion of carpenter ants (Camponotus rufipes) (Hymenoptera: Formicidae), against Amblyomma spp ticks (Acari: Ixodidae). Journal of Medical Entomology 44:718-721.

Fernandes MEB (1991). Tool use and predation of oysters (Crassostrea rhizophorae) by a tufted capuchin, Cebus apella apella, in brackish water mangrove swamp. Primates 32(4):529-531.

Ferreira RG (2003) Coalitions and social dynamics of a semi-free ranging Cebus apella group. Unpublished PhD Thesis, University of Cambridge, UK. 
Ferreira RG, Cavalcanti GC \& Souto A (1996). A utilização espontânea de objeto como instrumento em macaco-prego (Cebus apella). Anais de Etologia 14:385.

Ferreira RG, Resende BD, Mannu M, Ottoni EB \& Izar P. (2002). Bird predation and prey-transfer in brown capuchin monkeys (Cebus apella). Neotropical Primates 10(2):84-89.

Fletcher GE (2008). Attending to the outcome of others: disadvantageous inequity aversion in male capuchin monkeys (Cebus apella). American Journal of Primatology 70:901-905.

Fouts RS (1997). Next of kin. W. Morrow \& Co., NY, xi+420 pp.

Fouts RS, Fouts DH \& Van Cantfort TE (1989). The infant Loulis learns signs from cross-fostered chimpanzees. Ch.8 (280-292) in Gardner RA, Gardner BT \& Van Cantfort TE (eds.), Teaching sign language to chimpanzees. State University of New York Press, N. York, xviii+324 pp.

Fragaszy DM (2003). Making space for traditions. Evolutionary Anthropology 12:61-70.

Fragaszy DM \& Adams-Curtis LE (1991). Generative aspects of manipulation in tufted capuchin monkeys (Cebus apella). Journal of Comparative Psychology 105(4): 387- 397.

Fragaszy DM \& Adams-Curtis LE (1997). Developmental changes in manipulation in tufted capuchins (Cebus apella) from birth through 2 years and their relation to foraging and weaning. Journal of Comparative Psychology 111(2):201-211.

Fragaszy DM, Baer J \& Adams-Curtis L (1991). Behavioral development and maternal care in tufted capuchins (Cebus apella) and squirrel monkeys (Saimiri sciureus) from birth through seven months. Developmental Psychobiology 24(6):375-393.

Fragaszy DM, Izar P, Visalberghi E, Ottoni EB, Oliveira M. (2004). Wild capuchin monkeys use anvils and stone pounding tools. American Journal of Primatology 64:359-366. 
Fragaszy DM, Kennedy E, Murnane A, Menzel C, Brewer G, Johnson-Pynn J \& Hopkins W (2009). Navigating two-dimensional mazes: chimpanzees (Pan troglodytes) and capuchins (Cebus apella ssp.) profit from experience differently. Animal Cognition 12:491-504.

Fragaszy DM \& Perry S (eds.) (2003). The biology of traditions: models and evidence. Cambridge University Press, Cambridge, UK, xvii+456 pp.

Fragaszy DM \& Perry S (2003). Towards a biology of traditions. Pp. 1-32 em Fragaszy DM, Perry S (eds.) The biology of traditions: models and evidence. Cambridge University Press, Cambridge.

Fragaszy DM, Visalberghi E \& Fedigan LM (2004). The complete capuchin the biology of the genus Cebus. Cambridge Univ Press, Cambridge, UK, xiv+342 pp.

Fragaszy DM \& Visalberghi E (1984). Social influences on the acquisition of tool-using behaviors in tufted capuchin monkeys (Cebus apella). Journal of Comparative Psychology 103:159-170.

Fragaszy DM \& Visalberghi E (2001). Recognizing a swan: socially-biased learning. Psychologia 44:82-98.

Fragaszy DM \& Visalberghi E (1990) - Social processes affecting the appearance of innovative behaviors in capuchin monkeys. Folia Primatologica 54:155-165.

Fragaszy DM, Vitale AF \& Ritchie B (1994). Variation among juvenile capuchins in social influences on exploration. American Journal of Primatology 32: 249-260.

Franks NR \& Richardson T (2006). Teaching in tandem-running ants. Nature 439:153.

Freese C \& Oppenheimer J (1981). The capuchin monkeys, genus Cebus. Pp. 331-390 em Coimbra-Filho AF \& Mittermeier RA (eds.), Ecology and Behavior of Neotropical Primates, Vol. 1. Academia Brasileira de Ciências, Rio de Janeiro. 
Fujita K, Kuroshima H, Asai S (2003). How do tufted capuchin monkeys (Cebus apella) understand causality involved in tool use? Journal of Experimental Psychology - Animal Behavior Processes 29:233-242

Fujita K, Tsutsumi S, Morimoto Y, Coelho CG, Falótico T \& Ottoni EB (2007). Substrate choice in nut-cracking behavior of semi-wild tufted capuchin monkeys (Cebus apella). Abstracts of the XXX International Ethological Conference:187-187.

Galdikas B (1982) An unusual instance of tool-use among wild orangutans in Tanjung Puting Reserve, Indonesian Borneo. Primates 23:138-139

Galef BG (1976). Social transmission of acquired behavior: a discussion of tradition and social learning in vertebrates. Advances in the Study of Behavior 6: 77-100.

Galef BG, Manzing LA \& Field RM (1986). Imitation learning in budgerigars: Dawson \& Foss (1965) revisted. Behavioural Processes 13:191-202.

Gallup GGJr (1970). Chimpanzees: self-recognition. Science 167:86-87.

Gardner RA., Gardner BT \& van Cantfort TE (eds.) (1989). Teaching sign language to chimpanzees. State University of New York Press, New York.

Gelman R (1978). Cognitive Development. Annual Review of Psychology 29: 297-332.

Gibson KR (1990). Tool use, imitation and deception in a captive Cebus monkey. Pp. 205-218 em Parker ST \& Gibson KR (eds.), “Language” and intelligence in monkeys and apes: comparative developmental perspectives. Cambridge University Press, New York, xviii+590 pp.

Giraldeau LA \& Lefebvre L (1986). Exchangeable producer and scrounger roles in a captive flock of feral pidgeons: a case for the skill pool effect. Animal Behaviour 34:797-803.

Giraldeau LA \& Lefebrve L (1987). Scrounging prevents cultural transmission of food-finding behaviour in pigeons. Animal Behaviour 35:387-394. 
Gollop P \& Foley RA (2001). Evolutionary geography, habitat availability and species distributions among early African hominids. Pp. 40-58 em Harcourt C (ed.), Monkeys, apes and humans: an evolutionary perspective. Westview Press, London.

Goodall J (1970). Tool-using in primates and other vertebrates. Pp 195-249 em Lehrman DS, Hinde RA \& Shaw E (eds.), Advances in the Study of Behavior 3. Academic Press, New York.

Goodall J (1990). Through a Window. My thirty years with the chimpanzees of Gombe. Houghton Mifflin Co., Boston, 268 pp.

Greco VLG (2003). Uso do solo, bipedalismo e transporte de objetos em macacos-prego (Cebus apella) em semi-liberdade. Monografia de conclusão de curso não-publicada (orientador: Ottoni EB), Universidade Metodista de São Paulo.

Greenfield PM (1991). Language, tools and brain: the ontogeny and phylogeny of hierarchically organized sequential behavior. Behavioral and Brain Sciences 14:531-595.

Gumert MD, Kluck M \& Malaivijitnond S (2009). The physical characteristics and usage patterns of stone axe and pounding hammers used by longtailed macaques in the Andaman Sea region of Thailand. American Journal of Primatology 71:594-608.

Gunst N, Boinski S \& Fragaszy DM (2008). Acquisition of foraging competence in wild brown capuchins (Cebus apella), with special reference to conspecifics' foraging artefacts as an indirect social influence. Behaviour 145:195-229.

Hall KRL \& Schaller GB (1964). Tool-using behavior of the California sea otter. Journal of Mammalogy 45(2):287-298.

Hart BL, Hart LA, McCoy M \& Sarath CR (2001) Cognitive behavior in Asian elephants: use and modification of branches for fly switching. Animal Behaviour 62:839-847 
Haslam M, Hernandez-Aguilar A, Ling V, Carvalho S, de la Torre I, DeStefano A, Du A, Hardy B, Harris J, Marchant L, Matsuzawa T, McGrew W, Mercader J, Mora R, Petraglia M, Roche H, Visalberghi E \& Warren R (2009). Primate archaeology. Nature 460:339-344.

Hauser MD, Kralik J \& Botto-Mahan C (1999) Problem solving and functional design features: experiments on cotton-top tamarins. Animal Behaviour $57: 565-582$

Hauser MD, Pearson H \& Seelig D (2002). Ontogeny of tool use in cottontop tamarins, Saguinus oedipus: innate recognition of functionally relevant features. Animal Behaviour 64:299-311.

Heinrich J (2004). Inequity aversion in capuchins? Nature 428:139.

Hemelrijk C (1990a) Models of, and test for, reciprocity, unidirectionality and other social interaction patterns at group level. Animal Behaviour 39: 1013-1029

Hemelrijk C (1990b) A matrix partial correlation test used in investigations of reciprocity and other social interaction patterns at group level. Journal of Theorethical Biology 143:405-420

Henrich J, Gil-White FJ (2001) The evolution of prestige: freely conferred deference as a mechanism for enhancing the benefits of cultural transmission. Evolution and Human Behavior 22:165-196

Hernandez-Aguilar RA, Moore J \& Pickering TR (2007). Savanna chimpanzees use tools to harvest the underground storage organs of plants. Proceedings of the National Academy of Sciences 104:19210-19213.

Heyes CM (1993) Imitation, culture and cognition. Animal Behaviour, 46, 999 1010.

Heyes CM \& Dawson GR (1990). A demonstration of observational learning in rats using a bidirectional control. The Quarterly Journal of Experimental Psychology 42b:59-71. 
Heyes CM, Dawson GR \& Nokes T (1992). Imitation in rats: initial responding and transfer evidence. The Quarterly Journal of Experimental Psychology 45b:229-240.

Hohmann G, Fruth B (2003) Culture in bonobos? Between-species and withinspecies variation in behavior. Currernt Anthropology 44:563-609.

Horner V \& Whiten A (2005). Causal knowledge and imitation/emulation switching in chimpanzees (Pan troglodytes) and children (Homo sapiens). Animal Cognition 8:164-181.

Huffman MA (1984). Stone-play of Macaca fuscata in Arashiyama B troop: transmission of a non-adaptive behavior. Journal of Human Evolution $13: 725-735$.

Huffman MA (1996). Acquisition of innovative cultural behaviors in non-human primates: a case study of stone handling, a socially transmitted behavior in Japanese macaques. Pp 267-289 em Galef Jr G \& Heyes C (eds.), Social learning in animals: the roots of culture. Academic Press, Orlando, FL.

Huffman MA \& Hirata S (2003). Biological and ecological foundations of primate behavioral tradition. Pp 267-296 em Fragaszy DM, Perry S (eds.), The biology of tradition: models and evidence. Cambridge: Cambridge University Press.

Humle T \& Matsuzawa T (2002). Ant-dipping among the chimpanzees of Bossou, Guinea, and some comparisons with other sites. American Journal of Primatology 58:133-148

Hunt GR \& Gray RD (2004). Direct observations of pandanus-tool manufacture and use by a New Caledonian crow (Corvus moneduloides). Animal Cognition 7:114-120.

Hunt GR (1996). Manufacture and use of hook-tools by New Caledonian crows. Nature 379:249-251.

Inoue-Nakamura N \& Matsuzawa T (1997). Development of stone tool use by wild chimpanzees (Pan troglodytes). Journal of Comparative Psychology, 111(2):159-173. 
Izar P (1994). Análise da estrutura social de um grupo de macacos-prego (Cebus apella) em condições de semi-cativeiro. Dissertação de Mestrado não-publicada, Instituto de Psicologia, Universidade de São Paulo, vii+119 pp.

Izar P (2003). Padrões de uso do habitat por macacos-prego (Cebus apella, PRIMATES, CEBIDAE) na Mata Atlântica. Relatório Científico final apresentado à FAPESP, referente à Bolsa Jovem Pesquisador 00/14590-4, 67 pp.

Izar P (2004). Female social relationships of Cebus apella nigritus in Southeastern Atlantic Forest: an analysis through ecological models of primate social evolution. Behaviour 141:71-99.

Izar P \& Sato T (1997). Influência de abundância alimentar sobre a estrutura de espaçamento interindividual e relações de dominância em um grupo de macacos-prego (Cebus apella). Pp. 250-267 em Ferrari S \& Schneider H (eds.), A Primatologia No Brasil 5, 364 pp.

Izawa K \& Mizuno A (1977). Palm-fruit cracking behavior of wild black-capped capuchin (Cebus apella). Primates 18(4),773-792.

Jalles-Filho E, Grassetto R, da Cunha T \& Salm RA (2001). Transport of tools and mental representation: is capuchin monkey tool behaviour a useful model of Plio-Pleistocene hominid technology? Journal of Human Evolution 40:365-377.

Jerison HJ (1973). Evolution of the Brain and Intelligence. New York: Academic Press.

Johnson CM (2001). Distributed primate cognition: a review. Animal Cognition 4:167-183.

Kathy D, Schick KD, Toth N, Garufi G, Savage-Rumbaugh ES, Rumbaugh \& Sevcik R (1999). Continuing investigations into the stone tool-making and tool-using capabilities of a bonobo (Pan paniscus). Journal of Archaeological Science 26:821-832.

Kawai M (1965). Newly-acquired pré-cultural behavior of the natural troop of Japanese monkeys on Koshima Islet. Primates 6:1-30. 
King BJ (1991). Social information transfer in monkeys, apes and hominids. Yearbook of Physical Anthropology 34: 97-115.

King BJ (1994). The information continuum: evolution of social information transfer in monkeys, apes, and hominids. SAR Press, Santa Fé, xii+166 pp.

Köhler W (1925/1976). The mentality of apes (trad. de E. Winter da $2^{\mathrm{a}}$ ed. rev. 1927). Liveright, New York, vi+336 pp.

Krützen M, Mann J, Heithaus MR, Connor RC, Bejder L \& Sherwin WB (2005). Cultural transmission of tool use in bottlenose dolphins. Proceedings of the National Academy of Sciences 102: 8939-8943.

Kummer H (1967). Tripartite relations in hamadryas baboons. Pp. 63-71 em Altmann SA (ed.), Social communication among primates. University of Chicago Press, Chicago.

Kummer H \& Goodall J. (1985). Conditions of innovative behaviour in primates. Philosophical Transactions of the Royal Soc of London. Series B, Biological Sciences 308:203-214.

Laden G \& Wrangham R (2005). The rise of the hominids as an adaptive shift in fallback foods: plant underground storage organs (USOS) and australopith origins. Journal of Human Evolution 49:482-498.

Laland KN (2004). Social learning strategies. Learning and Behavior 32:4-14

Laland KN \& Kendall JR (2003). What the models say about social learning. Pp. 33-55 em Fragaszy DM \& Perry S (eds.), The Biology of Traditions. Cambridge University Press, Cambridge.

Laland KN, Odling-Smee J \& Feldman MW (2000). Niche construction, biological evolution, and cultural change. Behavioral and Brain Sciences 23:131-175.

Langguth A \& Alonso C (1997). Capuchin monkeys in the Caatinga: tool use and food habits during drought. Neotropical Primates 5(3):77-78. 
Lanjow A (2002). Behavioural adaptation to water scarcity in Tongo chimpanzees. Pp. 52-60 em Marchant L, Boesch C, Hohmann G (eds.), Behavioural Diversity in Chimpanzees and Bonobos. Cambridge University Press, Cambridge.

Lindshield SM \& Rodrigues MA (2009). Tool use in wild spider monkeys (Ateles geoffroyi). Primates 50:269-272.

Lynch JA \& Rímoli J (2000) Demography and social structure of group of Cebus apella nigritus (Goldfuss, 1809, Primates/Cebidae) at Estação Biológica de Caratinga, Minas Gerais. Neotropical Primates 8, 44 - 49.

Malaivijitnond S, Lekprayoon C, Tandavanittj N, Panha S, Cheewatham C \& Hamada Y (2007). Stone-tool usage by thai long-tailed macaques (Macaca fascicularis). American Journal of Primatology 69:227-233.

Mannu M (2002). O uso espontâneo de ferramentas por macacos-prego (Cebus apella) em condições de semi-liberdade: descrição e demografia. Dissertação de Mestrado não-publicada, Instituto de Psicologia, Universidade de S. Paulo, xxi+120 pp.

Mannu M \& Ottoni EB (1996). Observações preliminares das técnicas de forrageamento e uso espontâneo de ferramentas por um grupo de macacos-prego (Cebus apella) em condições de semi-cativeiro. Anais de Etologia 14:384.

Mannu M \& Ottoni EB (1998). Uso espontâneo de ferramentas na quebra de cocos por macacos-prego (Cebus apella): aspectos demográficos. Anais de Etologia 16:179.

Mannu M \& Ottoni EB (1999). Postura e lateralidade na quebra espontânea de cocos por um grupo de macacos-prego (Cebus apella) em condições de semi-cativeiro. Resumos do IX Congresso Brasileiro dePrimatologia:31.

Mannu M \& Ottoni EB (2000). Otimização do forrageamento na quebra espontânea de cocos por um grupo de macacos-prego (Cebus apella). Anais do XVIII Encontro Anual de Etologia:69. 
Mannu M \& Ottoni EB (2001). Preferência por materiais como ferramentas na quebra de cocos por um grupo de macacos-prego. Anais do XIX Congresso Brasileiro de Etologia:75.

Mannu M \& Ottoni EB (2009). The enhanced tool-kit of two groups of wild bearded capuchin monkeys in the Caatinga: tool making, associative use, and secondary tools. American Journal of Primatology 71:242-251.

Martin P \& Bateson P (1993). Measuring behaviour - an introdutory guide (2nd ed.). Cambridge University Press, Cambridge, UK.

Matsuzawa T (1994). Field experiments on use of stone tools by chimpanzees in the wild. Pp. 351-370 en Wrangham RW, McGrew WC, de Waal FBM, \& Heltne PG (Eds.), Chimpanzee Cultures. Harvard University Press Cambridge, MA

McBeath NM \& McGrew WC (1982). Tools used by wild chimpanzees to obtain termites at Mt Assirik, senegal: the influence of habitat. Journal of Human Evolution 11(1):65-72.

McGrew WC (1992) Chimpanzee material culture: implications for human evolution. Cambridge University Press, Cambridge, UK, xvi+277 pp.

McGrew WC (1974). Tool use by wild chimpanzees in feeding upon driver ants. Journal of Human Evolution 3, 501-508.

Melis AP, Hare B \& Tomasello M (2006). Chimpanzees recruit the best collaborators. Science 311:1297-1300.

Mendes FDC, Martins LBR, Pereira JA \& Marquezan RF (2000). Fishing with a bait: a note on behavioural flexibility in Cebus apella. Folia Primatologica 71:350-352.

Mendonça-Furtado O \& Ottoni EB (2005). Uso de ferramentas como enriquecimento ambiental para macacos-prego (Cebus apella) cativos. Caderno de Resumos do XXIII Encontro Anual de Etologia, 59-60.

Mendonça-Furtado O \& Ottoni EB (2008). Learning generalization in problem solving by a blue-fronted parrot (Amazona aestiva). Animal Cognition 11: 719-725. 
Moura ACA \& Lee P (2004). Capuchin stone tool use in caatinga dry forest. Science 306:1909.

Nahallage CAD \& Huffman MA (2007). Age-specific functions of stone handling, a solitary-object play behavior, in japanese macaques (Macaca fuscata). American Journal of Primatology 69:1-15.

Natale F (1989). Causality II: the stick problem. Pp. 121-133 em Antinucci, F. (ed.), Cognitive structure and development in nonhuman primates. Lawrence Erlbaum Associates, Hillsdale, vii+266 pp.

Natale F \& Antinucci F (1989). Stage 6 object-concept and representation. Pp. 97-112 em Antinucci F. (ed.), Cognitive structure and development in nonhuman primates. Lawrence Erlbaum Associates, Hillsdale, vii+266 pp.

Negreiros OC, Custódio Filho A, Dias AC, Franco GADC, Couto HTZ, Vieira MG. \& Moura-Netto BV (1995). Análise estrutural de um trecho de floresta pluvial tropical, Parque Estadual De Carlos Botelho, Núcleo Sete Barras (SP - Brasil). Revista do Instituto Florestal 7:1-33.

Nishida T (1987). Local traditions and cultural transmission. Pp. 462-474 em Smuts BB, Cheney DL, Seyfarth RM, Wrangham RW \& Struhsaker TT (eds.), Primate societies. University of Chicago Press, Chicago, xi+578 pp.

Nishida T \& Nakamura M (1993). Chimpanzee tool use to clear a blocked nasal passage. Folia Primatologica 61:218-220

Oakley KP (1949). Man the Toolmaker. Trustees of the British Museum, London.

Odling-Smee FJ (1996). Niche construction, genetic evolution and cultural change. Behavioural Processes 35:195-205.

Ottoni EB (2000). EthoLog 2.2: a tool for the transcription and timing of behavior observation sessions. Behavior Research Methods, Instruments, \& Computers 32(3):446-449. 
Ottoni EB (2009). A evolução da inteligência e a cognição social. Pp. 54-64 em Yamamoto ME \& Otta E (eds.), Psicologia Evolucionista. Guanabara Koogan, Rio de Janeiro, xiii+219 pp.

Ottoni EB, Falótico T, Coelho CG, Resende BD \& Lacerda FM (2009). Tool use skill acquisition by semifree adult capuchin monkeys. Abstracts of the 46th Annual Meeting of the Animal Behavior Society:130.

Ottoni EB \& Izar P (2008). Capuchin monkey tool use: Overview and implications. Evolutionary Anthropology 17:171-178.

Ottoni EB \& Mannu M (2001). Semifree-ranging tufted capuchins (Cebus apella) spontaneously use tools to crack open nuts. International Journal of Primatology 22:347-358.

Ottoni EB \& Mannu M (2003). Spontaneous use of tools by semi-free-ranging capuchin monkeys. Pp. 440-443 em de Waal FBM \& Tyack P (eds.), Animal social complexity - Intelligence, culture, and individualized societies. Cambridge University Press, Cambridge, MA, 640 pp.

Ottoni EB, Mannu M \& Resende BD (2002). Developmental aspects of the spontaneous use of tools by semifree-ranging brown capuchin monkeys. Abstracts of the XXXIX Animal Behavior Society Meeting:70.

Ottoni EB, Resende BD \& Izar P. (2005). Watching the best nutcrackers: what capuchin monkeys (Cebus apella) know about others' tool using skills. Animal Cognition 8:215-219.

Ottoni EB, Resende BD \& Mannu M (2002). Aspectos ontogenéticos do uso espontâneo de ferramentas por macacos-prego (Cebus apella). Anais do XX Encontro Anual de Etologia:51-56.

Ottoni EB, Resende BD, Mannu M, Aquino CMC, Sestini, AE \& Izar P (2001). Tool use, social structure, and information transfer in capuchin monkeys. Advances in Ethology 36:234.

Panger MA (1988). Object use in free-ranging white-faced capuchins (Cebus capucinus) in Costa Rica. American Journal Of Physical Anthropology 106:311-321. 
Panger M, Perry S, Rose L, Gros-Louis J, Vogel E, Mackinnon KC \& Baker M (2002). Cross-site differences in foraging behavior of white-faced capuchins (Cebus capucinus). American Journal Of Physical Anthropology 119:52-66.

Parker ST \& Gibson KR (1977). Object manipulation, tool use and sensorimotor intelligence as feeding adaptations in Cebus monkeys and great apes. Journal of Human Evolution 6:623-641.

Peres CA (1994). Primate responses to phenological changes in an Amazonian terra firme forest. Biotropica 26:98-112.

Perondi MAM, Izar P \& Ottoni EB (1995). Uso de ferramentas por macacosprego (Cebus apella) em condições de semi-cativeiro: observações preliminares. Anais do XIII Encontro Anual de Etologia:416.

Perry S (2008). Manipulative monkeys - the capuchins of Lomas Barbudal (with JH Manson). Harvard University Press, Cambridge, MA, 358 pp.

Perry S, Baker M, Fedigan L, Gros-Louis J, Jack K, MacKinnon K, Manson J, Panger M, Pyle K \& Rose L (2003). Social conventions in wild whitefaced capuchin monkeys: evidence for traditions in a neotropical primate. Current Anthropology 44:241-268.

Perry S, Barrett HC, Manson JH (2004). White-faced capuchin monkeys show triadic awareness in their choice of allies. Animal Behaviour 67:165-170

Phillips KA (1998). Tool use in wild capuchin monkeys (Cebus albifrons trinitatis). American Journal of Primatology 46:259-261.

Povinelli DJ, Gallup GG, Jr, Eddy TJ, Bierschwale DT, Engstrom MC, Perilloux HK, Toxopeus IB (1997). Chimpanzees recognize themselves in mirrors. Animal Behaviour 53:1083-1088.

Povinelli DJ, Rulf AB, Landau KR, Bierschwale DT (1993). Self-recognition in Chimpanzees (Pan troglodytes): Distribution, ontogeny, and patterns of emergence. Journal of Comparative Psychology 107:347-372. 
Premack D (1988). "Does a chimpanzee have a theory of mind?" revised. Pp. 160 - 179 em Byrne, R. \& Whiten, A., (eds.) Machiavellian Intelligence Social expertise and the evolution of intellect in monkeys, apes, and humans. Clarendon Press, Oxford, xv+413 pp.

Premack D \& Premack AJ (1983). The mind of an ape. Norton, NY, 165 pp.

Premack D \& Woodruff G (1978). Does the chimpanzee have a "Theory of Mind"? Behavioral and Brain Sciences 4:515-526.

Ramos-da-Silva ED (2008). Escolha de alvos coespecíficos na observação do uso de ferramentas por macacos-prego (Cebus libidinosus) selvagens. Dissertação de Mestrado não-publicada, Universidade de São Paulo, viii+87 pp.

Ramos-da-Silva ED \& Ottoni EB (2005). O uso de ferramentas na quebra de cocos por macacos-prego (Cebus apella) em semi-liberdade no Parque Estadual do Jaraguá, SP. Resumos do XXIII Encontro Anual de Etologia:40.

Ramos-da-Silva ED, Resende BD \& Ottoni EB (2005). Técnicas de manipulação de alimentos utilizadas pelo grupo livre de macacos-prego (Cebus apella) do Parque Estadual do Jaraguá: um estudo preliminar. Resumos do XI Congresso Brasileiro de Primatologia:164.

Rasa OAE (1984). A motivational analysis of object play in juvenile dwarf mongooses (Helogale undulata rufula). Animal Behaviour 32:579-589.

Rendell L \& Whitehead H (2001). Culture in whales and dolphins. Behavioral and Brain Sciences 24:309-382.

Resende BD (2004). Ontogenia de comportamentos manipulativos em um grupo de macacos-prego (Cebus apella) em situação de semi-liberdade. Tese de Doutoramento não-publicada, Universidade de São Paulo, vii+112 pp.

Resende BD, Greco VLG, Ottoni EB \& Izar P (2003). Some observations on the predation of small mammals by tufted capuchin monkeys (Cebus apella). Neotropical Primates 11:103-104. 
Resende BD, Izar P \& Ottoni EB (2004). Social play and spatial tolerance in tufted capuchin monkeys (Cebus apella). Revista de Etologia 6(1):55-61.

Resende BD, Mannu M, Izar P \& Ottoni EB (2004). Interaction between capuchin monkeys (Cebus apella) and coatis (Nasua nasua): nonagonistic behaviors and lack of predation. International Journal of Primatology 25(6):1213-1224.

Resende BD \& Ottoni EB (2001). Observational learning in the manipulation of a problem-box by tufted capuchin monkeys (Cebus apella). Revista de Etologia 3(2):89-94.

Resende BD \& Ottoni EB (2002). Brincadeira e aprendizagem do uso de ferramentas em macacos-prego (Cebus apella). Estudos de Psicologia (Natal) 7(1):173-180.

Resende BD, Ottoni EB \& Fragaszy DM (2008). Ontogeny of manipulative behavior and nut-cracking in young tufted capuchin monkeys (Cebus apella): a perception-action perspective. Developmental Science 11:812-824.

Rilling JK \& Insel TR (1999) The primate neocortex in comparative perspective using magnetic resonance imaging. Journal of Human Evolution 37:191223

Rímoli J (2001). Ecologia de macacos-prego (Cebus apella nigritus, Goldfuss, 1809) na Estação Biológica de Caratinga (MG): implicações para a conservação de fragmentos de Mata Atlântica. Tese de Doutorado nãopublicada, Universidade Federal do Pará.

Rocha VJ, Reis NR \& Sekiama ML (1996). Predação de sementes de Syagrus romanzoffiana por Cebus apella através da utilização de "ferramentas", na região de Londrina-PR. Resumos do XXI Congresso Brasileiro de Zoologia:217.

Rocha VJ, Reis NR, Sekiama ML (1998). Uso de ferramentas por Cebus apella (Linnaeus)(Primates, Cebidae) para a obtenção de larvas de Coleoptera que parasitam de sementes de Syagrus romanzoffianum (Cam.) Glassm. (Arecaceae). Revista Brasileira de Zoologia 15:945-950. 
Roma PG, Silberberg A, Huntsberry ME, Christensen CJ, Ruggiero AM \& Suomi SJ (2007). Mark tests for mirror self-recognition in capuchin monkeys (Cebus apella) trained to touch marks. American Journal of Primatology 69:1-12

Roma PG, Silberberg A, Ruggiero AM \& Suomi SJ (2006). Capuchin monkeys, inequity aversion, and the frustration effect. Journal of Comparative Psychology 120 (1):67-73.

Russon AE (2003). Developmental perspectives on great ape traditions. Pp 329-364 em Fragaszy DM \& Perry S (eds.), The biology of traditions: models and evidence. Cambridge University Press, Cambridge.

Russon AE \& Galdikas BMF (1993). Imitation in ex-captive orangutans. Journal of Comparative Psychology 107:147-161.

Santos LR, Miller CT, Hauser MD (2003). Representing tools: how two nonhuman primate species distinguish between the functionally relevant and irrelevant features of a tool. Animal Cognition 6 :269-281

Santos LR, Pearson HM, Spaepen GM, Tsao F \& Hauser MD (2006). Probing the limits of tool competence: Experiments with two non-tool-using species (Cercopithecus aethiops and Saguinus oedipus). Animal Cognition 9:94-109.

Santos LR, Rosati A, Sproul C, Spaulding, B \& Hauser MD (2005). Meansmeans-end tool choice in cotton-top tamarins (Saguinus oedipus): finding the limits on primates' knowledge of tools. Animal Cognition 8:236-246.

Sapolsky RM \& Share LJ (2004). A pacific culture among wild baboons: its emergence and transmission. PLoS Biology 2:534-541.

Sato T (1991). O estudo do comportamento através da teoria dos grafos. Biotemas 4: 96109.

Savage-Rumbaugh S \& Lewin R (1994). Kanzi: the ape at the brink of the human mind. Wiley \& Sons, New York, xvii+299.

Sestini AE \& Ottoni EB (1999). Estrutura social, manipulação de objetos e processos atencionais no infante em macacos-prego (Cebus apella). Anais do XVII Encontro Anual de Etologia:117. 
Siegel S (1975). Estatística não-paramétrica para as ciências do comportamento. McGraw-Hill, São Paulo, xix+350 pp.

Silberberg A, Crescimbene L, Addessi E, Anderson JR \& Visalberghi E (2009) . Does inequity aversion depend on a frustration effect? A test with capuchin monkeys (Cebus apella). Animal Cognition 12:505-509.

Silberberg A, Roma PG, Ruggiero AM \& Suomi SJ (2006). On inequity aversion in nonhuman primates. Journal of Comparative Psychology 120(1):76.

Silk JB (1999). Male bonnet macaques use information about third-party rank relationships to recruit allies. Animal Behaviour 58: 45-51.

Silva FD, Resende BD \& Ottoni EB (2000). Terrestrialidade e bipedalismo em macacos-prego (Cebus apella) em semi-liberdade: observações preliminares. Anais do XVIII Encontro Anual de Etologia:117.

Simons D \& Holtkötter M (1986). Cognitive processes in Cebus monkeys (Cebus apella) when solving problem-box tasks. Folia Primatologica 46: 149-163.

Sinha A (1997). Complex tool manufacture by a wild bonnet macaque, Macaca radiata. Folia Primatologica 68, 23-25.

Slater PJB (2003). Fifty years of bird song research: a case study in animal behaviour. Animal Behaviour 65:633-639.

Souza CA, Mendes FDC \& Silva Jr JN (2002). Utilização de ferramentas por Cebus apella libidinosus de dispersão livre. Anais do $X$ Congresso Brasileiro de Primatologia:89.

Spinozzi G \& Potí P (1989). Causality I: the support problem. Pp. 113-120 em Antinucci $\mathrm{F}$ (ed.), Cognitive structure and development in nonhuman primates. Lawrence Erlbaum Associates, Hillsdale, vii+266 pp.

Spironello WR (2001). The brown capuchin monkey (Cebus apella). Ecology and home range requirements in Central Amazonia. Pp. 271-283 em Bierregaard RO, Gascon Jr C, Lovejoy TE \& Mesquita R (eds.). Lessons from Amazonia: The ecology and conservation of a fragmented forest. Yale University Press, New Haven \& London. 
St Amant R \& Horton TE (2008). Revisiting the definition of animal tool use. Animal Behaviour 75:1199-1208.

Stanford CB (1999). The hunting apes: meat eating and the origins of human behavior. Princeton University Press, Princeton.

Stoinski TS \& Beck B (2001). Spontaneous tool use in captive, freeranging golden lion tamarins (Leontopithecus rosalia rosalia). Primates 42:319326.

Struhsaker TT \& Leland L (1977). Palm-nut smashing by Cebus apella apella in Colombia. Biotropica 9(2):124-126.

Strum SC, Forster D \& Hutchins E (1997). Why Machiavellian intelligence may not be Machiavellian. Pp. 50-85 em Byrne RW \& Whiten A (eds.) Machiavellian intelligence II: extensions and evaluations. Cambridge University Press, Cambridge, UK.

Sugiyama $Y$ (1997). Social traditions and the use of tool-composites by wild chimpanzees. Evolutionary Anthropology 6:23-27.

Taira JT, Verderane MP, Ottoni EB \& Izar P (2002). Exploração das palmeiras Euterpe edulis e Archontophoenix canninghamiana por duas populações de macacos-pregos (Cebus apella). Anais XX Encontro Anual de Etologia:326-326.

Tavares MCH \& Tomaz C (2002). Working memory in capuchin monkeys (Cebus apella). Behavioural Brain Research 131:131-137.

Tebbich S, Taborsky M, Fessl B \& Blomqvist D (2001). Do woodpecker finches acquire tool-use by social learning? Proceedings of the Royal Society $B$ 268:2189-2193.

Terborgh J (1983). Five New World Primates. A study in comparative ecology. Princeton, Princeton University Press, 260 pp.

Terkel J (1996). Cultural transmission of feeding behavior in the black rat (Rattus rattus). Pp. 17-49 em Heyes CM \& Galef Jr BG (eds.), Social learning in animals: the roots of culture. Academic Press, San Diego. 
Thomsen LR, Campbell RD \& Rosell F (2007). Tool-use in a display behaviour by Eurasian beavers (Castor fiber). Animal Cognition 10:477-482.

Tomasello M (1990). Cultural transmission in chimpanzee tool use and signalling? Pp. 274 - 311 in Parker ST \& Gibson KR (eds.) "Language” and intelligence in monkeys and apes: comparative developmental perspectives. Cambridge University Press, New York, xviii+590 pp.

Tomasello M \& Call J (1997). Primate cognition. Oxford University Press, New York, ix+517 pp.

Tomasello M, Savage-Rumbaugh S \& Kruger AC (1993). Imitative learning of actions on objects by children, chimpanzees, and enculturated chimpanzees. Child Development 64:1689-703.

Toth N, Schick KD, Savage-Rumbaugh, ES, Sevcik R \& Rumbaugh DM (1993). Pan the tool maker: investigations into the stone tool-making and toolusing capabilities of a bonobo (Pan paniscus). Journal of Archaeological Science 20:81-91.

Thornton A \& McAuliffe K (2006). Teaching in wild meerkats. Science 313:227229.

Ungar PS (2004). Dental topography and diets of Australopithecus afarensis and early Homo. Journal of Human Evolution 46:605-622

Urbani B (1998). An early report on tool use by neotropical primates. Neotropical Primates 6(4):123-124.

Urbani B (1999). Spontaneous use of tools by wedge-capped capuchin monkeys (Cebus olivaceus). Folia Primatologica 70: 172-174.

Urbani B (2002). Capuchin monkey tool use and Léon Croizat's ideas on the evolution of human behavior. Revista di Biologia/Biology Forum 95:491496.

van Schaik CP (2003). Local traditions in orangutans and chimpanzees: social learning and social tolerance. Pp. 297-328 em Fragaszy DM \& Perry S (eds.), The biology of traditions: models and evidence. Cambridge University Press, Cambridge. 
van Schaik CP, Ancrenaz M, Borgen G, Galdikas B, Knott CD, Singleton I, Suzuki A, Utami SS \& Merril M (2003). Orangutan cultures and the evolution of material culture. Science 299:102-105.

van Schaik CP, Deaner RO \& Merrill MY (1999). The conditions for tool use in primates: implications for the evolution of material culture. Journal of Human Evolution 36: 719-741.

van Schaik CP, Fox EA \& Sitompul AF (1996). Manufacture and use of tools in wild Sumatran orangutans: implications for human evolution. Naturwissenschaften 83:186-188.

van Schaik CP \& Pradhan GR (2003). A model for tool-use traditions in primates: implications for the coevolution of culture and cognition. Journal of Human Evolution 44:645-664.

Verderane MP, Falótico T, Resende BD, Labruna MB, Izar P \& Ottoni EB (2007). Anting in a semifree ranging group of brown capuchin monkeys. International Journal of Primatology 28:47-53.

Verderane MP, Silva, EDR, Spagnoletti N, Fragaszy DM, Visalberghi E, Ottoni EB \& Izar P (2007). Predação de vertebrados por macacos-prego selvagens (Cebus libidinosus) em área de ecótono cerrado/caatinga no Piauí. Resumos do XII Congresso Brasileiro de Primatologia:s/n.

Visalberghi E (1987). Acquisition of nut-cracking behaviour by 2 capuchin monkeys (Cebus apella). Folia Primatologica 49:168-181.

Visalberghi E (1988). Responsiveness to objects in two social groups of tufted capuchin monkeys (Cebus apella). American Journal of Primatology 15: 349-360.

Visalberghi E (1990). Tool use in Cebus. Folia Primatologica 54:146-154.

Visalberghi, E, Addessi, E, Truppa, V, Spagnoletti, N, Ottoni, EB, Izar P \& Fragaszy DM (2009a). Selection of effective stone tools by wild bearded capuchin monkeys. Current Biology 19:213-217.

Visalberghi E, McGrew WC (1997). Cebus meets Pan. International Journal of Primatology 18:677-681. 
Visalberghi E, Spagnoletti N, Ramos-da-Silva ED, Andrade FRD, Ottonl EB, Izar P \& Fragaszy D (2009b). Distribution of potential suitable hammers and transport of hammer tools and nuts by wild capuchin monkeys. Primates, 50, 95-104.

Visalberghi E \& Fragaszy DM (1990a). Do monkeys ape? Pp. 247-273 em Parker ST \& Gibson KR (eds.), "Language” and intelligence in monkeys and apes: comparative developmental perspectives. Cambridge University Press, New York, xviii+590 pp.

Visalberghi E \& Fragaszy DM (1990b). Food-washing behaviour in tufted capuchin monkeys, Cebus apella, and crabeating macaques, Macaca fascicularis. Animal Behaviour 40:829-836.

Visalberghi E \& Fragaszy DM (1995). The behaviour of capuchin monkeys, Cebus apella, with novel food: the role of social context. Animal Behaviour 49:1089-1095.

Visalberghi E, Fragaszy DM, Izar P \& Ottoni EB (2005). Terrestriality and tool use. Science 308:951.

Visalberghi E, Fragaszy D, Ottoni EB, Izar P, Oliveira MG \& Andrade FRD (2007). Characteristics of hammer stones and anvils used by wild bearded capuchin monkeys (Cebus libidinosus) to crack open palm nuts. American Journal of Physical Anthropology 132:426-444.

Visalberghi E, Fragaszy DM \& Savage-Rumbaugh S (1995). Performance in a tool-using task by common chimpanzees (Pan troglodytes), bonobos (Pan paniscus), an orangutan (Pongo pygmaeus), and capuchin monkeys (Cebus apella). Journal of Comparative Psychology 109(1):5260.

Visalberghi E \& Limongelli L (1994). Lack of comprehension of cause-effect relations in tool-using capuchin monkeys (Cebus apella). Journal of Comparative Psychology 108(1):15-22.

Visalberghi E, McGrew WC (1997). Cebus meets Pan. International Journal of Primatology 18:677-681. 
Visalberghi E \& Trinca L (1989). Tool use in capuchin monkeys: distinguishing between performing and understanding. Primates 30(4):511-521.

Waga IC, Dacier AK, Pinga PS \& Tavares, MCH (2006). Spontaneous tool use by wild capuchin monkeys (Cebus libidinosus) in the cerrado. Folia Primatologica 77:337-344.

Walters J (1987). Transition to adulthood. Pp. 358-369 em Smuts BB, Seyfarth RM, Wrangham RM \& Struhsaker TT (eds.), Primate Societies. University of Chicago Press, Chicago.

Watanabe K (1989). Fish: a new addition to the diet of Japanese macaques on Koshima Island. Folia Primatologica 52:124-131.

Watanabe K, Urasopon N \& Malaivijitnond S (2007). Long-tailed macaques use human hair as dental floss. American Journal of Primatology 69:940-944.

Weir AAS, Chappell J \& Kacelnik A (2002) Shaping of hooks in New Caledonian crows. Science 297:281

Westergaard GC (1994). The subsistence technology of capuchins. International Journal of Primatology 15(6): 899-906.

Westergaard GC, Evans TA \& Howell S (2007). Token mediated tool exchange between tufted capuchin monkeys (Cebus apella) Animal Cognition 10:407-414.

Westergaard GC \& Fragaszy DM (1987) The manufacture and use of tools by capuchin monkeys (Cebus apella). Journal of Comparative Psychology 101(2):159-168.

Westergaard GC, Liv C, Chavanne TJ \& Suomi SJ (1998). Token-mediated tool-use by a tufted capuchin monkey (Cebus apella). Animal Cognition 1 :101-106.

Westergaard GC \& Suomi SJ (1993a). Use of a tool-set by capuchins monkeys. Primates 34(4):459-462.

Westergaard GC \& Suomi SJ (1993b). Hand preference in the use of nutcracking tools by tufted capuchin monkeys. Folia Primatologica 61:38-42. 
Westergaard GC \& Suomi SJ (1994a). A simple stone-tool technology in monkeys. Journal of Human Evolution 27:399-404.

Westergaard GC \& Suomi SJ (1994b). The use and modification of bone tools by capuchin monkeys. Current Anthropology 35(1):75-77.

Westergaard GC \& Suomi SJ (1994c). Hierarchical complexity of combinatorial manipulation in capuchin monkeys (Cebus apella). American Journal of Primatology 32:171-176.

Westergaard GC \& Suomi SJ (1994d). Asymmetrical manipulation in the use of tools by tufted capuchin monkeys (Cebus apella). Folia Primatologica 63: 96-98.

Westergaard GC \& Suomi SJ (1994e). The use of probing tools by tufted capuchins (Cebus apella): evidence for increased right-hand preference with age. International Journal of Primatology 15(4):521-529.

Westergaard GC \& Suomi SJ (1994f). Aimed throwing of stones by tufted capuchin monkeys (Cebus apella). Human Evolution 9(4):323-329.

Whiten A, Custance DM, Gomez JC, Teixidor P \& Bard KA (1996). Imitative learning of artificial fruit processing in children (Homo sapiens) and chimpanzees (Pan troglodytes). Journal of Comparative Psychology 110(1):3-14.

Whiten A, Goodall J, McGrew WC, Nishida T, Reynolds V, Sugiyama Y, Tutin CEG, Wrangham RW \& Boesch C (1999). Cultures in chimpanzees. Nature 399:682-685.

Whiten A \& Ham R (1992). On the nature and evolution of imitation in the animal kingdom: reappraisal of a century of research. Advances in the Study of Behavior 21:239-283.

Whiten A, Spiteri A, Horner V, Bonnie KE, Lambeth SP, Schapiro SJ \& de Waal FBM (2007). Transmission of multiple traditions within and between chimpanzee groups. Current Biology 17:1-6.

Wittiger L \& Sunderland-Groves JL (2007). Tool use during display behavior in wild Cross River gorillas. American Journal of Primatology 69:1307-1311. 
Wrangham RW, McGrew WC, de Waal FBM \& Heltne P (eds.) (1994). Chimpanzee Cultures. Harvard University Press, Cambridge, MA, xxiii+424 pp.

Wynne CDL (2004). Fair refusal by capuchin monkeys. Nature 428:140.

Zhang S (1995). Activity and ranging patterns in relation to fruit utilization by brown capuchin monkeys (Cebus apella). International Journal of Primatology 16:489-507. 


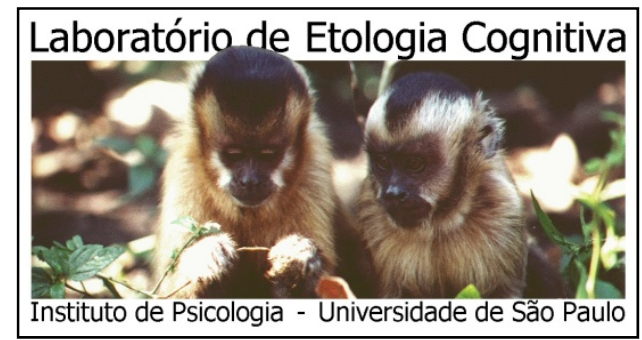

